\title{
Gestão estratégica do design de embalagens: A comunicação visual a serviço da marca
}

\author{
Dissertação de Mestrado para o Programa de Pós- \\ Graduação em Ciências da Comunicação, Área de \\ Concentração Estudos dos Meios e da Produção \\ Mediática, Linha de Pesquisa Comunicação Impressa e \\ Audiovisual, Escola de Comunicações e Artes da \\ Universidade de São Paulo, como exigência parcial para \\ obtenção do Título de Mestre em Ciências da \\ Comunicação, sob a orientação da Prof. Dra. Sandra M. \\ R. de Souza.
}




\title{
Gestão estratégica do design de embalagens: A comunicação visual a serviço da marca
}

\author{
Dissertação de Mestrado para o Programa de Pós- \\ Graduação em Ciências da Comunicação, Área de \\ Concentração Estudos dos Meios e da Produção Mediática, \\ Linha de Pesquisa Comunicação Impressa e Audiovisual, \\ Escola de Comunicações e Artes da Universidade de São \\ Paulo, como exigência parcial para obtenção do Título de \\ Mestre em Ciências da Comunicação, sob a orientação da \\ Prof. Dra. Sandra M. R. de Souza
}

São Paulo 

Dedico esse trabalho à todos que me ajudaram a chegar até aqui, àqueles que tiveram paciência com minha dedicada e exaustiva rotina de estudos e que sentiram minha ausência, justificada pelo ânsia em atingir e superar objetivos:

Ao meu marido querido, Alexandre, que me apoiou durante essa longa caminhada e que sempre acreditou em mim;

Aos meus pais que me ensinaram que só com disciplina e esforço se consegue as coisas na vida;

À minha sogra, pelo carinho e cuidado de mãe e ao meu sogro, estudante apaixonado e mestre entusiasmado;

E à todos os meus amigos, que ficaram por hora, um pouco afastados mas sempre presentes em meu coração. 


\section{Resumo}

"Gestão estratégica do design de embalagens: A comunicação visual a serviço da marca" tem por objetivo resgatar a importância do design de embalagens como mídia fundamental na comunicação de marca, explorar suas potencialidades e limites a partir de uma abordagem estratégica, onde o design ganha um escopo de atuação ampliado não restrito à manipulação de recursos visuais ou a uma função exclusiva do designer, bem como contribuir para um melhor emprego do design de embalagens a partir da conscientização dos profissionais e estudiosos das áreas de marketing, comunicação e design quanto à sua importância, fornecendo subsídios para que esses possam inovar de maneira integrada e competitiva.

Baseada em um estudo exploratório focado no levantamento de fontes literárias, na sistematização de conteúdos, na realização de entrevistas com profissionais envoltos na temática e no estudo de alguns casos, a dissertação aponta para uma nova visão em que a embalagem só é capaz de trabalhar a serviço da marca se for gerida segundo uma mentalidade estratégica de design, suportada por uma abordagem projetual associada aos objetivos de marketing e de planejamento de marca que amplia o raio de atuação do designer e do executivo de marketing.

Afinal, o design de embalagens não se restringe a atividades de senso estético, mas a uma função que implica na gestão de informações, que começa e termina no marketing e que se expressa por meio da comunicação visual. 


\section{Ahstract}

"Strategic packaging design management: the visual communication working for

the brand" aims to rescue the importance of packaging design as a fundamental media in brand communication; to explore main potentialities and limits under an strategic view, where the design's scope is increased being more than visual elements organization or an exclusive designer's task, as well contribute to a better use of packaging design by designers and marketers through a real recognition of its importance, providing new tools for a competitive and integrated innovation process.

Based on an exploratory study focused on the research of academic sources, organization of contents, professionals' interviews and some case studies, this research points out to a new vision, where the package is able to work for the brand if handled with an strategic design mindset, supported by a projectual approach associated with both marketing objectives and brand planning, which amplifies the designer and marketing executives' responsibilities.

After all, design is not restricted to aesthetical activities but involves a function that relates to information management, which begins and ends in marketing and that expresses itself through visual communication. 


\section{Sumário}

Resumo

Abstract

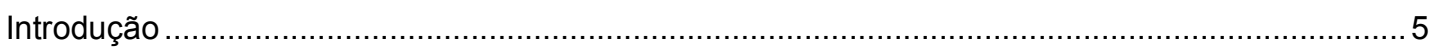

Capítulo 1 A evolução do papel da Embalagem e as abordagens de Marketing ........................... 11

1.1 - As embalagens quando o auto-serviço ainda não existia: 1900 a 1950 ............................11

1.2 - O casamento perfeito entre as embalagens e o auto-serviço: 1950 a 1970 .......................22

1.3 - A multiplicação das embalagens nas gôndolas e as marcas próprias: 1970 a 1990 ...........31

1.4 - O valor estratégico da embalagem na construção do Brand Equity: 1990 aos dias atuais. 36

Capitulo 2 Embalagem, marca e integração .......................................................................... 44

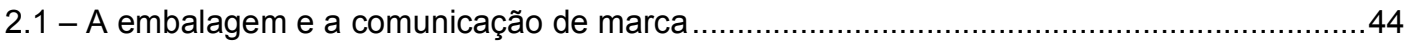

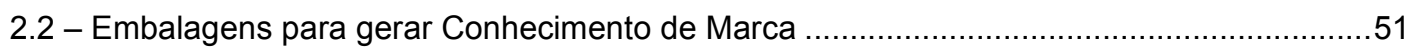

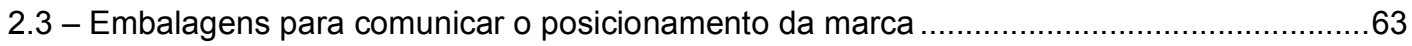

2.4 - Embalagens para reforçar a percepção de qualidade da marca ............................................73

2.5 - Embalagens para reforçar a personalidade da marca ........................................................

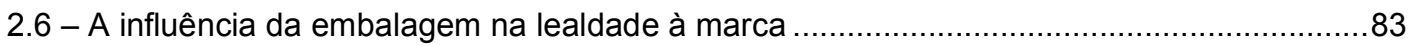

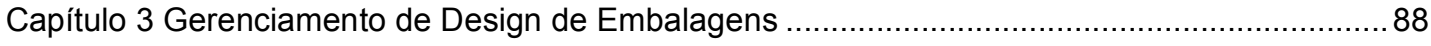

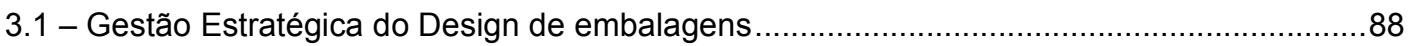

3.2 - Processos, instrumentos e responsabilidades na gestão estratégica de design de

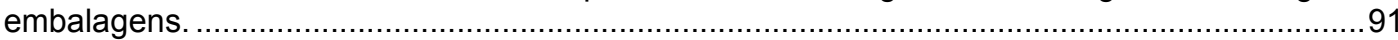

3.3 - Definição do Problema - Brief para design de embalagens ..............................................96

3.3.1 - Elementos do brief de design de embalagens....................................................... 101

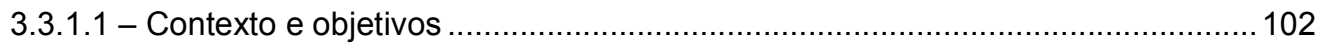

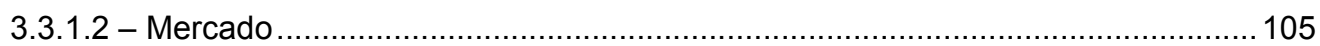

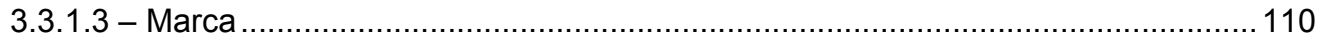

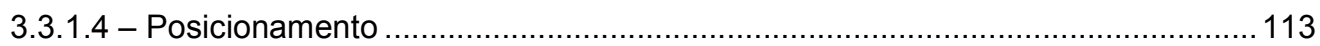

3.3.1.5 - Venda e pós-venda ............................................................................ 117

3.3.1.6 - Desafios para o design de embalagens …...................................................... 118

3.3.1.7 - Limitações técnicas e informações legais ......................................................... 119

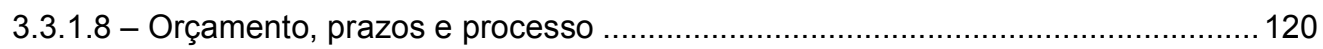

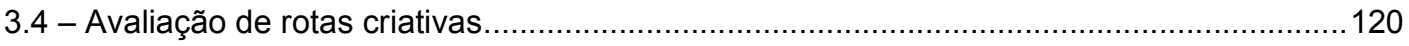

Capítulo 4 Realidades na Gestão estratégica do design de embalagens .................................. 133

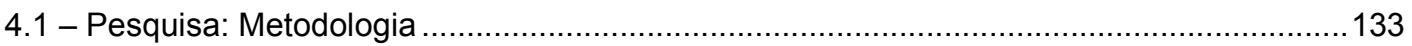

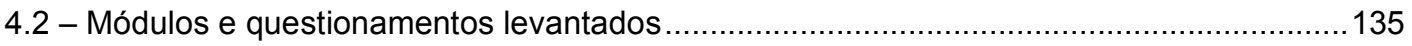

4.3 - Resultado da entrevistas realizadas junto à profissionais envolvidos no design de

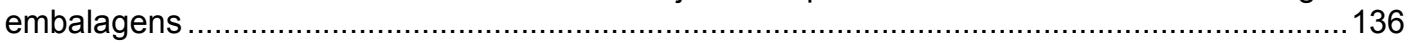

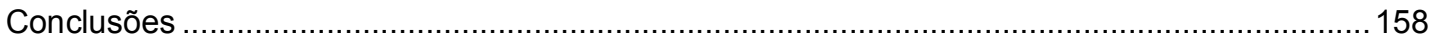

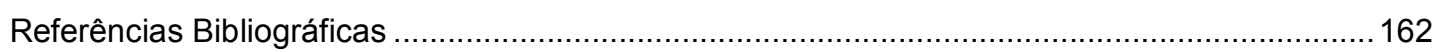

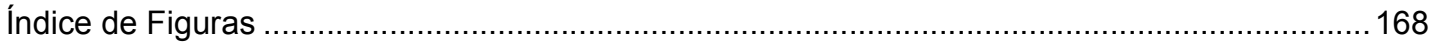

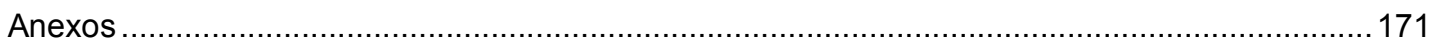




\section{Introdução}

Desde que a embalagem começou a desempenhar uma função comercial no começo do século $\mathrm{XX}$, o papel mediático é parte integrante de suas atribuições, em maior o em menor grau. Afinal, com ou sem o apoio da publicidade, a embalagem sempre foi, em algum momento, o veículo de comunicação inevitável de um fabricante, de um produto ou de uma marca para um consumidor; a embalagem sempre esteve a serviço da marca.

A marca foi gradativamente valorizada nas embalagens a longo dos tempos, que aos poucos foi migrando de um instrumento de identificação do fabricante ou do produto para uma espécie de ferramenta simbólica da marca.

Suas funções junto à marca foram evoluindo, hora funcionando como uma interface comunicativa e funcional junto ao consumidor, hora viabilizando novas estratégias de marketing.

As potencialidades comunicativas da embalagem vêm despertando cada vez mais a atenção em um momento onde se diferenciar e transmitir uma imagem positiva nunca foi tão necessário para as marcas: os consumidores contemporâneos estão cada vez mais exigentes, bem informados, mais interativos e cientes de seus direitos e poderes; querem mais pelo seu valioso tempo e dinheiro, não se contentando mais com promessas infundadas.

Conscientes de seu poder dentro da dinâmica mercadológica e fortalecidos ao longo de anos de propaganda, de lançamentos de novos produtos e de promessas diversificadas, os consumidores, ao chegarem às gôndolas e ao depararem-se com uma quantidade cada vez maior de opções indiferenciadas, passaram a adotar uma postura incrédula e insensível às tradicionais práticas do Marketing, optando, freqüentemente, pelo menor preço, para desespero, principalmente, das 
grandes marcas.

Se, por um lado, os consumidores têm ganhado poder, os fabricantes, por outro, vêm se fragilizando diante de um cenário econômico em profunda e constante transformação, marcado pelo aumento da competitividade, pela comoditização ${ }^{1}$ dos produtos, pelo amadurecimento dos mercados, pela proliferação de opções, pelo aumento do custo das inovações, pela centralização do poder no varejo e pela erosão da mídia tradicional, entre outros fatores.

Se no século passado bastava que a publicidade enaltecesse as virtudes do produto ou de seu usuário, hoje os olhares se voltam para o ponto de venda, onde compreender como se escolhe uma marca quando todas são possíveis, entender como funciona a embalagem, no momento da compra, quando todas se misturam, pode fazer diferença para as companhias (CHETOCHINE, 1999, p.16).

Todas essas mudanças têm resultado em grandes desafios às organizações contemporâneas e vêm afetando profundamente o consumo bem como o modo com o qual os consumidores interagem com marcas e produtos.

Nesse contexto, ganharia a embalagem maior destaque e até mesmo protagonismo como ferramenta de comunicação da marca já que, estando o consumidor mais receptivo a novos produtos, a decisão cada vez mais se efetivará no ponto de venda?

\footnotetext{
11 Segundo Martins e Blecher (1997), quase todas as marcas se nivelaram em qualidade (afinal a tecnologia, hoje, está ao alcance de todos), preço e benefícios, passando a ser tratadas pelos consumidores como "commodities" - nesse contexto, interpretadas como um produto sem diferencial, encontrado em grandes quantidades e em qualquer lugar, cuja decisão de compra está mais vinculada ao preço do que às qualidades do produto ou à imagem da marca. Ainda segundo os autores, a disseminação da percepção de commodities pelos consumidores é fatal para as empresas que construíram marcas ineficientes, pois os compradores tendem a decidir-se, cada vez mais, por produtos genéricos se não forem convencidos que um preço superior oferece benefícios relevantes no curto prazo.
} 
Essa discussão, por mais atual que possa parecer, data do início da década de 50 e 60, onde começava a se estabelecer o sistema de auto-serviço, onde se iniciava o uso massivo da propaganda e onde o design de embalagens dava seus passos iniciais como ferramenta estratégica da marca.

A idéia de que através do design de embalagens seria possível adicionar valor tanto para a marca quanto para o consumidor também não é nova, e, muito antes que se desenvolvesse o conceito de imagem de marca, já se pensava na embalagem como mais que um invólucro protetor do produto, como uma "verdadeira personalidade que entra no lar do cliente, [...] participando de sua vida e até mesmo gerando percepções e sentimentos" (PILDITCH, 1961, p.9, tradução nossa).

De lá pra cá, entretanto, por mais que se tenha consciência sobre o poder comunicativo e a capacidade persuasiva das embalagens, poucos são os profissionais que reconhecem seu caráter estratégico e que instrumentam essa consciência de forma objetiva e estruturada a serviço da marca.

Dada a sua complexidade, onde se fundem diversas áreas do conhecimento como a engenharia, o design, o marketing e a comunicação, por vezes, as preocupações maiores acabam centradas nas questões funcionais, ergonômicas, produtivas e logísticas, relegando-se as potencialidades mediáticas a um segundo plano, aonde o discurso gira simplesmente em torno da necessidade de visibilidade no ponto de venda, sem necessariamente considerar os objetivos estratégicos de negócio, a necessidade de estabelecer um posicionamento competitivo ou de construir imagem forte a partir de uma mensagem estética integrada ao discurso da marca.

Apesar de reconhecida importância, o design de embalagens ainda constitui uma atividade amadora visto que, com raras exceções, é desenvolvida como algo aparte do planejamento da marca e de 
marketing, como uma atividade centrada na capacidade artística do designer e submetida ao senso estético do profissional de marketing, quando deveria ser suportada por uma abordagem projetual, integrada à estratégia da marca, e por um trabalho de equipe, uma vez que o design de embalagens não se restringe à manipulação de recursos visuais ou a uma função exclusiva do designer: o design de embalagens é uma função que começa e termina no marketing e que se expressa por meio da comunicação visual.

Talvez, ao mesmo tempo em que o nascimento do auto-serviço vislumbrou uma série de possibilidades e oportunidades para o design de embalagens, as crises econômicas aliadas ao desenvolvimento dos meios de comunicação de massa, como o rádio e a TV e o foco dado à propaganda, acabaram contribuindo para que sua evolução se desse em passos mais lentos, que agora começam a ser recuperados.

Afinal, hoje, não é mais suficiente que a embalagem seja bonita e impactante: é preciso que a embalagem seja encarada como uma peça de comunicação visual a serviço da marca, inserida em uma mentalidade de gestão estratégica.

Como elemento de identidade e de comunicação de marca, o design de embalagens deve desenvolver, na economia das marcas fortes, o papel fundamental de fortalecê-las a partir da criação de associações relevantes, da contribuição para uma experiência positiva com a marca e da tradução do seu posicionamento, de seus valores e de sua essência em vantagem competitiva para a companhia. Só assim a embalagem estará cumprindo seu papel estratégico.

É imprescindível, para tanto, uma maior clareza de propósito em sua pesquisa, planejamento, desenvolvimento e avaliação, por parte de todos os profissionais envolvidos nesse processo, sejam esses designers, comunicadores ou executivos de marketing, com o objetivo de criar significado e ressonância para a marca. 
Dada a complexidade de tipos e a vastidão de funções a que se destinam, cabe realizar um recorte nesse universo de possibilidades a fim de dar um maior foco ao objeto de estudo.

Trataremos aqui somente das embalagens primárias, cujo continente é indissociável da idéia do conteúdo, embalagens do mercado de bens de consumo imediato, cujo principal meio de distribuição e comercialização seja o sistema auto-serviço alimentar, embalagens que consistam um uma unidade de contato no ponto de venda possuindo, portanto, um sistema visual (estrutural e gráfico) de caráter mediático expressivo, e que pertençam, principalmente às categorias de higiene-beleza e limpeza, em função do conhecimento ${ }^{2}$ da autora desses segmentos, mas também a alimentar, para efeito de uma maior base de exemplificação.

Adicionalmente, não dissociaremos o rótulo da estrutura tridimensional: consideraremos a embalagem como sistema único e coeso de informação e comunicação visual, aonde suas partes integrantes, sejam estas os rótulos (ou elementos gráficos) ou sua estrutura formal se unem para significar em prol da marca.

Tendo como base o recorte acima citado, faremos nesse primeiro capítulo uma abordagem diacrônica da evolução da embalagem ao longo do último século, buscando esboçar o cenário no qual se inseria tanto no Brasil quanto no mundo, como se relacionava com as abordagens de marketing e da publicidade bem como suas principais contribuições e avanços na comunicação de marca.

Tendo conhecido um pouco do seu desenvolvimento em função dos principais acontecimentos mercadológicos e sócio-culturais do século XX, através do segundo capítulo será possível compreender, de modo mais aprofundado, as atribuições e potencialidades da

\footnotetext{
2 Em função de experiência profissional atuando nessas categorias de produtos, tanto na área de desenvolvimento de embalagens quanto em gestão de marcas.
} 
embalagem bem como os impactos na comunicação e na formação de imagem da marca. Serão apresentados inúmeros exemplos de embalagens recolhidas do mercado, analisadas em função da capacidade de gerar conhecimento para a marca, de estabelecer um posicionamento competitivo, de aumentar a percepção de qualidade e de contribuir para o aumento da lealdade, e como isso se reflete em valor para a companhia e para o consumidor.

Mas, as embalagens só serão capazes de desempenhar esse papel se seu caráter comunicativo for devidamente manipulado. Se forem geridas a partir de uma mentalidade estratégica de design, tema a ser tratado no capítulo III.

Por fim, no quarto capítulo serão apresentadas as opiniões de profissionais e especialistas a respeito do tema de modo a confrontar as recomendações teóricas às praticas de mercado, bem como avaliar o cenário atual do design de embalagens no Brasil. 


\section{Capítulo 1}

A evolução do papel da Embalagem e as abordagens de Marketing

Como as embalagens têm evoluído em função do desenvolvimento da industrialização e da comercialização de produtos? Quais eram suas principais funções e que novas responsabilidades incorporaram ao longo do tempo? Como se relacionavam e como se relacionam com as atuais estratégias de marketing? Essas são algumas questões a serem exploradas na abordagem diacrônica a seguir.

\section{1 - As embalagens quando o auto-serviço ainda não existia: 1900} a 1950

Se avaliarmos a embalagem desde o ponto de vista da proteção ou da portabilidade de um determinado objeto ou produto, é possível remeter seu surgimento à era primitiva, onde, há milhares de anos atrás, os homens já utilizavam "sacolas" ou "bolsas" feitas de folhas ou peles animais, especialmente desenvolvidas para proteger e transportar alimentos, bebidas ou quaisquer outros bens considerados valiosos pelos membros dessas antigas comunidades.

O fato é que as embalagens, ou ao menos suas formas predecessoras, têm sido testemunhas e mesmo influenciadoras da evolução do estilo de vida das pessoas, da era pré-histórica aos dias atuais.

"A embalagem define culturas e períodos de tempo, e é fascinante ver como uma marca pode evoluir através da embalagem para se manter relevante". (GOBÉ, 2002, p.262).

De qualquer forma, foi com a origem do auto-serviço que a embalagem ganhou destaque dando seu maior salto em termos de ferramenta de marketing e de importância mercadológica (MESTRINER, 
2005)

Do começo do século XX até 1950, quando surgiram os primeiros supermercados no país, predominavam no Brasil os armazéns de secos e molhados, onde eram vendidos itens básicos de consumo, a maioria a granel, sendo que alguns poucos como doces, biscoitos, bebidas, sabão, remédios, fiambre, charutos e cigarros já vinham embalados de fábrica.

Esses poucos itens, no começo do século, representavam quase a metade do total de produtos empacotados e com marca, disponíveis no Brasil. (CAVALCANTI, 2006, p.31).

Os donos desses estabelecimentos se orgulhavam em atender às necessidades de sua vizinhança local, estabelecendo um vínculo muito próximo e pessoal com cada cliente, o que contribuía para a constituição de uma clientela permanente, baseada em uma relação de confiança mútua. Ao mesmo tempo, o consumidor não tinha acesso livre aos produtos, dependendo da ajuda do comerciante para ver, tocar e pesar o produto. Além disso, as lojas ou empórios eram dedicadas a públicos específicos, exacerbando as diferenças sociais (CHETOCHINE, 1999).

As mercadorias vendidas eram freqüentemente embaladas pelos donos das lojas e, por isso, suas bancadas eram repletas de barricas com produtos vendidos a granel, ocupando cada centímetro da venda.

Gradualmente, alguns fabricantes e comerciantes começaram a perceber que as embalagens não só protegiam os produtos da deterioração e de danos como também serviam para chamar a atenção dos clientes e facilitavam a recompra - as pessoas que levavam o produto e que gostavam, voltavam a comprá-lo por lembrar da aparência física da mercadoria e da marca estampada na embalagem. O mercado lentamente começava a apreciar o poder da embalagem, 
entendendo que oferecer mercadorias pré-embaladas era um meio mais eficiente de comercialização, manuseio e estocagem de produtos. (MEYERS; GERSTMAN, 2005, p.23).

Começa a função de identificação da embalagem. A embalagem deveria ser o estandarte da marca possibilitando seu reconhecimento. Deveria permitir que qualquer pessoa pudesse identificar a marca ou fabricante do produto, de que produto se tratava e qual seu conteúdo e, assim, efetuar a recompra, caso o produto atendesse às suas necessidades.

No mundo, entre as marcas pioneiras deste processo, que reconheceram a efetividade da embalagem e aproveitaram a vantagem desse novo método de vendas, estavam Quaker, Hershey's, Coca-Cola e Ivory Soap. ${ }^{3}$

No Brasil, o cigarro foi um dos primeiros produtos a tirar proveito do aspecto visual da embalagem para atrair o consumidor. Algumas embalagens exibiam a imagem do dono, da fábrica ou das premiações recebidas em feiras industriais, ícones que atestavam a qualidade do produto. (CAVALCANTI, 2006, p.33). Interessante notar que até hoje esses são símbolos utilizados para denotar credibilidade, competência e tradição de alguns produtos, como, por exemplo, bebidas - não é raro encontrar embalagens de algumas marcas que tenham medalhas e brasões compondo seu design gráfico.

A produção industrial, até então, era muito rudimentar. Somente a partir da Primeira Guerra Mundial (1914-1918) é que a indústria, em geral, começou a se desenvolver.

No Brasil, a drástica diminuição do transporte marítimo por ocasião da guerra, fez os industriais brasileiros verem-se livres da concorrência inglesa, possibilitando o desenvolvimento da indústria

\footnotetext{
${ }^{3}$ Ivory Soap é uma marca de sabonetes da Procter \& Gamble.
} 
nacional.

Os imigrantes, aqui chegando, incorporaram-se rapidamente ao comércio e à indústria emergente, contribuindo para o desenvolvimento das cidades e da diversificação de serviços e produtos comercializados.

Surgiam as primeiras fábricas de vidro para abastecer as cervejarias, as de lata para produtos alimentícios e as de papel de embrulho.

A Guerra também proporcionou uma aceleração da tendência ao uso de embalagens individuais e de embalagens menores devido à necessidade de distribuição de quantidades unitárias de alimento às tropas, bem como da redução do número de pessoas por família. Além disso, possibilitou o desenvolvimento de novas técnicas de lacramento, já que os alimentos necessitavam ter uma maior durabilidade, culminando no desenvolvimento de melhores técnicas de produção e impressão de embalagens como um todo. Assim, as funções de proteção, de conservação e de transporte das embalagens foram aprimorados, bem como a idéia de que a embalagem poderia ser adaptada às necessidade de uso e do usuário.

Os EUA despontaram da Guerra como a nação mais poderosa do mundo e a indústria norte-americana tornou-se responsável por mais de $50 \%$ da produção industrial mundial.

Começaram a se instalar no Brasil algumas empresas multinacionais, principalmente americanas e européias, auxiliando na diversificação da produção de gêneros no país, que se resumia a banha, massas e bebidas.

Até a década de 20 , mais da metade da renda dos trabalhadores era destinada à alimentação. O mercado de higiene praticamente não existia, restringindo-se a alguns poucos produtos importados da França e ao uso de sabão de banha e sabão de coco, estes últimos sim acessíveis à maior parte da população. 
A atividade publicitária só começou de fato a se desenvolver no Brasil a partir da década de 30 . Até este momento era vista como uma atividade marginal e poucas eram as empresas que aceitavam fazer anúncios para seus produtos, uma vez que a crença era de que se um produto fosse bom ele se venderia por si só, dispensando qualquer tipo de "ação propagandista" (GESSY LEVER..., 2001).

A Gessy Industrial, sucessora da brasileira José Milani e Cia, foi a primeira empresa a lançar no Brasil um sabonete de toucador, como era chamado na época, inaugurando o mercado de Higiene e Beleza com a marca Gessy em 1913, que viria a consolidar-se somente a partir do final dos anos 20 .

Analisando mesmo que superficialmente os elementos formais que constituem a embalagem do sabonete Gessy, é interessante notar a riqueza de mensagens que a embalagem transmite, especialmente a idéia de posicionamento de produto através da embalagem, quando esse conceito ainda estava longe de existir. Quanto aos elementos, pode-se dizer que:

- A marca Gessy está evidenciada na porção central da embalagem, bem como a descrição do tipo de produto: que a embalagem contém - sabonete;

- O benefício racional se exprime verbalmente "Conserva, amacia aromatiza e embeleza a cútis";

- Os elementos visuais estão conectados ao texto, ressaltando a função cosmética do produto. A moça em pose inspiradora, detentora de uma pele branca e delicada, com um vestido fresco, e tendo ao fundo uma penteadeira, imagem emoldurada por rosas, reforça os atributos de cuidado, perfumação e frescor, e o benefício de beleza e encanto;

- A situação de uso também é informada: "insubstituível no 
banho de adultos, crianças e recém-nascidos", o que reforça as credenciais de suavidade, visto que o uso em bebês é prova absoluta da delicadeza de um produto para com a pele.

As embalagens começavam a exercer uma função mediática na comunicação do produto com o público, que só tendia a se sofisticar com o passar do tempo.

Desse modo, mesmo que timidamente, as embalagens buscavam comunicar os benefícios do produto, bem como suas propriedades cosméticas e medicinais em um momento em que a mulher começava a se preparar para receber as novidades do mundo da beleza. Afinal, diferentemente da mulher do século XIX, a "moderna" mulher dos anos 20 já não estava mais condenada à reclusão doméstica, podendo agora ser vista em eventos sociais, jornais e revistas, mudança de hábito que certamente amparou o nascimento de uma cultura de cuidado pessoal e beleza, dando condições ao pleno desenvolvimento do segmento (GESSY LEVER..., 2001, p.79).

Em termos gráficos, o design das embalagens ainda refletia as preferências artísticas do século XIX. Somente a partir dos anos 20, se renderia à influencia do art nouveau para atrair os consumidores através

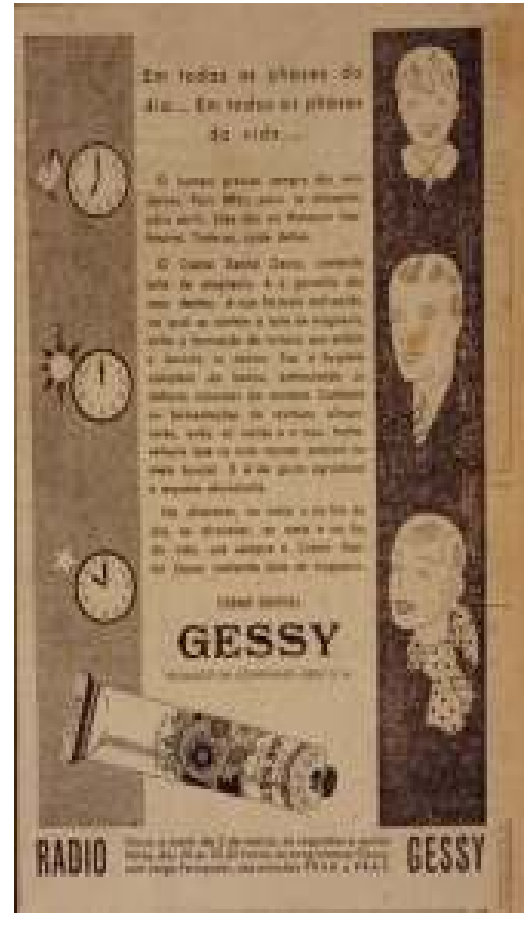

Figura 2: Anúncio "educativo" do creme dental Gessy-1933. de uma aparência "moderna". Os principais materiais empregados na fabricação dessas embalagens eram o vidro, o papel e o aço.

A propaganda, sempre educativa e impressa até então, exercia praticamente uma função social, chamando a atenção dos consumidores para a necessidade e importância do uso dos produtos, justificados pela criação de hábitos mais saudáveis de vida.

No anúncio de creme dental Gessy de 1933, é interessante observar que ao mesmo tempo em que aborda os atributos do produto, coloca a importância do uso do creme dental na manutenção de dentes saudáveis, educando o consumidor a utilizá-lo várias vezes ao dia - 
pela manhã, após o almoço e após o jantar.

Esse tipo de anúncio, em que se ressaltava a promessa do produto e a razão pela qual deveria ser utilizado, somado a um tom educativo de comunicação, caracterizava bem a propaganda até os anos 30 , quando a novidade do rádio viria a alterar significativamente esse panorama.

Nesses anúncios do sabonete Gessy de 1934 e 1935, respectivamente, a linha de comunicação estava voltada para a importância de manter a aparência jovem através de uma pele bonita e bem cuidada. A resposta para essa necessidade seria o uso do sabonete Gessy, único capaz de limpar delicadamente os poros, trazendo frescor e jovialidade para a cútis, e assinava - "Puro como a rosa que Ihe dá a cor".

A mulher dos anos 30 era moderna e a beleza estava entre suas principais preocupações; a embalagem, alinhada à comunicação dos anúncios, refletia a mensagem do produto por meio de um design muito mais limpo, simples e estilizado. Inspirado no movimento art decó, com cores puras, linhas angulares, composição equilibrada e simples, remetia à modernidade, sem deixar de transmitir os atributos de feminilidade, pureza, delicadeza e maciez.

Tanto o design das embalagens quanto os anúncios publicitários, aparentemente alinhavam-se à comunicação de uma mesma mensagem ao consumidor, denotando uma preocupação, mesmo que intuitiva, em manter a mensagem emanada pelas diferentes mídias, potencializando a comunicação e tornando-as mais memoráveis, fossem elas mídia impressa ou a própria embalagem.

A tecnologia de embalagem continuava se
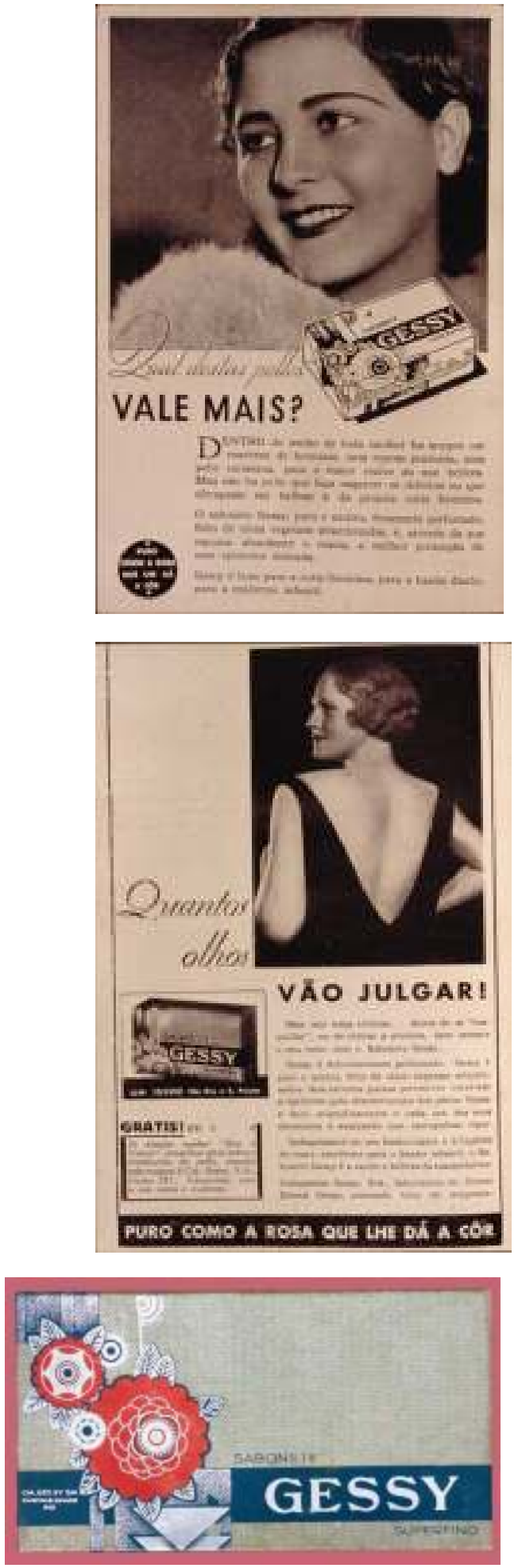

Figura 3: Anúncios do sabonete Gessy de 1934 e 1935, respectivamente, e da embalagem sabonete Gessy, de 1925 ao início dos anos 40 
aperfeiçoando: surgiam o celofane e os enlatados como substitutos mais leves aos vidros.

Com a vinda das multinacionais de higiene e beleza como a Irmãos Lever, a Colgate e a Johnson \& Johnson, bem como das multinacionais automobilísticas, as primeiras agências de propaganda internacionais começam a se instalar no país a fim de promover os produtos das indústrias norte-americanas.

Além disso, essas indústrias chegaram ao Brasil trazendo as últimas novidades em técnicas de marketing e propaganda, até então desconhecidas por aqui, mas que não tardariam em ser adotadas pelas empresas nacionais. Foram também essas indústrias que começaram a desenvolver critérios de qualidade e o interesse pela opinião do público, elevando os produtos disponíveis a uma categoria superior.

Assim, em 1932, foi lançado o sabonete Lever (Lux a partir da década de 50), inaugurando uma nova maneira de falar com o público a partir do endosso das mais belas e bem sucedidas atrizes do cinema. Após 1935, Lux passaria a assinar: "Nove entre cada 10 estrelas do cinema usam Lever. Lever, o sabonete das estrelas". (GESSY LEVER..., 2001, p.21), o que contribuiu para a construção de um universo simbólico de marca, ligado ao mundo das belas atrizes "hollywoodianas", que tinham todos aos seus pés.

Na mesma época, surge nos Estados Unidos o auto-serviço que, apesar de inicialmente constituir uma alternativa de redução de custos face às conseqüências da crise de 1929, converter-se-ia nos anos seguintes em uma maneira mais prática e rentável de comprar e vender (CAVALCANTI, 2006, p.133).

Aos poucos, tanto a França quanto a Inglaterra deixavam de ser a referência cultural e econômica para o Brasil, o American Way of Life difundia-se e com a iminência da Segunda Guerra Mundial, os EUA começariam a estreitar as relações com o Brasil.
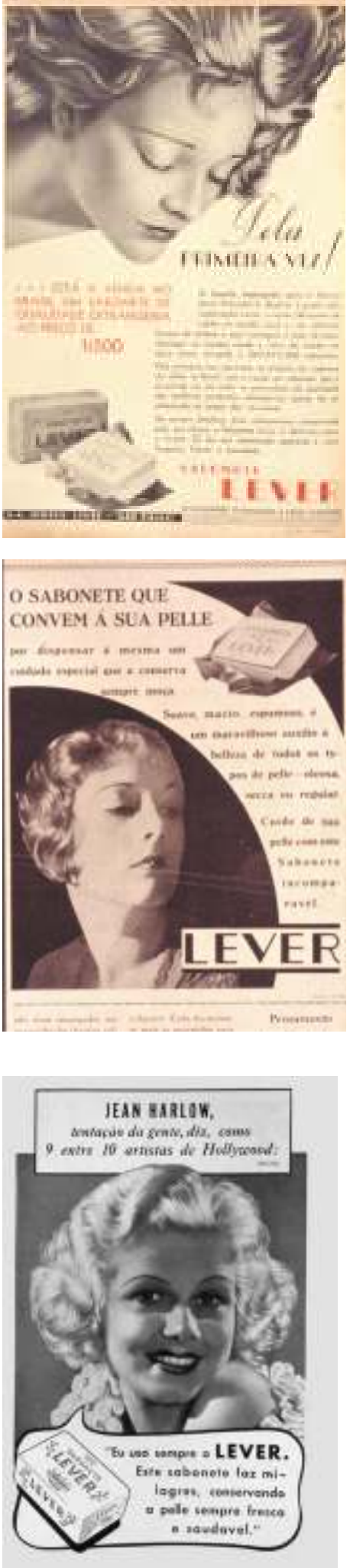

Figura 4: Primeiros anúncios do sabonete Lever. 1932, 1934 e 1935, respectivamente. 
O design de embalagens era até este período desenvolvido dentro das agências de publicidade, não constituindo, entretanto, uma atividade de prestígio entre os publicitários, já que não concorria com as novidades do século XX, como o rádio (cujos anos "dourados" foram os 30 e os 40 ) e a televisão (dos anos 50 ). Somente no fim da década de 40 é que essa função começou a ganhar destaque no Brasil, principalmente, impulsionada pelo aprendizado que tanto os empresários dos Estados Unidos quanto os da Europa tiveram com a operação dos supermercados, que já se encontravam em uma fase mais madura nessas regiões.

Apesar da primeira transmissão de rádio ter acontecido em 1922, somente a partir de 1930 é que as companhias foram autorizadas a veicular anúncios. A Irmãos Lever foi uma das empresas que, já na década de 40, começou a explorar o enorme potencial desse meio. Por vários anos tanto a Lever quanto a Gessy patrocinaram vários programas de auditório e rádio-novelas, chegando até mesmo a produzir algumas delas.

No final dos anos 30, a Guerra mais uma vez se refletiu no design e na tecnologia de embalagens, que passaram a ser adaptadas para vários países devido à escassez de matérias-primas e tintas para impressão. Os rótulos foram reduzidos e simplificados a fim de economizar papel e tinta, tornando o conceito de embalagem mais funcional e fazendo com que a comunicação na embalagem retrocedesse para somente a identificação de marca.

Os recursos naturais limitados e a escassez do pós-guerra perduraram e os países não afetados continuaram a exportar principalmente alimentos enlatados ou em pó para a Europa, o que contribuiu enormemente para o desenvolvimento de embalagens mais eficientes, principalmente na conservação de produtos pereciveis.

A economia e os recursos naturais restritos na Europa fizeram 
com que o design de embalagens adotasse um estilo mais prático e simples na década de 40 (TAMBINI, 1996, p.241). Apesar do impacto da guerra no Brasil ter sido menor, de alguma forma influenciou também no design de embalagens, que passaram a adotar grafismos mais contidos e "econômicos", como no design do sabonete Gessy desenvolvido no início dos anos 40 pela filial brasileira do escritório do designer americano Raymond Loewe. ${ }^{4}$

Os anúncios de 1945, 1948 e 1949, respectivamente, evidenciam o momento de Guerra e do pós-guerra não só pela aplicação de cor nos anúncios, mas pela clara mudança de imagem da mulher, muito mais independente e expressiva, condição que ganhou ao assumir a liderança da família nos tempos de guerra. Apesar da mensagem da marca continuar embasada no cuidado da pele para uma jovialidade prolongada, o público alvo refletido no anúncio modificou-se por completo: uma mulher com muito mais atitude, feliz, bonita "por fora e por dentro".

Nesse contexto, a embalagem do início dos anos 40 alinhava-se claramente com a linguagem do anúncio de 1945, transmitindo uma mensagem consistente - a flor perde relevância, influenciando na percepção de delicadeza, maciez, feminilidade e pureza, mas não deixa de existir, remetendo ao produto anterior que as pessoas conheciam; os elementos gráficos duros e retos, aliado às cores cinzentas, remetiam os difíceis e realistas anos de guerra, onde o romantismo feminino perdera espaço, ao mesmo tempo em que o produto ganhava um atributo diferenciador - vitamina F. Um design muito mais funcional para tempos em que o desempenho funcional era mais importante que as necessidades emocionais dos

\footnotetext{
${ }^{4}$ Raymond Lowe foi um dos grandes nomes do Desenho Industrial entre as décadas de 40 e 50. Entre seus grandes trabalhos encontra-se a criação da embalagem da CocaCola.
}
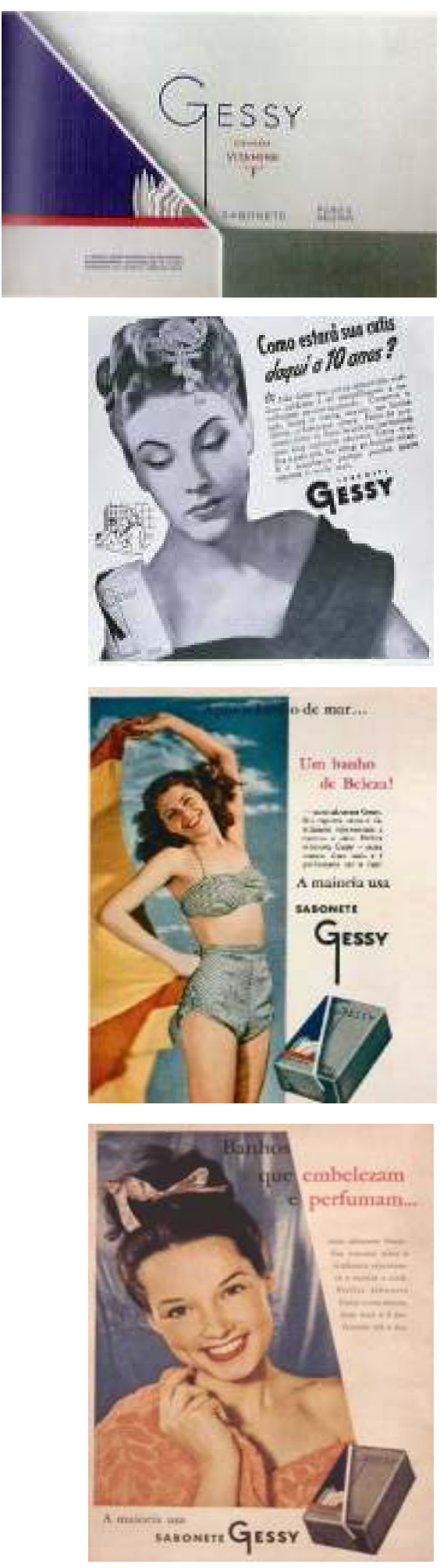

Figura 7: Embalagem do sabonete Gessy de 1940 e anúncios do final da década de 40. 
consumidores.

Esse alinhamento entre a mensagem transmitida pela embalagem e pelos anúncios já não se evidenciava nos cartazes de 1948 e 1949, que demonstravam a postura da "mulher que usa Gessy" a partir dos anos 50 a linha de produtos ganharia um novo design, mais alinhado à comunicação da marca e à consumidora que se atualizavam.

A volta dos soldados para casa após a Segunda Guerra Mundial, a necessidade de acomodar as famílias, os altos custos, a explosão da taxa de natalidade e a nova configuração do lar onde não só o homem trabalhava, mas a mulher também, deram origem ao lançamento de uma variedade de produtos do tipo "faça fácil". A necessidade de refeições prontas ou pré-prontas entre outras soluções variadas que tornavam mais simples a vida das pessoas, deram origem a um número jamais visto de opções enlatadas, engarrafadas e encaixotadas. As embalagens possibilitaram uma vida mais prática para todos (MEYERS; GERSTMAN, 2005, p.33).

Com a movimentação econômica do pós-guerra e a mudança dos hábitos da sociedade, as embalagens rapidamente se tornaram a preocupação central de muitos fabricantes, retomando a evolução freada durante os tempos de guerra. Muitos produtos e novas categorias que começaram a surgir necessitavam de formas mais atrativas de embalagem, novos conceitos visuais e características que pudessem atingir diferentes tipos de consumidores, endereçando necessidades distintas, afinal, não era mais somente a mãe de família a responsável pelas decisões de compra, as embalagens precisavam falar com públicos distintos como adultos, jovens e crianças.

Ao mesmo tempo em que as embalagens ganhavam importância, os comerciantes perceberam que as mercadorias expostas e mais próximas dos consumidores eram muito mais compradas que as demais. Começaram, então, a transformar todo o interior das mercearias 
em verdadeiras vitrines, nas quais se podia ver e escolher todas as mercadorias. A partir da década de 50, surgem os novos mercados, inaugurando o conceito do auto-serviço.

No Brasil, em 1941 é inaugurada a CSN e, em 1953, a Petrobrás que contribuíram fortemente para o desenvolvimento da indústria de embalagens no Brasil.

1.2 - O casamento perfeito entre as embalagens e o auto-serviço: 1950 a 1970

Os anos 50 constituem os anos ativos das marcas e de um novo recomeço da embalagem como ferramenta de comunicação do produto.

Com o fim da Segunda Guerra Mundial, houve uma retomada industrial em todo o mundo. O consumidor, como reflexo da guerra, estava carente de todo tipo de produto e solução e, por isso, tornava-se mais facilmente influenciável. A escassez de bens, resultante do período pós-guerra, marcou profundamente as relações de consumo. Os bens eram caros, tinham baixa disponibilidade e pouquíssimas opções de escolha, logo, as pessoas contentavam-se facilmente com o que os fabricantes ofertavam sendo fortemente influenciadas pela conveniência do marketing de massa, caracterizando consumidores conformistas e dependentes (LEWIS; BRIDGES, 2004).

A baixa penetração de bens nos lares aliada a essa escassez generalizada de artigos resultava em uma grande oportunidade para a indústria e para o comércio, que aos poucos retomavam suas atividades. No Brasil, chegaram nos anos 50 os supermercados que, poucos anos depois se consolidariam como a mais bem sucedida forma de varejo no país.

A chegada dos supermercados passou de imediato também a influir 
fortemente nas indústrias, nos atacadistas e nos fornecedores em geral, seja pela imediata necessidade de embalagens apropriadas, seja também pela mudança de rotina do tradicional relacionamento entre o vendedor e o comprador. [...] Todos vislumbravam ali uma inédita novidade no mercado brasileiro, evidenciando em seu bojo grandes oportunidades para a criação de campanhas destinadas a promover a divulgação daqueles novos estabelecimentos como, também, dos milhares de produtos neles expostos (CINQUENTA ANOS DE SUPERMERCADOS NO BRASIL, 2002, p.59).

Os consumidores, aos poucos, familiarizavam-se com o novo conceito de compra e venda, afinal, o supermercado era um modo muito mais cômodo e econômico de fazer compras. Grande variedade de produtos centralizados em um só lugar, com preços muito mais atrativos, onde não havia necessidade de aguardar pelo atendimento de um vendedor e onde era possível simplesmente pegar a quantidade desejada de

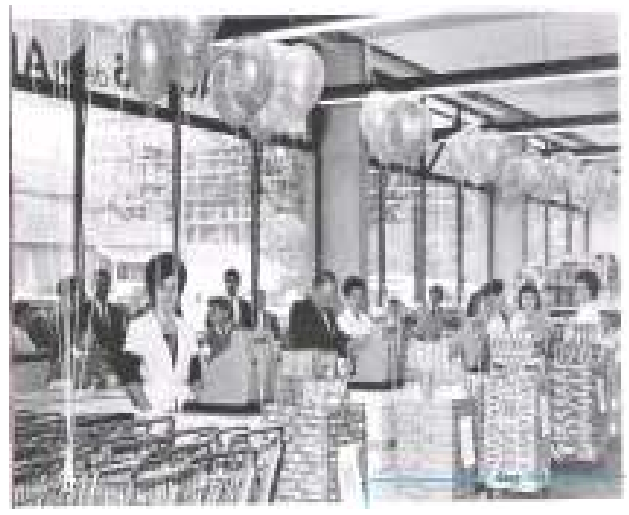
determinado produto, colocar em um carrinho e pagar em um caixa. A embalagem estabelece a sua função de "vendedor

Figura 9: Os supermercados chegam ao Brasil. silencioso" (PILDITCH, 1961), passando a ser a grande defensora e divulgadora do produto no ponto de venda, o que demandava uma evolução em forma e em conteúdo para atender essa nova demanda comunicativa.

Conforme as pequenas lojas foram se expandindo para cadeias varejistas, a embalagem tornava-se um componente essencial na situação de compra. Afinal, não demorou muito para que as companhias percebessem a oportunidade de promover seus produtos, colocando-os em coloridas embalagens que proporcionariam uma plataforma de reconhecimento da marca, promoveriam as qualidades das mercadorias e chamariam a atenção do consumidor no ponto de venda.

Além disso, com o desenvolvimento do varejo, do controle da distribuição, do embarque, do transporte, da estocagem, com a demonstração e a venda de um número cada vez maior de produtos de 
todos os tipos, as embalagens tornaram-se um meio indispensável sem o qual não seria possível operar eficientemente.

O comércio definitivamente modificavase por completo, trazendo uma revolução no mundo das embalagens que, mais do que proteger os produtos, passariam a comunicarse nas gôndolas fazendo 0 papel de "vendedores silenciosos" (PILDITCH, 1961). As companhias foram

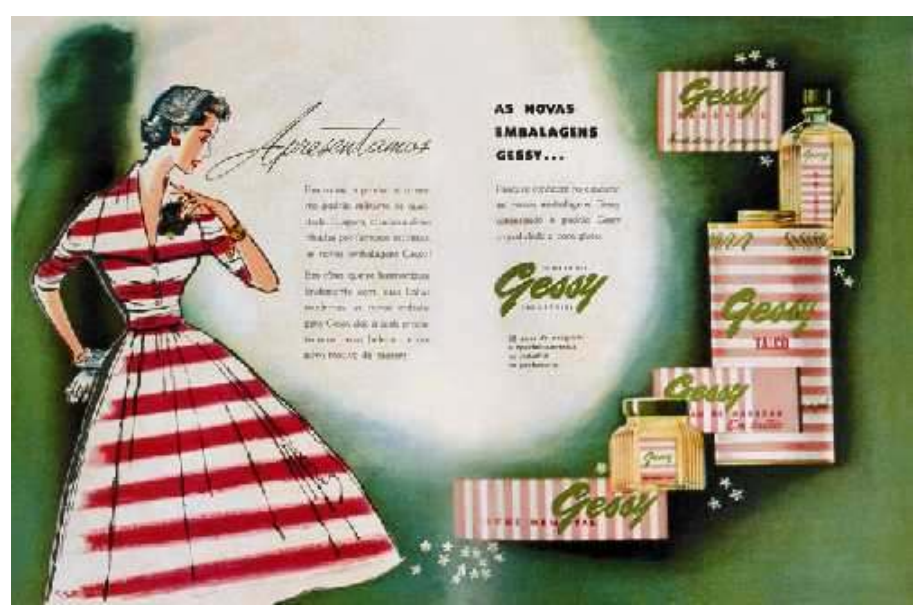
obrigadas a pensar em novas maneiras de apresentar os produtos com textos e imagens que substituíssem os argumentos de vendas do vendedor e, assim, a compra ia deixando de basear-se na confiança em determinado comerciante para depender da influência persuasiva da embalagem

As gôndolas colocaram o consumidor diante de produtos semelhantes, concorrentes, fazendo com que as embalagens ganhassem maior importância no contexto de comunicação da marca, na interação do consumidor com o produto e na viabilização das estratégias de marketing ${ }^{5}$. A embalagem transformava-se em um meio fundamental na comunicação das marcas.

Assim, a indústria de embalagens deu um salto na busca por materiais e soluções que pudessem acondicionar tudo que as pessoas quisessem consumir. $E$ foram os supermercados que passaram a exercer grande influência no modo como essas embalagens eram desenvolvidas, afinal, elas deveriam ser facilmente identificadas no

\footnotetext{
${ }^{5}$ O termo marketing é aqui utilizado no sentido de comercialização e venda, uma vez que somente no início da década de 50 se iniciaram, nos EUA, os "market studies" com o objetivo de melhor compreender o comportamento e a motivação de compra do consumidor do pós-guerra. Apenas na década de 60, o marketing, como o conhecemos hoje, ganha seus contornos iniciais com ao formulação do conceito dos 4 P's por Jerome McCarthy (MITSURO, 2007, p.25)
}

Figura 10: Embalagens da linha de beleza Gessy de 1959. O uso de elementos gráficos memoráveis e únicos, reforçados na comunicação impressa, refletia a preocupação dos fabricantes em dar visibilidade à marca e facilitar seu reconhecimento no ponto de venda. A idéia de uma linha de produtos sob uma mesma marca foi uma estratégia viabilizada pela embalagem, que conferia unidade visual a todos os produtos, reforçando a idéia de "a mesma qualidade do produto que você conhece agora nos outros produtos também". Enquanto Lux era uma marca de sabonetes de beleza, Gessy se posicionava como "linha de produtos de beleza", construindo a idéia de portifólio de produtos sabonete, creme dental, perfume, talco.

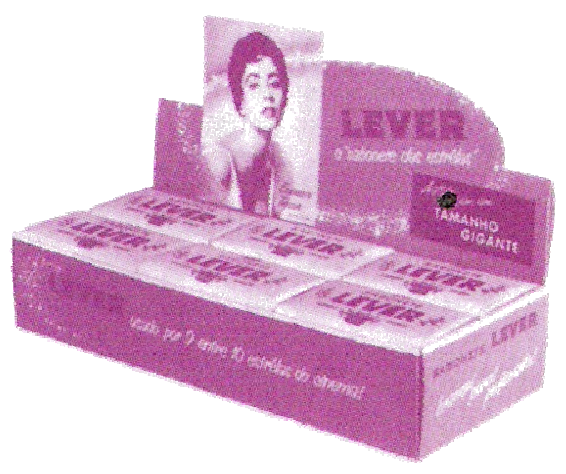

Figura 11: Embalagem display do sabonete Lever da década de 50, ressaltando o testemunhal das estrelas de cinema preocupação em divulgar o produto no ponto de venda. 
ponto de venda, chamar a atenção do consumidor, apresentar uma boa área de exposição, "ficar em pé" nas prateleiras, etc.

Como não eram todos os itens fornecidos que possuíam embalagens, os próprios supermercados muitas vezes providenciavam máquinas de embalar. Os chocolates, por exemplo, eram entregues pelos grandes fabricantes como Lacta e Nestlé em caixas a granel, cabendo ao supermercado o trabalho de dividir em unidades menores e envolvê-las em celofane para consumo familiar ou individual (CAVALCANTI, 2006, p.139).

Paralelamente a essa transformação do varejo, os meios de comunicação em massa explodiam pelo país. Além do surgimento da

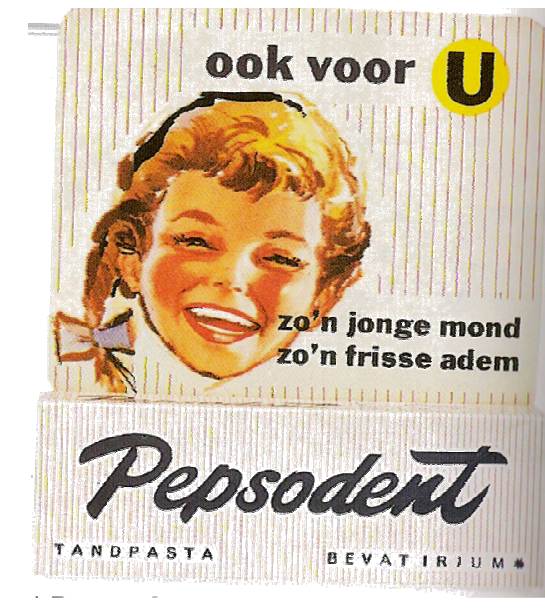

Figura 12: Embalagem de creme dental da década de $60 \mathrm{com}$ "testeira" para ganhar espaço na gôndola e chamar a atenção do consumidor. TV em 1950, jornais e revistas dirigidos para públicos específicos começavam a aparecer por todo o Brasil.

A TV rapidamente passou a constituir um veículo importantíssimo para a evolução da publicidade, sendo amplamente utilizada pelas empresas. Algumas delas chegaram até mesmo a encomendar e a produzir programas e novelas em uma época onde ainda não existiam os intervalos comerciais.

A década de 50 foi definitivamente marcada por inúmeras mudanças em todos os setores. Além das profundas transformações no varejo e nos meios de comunicação que afetaram todo o mundo, foram anos que possibilitaram a real inclusão do Brasil no sistema capitalista e que promoveram um grande crescimento econômico da nação - a criação da CSN, da Petrobrás, a construção de rodovias, ferrovias, hidrelétricas, o estabelecimento da indústria automobilística, a transferência da capital para Brasília, etc, são alguns fatos que ilustram a era desenvolvimentista brasileira, comandada por Juscelino Kubitschek.

Já na década de 60 o sistema auto-serviço começou a firmar-se no mundo e a expandir-se no Brasil. No final desta década, as lojas 
chegariam a comercializar aproximadamente mil e quinhentos itens (CINQUENTA ANOS DE SUPERMERCADOS NO BRASIL, 2002, p.63) e as marcas, ao mesmo tempo em que se democratizavam, também começavam a se dessacralizar. Isso se deu porque os consumidores, com o auto-serviço, passaram a interagir diretamente com produtos e marcas, o que provocou uma profunda mudança no comportamento de compra.

A estratégia publicitária dos anos 60 , embasada nos preceitos da USP - Unique Selling Proposition,

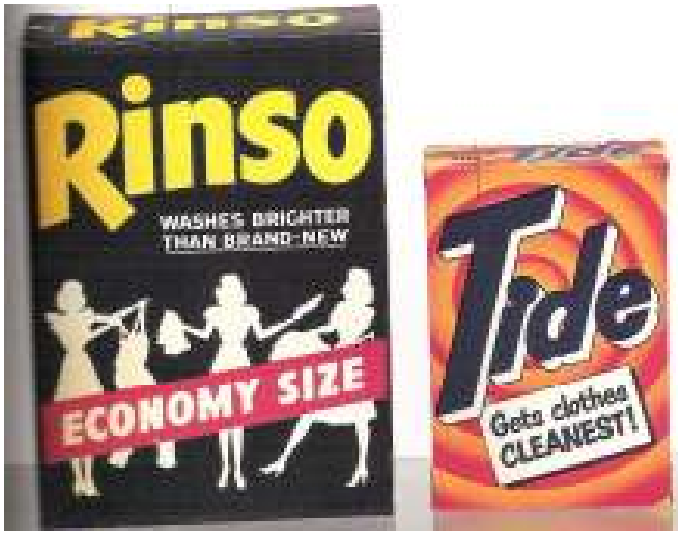

Figura 13: Conceito USP expresso nos sabões Rinso e Tide. Embalagens focadas em comunicar o benefício do produto no fim dos anos 50: Rinso - deixa mais branco do que se fosse novo, tamanho econômico; Tide - deixa as roupas mais limpas que os outros. caracterizava-se pela comunicação de uma vantagem diferenciada, única e especial do produto, através de mensagens fáceis de memorizar e reter, de modo a conferir à marca uma posição distinta no mercado (MITSURO, 2007, p.67).

No rádio e na TV esses métodos eram ainda mais evidentes, caracterizados pela linguagem simples e de fácil memorização de slogans, jingles e bordões, que, além de estabelecer claramente o benefício do produto, faziam com que as pessoas comprassem em função da lembrança.

Foram os próprios fabricantes que deram condições para que o varejo moderno se desenvolvesse, uma vez que precisavam de uma distribuição mais eficiente de seus produtos - o que os atacadistas não conseguiam - e de uma valorização dos novos lançamentos, que na maioria das vezes não sensibilizavam os pequenos comerciantes.

Enquanto a década anterior se caracterizava pelo foco na produção e em ganhar participação de mercado, pois tudo o que se era produzido tinha demanda, na década de 60 o foco das companhias era acelerar o consumo dos produtos, caracterizando uma estratégia de conquista. Surge, então, o Marketing, primeiramente como ferramenta 
de vendas e de pesquisa na busca pela preferência do consumidor (MITSURO, 2007, pg.138). No Brasil, esta nova ferramenta só chegaria junto com as multinacionais, fazendo dos anos 60 o apogeu do marketing de massa.

No início dos anos 60 o celofane era matéria-prima essencial para embalagem. Tinha boa aparência, permitia visualizar o conteúdo, podendo ser facilmente impresso. Entretanto não cumpria com a tarefa de conservação do produto por ser altamente higroscópico. ${ }^{6}$

Com a corrida espacial, uma porção de novos produtos que nasciam da tecnologia futurista, como os fast food, os refrigeradores, os freezers, os alimentos prontos congelados, começavam a influenciar profundamente os hábitos e os estilos de vida dos consumidores em todo mundo. As embalagens precisavam ser práticas e responder às necessidades de conveniência dos consumidores. Com isso, o design de

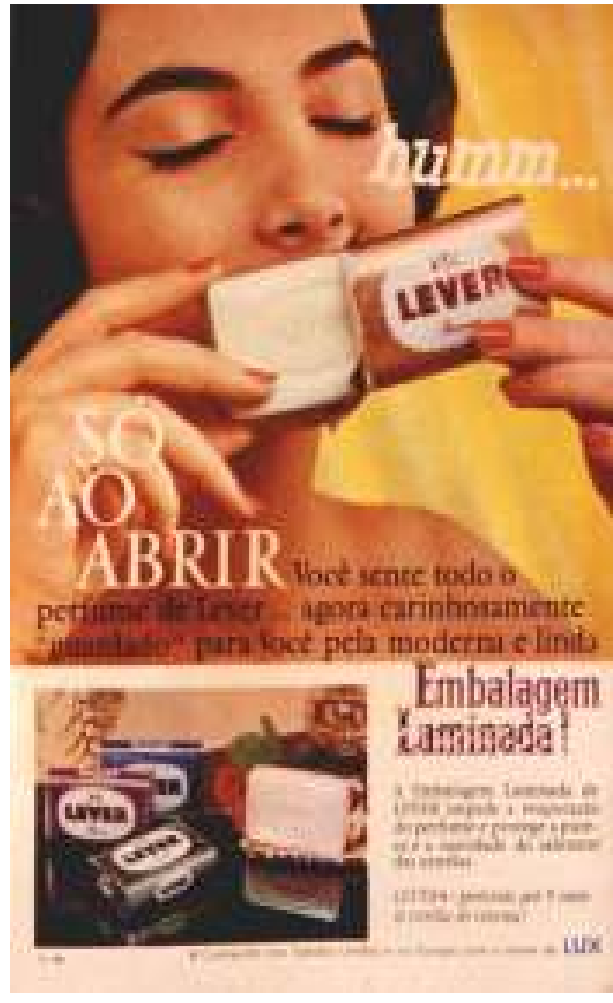

Figura 14: Nova tecnologia na embalagem do sabonete Lever, ajudando na conservação do perfume. embalagens começaria a se preocupar com a relação consumidorproduto, avaliando as nuances do uso e da interatividade. A embalagem passaria a ser encarada também como um facilitador no processo de consumo do produto.

Os estudos em ergonomia, que estavam sendo desenvolvidos durante toda a década de 50 , começam a ser base para uma série de mudanças nas embalagens; os plásticos também começavam a ganhar notoriedade e confiança viabilizando inúmeras inovações no setor. Com isso, tem início a era dos descartáveis que modificaram radicalmente o "mundo das embalagens".

Assim, além do desenvolvimento acelerado de matérias-primas

\footnotetext{
6 Higroscopia refere-se à capacidade de absorver água ou umidade. No caso do desenvolvimento de embalagens os materiais que possuem essa propriedade podem reduzir o prazo de vida útil do conteúdo em função da aceleração do processo de oxidação.
} 
e processos de fabricação, é na década de 60 que o design de embalagens começa a despontar no mundo como uma ferramenta de marketing.

Uma das primeiras obras a tratar do assunto foi The Silent Salesman (PILDITCH, 1961). Para o autor, muitas empresas poderiam vender mais mercadorias se suas embalagens fossem elaboradas para agradar as pessoas, sendo que, para tanto, as embalagens deveriam:

- Permitir a visualização do conteúdo;

- Permitir que o consumidor visse, comprasse, carregasse e usasse o produto facilmente, poupando trabalho;

- Proteger o produto, mas também serem fáceis de abrir, de fechar e de reutilizar se necessário;

- Ser fáceis de identificar para que o consumidor pudesse conhecer o produto, a marca, o preço e a quantidade ao mesmo tempo;

- Chamar a atenção e permitir uma rápida memorização;

- Ser capazes de ofertar quantidades diferentes, que preenchessem as necessidades dos distintos compradores;

- Permitir que o produto fosse consumido aonde o usuário desejasse, pensando na presença das embalagens não somente no supermercado, mas nas casas dos consumidores ou quaisquer outros lugares aonde pudessem ser utilizadas ou consumidas.

Além disso, caberia ao design de embalagens vender o produto não só nas lojas, mas também dentro dos lares e expressar o humor do produto, revertendo a preferência do consumidor em maiores lucros. Para tanto, seria imprescindível:

- Uma identificação dominante da marca;

- O nome claro e conciso do produto ou conteúdo;

- Um texto informativo e persuasivo; 
- Um design que transmitisse a mensagem desejada rapidamente e sem conflitos;

- Apelo psicológico que criasse convicção e produzisse a venda

Fica patente o despertar da importância do design da embalagem, responsável não só por facilitar o manuseio ou proteger e conservar o produto, mas como interface entre marca e consumidor a partir do momento em que se inicia uma preocupação com a comunicação no ponto de venda e com a interação consumidor-produto, seja durante a compra, durante o uso ou durante o acondicionamento ou consumo do produto nos lares.

Já a partir de 1960 que a indústria do plástico deu um grande salto rumo ao desenvolvimento, com a introdução das indústrias petroquímicas no Brasil. O PVC, o Polipropileno, o Polietileno e, posteriormente, o PET passaram a ser amplamente empregados na produção de diversos tipos de embalagens (CAVALCANTI; 2006).

Quanto ao design de embalagens, ainda cabia às agências de publicidade a prática estabelecida pelas Multinacionais instaladas no país. Somente no início dos anos 70 é que começariam a surgir os primeiros escritórios especializados em design de embalagens, atividade que se consolidaria a partir dos anos 80 .

Outra mudança para o mercado de higiene e beleza foi a permissão para venda desses itens em supermercados. Até então as vendas destes produtos aconteciam somente em farmácias e drogarias, visto que o auto-serviço se recusava a vendê-los por acreditar que, para tanto, deveriam contar com o atendimento de vendedoras especializadas.

Com isso, as empresas de produtos de beleza passaram a desenvolver embalagens cada vez mais bem elaboradas e sedutoras, pois não podiam mais contar com o serviço das promotoras de beleza, 
cabendo ao design de embalagens fazer a interface entre marca e consumidoras. $\mathrm{O}$ conceito de segmentação de produtos ${ }^{7}$ também ganhava força na indústria da beleza, sendo viabilizada pela embalagem. A marca Seda, por exemplo, foi a primeira a trazer produtos específicos para cada tipo de cabelo - cada embalagem promovia um tipo de xampu com atributos e benefícios distintos, dedicados às diversas necessidades de seus usuários.

A publicidade também cresceu e profissionalizou-se na década de 60 . Até esse momento, a publicidade se resumia ao trabalho de um redator e de um diretor de arte, ao texto e ao layout decorativo, não existindo um processo criativo. Com o surgimento do conceito de trabalho em equipe, que consistia na implementação de uma equipe formada por redatores, designers, fotógrafos e produtores, as peças publicitárias ganharam uma maior qualidade, profundidade e criatividade na concepção da mensagem. A evolução da publicidade caminhava paralelamente à evolução das sociedades, deixando de ser uma prática empírica e intuitiva para tornar-se uma atividade mais controlada e sistematizada, valendo-se de técnicas mais eficientes e precisas (VASQUEZ, 2006, p. 206).

Os novos produtos e marcas expostos nos supermercados ganhavam cada vez mais a credibilidade de seus consumidores, principalmente endossados pelo rádio e pela TV que Ihes emprestava uma boa imagem, de produtos de confiança e de qualidade. Mas essa "aura de perfeição" começaria a mudar a
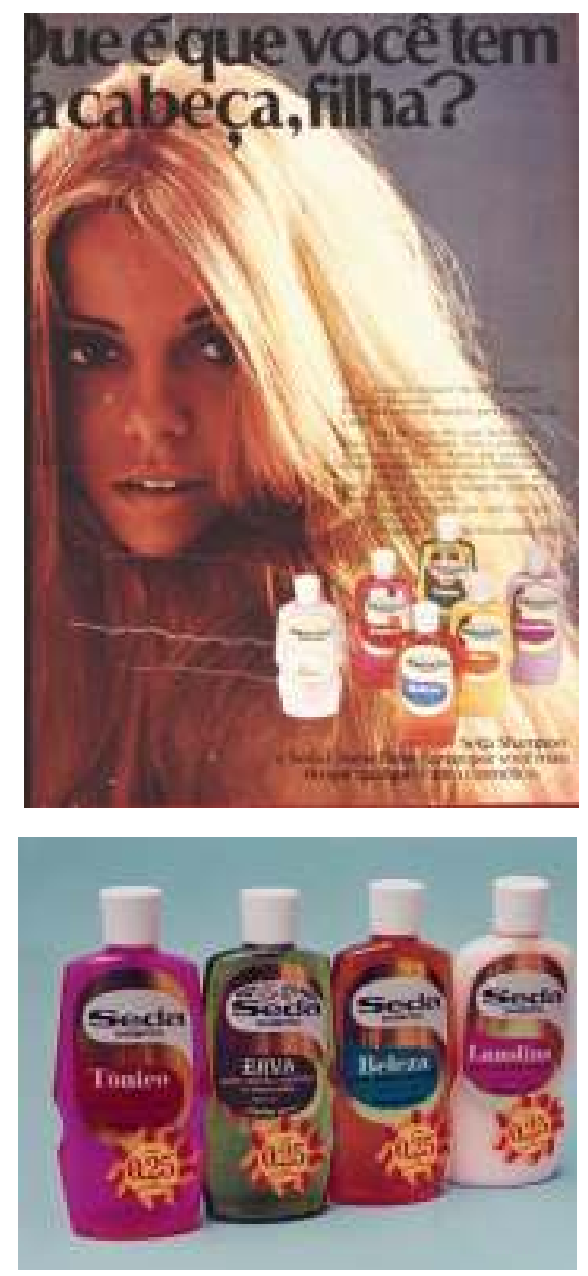

Figura 15: Anúncio da década de 60 e linha de produtos Seda. É possível perceber uma maior preocupação com a apresentação visual da linha de produtos - os rótulos são metalizados trazendo uma percepção de modernidade, ao mesmo tempo em que as cores e as formas sinuosas adotadas, tanto no design gráfico quanto no formato da embalagem, alinham-se à linguagem jovial da comunicação publicitária. Além disso, os frascos, de formato anatômico e em plástico transparente - uma novidade na época, permitiam a visualização do conteúdo, um sinal de qualidade do produto.

7 O conceito foi abordado pela primeira vez na década de 50, por Wendell Smith e consiste em "ver um mercado heterogêneo como um grupo de mercados homogêneos menores, em resposta à preferência por produtos diferentes entre os segmentos importantes no mercado. Isso é atribuído aos desejos dos consumidores ou usuários por uma satisfação mais precisa de seus desejos variados" (SMITH, 1956, p.6 apud MITSURO, 2007, p.138)". 
partir da década de 70 , o que se refletiu também no design das embalagens.

\section{3 - A multiplicação das embalagens nas gôndolas e as marcas próprias: 1970 a 1990}

A partir dos anos 70 , os publicitários começaram a se dar conta que o público não mais reagia tão bem aos argumentos estabelecidos pela abordagem da USP - Unique Selling Proposition, como nas décadas anteriores. Havia se instaurado uma fadiga relativa à propaganda ostensivamente racional que prometia além do que o produto efetivamente proporcionava.

Além disso, era preciso criar um maior valor para produtos com marca a fim de reduzir a primazia do preço sobre a decisão de compra, acentuando as bases de diferenciação entre os produtos e possibilitando negócios sustentáveis de mais longo prazo.

As agências começaram a incorporar psicólogos, sociólogos e economistas aos seus times, em busca de uma nova maneira de convencer ou seduzir os consumidores cada vez mais incrédulos. O foco transferiu-se para o entendimento das necessidades do consumidor e de suas expectativas.

Foram os conceitos de "ser" e de "parecer" que vieram a desbloquear esta situação. Subjacente ao entusiasmo crescente da posse e da compra por impulso, havia uma dinâmica que os psicólogos não demorariam em compreender e em utilizar - a necessidade de pertencer, de ser e de parecer dos consumidores. Todos queriam pertencer sem reservas e este mundo admirável do consumo (CHETOCHINE, 1999, p.17).

Identificaram-se os "estilos de vida" que tomariam o lugar da abordagem racional voltada à disseminação dos benefícios do produto. 
Para vender, posicionava-se a marca (ou produto) mais por sua contribuição psicológica, sua propriedade de "fazer do consumidor parte de um determinado grupo", do que pelo benefício proposto. Surge o conceito de Posicionamento, criado por All Ries e Jack Trout, estratégia cuja proposta era colocar o produto em um lugar privilegiado na mente do consumidor, num lugar vantajoso à concorrência.

"Verificou-se uma tendência geral de afastamento dos atributos do produto e uma aproximação do estilo de vida ou sistemas de valor" o consumidor faria suas escolhas baseadas em marcas que combinassem com seu estilo de vida ou que representassem um novo conceito estimulante, idealizado, aspiracional. (SHMITT; SIMONSON, 1998, p.31).

Além disso, associações únicas de marca começaram a se estabelecer por meio de características de produtos, nomes, embalagens, estratégias de distribuição e propagandas. Desse modo, a "marca" ganhava espaço em detrimento do "produto", deixando de ser somente uma identificação para ganhar status de "entidade".

As embalagens refletiam o momento a partir do uso de uma comunicação visual mais ousada, mais colorida, mais agressiva, passando a fazer, definitivamente, o papel dos vendedores das pequenas mercearias de outrora precisavam transmitir uma série de informações e evocar um conjunto de associações na mente dos consumidores através da comunicação de um estilo de ser. A embalagem evoluía na mesma direção das estratégias de marketing e a favor da

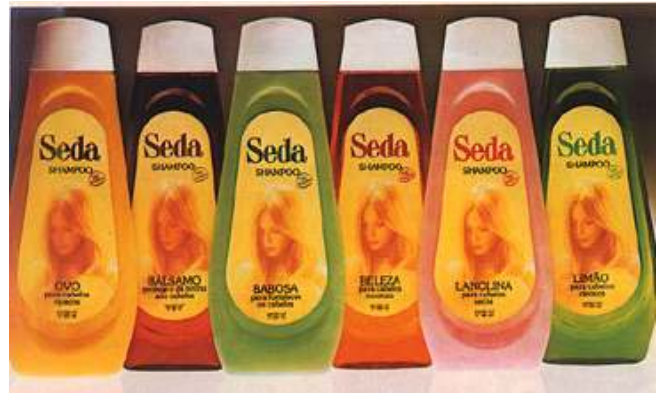

Figura 16: Linha Seda dos anos 70: diversidades de tipos expressos por embalagens que usavam a cor para diferenciar e destacar a marca. comunicação de marca.

A distribuição evoluía, o auto-serviço se expandia, as mídias se desenvolviam e o consumidor se adaptava. Os lançamentos se sucediam um após o outro e o marketing se especializava em compreender a psicologia do consumidor para melhor se comunicar com 
ele, introduzindo até mesmo novos conceitos que modificaram hábitos culturais fortemente arraigados.

Com o desenvolvimento do varejo, a competição ficava mais acirrada e as empresas começavam a se orientar para a tomada de participação da concorrência através do aprofundamento do entendimento da relação marca-consumidor. Afinal, mais e mais fabricantes passavam a ter acesso às tecnologias, garantindo uma percepção equiparada de qualidade. Os produtos começavam a ficar mais parecidos, gerando uma percepção de "comoditização" ${ }^{8}$ de categorias e produtos. Os apelos de vendas ou benefícios ofertados pelos produtos se tornavam menos diferenciados.

Assim, as embalagens tornavam-se veículos ainda mais importantes, não apenas de venda de produtos, mas sim de contextualização da marca a partir do momento em que passavam a transmitir uma mensagem global para o consumidor. As novas tecnologias de processamento, a descoberta de novos materiais e a otimização dos custos possibilitaram a criação de projetos mais inovadores de embalagens. A embalagem passava a ser vista como um instrumento de merchandising no ponto de venda.

Também foi na década de 70 que o rádio perdeu relevância para a TV, que se consolidou, a partir de então, como principal meio de comunicação de massa. O meio revista também se desenvolveu, ofertando títulos especializados e segmentados de acordo com públicos

\footnotetext{
${ }^{8}$ Segundo Martins e Blecher (1997), quase todas as marcas se nivelaram em qualidade (afinal a tecnologia, hoje, está ao alcance de todos), preço e benefícios, passando a ser tratadas pelos consumidores como "commodities", nesse contexto, interpretadas como um produto sem diferencial, encontrado em grandes quantidades e em qualquer lugar, cuja decisão de compra está mais vinculada ao preço do que às qualidades do produto ou à imagem da marca. Ainda segundo estes autores, a disseminação da percepção de commodities pelos consumidores é fatal para as empresas que construíram marcas ineficientes, pois os compradores tendem a decidir-se, cada vez mais, por produtos genéricos se não forem convencidos que um preço superior oferece benefícios relevantes em curto prazo.
} 
de interesse.

Com a crise do petróleo em 73, o Brasil, assim como o mundo, mergulhou em uma profunda instabilidade econômica. A inflação levou o poder de compra a despencar, refletindo em mudanças de hábito de consumo - os consumidores ficaram mais atentos a preços e à relação custo-benefício (CINQUENTA ANOS DE SUPERMERCADO NO BRASIL, 2002, p.73).

Os supermercados foram fortemente impactados pela situação e, na luta pela preferência dos consumidores, as grandes redes passaram a investir maciçamente em publicidade e preços baixos.

Em meio a esse contexto econômico e de "comoditização" das grandes marcas, em que o consumidor começava a questionar a equação de valor dos produtos no ponto de venda, em que a tecnologia não estava mais restrita a poucas empresas e onde o varejo necessitava aumentar sua rentabilidade é que surgem as private labels ou marcas próprias.

As "marcas próprias" eram produtos oferecidos pelos próprios supermercados sob a marca da loja e com preços muito

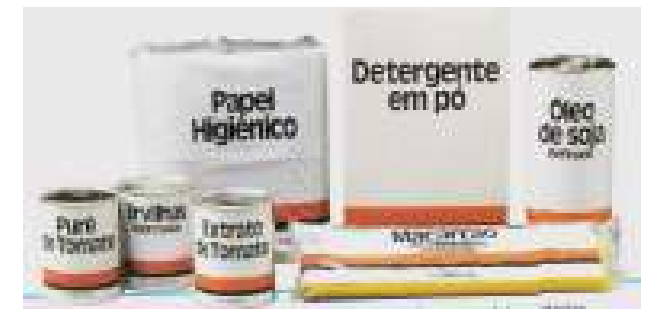
mais acessíveis ao consumidor. Eram negociadas grandes

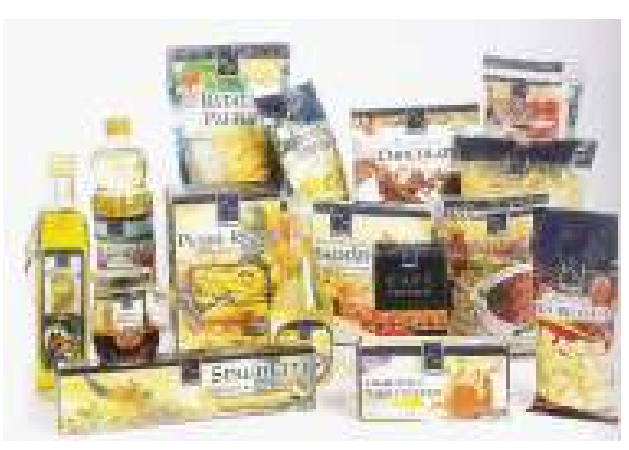

Figura 17: Marcas próprias nos anos 70 e atualmente: investimento em comunicação via embalagem para ganhar a confiança do consumidor. quantidades de produtos com os fornecedores, por vezes fabricantes de grandes marcas em busca de aumento de escala de produção. Além disso, não se fazia necessário o investimento em marketing e comunicação, o que reduzia drasticamente os custos.

Mas as marcas próprias só começaram a realmente fazer sucesso e a convencer os consumidores no final dos anos 90 , quando deixaram de posicionar-se como produtos genéricos e passaram a oferecer produtos com embalagens atrativas, de qualidade tão boa quanto àquela das marcas líderes do mercado (CAVALCANTI, 2006, p.141). 
As marcas líderes, em meio a esse cenário competitivo cada vez mais ácido, começaram a criar artifícios com o objetivo de garantir as metas de venda como a extensão das linhas de produtos em inúmeras variantes, a expansão das marcas para outras categorias de produto e a constante promoção de vendas. Ao mesmo tempo em que as embalagens viabilizaram a implementação das estratégias de segmentação e, com isso, a revolução das marcas, determinaram a multiplicação das opções nas gôndolas e conseqüente complexidade de escolha, exposição e de administração dos produtos acabados.

Apesar de alcançarem os objetivos de curto prazo aumentando as vendas, as estratégias de marketing convencional adotadas pela grande maioria das empresas estavam minando o poder das marcas a longo prazo ou o seu Equity, ${ }^{9}$ o que poderia comprometer o futuro e a saúde financeira das mesmas. Além disso, durante muito tempo a "emoção", a tentação da gôndola, o entendimento do comportamento do "comprador" no ponto de venda haviam sido negligenciados em detrimento do entendimento do "consumidor", abrindo um espaço ainda maior para as empresas de segunda linha ou para as marcas do varejo (CHETOCHINE, 1999, p.16).

Assim, na metade dos anos 80 , a publicidade e o marketing adotariam uma nova estratégia - o gerenciamento de imagem de marca aliado ao marketing no cliente ou trade marketing. O discurso de "ser", "parecer" ou "pertencer" já começava a ser rejeitado pelo mercado e a fazer parte do passado, em detrimento de uma "mentalidade de marca" e de uma maior preocupação com o ponto de venda. A embalagem passaria por novas adaptações na era das marcas fortes.

\footnotetext{
${ }^{9}$ De acordo com Aaker (1998), o Brand Equity refere-se ao conjunto de ativos e passivos ligados a uma marca, seu nome e seu símbolo, que se somam ou se subtraem do valor proporcionado por um produto ou serviço para uma empresa e/ou para os consumidores dela.
} 


\section{4 - O valor estratégico da embalagem na construção do Brand Equity: 1990 aos dias atuais}

A globalização e a evolução da tecnologia são as mudanças mais fundamentais pelas quais o mundo vem passando e que têm causado importantes alterações na base da economia, nos hábitos e atitudes de consumidores e, conseqüentemente, na dinâmica do consumo.

O avanço da tecnologia, também representado pela popularização da Internet, criou condições para a democratização da informação, equiparou a qualidade entre produtos, incrementou a concorrência e vem colocando, cada vez mais, o poder na mão do consumidor, que se tornou muito mais exigente, bem informado, mais interativo e ciente de seus direitos e poderes.

Segundo Lewis e Bridges (2004), os consumidores, a partir do final do século $X X$, passaram a adotar uma nova postura em relação ao consumo: ao invés de valorizar o produto por seus benefícios funcionais, facilmente reprodutíveis, começaram a apreciar produtos e serviços pelos benefícios adicionais ao seu valor de compra - prazer, recompensa, indulgência, felicidade, etc. A qualidade deixa de ser o diferencial de um produto, constituindo um benefício básico a ser percebido e experenciado.

Assim, a satisfação, que antes se detinha ao conceito de qualidade, hoje se conecta a um sentimento de auto-realização resultante da compra, que extrapola a qualidade física, funcional do produto em si. A satisfação passa a se refletir no quanto uma pessoa acredita que determinado bem possa valorizar-se em relação ao dinheiro pago ou o quanto pode oferecer de valor adicional àquele que o adquirir, numa dinâmica clara de "rentabilização" do dinheiro investido.

Se, por um lado, os consumidores ganham poder, por outro, os 
fabricantes fragilizam-se diante de um cenário econômico em profunda e constante transformação, principalmente, em função dos seguintes fatores:

- Mercados maduros: muitos produtos alcançaram seu estágio de maturidade e até mesmo de declínio no seu ciclo de vida, logo, o consumo se estabilizou e a única maneira de se conseguir aumento em vendas é aumentando a competitividade e reduzindo a participação de outras marcas, ou seja, não há mais espaço para todo mundo (CHETOCHINE, 1999);

- Proliferação de opcões: de acordo com Keller (2003), os portifólios de marca se tornaram mais complexos, tentando atingir o maior número de consumidores através da adoção de estratégias de segmentação. O resultado é que a marca hoje tem que ser identificada entre uma variedade de produtos similares, dificultando não só as decisões de compra do consumidor como também as decisões de investimento das companhias.

- Aumento do custo da inovação: com o aumento da competitividade, torna-se mais difícil lançar um novo produto e suportá-lo nas fases iniciais de introdução do ciclo de vida (CHETOCHINE, 1999; KELLER, 2003);

- Centralização do poder no varejo: de acordo com Kotler (2000), devido à concorrência acirrada, os custos de promoção do produto se elevaram, ao mesmo tempo em que as margens de lucro sofreram reduções drásticas. Neste cenário, os produtores passaram a depender fortemente do varejo que vem disponibilizando espaços cada vez mais limitados para exposição de produtos, quando não, pagos, ao mesmo tempo em que lançam 
marcas próprias que concorrem diretamente com as tradicionais por um preço infinitamente menor.

- Surgimento de marcas próprias ou private lables: ganhando relevância desde a década de 80 , quando as próprias indústrias, na busca por aumento de produção, deram início a um processo de fragmentação do valor de venda das marcas tradicionais. As marcas próprias consolidaram-se posteriormente, em função de situações recessivas de mercado, tirando proveito da falta de diferenciação ou comoditização das "grandes marcas" para estabelecerem patamares mais baixos de preço.

- Comoditização $^{10}$ ou baixa diferenciação: Muitas marcas nivelaram-se em qualidade, preço e benefícios, fazendo com que o consumidor passasse a decidir a compra em função do preço, o que tem sido fatal para inúmeras marcas;

- Erosão da mídia tradicional: ao mesmo tempo em que o custo dos investimentos em mídias de massa cresce, as audiências, em contrapartida, diminuem visto que se fragmentam, impactadas, principalmente, pelo crescimento de canais independentes, pelo comportamento de zapping, pelo crescimento da importância da TV a cabo ou satélite, bem como pela mudança de perfil e hábitos dos consumidores. Emergem, portanto, as mídias não

\footnotetext{
10 Segundo Martins e Blecher (1997), quase todas as marcas se nivelaram em, preço e benefícios, passando a ser tratadas pelos consumidores como "commodities" - nesse contexto, interpretadas como um produto sem diferencial, encontrado em grandes quantidades e em qualquer lugar, cuja decisão de compra está mais vinculada ao preço do que às qualidades do produto ou à imagem da marca. A disseminação da percepção de commodities pelos consumidores é fatal para as empresas que construíram marcas ineficientes pois os compradores tendem a decidir-se, cada vez mais, por produtos genéricos se não forem convencidos que um preço superior oferece benefícios relevantes no curto prazo.
} 
tradicionais, as ações no ponto de venda, as mídias interativas, digitais, os eventos, patrocínios, promoções, entre outras alternativas diferenciadas de comunicação e meios (KELLER, 2003).

Assim, o mercado, extremamente competitivo e pouco diferenciado, acaba muitas vezes optando por batalhas focadas em preço na busca pela atenção desse consumidor, que imerso em um mundo de opções multiplicadas, excesso de informações e falta de tempo torna-se cada vez mais distante da mira das ações de marketing e com um comportamento pouco previsível.

Todas estas mudanças promoveram e vêm promovendo uma transformação na maneira como os fabricantes se orientam, se relacionam e como se colocam perante a nova economia, afinal, o modo com o qual os consumidores interagem com marcas e produtos, suas motivações e seus interesses não são mais os mesmos.

Como se conectar com o novo consumidor? Como se diferenciar, de modo relevante, em meio a uma avalanche de opções que se estabelece a cada dia? Como aumentar o valor percebido da marca?

Se no século passado bastava que a publicidade enaltecesse as virtudes do produto ou de seu usuário, hoje os olhares se voltam para o ponto de venda, em que compreender quais os fatores que levam à escolha de uma determinada marca, quando todas são possíveis, e qual o poder de influência que as embalagens exercem no momento da decisão da compra, onde todas se misturam, pode fazer a diferença para as companhias (CHETOCHINE, 1999, p.16).

Em resposta a esses desafios, já na década de 90, surgiram alguns novos conceitos ligados ao gerenciamento das marcas como imagem de marca, reconhecimento de marca, identidade de marca, etc, que começaram a se estabelecer a partir do século $\mathrm{XXI}$. 
De modo geral, todas essas novas ferramentas de marketing estavam ligadas à necessidade de se investir na sustentabilidade das marcas e na construção de "marcas fortes", com o intuito de gerar um maior valor a longo prazo, tanto para a companhia quanto para o consumidor. Era necessário criar associações de marca capazes de definir posições de mercado, de persistir durante longos períodos de tempo, de resistir à concorrência agressiva e de gerar interesse a um consumidor cada vez mais saturado e incrédulo.

Construir uma marca "forte" significa fortalecer seu Brand Equity $^{11}$, uma prática que demanda continuidade e consistência. Isso porque o valor da marca necessita de tempo para ser desenvolvido, ser sedimentado através de ações de longo prazo, já que a marca é um ativo dinâmico, formado por associações mentais que se constroem a cada dia na mente de seus consumidores.

Uma marca forte proporciona valor tanto para o consumidor, que se reflete em confiança, satisfação e redução do risco de compra, quanto para a empresa, na forma de retenção de usuários - lealdade de marca, de atração de novos consumidores, de maior lucratividade, de barreira à concorrência e facilidade no relacionamento com os canais de distribuição.

E é no âmbito da construção de marca que a embalagem vem ganhando relevância, migrando de um conceito fortemente vinculado ao

\footnotetext{
${ }^{11}$ A definição do Brand Equity é trazida por diversos autores, dentre os quais pode-se destacar aquela trazida por Keller (2003, p.42), em que o Brand Equity pode ser definido em termos dos "efeitos de marketing que podem ser atribuídos exclusivamente à marca". Essa definição se insere naquela trazida por Aaker (2003, p.16), na qual o Brand Equity é "um conjunto de ativos e de passivos ligados a uma marca, que se somam ou se subtraem do valor proporcionado por um produto ou serviço, para uma empresa e/ou para seus consumidores". Para uma maior clareza de definições, convém distinguir "valor da marca" e "ativos da marca". Em Kapferer (2003, p.29), os "ativos" se relacionam à percepção que os consumidores têm da marca, enquanto que o "valor da marca" refere-se à quanto esses ativos representam monetariamente para a empresa.
} 
produto, para um conceito mais abrangente e estratégico: o de elemento de comunicação de marca ou expressão marcaria.

Mais do que funcionalidade e visibilidade a embalagem, hoje, deve maximizar as sementes lançadas nas décadas de 50 e 70, exercendo o papel fundamental de criar associações fortes, favoráveis e exclusivas que elevem o valor da marca; mais do que contribuir com o "P de Produto" no composto de marketing, deve se estabelecer como um elemento de comunicação, contribuindo para a promoção da marca, para o fortalecimento do seu patrimônio e para a viabilização da estratégia de marketing da atualidade: o Branding. ${ }^{12}$

Enquanto elemento de comunicação de marca, a embalagem pode contribuir para o fortalecimento do Equity porque: 1) configura um ponto de expressão comunicativa da marca, capaz de criar associações positivas; 2) constitui um ponto de experiência com a marca, influenciando percepções; 3) é um elemento de materialização da marca já que traduz sua essência e visão em realidade (MOZOTA, 2003, p.198).

Marcas fortes se caracterizam pela capacidade de entrega de valor adicional aos clientes e à própria empresa e a embalagem constitui um recurso precioso na materialização desse valor, pois:

- Para os consumidores: embalagens efetivas proporcionam valor na forma de identificação da origem do produto; de melhor qualidade de manuseio, uso, armazenamento e descarte do produto; de dispositivos simbólicos que permitem aos consumidores projetarem sua auto-imagem,

\footnotetext{
${ }^{12}$ Branding constitui o "conjunto de atividades que visa otimizar a gestão das marcas de uma organização como diferencial competitivo." (MACHADO, 2006). Gerenciamento de Marcas ou Branding nada mais é que dotar produtos e serviços do poder do Brand Equity, um conceito que denota a importância do papel das marcas nas estratégias de marketing e que tem como objetivo guiar a compra e construir relacionamentos duradouros com os consumidores (KELLER, 2003).
} 
conferindo-Ihes um status diferenciado; na forma de conveniência, prazer e satisfação de compra;

- Para os fabricantes: embalagens efetivas proporcionam maior eficiência no gerenciamento do portifólio da marca (segmentações, extensões para novas categorias e mercados, reposicionamento); constituem um recurso passível de proteção legal, estimulam as vendas, influenciam na imagem da marca, contribuem para a fidelização; constituindo, portanto, fontes de vantagem competitiva para as empresas.

Assim, o design de embalagens deve desenvolver, na "economia das marcas fortes", o papel fundamental de despertar a preciosa atenção do consumidor, criando uma relação de atração e encantamento; comunicar benefícios e valores da marca e propiciar uma experiência positiva com a mesma. É, dessa forma, que a embalagem poderá contribuir no fortalecimento do Equity, resultando em uma vantagem competitiva real para as companhias.

De modo que, constituem os maiores desafios para o design de embalagens:

- "Edificar uma roupagem exclusiva e de propriedade da marca, um design que promova uma diferença tangível frente aos concorrentes e que se comunique de maneira poderosa com o consumidor alvo" (GOBÉ, 2002, p. 279);

- Gerenciar com propriedade este importante signo marcário, potencializando a comunicação da marca e a construção do Equity a partir de uma abordagem projetual. 


\begin{tabular}{l} 
Funções da Embalagem \\
Antes de 1950 \\
\hline
\end{tabular}

Proteção: A embalagem deveria ser resistente o suficiente para proteger o conteúdo de possíveis danos ocasionados no transporte, manuseio, estocagem bem como protegê-lo contra as intempéries Identificação: A embalagem deveria identificar o fabricante do produto e fornecer informações mínimas sobre a procedência do produto.

\section{De 1950 a 1970}

Informação: A embalagem começava a dividir o papel com o vendedor, levando informações sobre os atributos do produto, sua qualidade, bem como quais benefícios o consumidor teria adquirindo a mercadoria.

Conservação: As embalagens deveriam prolongar a vida útil ou prazo de validade do produto, uma vez que protegeriam do ar, da umidade, evitando, assim, a oxidação do conteúdo.

Manuseio: Deveria facilitar o transporte, a armazenagem, a separação e a reposição no autoserviço.

Apelo: Iniciava-se uma preocupação com o design da embalagem a fim de atrair a atenção do consumidor no ponto de venda, influenciando no processo de decisão de compra através do impacto visual.

Promoção: Além de atrair a atenção do consumidor, a embalagem deveria comunicar claramente a finalidade do produto e ter grande visibilidade para destacar-se entre uma variedade de outras marcas utilizando artifícios como a cor, o formato, o tamanho, etc.

Posicionamento: A embalagem deveria apresentar um conceito visual que auxiliasse uma marca a se distinguir das demais, denotando uma vantagem única e motivando o público a escolhê-la. Deveria auxiliar o consumidor a situar a oferta perante o mercado.

Ergonômica: A embalagem deveria promover a melhor solução para sua função de uso; deveria ser segura, proporcionar um manejo correto, confortável, facilitar tarefas, poupar tempo, ser facilmente acondicionada e utilizar os materiais mais indicados para isso.

\section{A partir de 1990 e desafios para o século XXI}

Comunicação de marca: Edificar uma roupagem exclusiva e de propriedade da marca, um design que promova uma diferença tangivel frente aos concorrentes e que se comunique de maneira poderosa com o consumidor alvo

Figura 18: Funções das embalagens ao

longo dos tempos.

Tendo conhecido um pouco do seu desenvolvimento em função dos

principais acontecimentos mercadológicos e sócio-culturais do século

$\mathrm{XX}$, faz-se necessário compreender, de modo mais aprofundado, suas

atribuições, potencialidades, impactos na comunicação e na formação

de imagem da marca na atualidade. 


\section{Capitulo 2}

Embalagem, marca e integração

Desde que a embalagem começou a desempenhar uma função comercial no começo do século $\mathrm{XX}$, o papel mediático é parte integrante de suas atribuições, em maior ou em menor grau. Afinal, com ou sem o apoio da publicidade, a embalagem sempre foi, em algum momento, o veículo de comunicação inevitável de um fabricante, de um produto ou de uma marca para um consumidor.

A marca foi gradativamente valorizada nas embalagens ao longo dos tempos e, aos poucos, foi migrando de um instrumento de identificação do fabricante ou do produto para uma espécie de ferramenta simbólica da marca.

Suas funções junto à marca foram evoluindo, hora funcionando como uma interface comunicativa e funcional junto ao consumidor, hora viabilizando novas estratégias de marketing.

Constitui, entretanto, seu maior desafio, a maximização das sementes lançadas nas décadas de 50 e 70, através de uma sofisticação de seu pensamento como objeto de comunicação visual, equiparado ao seu caráter e valor estratégicos, processo que demanda integração e alinhamento ao discurso de marca e que será abordado a seguir.

\section{1 - A embalagem e a comunicação de marca}

Associações de marca são construídas na mente do consumidor a partir da recepção de estímulos e informações de todo tipo de natureza. Associações são criadas por qualquer elemento que estabeleça uma ligação com a marca: características e benefícios dos produtos, seu design, sua embalagem, sua propaganda, seus canais de
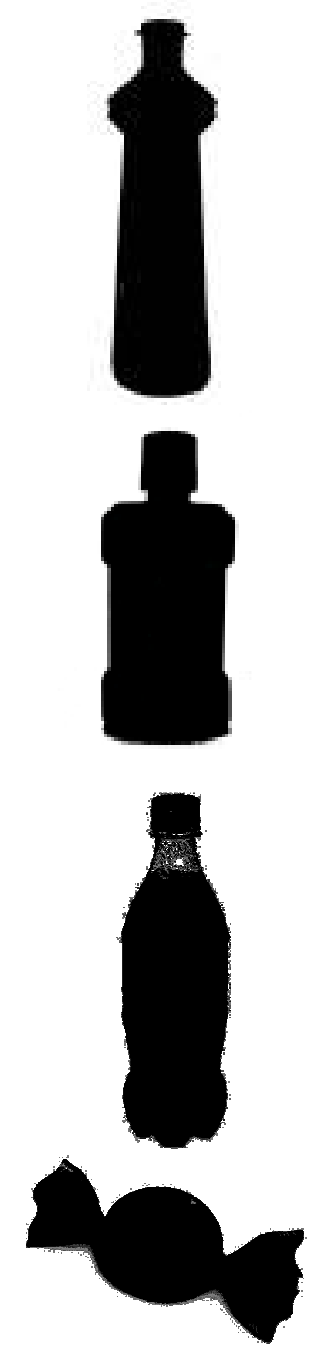

Figura 19: $O$ formato da embalagem pode determinar tanto a categoria de produtos quanto a marca, se consistir em um design memorável e até mesmo exclusivo. As silhuetas acima representam, respectivamente, um limpador multiuso, cujo design foi inaugurado $e$ exclusivo do limpador Veja; o enxaguador bucal Listerine; o refrigerante Coca-Cola; e um bombom, cuja primeira associação poderia ser a embalagem de Sonho de Valsa. 
distribuição, etc.

Ao ter um primeiro contato com a embalagem de um produto, por exemplo, um indivíduo pode armazenar algumas primeiras impressões. Em um segundo contato com a propaganda desse produto, ele poderia somar outras impressões ao contato anterior, formando uma rede associativa de conhecimento sobre determinada marca.

Associações são livres, não constituindo uma função previsível, já que também estão relacionadas ao repertório individual. Por mais que se tente prever um resultado perceptual, é impossível garantir que a mensagem comunicada será igual para cada receptor.

Entretanto, no âmbito do planejamento visual de uma embalagem, a imagem não configura um elemento de todo subjetivo, visto que pode ser controlada para gerar os efeitos comunicativos desejados, segundo objetivos previamente estabelecidos.

Nesse planejamento se insere o design como processo orientador do projeto, seleção, programação e organização de uma série de fatores e elementos com o objetivo de desenvolver embalagens efetivas tanto em seus aspectos funcionais, quanto na produção de mensagens visuais com o propósito de afetar a percepção, a atitude e o comportamento das pessoas, melhorando a qualidade de vida dessas (FRASCARA, 2000).

E para que as associações geradas pela embalagem sejam eficazes na construção do Brand Equity, designers e gestores de marketing devem atentar para a escolha de recursos visuais que, na medida do possível, façam da embalagem um elemento de identidade de marca memorável, exclusivo, favorável e estético ( KELLER, 2003; AAKER, 1998). Vejamos abaixo um maior detalhamento desses aspectos:

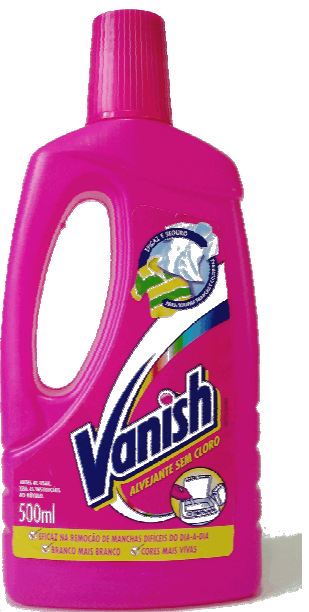

Figura 20: A linha Vanish de cuidados com a roupa desenvolveu um design que faz da embalagem algo memorável e exclusivo. A cor rosa, não explorada até então pela categoria de produtos, se tornou um elemento de identidade visual capaz de gerar forte impacto, visibilidade e diferenciação no ponto de venda, além de facilitar a lembrança de marca.

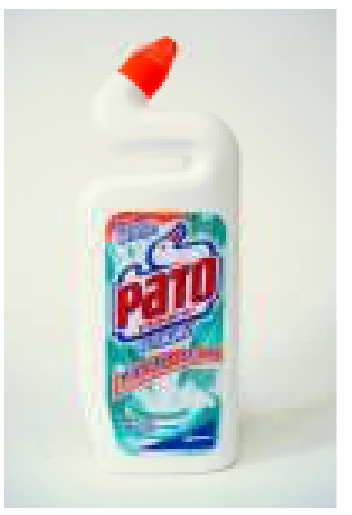

Figura 21: $A$ embalagem de Pato Purific constitui um exemplo de embalagem memorável e exclusiva, dado sua forma diferenciada que também referencia a marca do produto, além de favorável, já que ressalta os atributos da marca - eficácia até mesmo nos lugares de mais difícil alcance. 


\section{1) Memoráveis:}

Embalagens são memoráveis quando seus elementos gráficos e formais, como cores, formas, ilustrações, fotos e/ou o resultado de suas combinações, são capazes de gerar uma solução de design fácil de ser memorizada, fácil de ser relacionada com a categoria de produtos ou com a marca e fácil de ser compreendida.

\section{2) Exclusivos:}

O design da embalagem é exclusivo quando possui características capazes de distinguir e posicionar a marca em relação à concorrência. Designs exclusivos, além de gerar visibilidade e impacto no ponto de venda, são mais facilmente protegidos do ponto de vista legal, criando uma vantagem competitiva para a marca.

\section{3) Favoráveis:}

O design da embalagem é favorável quando é capaz de posicionar a oferta da marca e ressaltar as razões de compra de maneira crível e relevante para o consumidor. Um design de embalagem favorável cria significado relevante para a marca e possibilita a produção de reações e julgamentos positivos por parte dos consumidores, que tendem a se reverter em credibilidade e consideração de compra.

\section{4) Estéticos:}

Marc Gobé (2002) afirma que a revolução digital nos distanciou da realidade física, palpável e acelerou nossas vidas nos afastando do prazer da experiência sensorial tão necessária aos sentidos e às emoções, de modo que as experiências com um produto ou com uma determinada marca tornam-se cada vez mais relevantes na atualidade, podendo influenciar o poder de decisão dos indivíduos de forma muito mais profunda através do resgate do prazer estético.

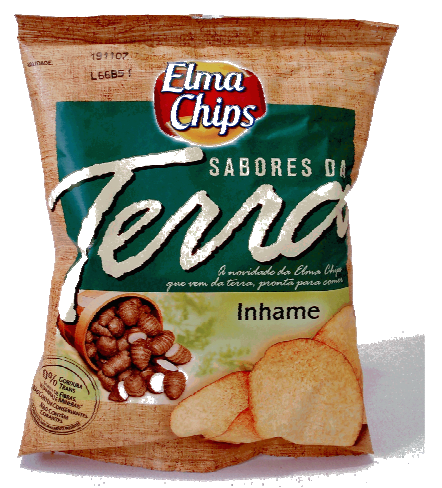

Figura 22: A linha Sabores da Terra da Elma Chips tem um design favorável, que ressalta o posicionamento do produto: a textura de fundo da embalagem, que remete aos sacos de estopa para colheita, bem como a ilustração realista da cesta de inhames, ressaltam o uso de ingredientes naturais, quase que recém colhidos, na produção do produto, além de conferir um apelo brasileiro regionalizado à marca.

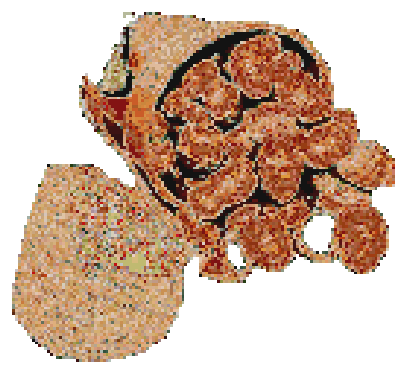

Um carimbo, semelhante ao usado para identificação da procedência das sacas, fornece informações sobre as características do produto, fornecendo um atestado de qualidade ao consumidor. 
Isso acontece porque os consumidores podem criar associações de produto que vão além de aspectos funcionais para considerações mais estéticas relacionadas ao tamanho, ao formato, aos materiais e às cores aplicadas ao produto, que no mercado de bens de consumo imediato se traduzem na embalagem.

O termo estética vem da palavra grega aisthetikos, que significa "perceptivo através do sentidos". Foi empregada na Filosofia e, posteriormente, nas Belas-Artes. Já no campo design pode ser entendida como sendo a "forma como resultante" ou a "forma como diferencial" (SCHMITT; SIMONSON, 2002).

Logo, a construção de imagem de marca pode também depender de aspectos sensoriais como a aparência de um produto ou da embalagem, do toque e até mesmo do seu cheiro ou som (KELLER, 2003, p.83).

A forma ou estética de uma embalagem pode contribuir para o sucesso da marca de diversas formas, seja afetando a percepção do produto em si, ganhando a atenção e preferência do consumidor, criando diferenciação em relação à concorrência, estabelecendo o posicionamento da marca ou mesmo gerando prazer - os produtos mais bem sucedidos oferecem valor estético e utilitário para o consumidor.

Segundo Sandra Souza (1997), a forma, no âmbito do Design, ganha um significado que vai além do contorno ou do desenho da coisa. A forma é o modo como o Design se expressa, interface tangível e sensorial do usuário para com o produto de Design, seja este um objeto ou uma informação. O Design de Embalagens desempenha, portanto, um importante papel na formação de associações que podem ser decisivas na definição da compra e na construção do Equity da marca.

Os principais elementos que podem influenciar a percepção estética da embalagem e, por conseqüência, a imagem da marca, são: forma, tamanho, materiais, acabamentos, texturas, cor e elementos

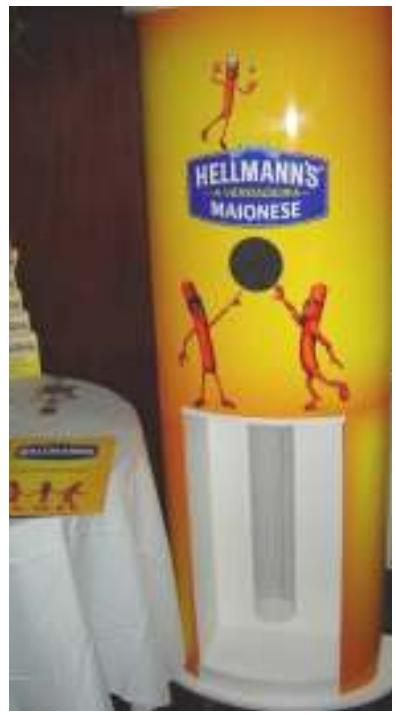

Figura 23: Exemplo de construção de imagem através da embalagem: Estratégia: comunicar ao consumidor e aos diversos canais envolvidos a substituição do frasco de vidro tradicional para o frasco PET reforçando " o mesmo sabor da verdadeira maionese em embalagem inquebrável".

Speech da promotora:

- Saudação.

- Já conhece a novidade que Hellmann's trouxe para a Senhora?

- Então vamos conhecê-la!

- Olhe por esta abertura e diga o que está vendo.

- Notou alguma diferença?

- Agora coloque a mão aqui. E agora notou a diferença?

- Isso mesmo! Hellmann's agora tem nova embalagem PET. A Sra pode dar um passo para trás?

- Promotora puxa alavanca, o pote de Hellmann's cai no chão.

- Hellmann's continua com o mesmo sabor, agora em nova embalagem inquebrável.

- É mais praticidade e segurança no seu dia-adia.

- Vai levar quantas hoje? 
gráficos (ELWOOD, 2004; PEREZ, 2004; GOBÉ, 2002).

\section{a) Forma e tamanho:}

A forma é um elemento estético de grande potencial perceptivo no processo comunicativo. Apesar de ainda pouco explorada, é a partir do toque que $o$ ato de posse se consuma, que é possível sentir um produto, gerar interação e envolvimento.(GOBÉ, 2002)

De fato, as formas são interessantes elementos estéticos, pois trabalham não só a dimensão tátil, mas a visual-simbólica também.

Na dimensão tátil, a forma da embalagem deve ser ergonômica, e promover segurança, funcionalidade, praticidade e conforto. É na dimensão de contato que se estabelece uma relação física entre produto e usuário.

$\mathrm{Na}$ dimensão visual-simbólica é possível avaliar a forma da embalagem segundo seu tamanho, sua escala, simetria, angularidade e direção, e como cada uma dessas propriedades influencia a percepção do indivíduo sobre o produto e sobre a marca (DONDIS, 2003).

Embalagens que inovem em forma ou em tamanhos podem identificar e diferenciar o produto no ponto de venda, criar associações de produto e de marca, facilitar o manuseio, uso, transporte e armazenamento, indicar uso individual ou familiar, indicar economia,

Figura 24: Linha de águas Ouro Fino: portifólio de embalagens extenso para atender os mais diversificados públicos: galões e embalagens de $1 \mathrm{~L}$ a $2 \mathrm{~L}$ para uso familiar, copos, garrafas de 200 a $500 \mathrm{ml}$ para consumo individual, embalagem com bico dosador para prática de esportes, embalagens que vão à mesa.. melhorar o aproveitamento de produto, etc.. O formato da embalagem, quando exclusivo, constitui um elemento de identidade de marca.

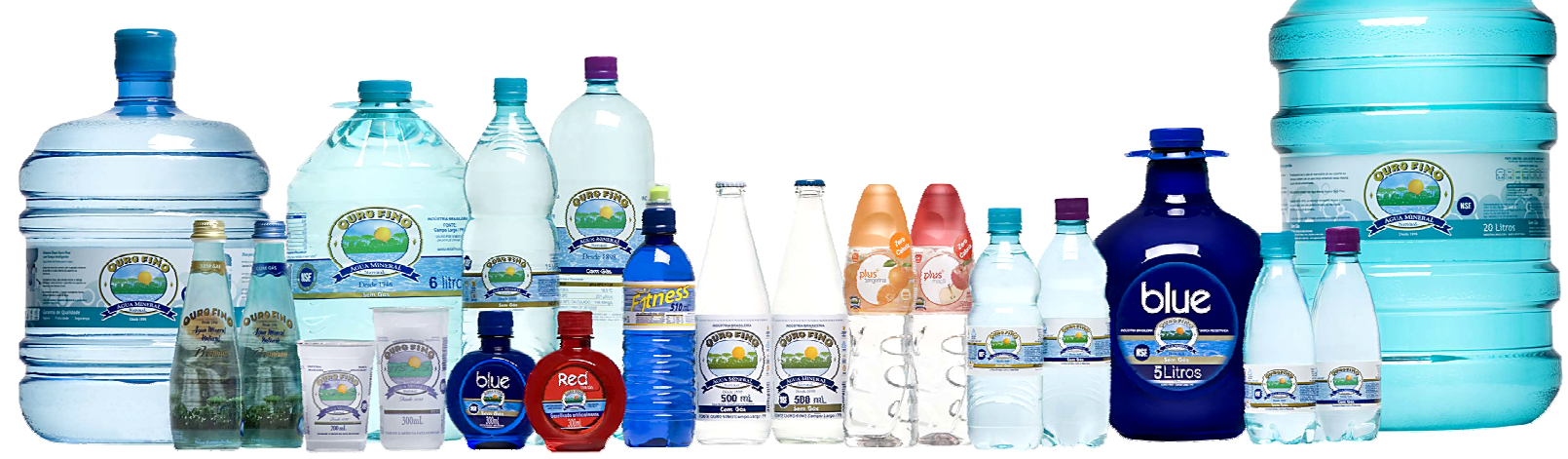


Entretanto, poucas são as marca que detêm um design estrutural exclusivo, principalmente considerando-se os altos custos para desenvolvimento de ferramental de produção - a maioria das empresas acaba optando por investir em design gráfico. Além disso, o design estrutural de embalagens é mais difícil de patentear e proteger legalmente dada a dificuldade em avaliar o que é um design original ou simplesmente adaptação de um projeto pré-existente.

O desodorante Rexona Teens traz uma proposta única e inovadora, desenvolvida especialmente para as necessidades das mulheres na fase da adolescência. As adolescentes começam a desenvolver uma vida social mais ativa, onde o controle dos odores da transpiração passa a ser percebido como um cuidado fundamental. A rotina, repleta de atividades como escola, cinema, cursos, viagens, etc, demanda um produto que acompanhe diariamente essas consumidoras, fornecendo a segurança que necessitam, de forma individualizada já que o tema transpiração é extremamente pessoal. O design reduzido da embalagem Rexona Teens se adequa à essas necessidades, estimulando o uso individual, trazendo maior conveniência, uma vez que pode ser facilmente carregado na bolsa, acompanhando a consumidora aonde quer que ela vá e propiciando uma diferenciação clara em relação às demais versões da linha Rexona, o que cria uma maior afinidade junto ao público alvo. Já do ponto de vista de possíveis associações, produtos menores são mais delicados e femininos, como as adolescentes.

\section{b) Materiais, acabamentos e texturas}

A textura também é um elemento estético bastante rico sensorialmente. Pode ser inerente a um determinado material ou ser simulada gráfica ou formalmente. Segundo Clotilde Perez (2004), "a textura contém qualidades ópticas, térmicas e táteis e, portanto, carrega valores culturais e simbólicos decorrentes de suas qualidades".

O uso de texturas ou materiais que tragam sensações táteis distintas nas embalagens pode ser um interessante recurso para complementar a experiência perceptiva com a marca.

Alguns materiais são capazes de criar associações como calor, frescor, limpeza, leveza, resistência, naturalidade/artificialidade, temporalidade e até mesmo nobreza. Embalagens em alumínio, latão ou
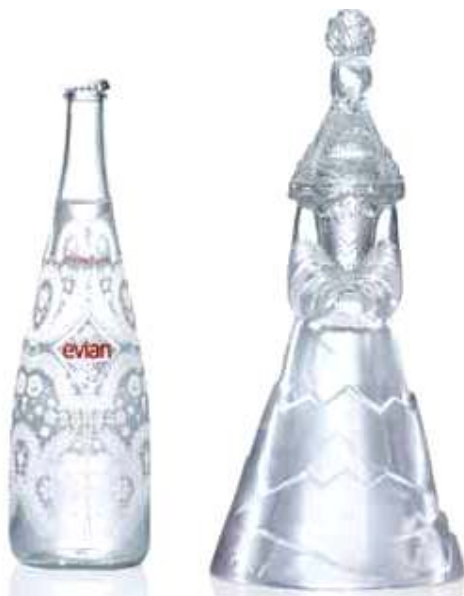

Figura 26: Edição especial de embalagens Evian, assinadas pelo estilista Christian Lacroix. A versão prêtà-porter parece coberta por uma renda com detalhes que lembram cristais de gelo - uso da textura reforçando os atributos de pureza e frescor da marca. 
com acabamentos metalizados ou prateados transmitem a sensação de frio, remetem à modernidade e à tecnologia, enquanto que acabamentos dourados, por exemplo, remetem ao ouro, revelando nobreza, sofisticação, luxo. Embalagens em vidro ou transparentes, emprestam ao produto uma imagem de pureza e credibilidade, afinal, é possível ver e julgar o conteúdo.

Além disso, o emprego de materiais adequados no design das embalagens pode contribuir ergonomicamente para um melhor uso, bem como reforçar conceitos ou temas de marcas ou benefícios de produtos através de associações. Os materiais reciclados utilizados nas embalagens da linha Ekos, por exemplo, ajudam a reforçar o conceito de sustentabilidade, defendido pela marca Natura.

\section{c) Cor:}

A cor constitui um elemento estético de valor inestimável no processo comunicativo, sendo amplamente utilizada para atrair a atenção, significar, agrupar, separar, promover sensações físicas e emocionais.

A cor é o principal elemento que as pessoas identificam em uma embalagem, caracterizando, em alguns casos, a linguagem da categoria de produtos. As cores podem criar associações diversas para a marca, além de propiciar visibilidade e diferenciação.

Varia em matiz que é a cor em si, em saturação, que se refere à pureza da cor, e em luminosidade, ou seja, à gradação tonal do claro ao escuro, gerando um sem-fim e possibilidades combinativas.

As marcas podem fazer da cor um forte elemento de identidade. Se consistentemente utilizada, torna-se uma assinatura da marca, parte integrante de seu Brand Equity, podendo até mesmo ser protegida legalmente: o vermelho da Coca-Cola e o amarelo de Kolynos são bons exemplos.

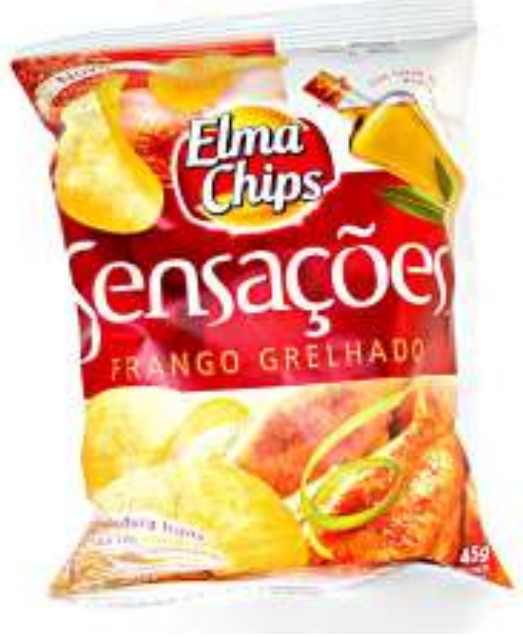

Figura 27: A linha de snacks Sensações da Elma Chips, faz um excelente uso da textura aplicada á embalagem de produto - o toque acetinado proporciona uma experiência sensorial diferente, potencializando o conceito do produto e aumentando as expectativas com relação ao sabor $e$ aroma.

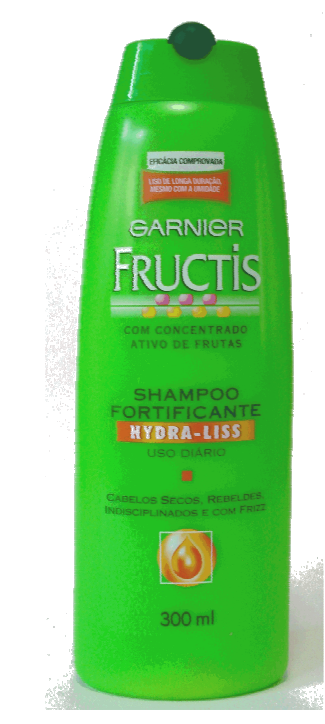

Figura 28: A linha de produtos para cabelo Fructis Garnier possui uma cor única verde limão, que facilita o reconhecimento no ponto de venda, contribui para a lembrança de marca e se alinha ao conceito do produto: xampus à base de frutas cítricas. 


\section{d) Elementos gráficos:}

Elementos gráficos auxiliam na comunicação de atributos, benefícios, do posicionamento e no desenvolvimento de uma identidade de marca. Quanto mais memoráveis, exclusivos e favoráveis, mais efetivos serão.

Logo, o uso de recursos visuais no design de embalagens só é efetivo e agrega valor ao Brand Equity quando se conhece o poder de significação destes recursos e quando são controlados de modo a contribuir no desenvolvimento das seguintes etapas, imprescindíveis no processo de construção de marcas fortes (KELLER, 2003; AAKER, 1998):

- Tornar a marca conhecida através de uma Identidade memorável;

- Criar significado e relevância para a marca através de um posicionamento exclusivo;

- Criar imagem, reações e sentimentos favoráveis através de sua personalidade;

- Criar familiaridade e relacionamento promovendo a Lealdade de Marca.

A seguir veremos, detalhadamente, como o design de embalagens pode influenciar cada uma dessas etapas:

\section{2 - Embalagens para gerar Conhecimento de Marca}

A Identidade da Marca é a maneira pela qual a estratégia da marca e os benefícios ao consumidor se tornam visíveis; a soma de todas as características tangíveis e intangíveis da marca, seus elementos de identificação e todas as manifestações e expressões, que fazem dessa algo único e exclusivo (MOZOTA, 2003, p.98).

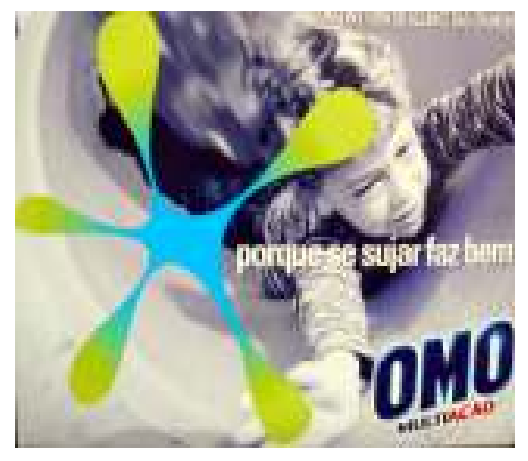

Figura 29: O splash de OMO é um exemplo de elemento gráfico que reforça o posicionamento, relacionando-se diretamente com a "mancha" ou a "sujeira", mas de uma maneira divertida, porque $O M O$ acredita que "se sujar faz bem". 
A Identidade da Marca reflete a contribuição de todos os elementos da marca ou elementos de identidade, ou ainda, "expressões marcárias" (PEREZ, 2004), ao conhecimento e à imagem da marca. elementos da marca são mecanismos exclusivos da marca que a identificam e a diferenciam e que são capazes de criar conhecimento, associações, estima e sentimentos, afetando a qualidade percebida e a lealdade.

A embalagem constitui um importante elemento de identidade, capaz de aumentar os níveis de conhecimento e de construir significado e sentido para marca, alimentando seu inventário imagético, simbólico e sensorial, ou seja, seu Equity. (KELLER, 2003; PEREZ, 2004).

Isso porque o aspecto físico do produto está na base da marca, no seu valor agregado tangível (KAPFERER, 2003, p.91-102). Assim, ao pensar em produto no mercado de bens de consumo imediato, uma das mais fortes associações que os consumidores desenvolvem se relaciona à aparência da embalagem, visto que é o estímulo real com o qual se confrontam no ponto de venda ou durante o uso, chegando, em muitos casos, a ser impossível dissociar uma coisa da outra.

Pensar em uma marca ou em um produto, portanto, é definitivamente pensar na embalagem, em sua aparência, em seus elementos gráfico-formais. A embalagem, como parte da faceta física da identidade, enquanto interface da marca junto ao público, deve buscar criar um conjunto de características distintas, que se sobressaiam e que não banalizem a marca, valorizando seu significado e contribuindo para gerar conhecimento.

O conhecimento ou Awareness é uma medida que se relaciona à força que a marca tem na memória e que se reflete na capacidade dos consumidores em lembrar da marca como integrante de uma determinada categoria de produtos, de maneira espontânea ou induzida. (AAKER, 1998; KELLER, 2003). Com isso, a marca torna-se familiar, 
passando a ser considerada entre as possíveis opções de compra, mesmo que inicialmente para uma experimentação.

Assim sendo, a partir do momento em que a embalagem é planejada para auxiliar na identificação do fabricante ou marca, na fixação da marca na memória do consumidor e na comunicação da categoria de produtos na qual a marca se insere, a embalagem está colaborando para gerar conhecimento.

Para criar conhecimento de marca através da embalagem é necessário dar ao produto uma identidade obtida por meio da união de recursos gráfico-formais que comuniquem, de forma memorável, exclusiva, favorável e estética: 1) a identidade visual da marca; 2) a categoria de produtos ao qual a marca pertence; 3) a situação de compra, razão de uso e/ou consumo do produto. (KELLER, 2003, p.77).

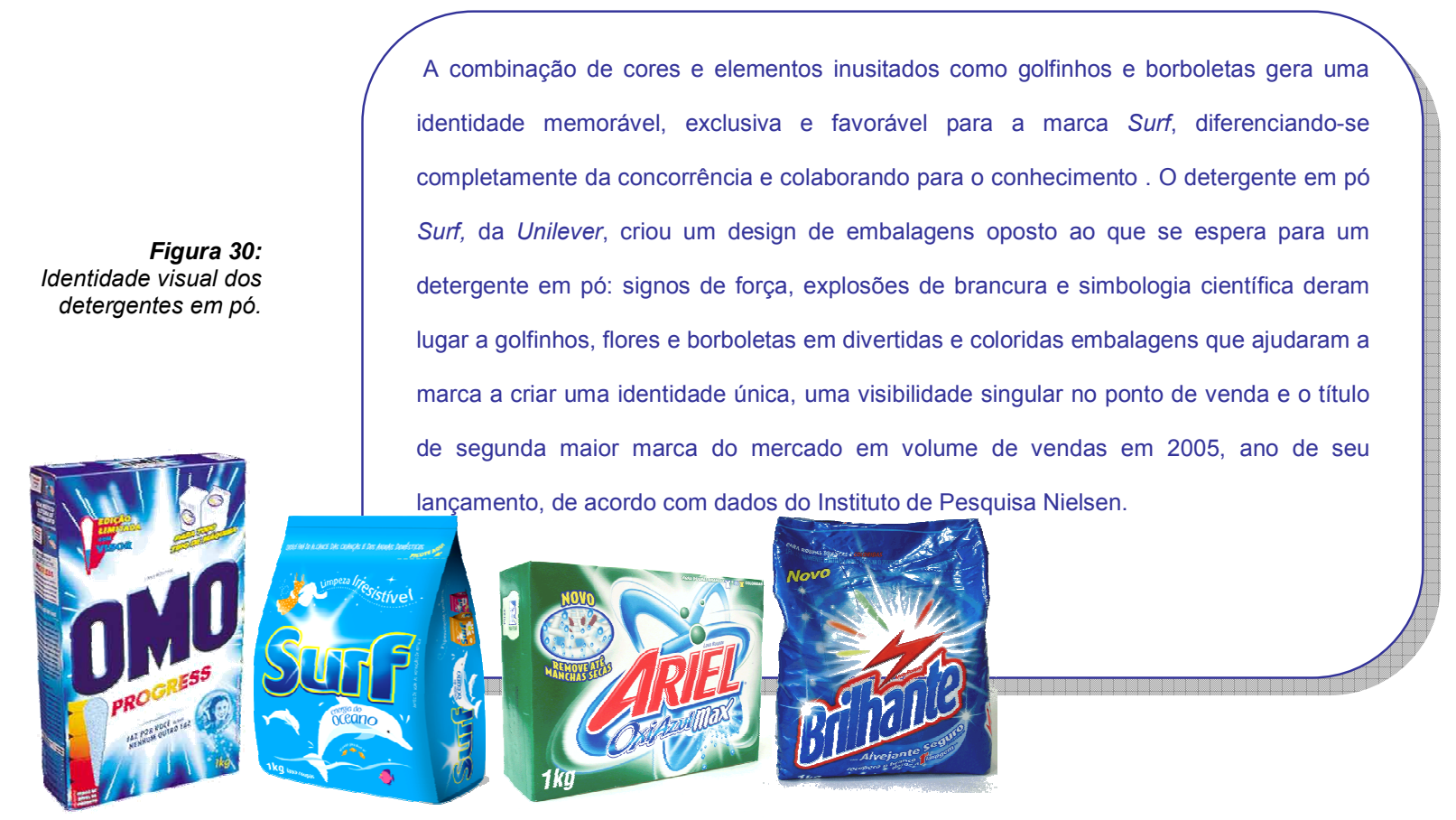

identidade visual da marca refere-se ao aspecto tangível da marca, os componentes essenciais incluindo o nome, a cor, símbolos entre outros elementos gráficos exclusivos da marca. A representação 
visual desses elementos e suas combinações definem a marca e a diferenciam (KLIMCHUK, 2006, p.40). Quanto mais memoráveis, exclusivos, favoráveis e estéticos forem, maior será a capacidade da marca ser identificada, portanto, de gerar conhecimento e lembrança.
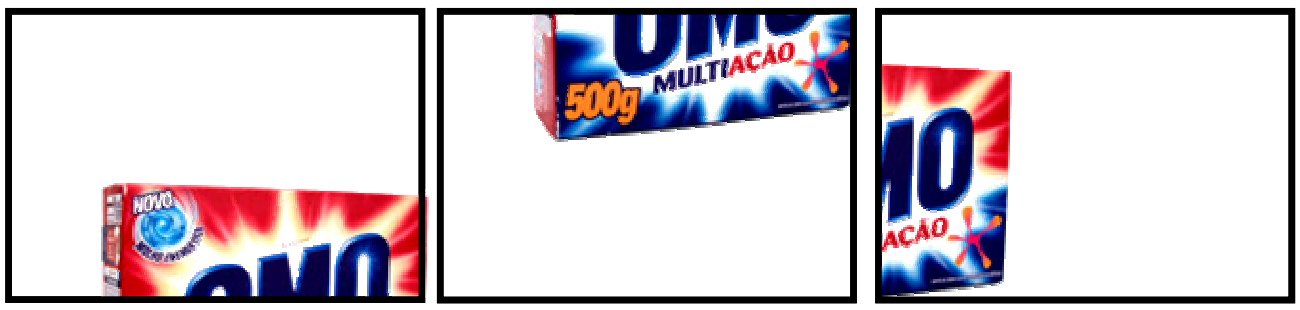

Figura 31: Os

elementos da identidade visual de $O M O$ e de Veja facilitam a identificação e lembrança da marca.
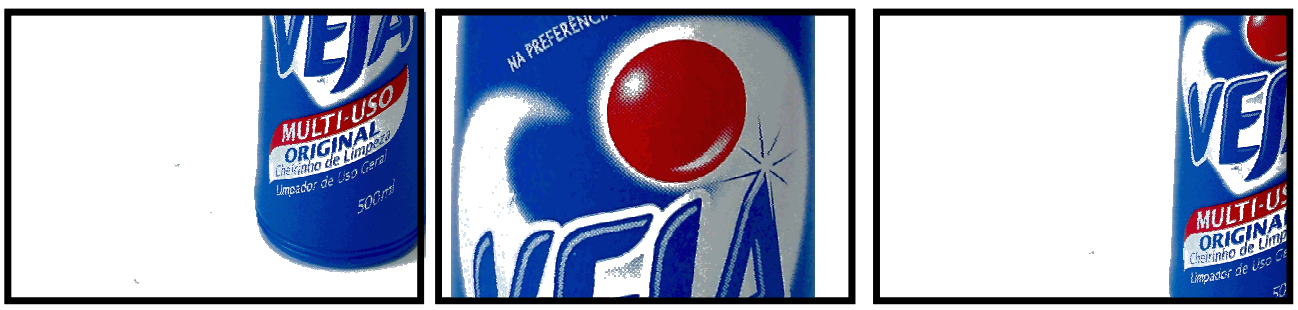

Os elementos indicativos da categoria de produto

constituem pistas importantes ao consumidor. Eles definem a estrutura competitiva de referência; determinam e informam a categoria e segmento nos quais a marca atua e compete, especialmente se ainda não é estabelecida, além de comunicar os atributos, benefícios e imaginário básicos, inerentes da categoria em que a marca atua. É a partir dos elementos indicativos da categoria de produtos que o consumidor vai inferir a qualidade, o desempenho e a conveniência do produto, e como resultado, formar uma imagem sobre a marca e/ou experimentá-la.

De acordo com Mozota (2003, p.84), esse fenômeno ocorre porque os indivíduos estocam mentalmente formas, imagens ou objetos que atuam como referentes ou protótipos e que são utilizados como padrões de comparação entre o novo produto e o conhecimento préexistente dessa categoria, conduzindo à familiaridade e, por conseqüência, à preferência, de modo que, seguir os códigos básicos 
da categoria pode ser um artifício bastante importante no desenvolvimento de uma nova embalagem, especialmente no lançamento de um novo produto.

Os elementos indicativos da categoria são importantes para estimular a experimentação, especialmente para as marcas que têm baixo índice de conhecimento e/ou para extensões de marcas em novos mercados. Criar conhecimento e estimular a experimentação através do design de embalagens pode ser particularmente interessante para as marcas que estão se lançando no mercado, em especial àquelas que não dispõem de significativas verbas publicitárias.

É imprescindível, portanto, que o design da embalagem forneça minimamente as informações que uma marca precisa ter para estar entre as prováveis opções de compra, ou seja, que propicie condições de entrada na categoria em que a marca vai atuar.

Isso não significa que uma nova marca, que precisa construir presença e conhecimento e que opte por diferenciar-se da maioria,

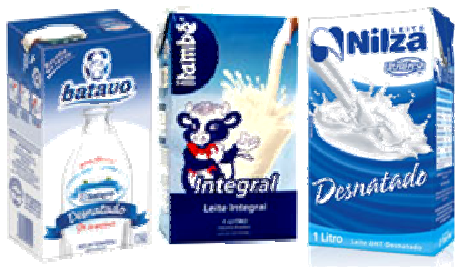

Figura 32: Para algumas categorias de produtos é interessante notar a existência de uma linguagem linear adotada por diversas marcas atuantes na categoria, o que, de alguma forma, "educa" o consumidor na identificação do produto que necessita. Até alguns anos atrás, a primeira imagem de embalagem de leite que vinha à mente das pessoas era o "saquinho de leite". Com a migração do mercado para as embalagens tetra-pack, pensar em leite hoje é pensar em uma caixinha, normalmente branca, azu ou verde, cores leves, design limpo e simples. A maior parte das marcas deste segmento de produtos apresenta-se dessa forma no ponto de venda, indicando a

categoria a que pertencem. $\mathrm{O}$ consumidor aprendeu quais são os códigos visuais que a categoria de

leite se utiliza, e algo totalmente diferente poderia implicar em risco: É leite? É Puro? Pasteurizado? Tem qualidade? É confiável? escolhendo uma estratégia de quebra de linguagem de categoria para chamar a atenção, esteja fadada ao fracasso.

Avaliando a embalagem do sabão em pó Surf, dono de design gráfico relativamente inusitado em relação às opções disponíveis do mercado e, comparando-o contra as marcas mais estabelecidas, encontraremos os principais e, provavelmente, mais importantes códigos ou indicativos de categoria presentes no design de sua embalagem.

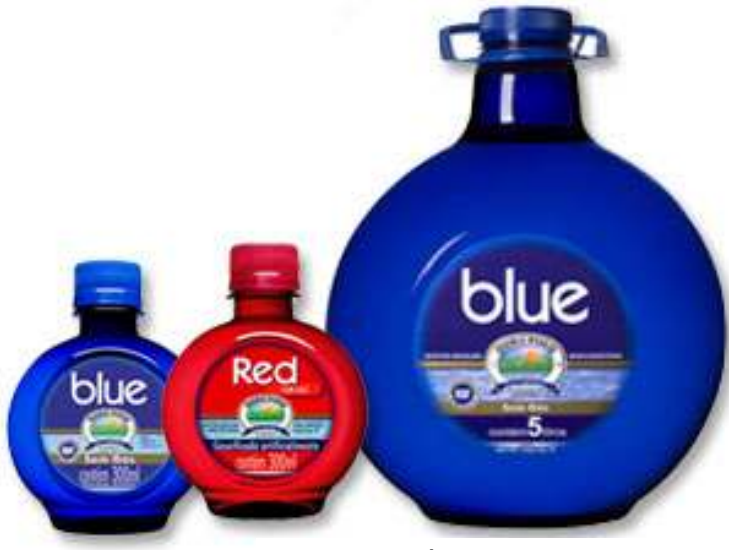

Figura 33: Águas Ouro Fino Red e Blue: Diferenciação de produto através de embalagens mais sofisticadas que podem ir à 


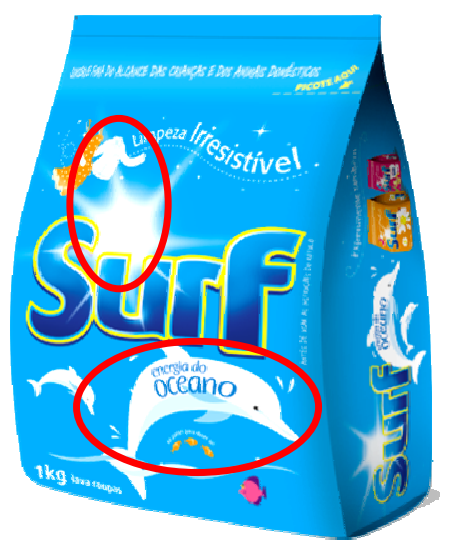

Códigos de brancura: grande parte das embalagens de detergente em pó reservam uma área branca significativamente grande no painel frontal da embalagem, solução gráfica que remonta às primeiras embalagens de

detergente em pó lançadas no mercado. O uso da cor branca pode gerar associações de limpeza, pureza, de higiene, associações extremamente relevantes para um sabão em pó. "O branco" também é a prova mais dura pela qual a dona de casa e o próprio produto têm de passar - as roupas brancas não mentem, denotam a sujeira, o encardido, o amarelado, as manchas e, conseqüentemente, a qualidade do produto e a capacidade da dona de casa em deixá-las limpas.

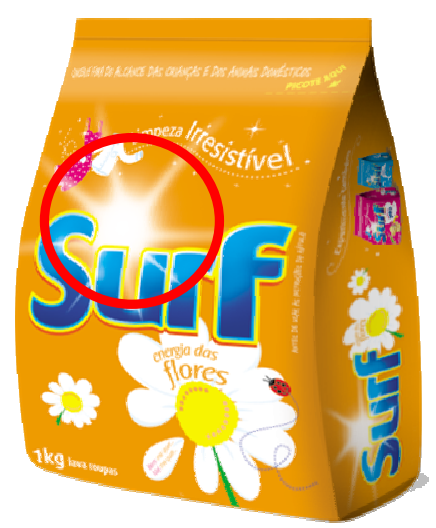

Códigos de eficiência: muitas
embalagens se utilizam de um
efeito luminoso, na cor branca,
similar ao brilho de uma estrela ou
de uma explosão. O uso desse
elemento pode estar associado à
intenção de demonstrar força, a
capacidade do produto em deixar a roupa branca e limpa, já que a "explosão" remete à intensidade, poder e energia. Toda essa energia e força eram empregadas, antes do advento do detergente em pó, pelas donas-de-casa ao utilizarem pedras de sabão para lavar as roupas - era necessário esfregar muito para remover as sujeiras mais difíceis e deixar as roupas da família brancas e impecáveis. Uma família limpa e bem vestida retrata a capacidade da 
mulher em gerir os deveres domésticos ${ }^{13}$ e cuidar da família - uma mulher exitosa nesse aspecto, torna-se a rainha do lar, que "brilha" ao deixar toda a família "brilhando", tanto quanto a estrela ilustrada na embalagem

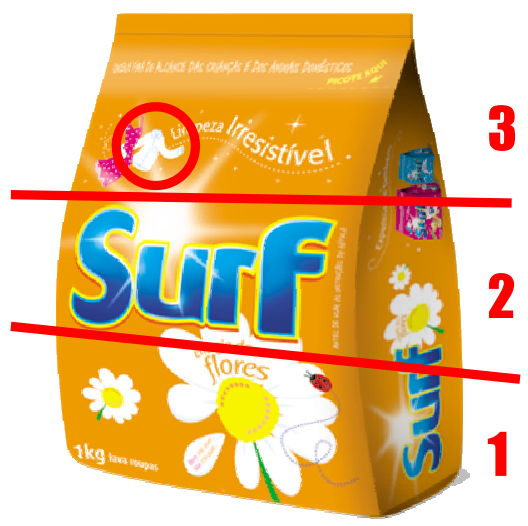

Códigos de limpeza: Uso da cor azul no logo de Surf, abundantemente utilizada na categoria, tomando a porção central da embalagem e aproximadamente $1 / 3$ do painel frontal, pode ser associado à própria água, essencial na limpeza e na lavagem da roupa, como também ao anil, produto largamente empregado no passado para alvejar as roupas. O uso da imagem da camisa branca, extremamente explorada nos comerciais de produtos da categoria, também colabora para a construção de associações de limpeza, brancura e eficiência do produto; a camisa branca e bem passada é o resultado esperado pelo usuário.

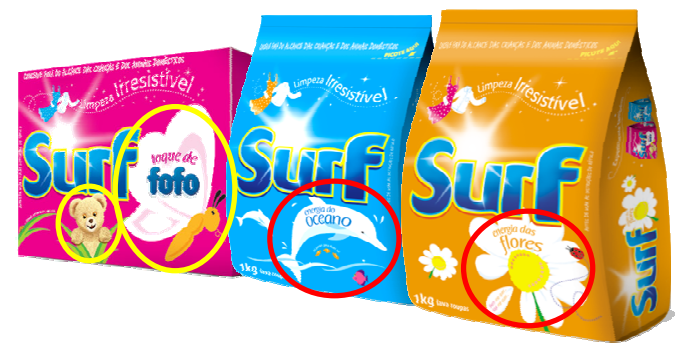

Códigos de cuidado: ao cuidar da roupa, a mãe, esposa ou donade-casa demonstram todo o carinho com a família. Os elementos gráficos como a borboleta, a flor, o golfinho e o urso de pelúcia denotam delicadeza, leveza, sensibilidade e beleza,

\footnotetext{
${ }^{13}$ Segundo pesquisas realizadas pela autora durante o tempo em que trabalhou na categoria, usuárias revelam que uma família com roupa bem cuidada é sinônimo de uma mãe ou esposa exemplar.
} 
atributos estreitamente ligados ao universo feminino, criando não só uma maior identificação entre usuário e produto, como também denotando o caráter cuidadoso, sensível e zeloso da mulher. Além disso, a partir dos elementos utilizados, é possível atribuir ao produto, qualidades funcionais de cuidado com a roupa e com a pele das mãos, sugerindo um risco menor de alergias ou irritações dermatológicas.

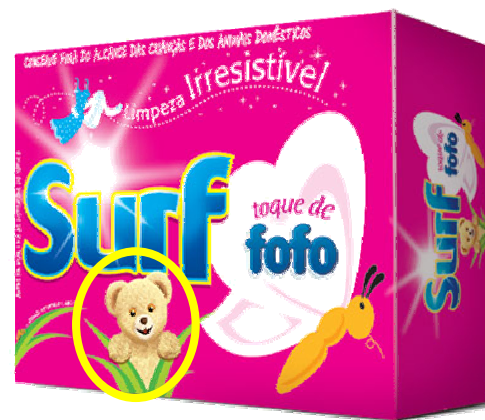

Códigos de Maciez: Maciez é um resultado esperado pelos usuários de detergente em pó e o urso de pelúcia reforça esse benefício visto que configura um símbolo extremamente utilizado no universo comunicativo da categoria de amaciantes e no universo infantil.

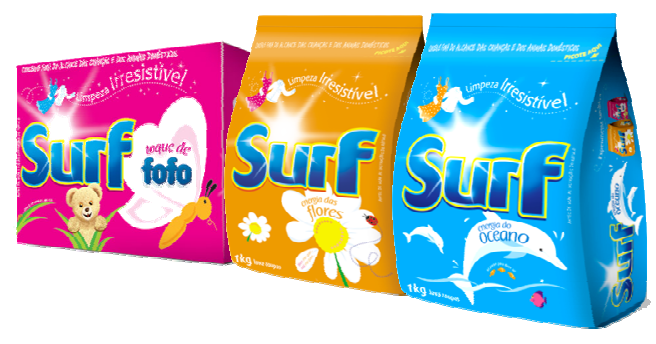

\author{
Códigos de Perfume: \\ roupas limpas, macias \\ e cheirosas, são os \\ principais benefícios \\ esperados pelos
} consumidores de detergente em pó. O uso de elementos como as flores, a borboletas e o mar, associado ao uso das cores de fundo, laranja, rosa e azul, respectivamente, podem gerar associações que reforcem a qualidade e a intensidade do perfume do produto. O perfume de um campo florido e ensolarado, o perfume de uma tarde primaveril ou o aroma fresco do mar são associações que contribuem para reforçar a percepção do atributo "qualidade de fragrância e perfumação" do produto.

O elementos indicativos de situação de compra, razão de 
uso e/ou consumo do produto comunicam o posicionamento da marca e também ajudam a criar conhecimento. Através dos elementos gráficos da embalagem é possível comunicar para quem o produto se destina, para qual ocasião de uso e, por fim, qual o benefício que justifica a compra e uso do produto.

No caso de Surf, os elementos flor, golfinho e borboleta, ao mesmo tempo em que ajudam a identificar a linha de produtos e seus benefícios, são, do ponto de vista simbólico, imagens profundamente relacionadas ao universo feminino, que certamente ajudam a criar uma identificação emocional das mulheres com o produto: O golfinho, um animal meigo, dócil, inteligente, também associado à fertilidade; a flor, símbolo do feminino, do romantismo e da fragilidade e a borboleta, remetendo à leveza, delicadeza e à primavera, estação da vida. .

Assim, do ponto de vista de construção do conhecimento de marca, ao pensar no design de uma embalagem é importante:

- Definir e priorizar os benefícios que serão comunicados ao consumidor via embalagem, comunicá-los de maneira atraente, gerando desejo, bem como comunicar os atributos que viabilizam e tornam a promessa crível e capaz de ser desempenhada pela marca;

- Fornecer os códigos ou indicativos da categoria de produtos em que a marca atua: quais são os códigos dessa categoria de produtos? Como a concorrência explora o design de embalagem, especialmente as marcas líderes de mercado? Quais informações são valorizadas pelo consumidor, devendo ser comunicadas? Quais os indicativos de qualidade que devem estar presentes no design da embalagem;

- Fornecer indicativos de compra, uso e/ou consumo do produto: quais são os benefícios mais importantes que justificariam a compra e como eles se apresentam? Quais as razões ou 
atributos do produto que dão credibilidade a esses benefícios?

Elas estão presentes no design da embalagem? Existem especificidades de uso e consumo que devam ser comunicadas? Está clara a utilidade do produto, especialmente em categorias muito segmentadas?

- Elementos de identificação de marca: quais os elementos de design que materializarão a identidade da marca? Estão alinhados a sua personalidade, valores e missão? São suficientemente memoráveis, exclusivos e favoráveis? Como se diferenciam da concorrência? Geram visibilidade e impacto no ponto de venda? São geradores de associações positivas para a marca?
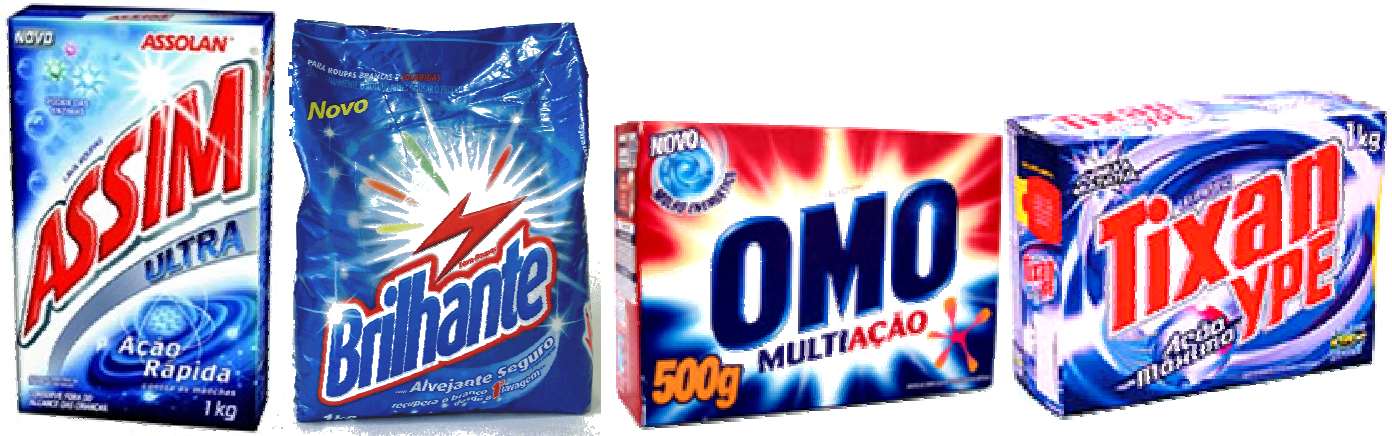

Já a marca Assim, da Assolan, optou por uma estratégia de design de embalagem que priorizou a manutenção da linguagem da categoria, utilizando elementos e estratégias de comunicação similares às demais marcas, que resultaram em um design extremamente funcional, oposto à estratégia emocional de Surf: Avaliando sua sintaxe visual (DONDIS, 2003), é possível verificar:

- $\quad$ Cor: predominância da cores branco e vermelho e dos tons variados de azul, o que implica em um uso mais racionalizado e menos emocional da cor - a variação tonal define a complexidade da mensagem visual, promovendo
Figura 35: Assim manteve a estratégia visual da categoria: predominância das cores azul, branco e vermelho, forma retangular, presença de figuras como raios e estrelas e logomarca posicionada na diagonal. 
uma maior riqueza de informações. Do ponto de vista semântico, as cores azul e branco resultam em códigos de limpeza e brancura, remetendo à água, à roupas aniladas; o vermelho representando força, ação, energia, características imprescindíveis a um detergente no combate à sujeira, reforça o código de eficiência;

- Forma: predominantemente retilínea, com destaque para retângulos e triângulos, que costumam ser associados à ação, honestidade e esforço. Do ponto de vista figurativo, raios e estrelas também configuram os códigos de eficácia, indicando força, poder de limpeza, ação e energia. O brilho, presente em todas as embalagens, demonstra $\mathrm{o}$ resultado: roupas brilhando; brilho que também pode ser associado a sucesso. Representações de átomos, moléculas e partículas reforçam os apelos científico, tecnológico e de inovação,
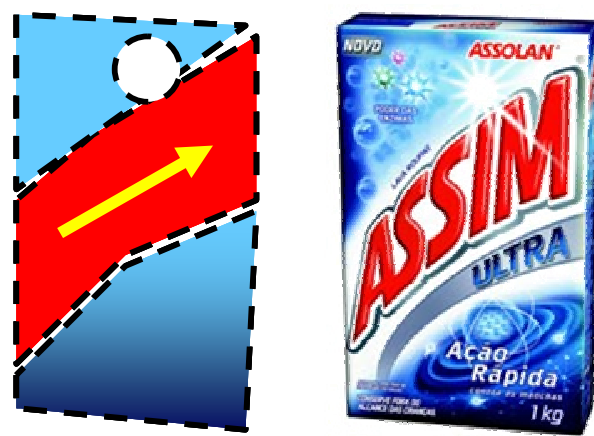

(a)

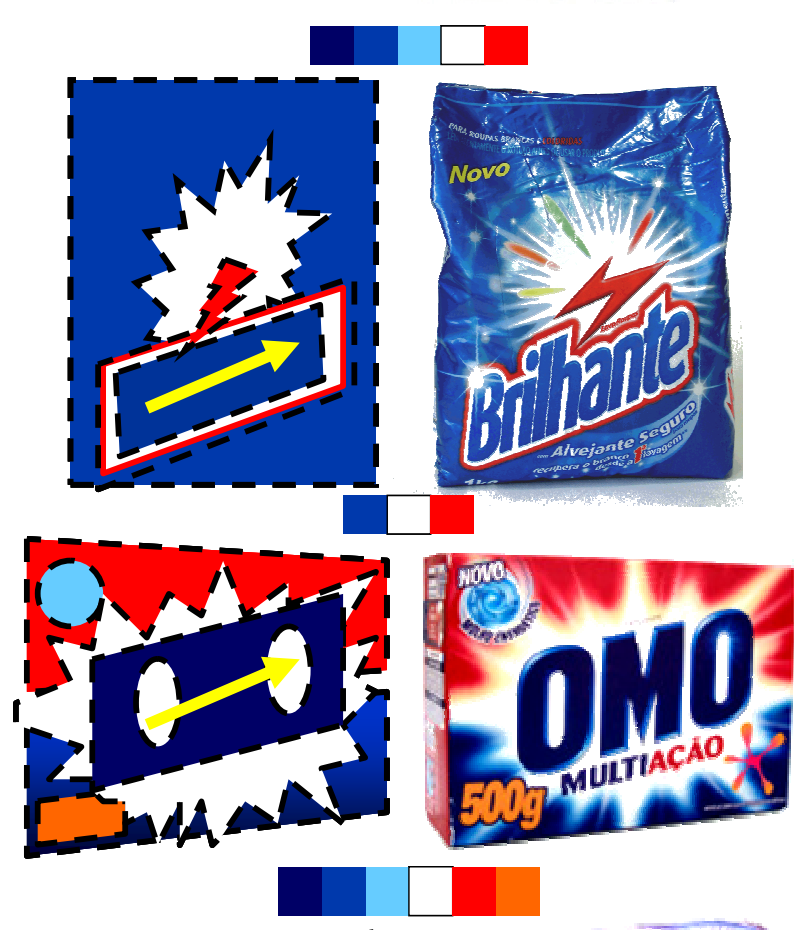
logos os atributos funcionais. Já a

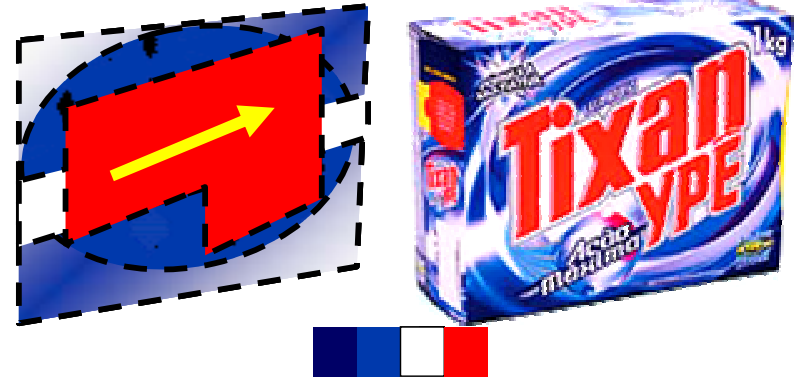

Figura 36: Análise da sintaxe visual das embalagens de sabão em pó Assim, Brilhante, espiral, elemento integrante do OMO e Tixan.

processo de lavagem, denotando ação, continuidade e

força, como o redemoinho de água, natural ou da máquina

de lavar, que limpa e leva embora a sujeira;

- Direção: uso de diagonais ascendentes, contrastes 
promovendo instabilidade e ação;

- Estratégias visuais determinam um design funcional: os elementos visuais estão dispostos de modo a criar instabilidade; a formulação é simples e econômica, criando unidade visual em torno do logotipo, o que proporciona impacto; além disso, o design sugere atividade, propiciado pelo uso de forças diagonais e formas triangulares; elementos justapostos ativam a comparação das relações entre ambos e o uso de contornos rígidos e precisos resulta em clareza visual.

Todos esses elementos foram arranjados de forma a garantir fortes contrastes de cor e de forma, o que garante uma boa visibilidade às marcas individualmente, mas que, ao serem colocadas lado a lado no ponto de venda, passam a criar uma "massa visual" homogênea, impossibilitando um destaque individual.

Embora os indicativos de categoria e de uso do produto sejam evidentes, o design da embalagem não denota elementos exclusivos e memoráveis, perdendo destaque em relação os demais produtos concorrentes, principalmente aqueles que estão estabelecidos a mais tempo no mercado, possibilitando, até mesmo, uma percepção de plágio.

É importante, portanto, determinar qual a estratégia de design a ser adotada: seguir ou quebrar a linguagem estabelecida pelo mercado. Essa é uma decisão difícil, devendo variar em função dos riscos atrelados e de uma série de outros fatores como a cultura da empresa, as características da categoria de produtos em questão, a representatividade das marcas líderes nessa categoria, o plano estratégico da marca, os objetivos de negócio, o posicionamento e a identidade pretendidos para a marca, o orçamento assim como o plano de comunicação da marca, etc. 


\section{3 - Embalagens para comunicar o posicionamento da marca}

O posicionamento é um conceito que busca "apresentar o produto ao mercado revestido das condições mais favoráveis para conquistar a preferência do consumidor" (MITSURO, 2007, p.67).

Criar um posicionamento significa identificar uma localização ótima para a marca e para seus concorrentes na mente dos consumidores, de modo a maximizar benefícios para a empresa. $\mathrm{O}$ conceito de posicionamento é um conceito crítico porque estrutura as associações de marca criando significado para ela.

No que tange ao design de embalagens, o posicionamento determina quais são as informações importantes a serem comunicadas, informações estas que deverão distinguir a marca da concorrência, fornecer uma razão única de compra para o consumidor e contribuir para a construção de associações positivas para a marca.

Para diversos autores, entre os quais Mozota (2003 ), Kapferer (2003) e Kotler (2000), o posicionamento trata de evidenciar as características distintivas da marca em relação à concorrência e motivadoras para o público, respondendo as seguintes perguntas: para quem (publico alvo), por quê/para quê (promessa - atributos e benefícios), para quando (quais situações de uso), contra quem (contexto competitivo).

A promessa do produto se relaciona ao conjunto de atributos e benefícios ofertados pela marca.

Atributos são propriedades que o produto detêm, que justificam e qualificam a sua capacidade de desempenho na função a que se destina, diferenciando-o da concorrência e gerando associações para a marca que podem se traduzir em razões de compra (KELLER, 2003; KAPFERER, 2003; AAKER, 1998).

Segundo Mitsuro (2007, p.66), o conhecimento efetivo dos 
atributos possibilita à marca maximizá-los, incrementando a percepção de seus clientes em relação à oferta. Esses atributos podem ser tangíveis e intangíveis, sendo que o produto ideal sempre carrega uma equação bem equilibrada de ambos. "Ainda conforme o autor, é a somatória dos atributos tangíveis e intangíveis de um produto que o faz único, diferente".

A maioria dos atributos do produto proporciona benefícios aos consumidores e, por isso, atributos e benefícios estão interrelacionados. Os benefícios são "o significado e o valor pessoal que os consumidores destinam aos atributos do produto" (KELLER, 2003, p. 71). Podem ser distinguidos em racionais e psicológicos ou emocionais.

Os racionais são estreitamente vinculados ao produto em si, sendo comunicados através de um argumento lógico ao consumidor. São aqueles que podem ser justificados e aceitos mais facilmente oferecendo, porém, maior probabilidade de serem copiados. "Propiciam condições de entrada (....). São qualidades implícitas que uma marca precisa ter para estar entre as prováveis opções de compra" (ELWOOD, 2004, p.156).

Já os emocionais relacionam-se aos sentimentos despertados durante a compra, uso ou consumo do produto, gerando um desejo impulsivo que é, posteriormente, racionalizado pelo consumidor através do benefício racional. De modo geral, benefícios racionais e emocionais caminham juntos para maximizar associações exclusivas de marca e oferecer mecanismos de defesa contra a concorrência (AAKER, 1998; ELWOOD, 2004).

A embalagem desempenha um importante papel na comunicação da promessa de um produto, visto que o consumidor constrói suas expectativas a respeito do desempenho da marca, baseado nas percepções que adquiriu através das ações de comunicação, mas especialmente da embalagem, já que $85 \%$ das 
compras em lojas de auto-serviço são feitas sem prévio planejamento (BLESSA, 2005, p.25).

A embalagem contribui para construção de significado da marca a partir do momento em que é capaz de comunicar o posicionamento ao consumidor, despertando interesse, gerando identificação e mobilizando-o para a compra. À medida que o Design da embalagem é capaz de "contar uma história" ao consumidor, ou seja, de comunicar o conceito do produto, ele está contribuindo para posicionar a marca na mente do consumidor e desempenhando, efetivamente, a sua função de vendedor silencioso. Como exemplo, procederemos à seguinte análise:

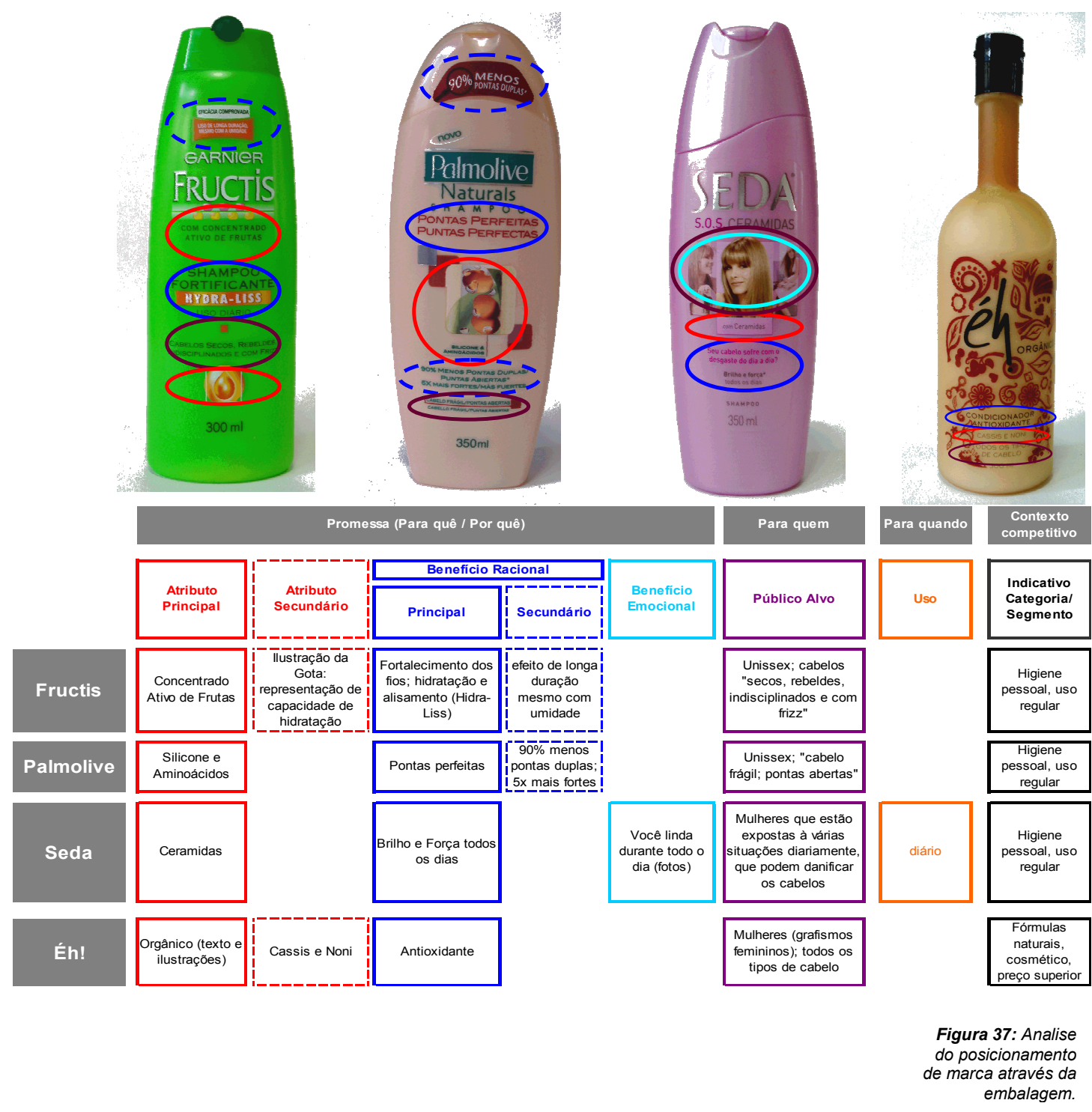


Portanto, nas embalagens de xampu das marcas Seda, Fructis e Palmolive, é possível ver claramente a posicionamento expresso no design das embalagens, seja a partir de elementos-texto ou elementosfigura. Cada uma das marcas expressa sua promessa de maneira diferente:

- Fructis: quase não se utiliza figuras a não ser pela representação de uma gota, normalmente usada para significar hidratação. As demais informações são comunicadas a partir de texto, resultando em um design pouco visual, extremamente racional, que demanda do consumidor um tempo para leitura e entendimento da promessa do produto, especialmente pela quantidade de dados disponibilizados. Não determina claramente o público almejado a não ser pela declaração da necessidade a ser atendida: pessoas com cabelos secos, rebeldes, indisciplinados e com frizz;

- Palmolive: também se caracteriza por um design baseado fortemente em textos informativos, com a diferença que ilustra o atributo que suporta o benefício, conferindo-lhe ênfase e destaque ao posicioná-lo na porção central da embalagem - silicone e aminoácidos. A figura funciona como um elemento de atração e também materializa o atributo de difícil compreensão;

- Seda: Apresenta um design mais limpo, focado nas informações fundamentais, hora representadas por texto, hora por imagens. É o único que representa, ao mesmo tempo, a promessa e o público a partir de uma foto, buscando uma proximidade e identificação junto ao consumidor - no caso, mulheres. A foto, que ilustra vários momentos do dia da consumidora, também expressa o

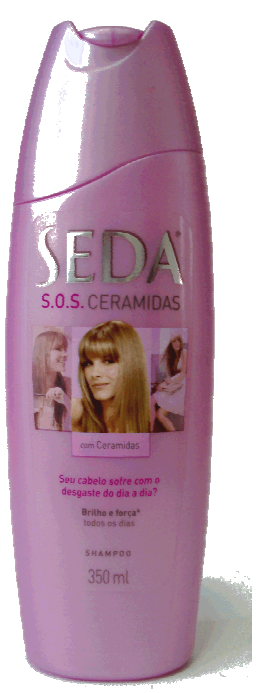


benefício emocional, não comunicado pelas demais marcas:

a representação de uma mulher linda e confiante, durante os vários momentos e atividades do dia;

- Éh!: o design praticamente dispensa elementos-texto, fazendo uso intenso de imagens como flores, plantas, folhas, que se conectam ao universo feminino, ao universo da beleza e da natureza, reforçando o benefício do produto: xampu orgânico, antioxidante. $\mathrm{O}$ formato do frasco extremamente diferenciado da categoria, remetendo à linguagem da perfumaria e cosmética fina busca reforçar um posicionamento cosmético, superior ao contexto de higiene e beleza em que as demais marcas atuam, sugerindo também um preço superior.

Compreender o significado e a importância de cada uma dessas informações é fundamental na determinação da organização dos elementos visuais na embalagem, ou seja, na constituição de uma hierarquia comunicativa.

A hierarquia comunicativa na embalagem é responsável por refletir o conceito do produto. No marketing direto ou mesmo nas campanhas publicitárias, é possível contar para o consumidor, através de uma linha de argumentação - persuasão, as vantagens em adquirir determinada oferta. A embalagem, ou o "vendedor silencioso", deve dispor de artifícios para também desempenhar essa função. A hierarquia comunicativa estabelece um roteiro de leitura, de argumentação e de persuasão, ajudando a contar a história, o conceito daquela oferta, começando pelas informações mais imprescindíveis e terminando nas mais básicas. 


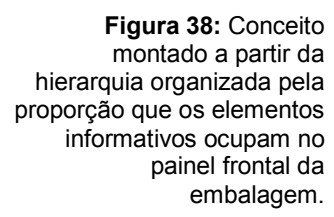

1) Para você que vive intensamente o seu dia e que quer estar com os cabelos cuidados e bonitos sempre, 2) Seda traz um novo produto: 3) SOS Ceramidas, que cuida do 4) desgaste sofrido diariamente pelos fios, 5) conferindo brilho e força através das 6) ceramidas.

Os elementos primários da hierarquia compreendem os traços de identificação da marca e a comunicação do posicionamento do produto. Já os elementos secundários compreendem a comunicação de informações técnicas, como ingredientes, modo de uso, recomendações, cuidados e restrições, código de barras, e a comunicação de informações legais como conteúdo, dados sobre o fabricante, validade do produto, contato para serviço de atendimento ao consumidor e informações regulatórias.

Seja qual for o tipo de estrutura física ou o material da embalagem - papel, vidro, alumínio, plástico, sempre haverá uma área destinada para a comunicação das informações mais importantes, ou seja, os elementos primários, e uma área reservada para a comunicação dos elementos secundários. A primeira é comumente conhecida por painel principal da embalagem, ou ainda, painel frontal ou rótulo e a segunda, painel secundário, traseiro ou contra-rótulo.

A escala, a cor, a posição, os contrastes, a proporção entre os elementos, etc, constituem algumas formas de priorizar informações, tanto no painel principal quanto no traseiro, estabelecendo a hierarquia comunicativa no design de embalagens. A hierarquia será bem sucedida se for capaz de conduzir o receptor por uma seqüência de leitura lógica, 
da informação mais importante para a menos importante, despertando a curiosidade do consumidor, propiciando o pleno entendimento das informações e, por fim, propiciar envolvimento com o produto, o que pode resultar na compra.

Segundo Klimchuck (2006, p.82), as cores, a estrutura física, os símbolos, números e a tipografia são os elementos visuais que normalmente funcionam como pontos de atração no design de embalagens, sendo capazes de

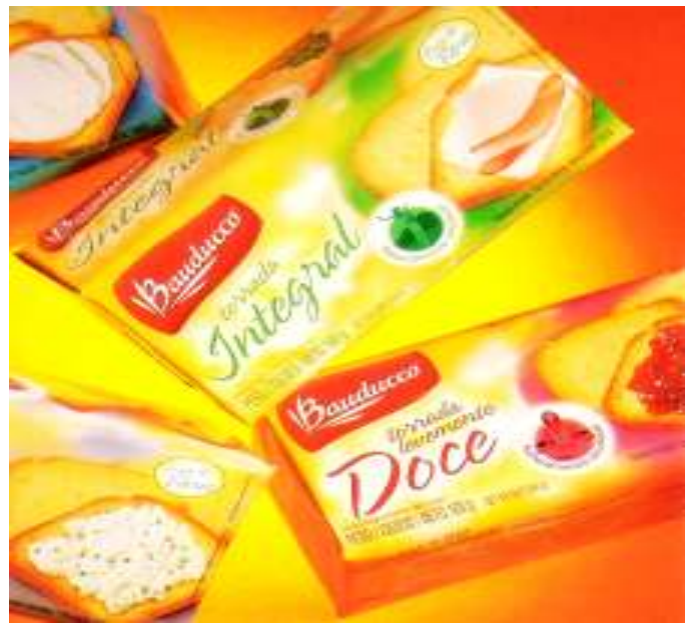
instigar, provocar e gerar curiosidade.

Avaliando-se as embalagens disponíveis hoje no mercado, verifica-se um maior uso desses elementos em quase todas as categorias, o que, de certo modo, acaba constituindo uma receita importante de quais elementos devem ser escolhidos para a composição de uma hierarquia funcional.

Entretanto, a combinação desses elementos na embalagem deve, além de criar uma lógica de leitura, proporcionar uma solução clara, verbal e visualmente, além de apropriada culturalmente, ou seja, alinhada ao perfil do grupo de compradores alvo, criando identificação e uma solução diferenciadora e impactante, de modo a constituir um design efetivo.

Para tanto, é imprescindível atentar aos seguintes aspectos:

- Clareza quanto aos objetivos de marketing e o desenvolvimento de soluções voltadas para esse objetivo: a solução de design pode ser completamente distinta dependendo dos objetivos de marketing previamente estabelecidos, e tanto será mais efetiva quanto responder a esses objetivos. Ampliação de linha, extensão de marca em nova categoria de produtos, novo posicionamento, fortalecimento de imagem, rejuvenescimento de imagem,

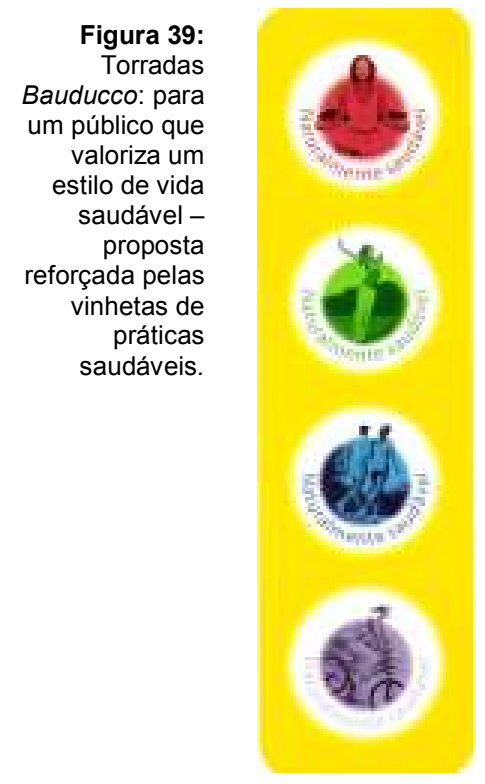


ação tática contra a concorrência - o design da embalagem

deve endereçar os objetivos de marketing;

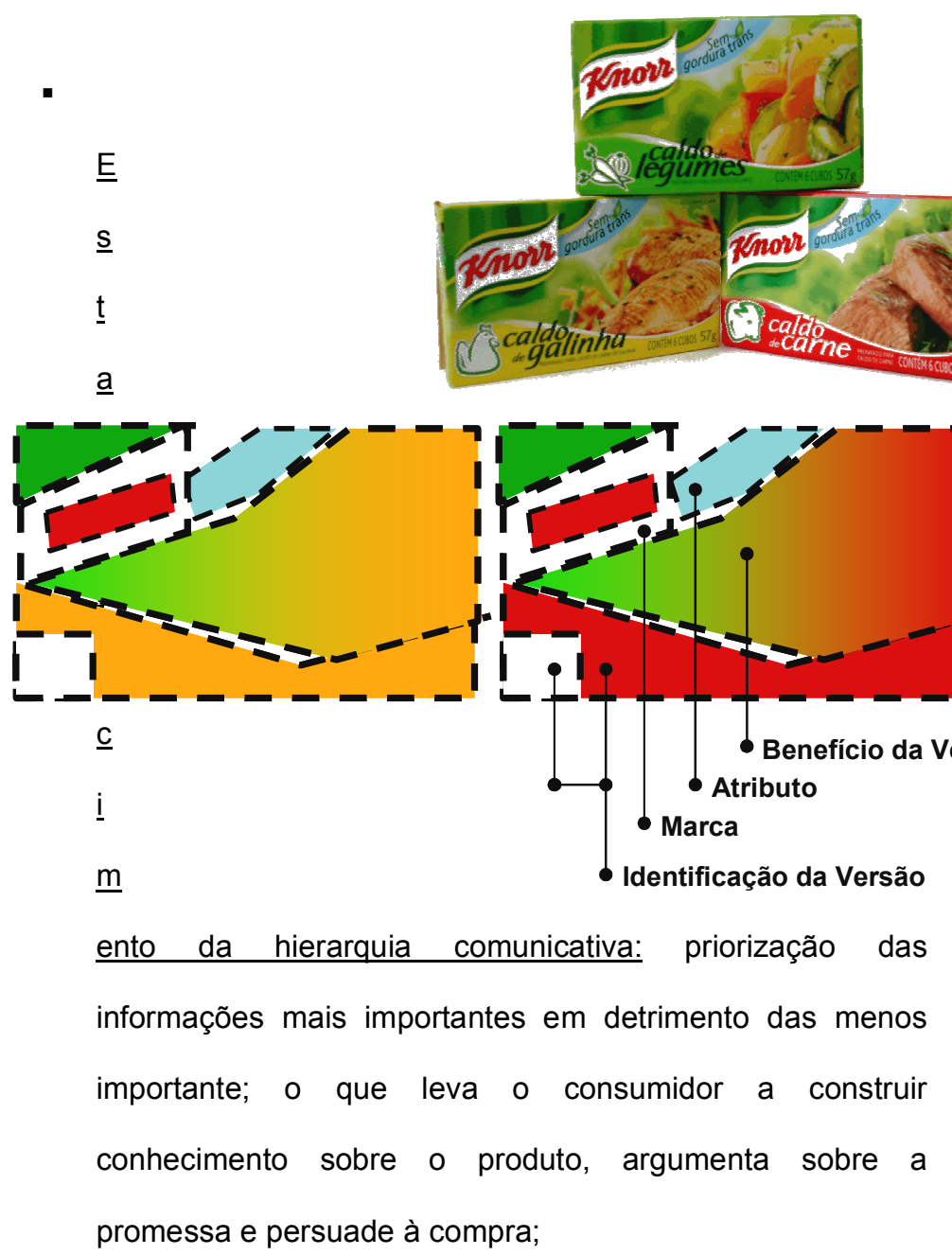

- Definição da linguagem estética do grupo: traduzir todo o conhecimento do publico alvo, sua cultura, hábitos, atitudes em um design que crie identificação;

- $\quad$ Alinhamento à personalidade da marca;

- Sintetização das informações em símbolos fortes: extrair as informações mais importantes do brief de design de embalagens e sintetizá-las em símbolos que proporcionem entendimento, impacto e que enalteçam o posicionamento do produto, sua promessa, seus atributos, seu público, etc;
Figura 40: $O$ design da linha Knorr de caldos dá unidade à linha de produtos, propiciando fácil identificação das versões. 
- Uso dos princípios básicos do design: o alfabetismo visual, a Gestalt, a semiótica, a ergonomia.

Assim, o design da embalagem pode desempenhar o importante papel de traduzir os valores da marca em características ou atributos de produto, estabelecendo o significado da marca na mente dos consumidores. O Design torna-se o ponto de equilíbrio entre os aspectos funcionais e emocionais da marca, melhorando sua coerência global, sua imagem e até mesmo sua percepção de desempenho, o que se reverte em um conjunto de associações positivas, tangíveis e intangíveis para a marca.

No xampu Seda Anti Sponge, alguns elementos colaboram na

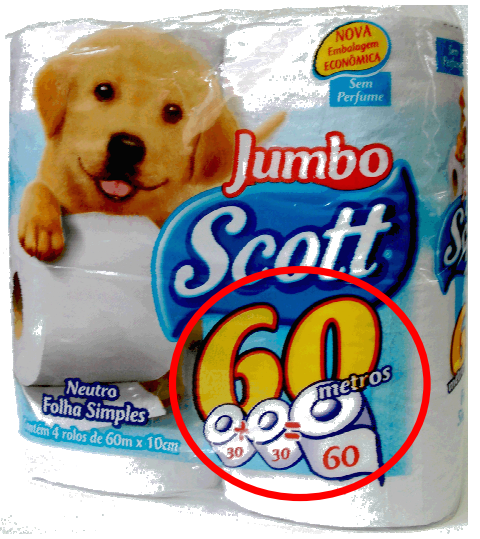

Figura 42: A embalagem do papel higiênico Scott soube enaltecer o posicionamento econômico da marca, sintetizando a informação em um símbolo forte e claro: cada rolo com o dobro de metragem que os normais no mercado. definição do posicionamento da marca:

- Benefícios do Produto: na versão Anti Sponge, o benefício é comunicado verbalmente através do texto "hidratação e controle" e reforçado visualmente pela foto que denota um cabelo brilhante, hidratado e controlado. É através da foto também que a consumidora reconhece a promessa do produto, sendo possível identificar tanto o resultado funcional refletido no cabelo, quanto o emocional refletido na postura da personagem que ilustra a foto: no caso de Anti Sponge, cabelos lindos, com volume controlado e uma postura auto-confiante, quase poderosa da personagem;

- $\quad$ Atributos do produto: a tecnologia anti-

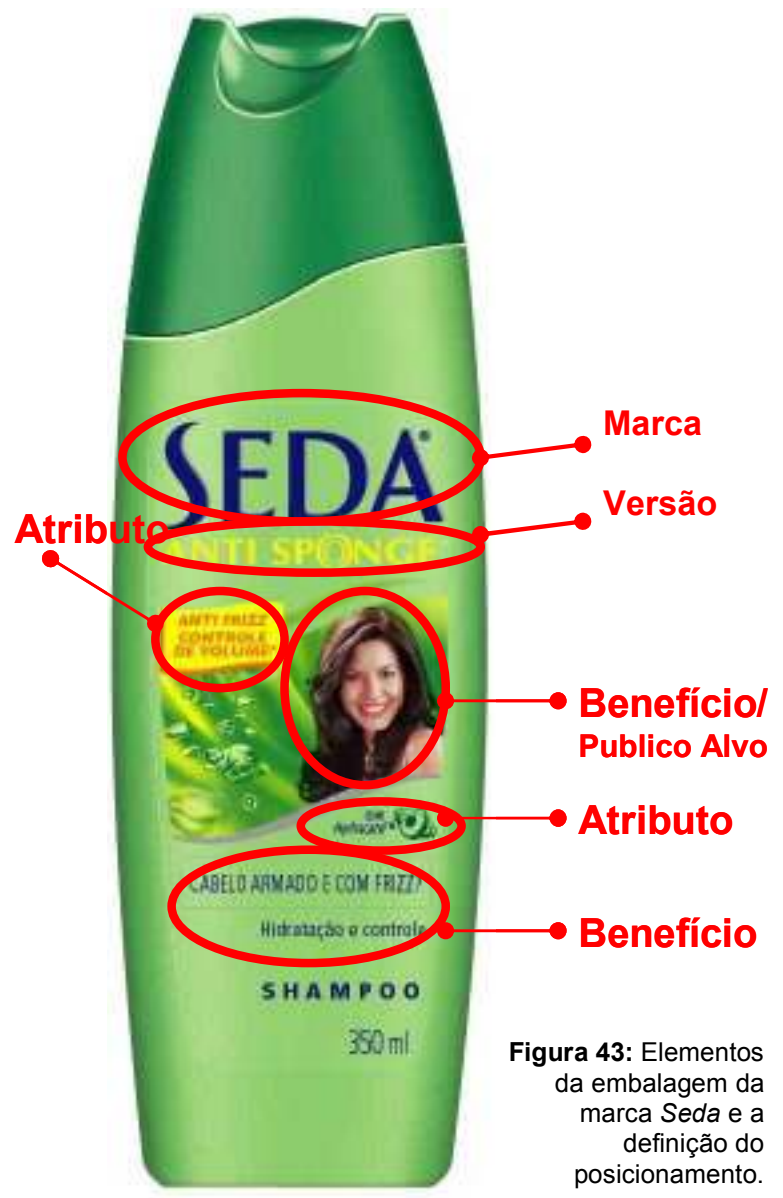
frizz de controle de volume, expressa verbalmente na arte 
da embalagem, e o ingrediente ativo Hidracate, constituem uma razão para o consumidor acreditar na eficácia do produto: os cabelos armados e com frizz vão ficar hidratados e sob controle porque Seda possui tecnologia anti-frizz de controle de volume e Hidracate, que hidrata os fios;

- Público alvo: A foto constitui um elemento que cria identificação com a consumidora: a consumidora pode se reconhecer no próprio produto e entender que Seda endereça todas as necessidades inerentes ao seu tipo de cabelo;

- Além disso, a foto da mulher com cabelos lindos pode ser um elemento de design que propicie condições de entrada na categoria para novas marcas, ainda não estabelecidas, gerando maior confiança no produto. Outro elemento bastante utilizado nas embalagens de xampu e que pode funcionar como indicativo de categoria são as ilustrações que demonstram a ação do produto nos fios, embora seja uma informação visual normalmente presente no contrarótulo das embalagens.

É importante, portanto, avaliar como o design pode ajudar a marca a ganhar relevância por meio da comunicação exclusiva e clara do posicionamento do produto e quais associações adicionais podem ser criadas nesse processo. Para tanto, são relevantes as seguintes considerações:

- O design da embalagem comunica a promessa do produto, ou seja, os benefícios racionais e emocionais da oferta, criando razões ou justificativas para a compra?

- O design da embalagem comunica os atributos tangíveis e
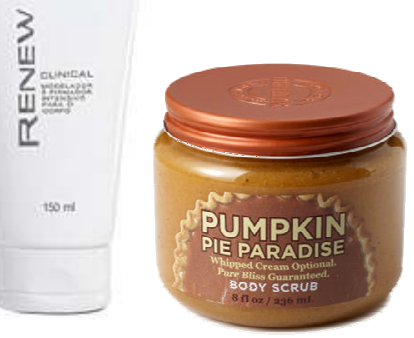

Figura 44: Renew da Avon design medicinal inspira embalagem de creme para o corpo aludindo a propriedades técnicas do produto. Em contrapartida, o creme para o corpo Pumpkin reforça a natureza sensorial do produto e o prazer durante o uso a partir de uma embalagem que remete á produtos comestíveis. intangíveis do produto? 
- O design comunica as situações de uso para o produto?

- O design comunica para qual público se destina, gerando identificação?

- O design comunica o segmento competitivo: econômico, qualidade inferior, qualidade superior, caro, etc...

- A solução de design da embalagem está alinhada ao benefício central do produto? Uma linguagem racional para um benefício utilitário; uma linguagem sensorial para benefícios emocionais.

As marcas também podem ser posicionadas de acordo com a percepção de qualidade e de valor, ou seja, sua relação custo-benefício. A embalagem tem grande influência na formação dessas percepções como tratado a seguir.

\section{4 - Embalagens para reforçar a percepção de qualidade da marca}

"Qualidade é a totalidade dos atributos e características de um produto ou serviço que afetam a capacidade do consumidor de satisfazer as necessidades declaradas ou implícitas" (KOTLER, 2000, p.79).

No âmbito do Branding, a qualidade percebida difere da qualidade real do produto, da qualidade de fabricação, para dar lugar a uma dimensão cognitiva da qualidade, em que estão envolvidos julgamentos pessoais baseados naquilo que é mais valorizado por cada indivíduo. A qualidade e a percepção de qualidade são importantíssimas no gerenciando de marca, visto que, para se construir uma marca poderosa, é imprescindível construir uma imagem de qualidade absoluta na mente dos consumidores. A qualidade percebida é um patrimônio intangível da marca que relaciona expectativas e realidade de entrega.

A qualidade percebida proporciona valor para a marca a partir 
do momento em que fornece uma razão ao consumidor para a compra, promove diferenciação perante a concorrência, ajuda a marca a estabelecer um posicionamento de mercado, fornece condições para maior lucro - seja através de maiores preços ou de uma amplificação da base de usuários, torna a marca mais atrativa perante os canais de distribuição, possibilita extensões de linha de produtos bem como da marca em novos mercados (AAKER, 2003).

Os consumidores podem avaliar a qualidade da marca baseados em dimensões subjacentes ao produto, que podem ser favorecidas através do design de embalagens, visto que o design contribui para a formação de uma percepção de qualidade superior. Essas dimensões são: 1) o desempenho; 2) a conformidade; 3) a confiabilidade; 4) a durabilidade; 5) a estética ou design e 6) a empatia do consumidor (MOZOTA, 2003, p.197). Vejamos essas dimensões:

- Desempenho: envolve as características operacionais primárias do produto (KOTLER, 2000, p.78: AAKER, 1998, p.95). A embalagem pode intervir na percepção de desempenho do produto quando é projetada para maximizar seu funcionamento, sua aplicação, uso-manuseio, armazenamento e descarte. O formato ergonomicamente projetado a fim de facilitar a interação homem-sistema, o sistema informativo de design que instrui ao uso ou o projeto estrutural que favorece o armazenamento e o descarte, são formas de influenciar a qualidade percebida de uma marca através da embalagem; 


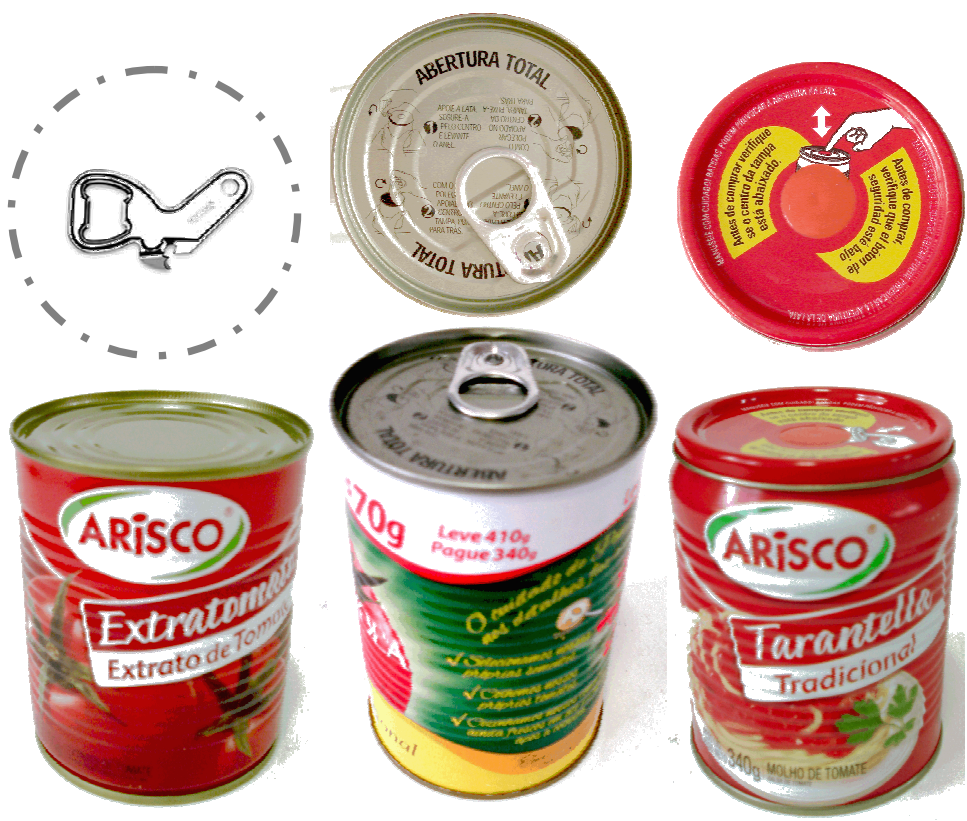

Figura 46: Marcas de molho de tomate têm investido na melhoria do desempenho da marca através de embalagens que buscam facilitar o uso, o manuseio, a abertura e a conservação do produto.

- Conformidade: é a visão tradicional de qualidade de fabricação, compreendendo o pleno atendimento das especificações técnicas de produto (AAKER, 1998, p.95). Embalagens com defeitos podem gerar má percepção de qualidade e de eficiência de produto;

- Confiabilidade: trata-se da probabilidade de um produto não apresentar mau funcionamento em um determinado período de tempo (KOTLER, 2000, p.312). O design de embalagens pode influenciar essa dimensão da qualidade na medida em que apresentar o um bom ou mau funcionamento durante o prazo de vida útil do produto, seja no que se refere ao manuseio, à aplicação, à abertura ou ao fechamento do produto;

- Durabilidade: se refere ao tempo de vida útil do produto (KELLER, 2003, p.238). O desenvolvimento de designs de embalagem que propicie uma maior conservação do produto, seja através de soluções de design estrutural, aplicação de novas matérias-primas ou mesmo sistemas eficientes de abertura e fechamento, tem uma influência

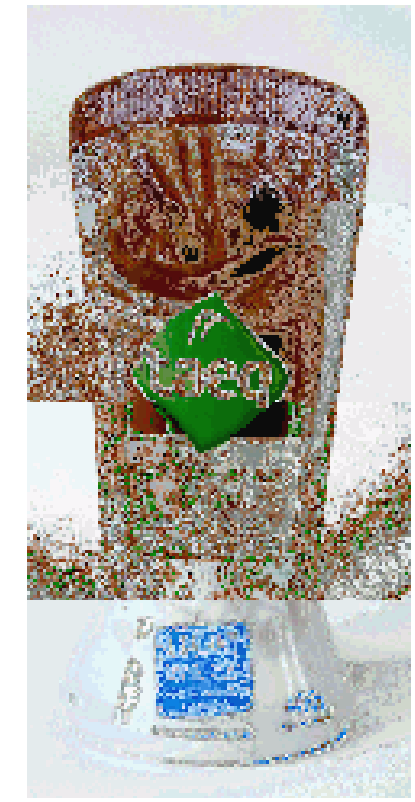

Figura 47: Confiabilidade: do ponto de vista de sistema de informação, o design de embalagens pode também influenciar na construção de uma imagem positiva, inspirando confiança e motivando o consumidor a experimentar a marca - o que deve ser, posteriormente, comprovado pelo desempenho real do produto. Essa tem sido a estratégia adotada por diversas marcas de supermercados, entre as quais Taeq, do grupo Pão de Açúcar: embalagens atraentes para ganhar a confiança do consumidor e gerar experimentação do produto. A embalagem de achocolatado light é extremamente diferenciada da categoria, além de remeter a um corpo humano esbelto, inspirando confiança.. 
direta sobre a percepção de qualidade do produto. Soluções em design de embalagens que busquem trazer um melhor aproveitamento do produto, que melhorem sua conservação aumentando sua vida útil, que informem o nível, a quantidade, o peso, a validade ou o conteúdo do produto de maneira clara e legível ou que instruam o consumidor no uso no que se refere a quantidade ideal de produto e a maximização de resultados, podem fazer a grande diferença na percepção de qualidade da marca no que diz respeito à dimensão "durabilidade";

- Empatia: refere-se ao quanto os consumidores percebem as marcas ou fabricantes como confiáveis, cuidadosos e voltados aos interesses e necessidades dos clientes

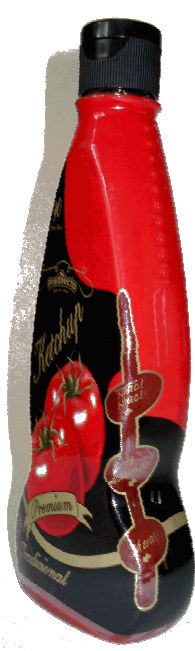

Figura 48: O ketchup Predilecta inova ao trazer uma embalagem que informa o nível de produto, propiciando um melhor aproveitamento: característica que agrega valor à marca na forma de percepção de qualidadedurabilidade.

(KELLER, 2003, p.83). A embalagem constitui uma grande oportunidade de diferenciação e de construção de imagem de marca a partir da entrega de valor adicional ao consumidor na forma de soluções de design apoiadas em um entendimento profundo de seus hábitos $\mathrm{e}$ atitudes, que podem trazer maior simplicidade, conveniência e prazer na compra e uso de produtos.

A percepção dos consumidores sobre essas dimensões pode afetar a qualidade percebida da marca e influenciar suas atitudes e comportamentos. Assim, o design de embalagens tem um papel determinante na construção de imagem do produto, seja criando uma oportunidade de experimentação, ao motivar a repetição de compra e até mesmo influenciar na lealdade à marca.
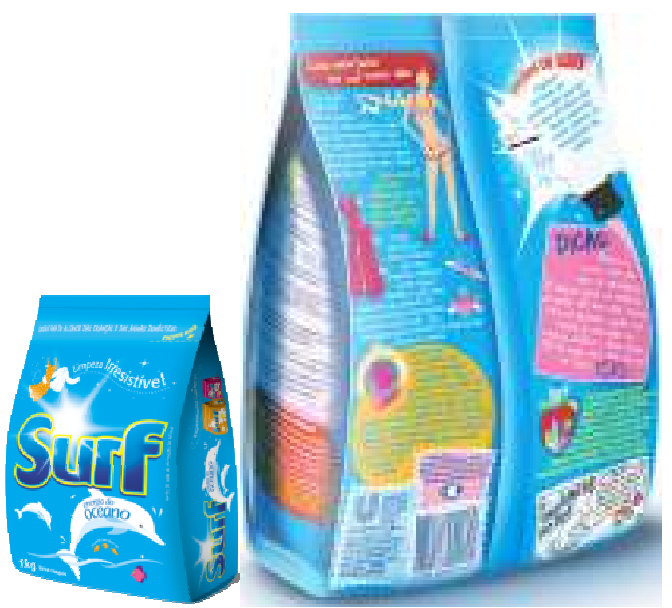

Figura 49: $\mathrm{Na}$ embalagem do detergente Surf, por exemplo, a parte posterior da embalagem é utilizada para trazer aos consumidores dicas úteis e divertidas sobre beleza moda, cidadania, meio ambiente e obviamente, sobre limpeza!

Embalagem que informa e entretém pode ajudar a criar empatia junto ao consumidor. 
Para tanto, Klimchuck (2006, p.41) afirma que o design de embalagem não pode cometer falhas junto ao consumidor final, no que se refere às funções de identificação, legibilidade, acuracidade e representação da promessa:

- Identificação: o sistema de design de informação deve ser desenvolvido de modo a facilitar o reconhecimento da marca, do produto e de suas propriedades e aplicações, reduzindo a possibilidade de confusões na hora da compra. A similaridade do design ao da concorrência ou entre versões de uma mesma linha, por exemplo, devem ser evitados;

- Legibilidade e clareza de informações: 0 design deve primar pela facilidade de leitura e de linguagem,

especialmente no que se refere à função do produto e suas instruções de uso. É imprescindível atentar para o tipo de público ao qual $\mathrm{o}$ produto se destina: produtos para idosos demandam

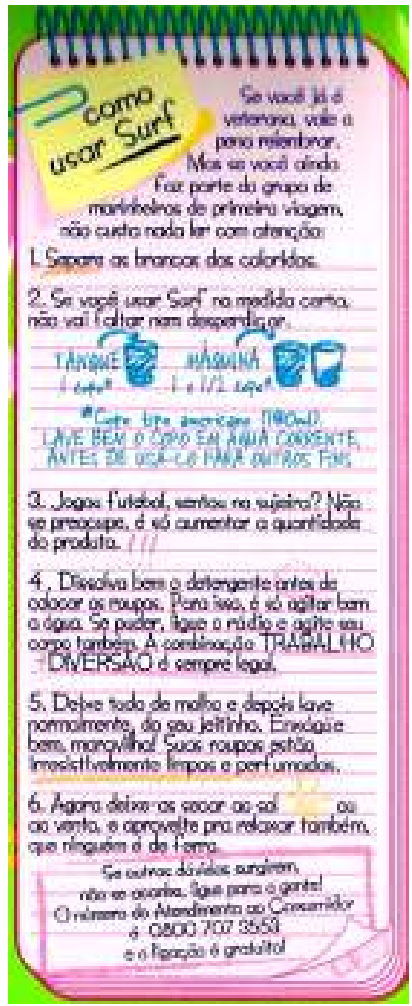

textos maiores, produtos para classes sociais com menor grau de instrução, demandam sistemas de informação mais didáticos, ilustrativos;

- Acuracidade de conteúdo informativo: instruções, especificações técnicas, restrições e informações

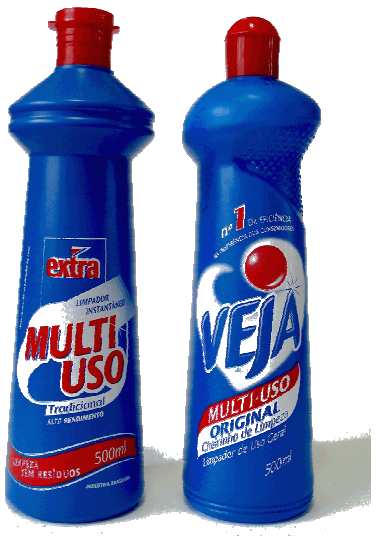

Figura 50: Multiuso da rede varejista Extra: similaridade com o líder da categoria Veja, que pode confundir o consumidor: estratégia de venda ou falha de design?

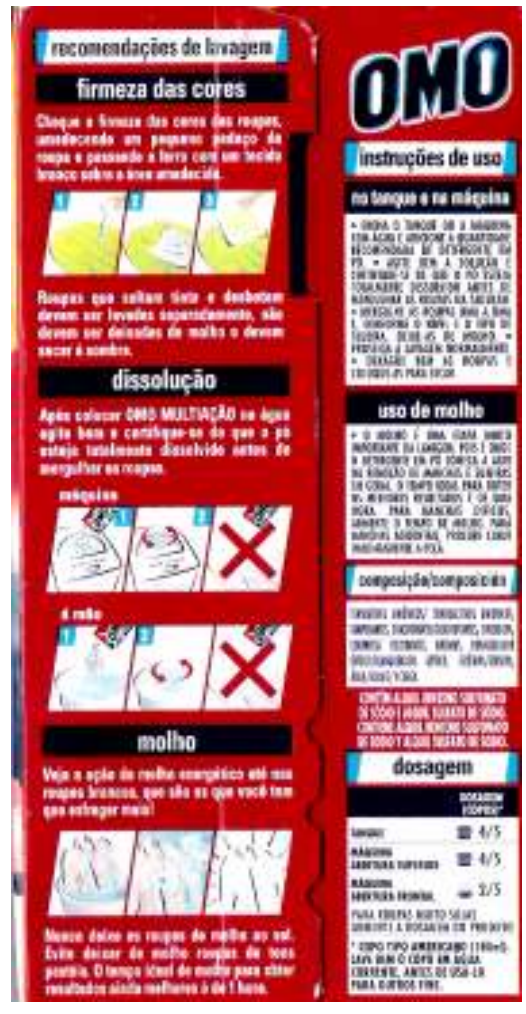

Figura 51: Instruções Surf mais simples e didáticas do que as de OMO. 
legais devem ser informadas corretamente;

- Representação da Promessa: a comunicação de atributos, benefícios e/ou conteúdo de produto devem ser condizentes com a realidade, de modo a não criar expectativas no consumidor que não possam ser atendidas pela marca. Por exemplo, uma foto apelativa que não condiz com a aparência do conteúdo real da embalagem, ou ainda, uma imagem mostrando resultados superiores às possibilidades reais

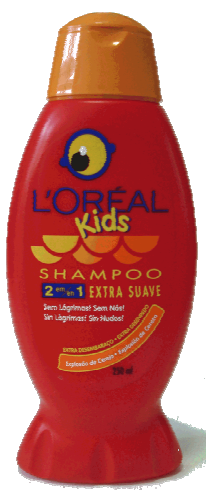
O produto retratado na embalagem deve ser condizente com o real. de desempenho do produto, podem gerar ruídos de imagem para a marca e causar insatisfação.

A percepção de qualidade também está relacionada à percepção de valor.

O valor pode ser definido como a diferença entre o valor total para o cliente e o custo para o cliente. O valor total é o conjunto de benefícios que os clientes esperam de um determinado produto ou serviço. O custo total é o conjunto de custos em que os consumidores esperam incorrer para avaliar, obter, utilizar e descartar um produto ou serviço (KOTLER, 2000, p.56). Resumindo, trata-se da equação "custos versus benefícios".

Os consumidores avaliam qual oferta proporciona maior valor e procuram maximizar esse valor dentro de seus limites como receita, mobilidade, conhecimento, etc. A probabilidade de satisfação e repetição de compra depende da oferta atender ou não a essa expectativa de valor. (KOTLER, 2000, p.56). 
As associações dos consumidores a respeito do valor percebido são freqüentemente importantes fatores de decisão de compra e podem ser influenciadas pelo design da embalagem.

O design da embalagem pode se transformar em fonte geradora de valor adicional ao consumidor a partir da adição de elementos inesperados ou "fatores de excitação" (BAXTER, 1998), constituindo um grande aliado na construção de marcas à medida que endereça necessidades de prazer e envolvimento do consumidor contemporâneo.

Assim, uma estratégia efetiva de adição de valor à marca através do design deve considerar um balanço ideal entre o design da embalagem e o que esse pode oferecer adicionalmente à expectativa do consumidor, a efetividade real do produto, e seu preço. Consumidores consideram pagar mais por uma marca quando eles percebem valor agregado em produtos e serviços, e o design pode agregar valor ao produto neste sentido, seja funcional ou simbolicamente (KELLER, 2003; ELWOOD, 2004).

\section{5 - Embalagens para reforçar a personalidade da marca}

Embora o posicionamento trate de evidenciar as características distintivas em relação à concorrência e motivadoras para o público, tanto na visão de Kapferer (2003, p.88) quanto de Keller (2003, p.150), não dá conta de expressar as singularidades e potencialidades da marca, sendo mudo sobre o tom, o estilo e a forma de comunicação, não considerando a personalidade, os valores e a essência da marca.

A personalidade é o conjunto de características humanas que podem ser associadas a uma marca (MACHADO, 2006). Constitui um conceito tão importante que muitos autores, entre os quais Keller (2003), Ellwood (2004), Kapferer (2003) e Mozota (2003), colocam que a marca verdadeiramente passa a existir somente quando uma personalidade é

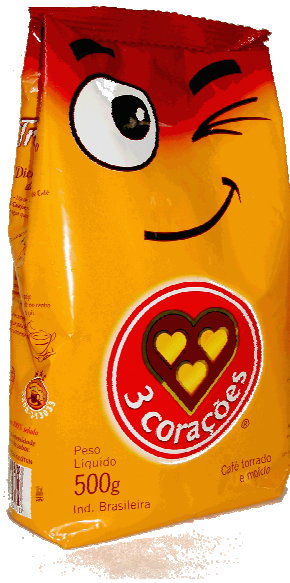

Figura 56: Café 3 corações: embalagem usada para reforçar a personalidade da marca e para criar proximidade com o consumidor: Simpatia, amizade e companheirismo. 
adicionada ao produto, visto que, a partir daí, define uma proposição exclusiva porque cria associações realmente únicas de marca e gera vantagens competitivas para a empresa.

A personalidade da marca se forma a partir das percepções dos consumidores sobre o que a marca faz ou como se apresenta sua identidade. Embora deva ser atribuída à propaganda a maior participação e responsabilidade na formação da personalidade da marca, a embalagem também desempenha um importante papel na formação da personalidade da marca, especialmente quando alinhada ao discurso publicitário.

De acordo com Schmitt (2002, p.185), o desenvolvimento da personalidade se dá por meio da formação de impressões globais nos clientes, cujo significado ou representação para os consumidores pode ser resumido nas seguintes categorias:

- Representações de Tempo: tradicionais, contemporâneas e futurísticas;
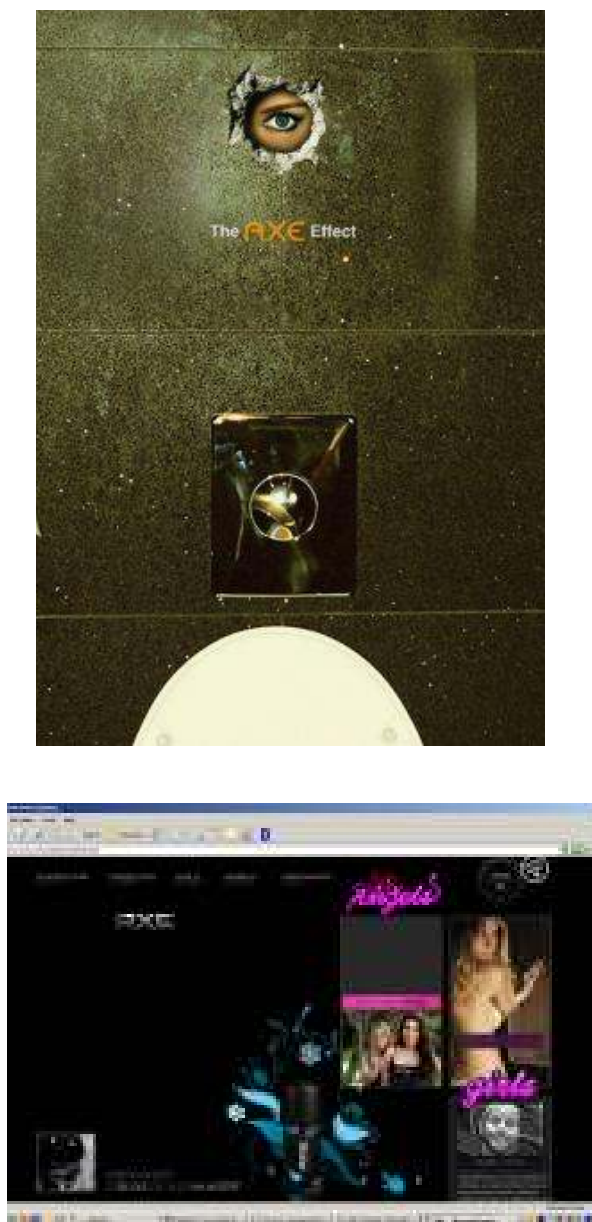

- Representações de Movimento no tempo: vanguarda, Retrô, Legado;

- Representações de Espaço: cidade/país, oriente/ocidente, local/regional, industrial/artesanal;

- Representações Tecnológicas, de Autenticidade, de Sofisticação e de Escala.

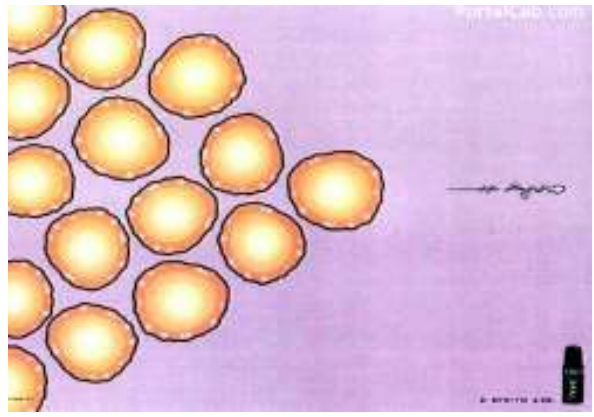

De acordo com Elwood (2004, p.102), o design contemporâneo de embalagens é um dos veículos decisivos na formação da personalidade da marca entre a maioria das marcas de consumo de massa, especialmente quando as mesmas não podem arcar com campanhas na TV, o que ocorre com aproximadamente grande parte do mercado de bens de consumo.

A embalagem enquanto elemento de identidade da marca, deve

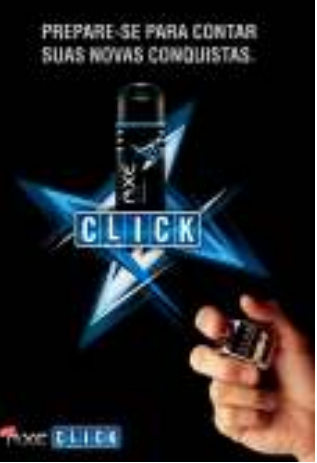

Figura 57: Mídia alternativa (indoor), site e mídias impressas Axe: tema predominante é a conquista feminina. ser melhor aproveitada no sentido de, além de competir gerando 
visibilidade no ponto de venda, deve criar um contato emocional com o consumidor. Seus recursos estéticos devem ser arranjados para envolver os sentidos, humanizar e tangibilizar a marca e, assim, influenciar a experiência de maneira holística, integrada ao discurso da marca, contribuindo para formação de personalidade e conseqüente construção de Equity (GOBÉ, 2002, p.257).

O desodorante Axe exemplifica bem como personalidade da marca se expressa coerentemente através da embalagem. Ao avaliar algumas peças publicitárias, nota-se que Axe aborda os jogos de sedução masculinos, o poder de conquista e a capacidade do produto de transformar qualquer homem em objeto de desejo feminino.

O tema "virilidade" se reflete consistentemente na embalagem, onde cada elemento de design desempenha um papel simbólico com o objetivo de materializar a personalidade de Axe:

- $\quad$ Cores: principalmente o preto, remetendo ao desconhecido, ao misterioso, ao mágico, ao sensual e à noite. Reflete também o lado obscuro das pessoas, o lado não conhecido capaz de atitudes inesperadas;

- $\quad$ Ícone da versão: a versão de nome Conviction (convicção em português), pode ser identificada a partir de uma ilustração semelhante a um espermatozóide, azul, simbolizando a masculinidade, o sexo, o vigor masculino, a criação da vida. O ícone denota movimento, força, brilho, poder;

- Formato estrutural: o formato ergonômico permite uma empunhadura firme, como a de uma arma, o que the confere um ar lúdico. Seu formato fálico completa a dimensão simbólica do produto, reforçando a masculinidade, a sexualidade e o poder - a verdadeira arma

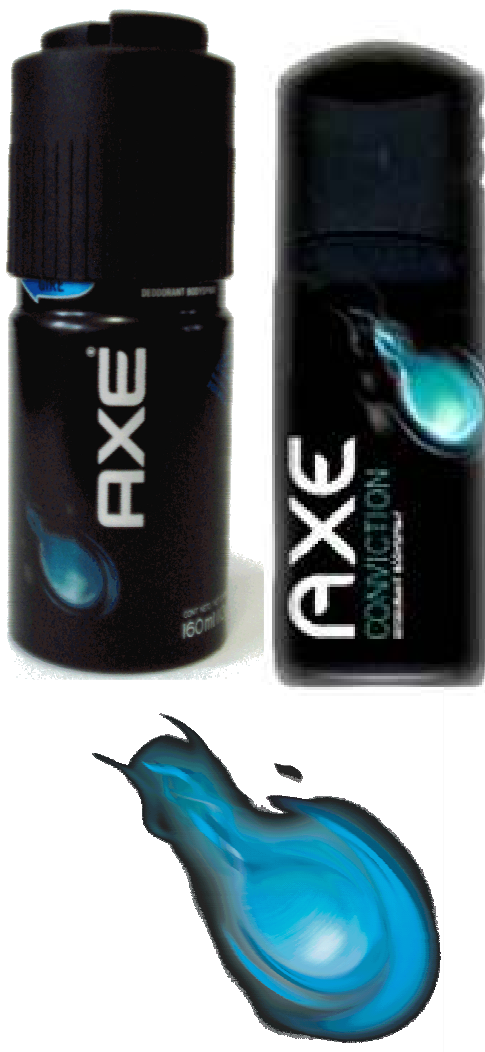

Figura 58: A embalagem de Axe reforça o conceito de virilidade a partir da cor preta, do ícone "espermatozóide" e do formato ergonômico. para a conquista; 
- Personalidade da Marca através da embalagem: masculina, ousada, confiante, irresistível.

A definição da personalidade é uma das informações imprescindíveis ao brief de design de embalagens, visto que, no processo de gestão estratégica do design de embalagens, é necessário garantir que a personalidade da marca, expressa pelo design da embalagem, esteja alinhada à personalidade refletida a partir dos demais meios de comunicação ou expressões marcarias, de modo a potencializar a mensagem.

Além da personalidade, as marcas cultivam valores ou princípios que refletem as atitudes e opiniões explicitadas pela marca e que podem ser resumidas através da essência da marca ou promessa da marca.

Valores são o conjunto de associações abstratas que caracterizam os aspectos ou dimensões mais importantes da marca, com o objetivo de fundamentar sua estratégia, criar um posicionamento diferenciado e, principalmente, suportar a expansão da marca em novas categorias (KELLER, 2003, pg. 150).

Já a essência é um pensamento único que captura a alma de uma marca, o seu verdadeiro significado e o que ela representa. (MOZOTA, 2003; KELLER, 2003).

A embalagem, como elemento de identidade, logo, de comunicação da marca, deve refletir sua essência, assim como as demais expressões marcárias. O alinhamento dos elementos de comunicação da marca em torno de um tema comum, no caso, a essência, possibilita a potencialização da mensagem e, se consistente ao longo do tempo, contribui efetivamente para a construção do Brand

Equity. A essência é o fio condutor no qual a marca se desenvolve.
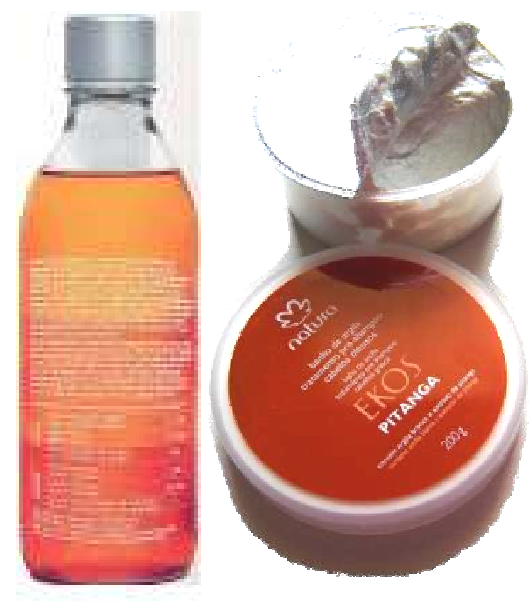

Figura 59: A essência da Natura - Bem estar bem - se reflete minuciosamente em tudo que a marca faz, inclusive nas embalagens de seus produtos, que expressam, de forma consistente, a bandeira da sustentabilidade, do viver bem com o outro e com a natureza para viver bem consigo mesmo, somando associações positivas para a marca. As embalagens da linha Ekos refletem plenamente o conceito a partir, por exemplo, da adoção do formato refil ou mesmo da divulgação da "tabela verde" em seus rótulos, que traz

ao consumidor informações como o percentual de materiais reciclados utilizados na embalagem bem como a descrição dos ingredientes e materiais certificados, obtidos de fontes renováveis (EXAME, 1603-07 Prestação de contas na embalagem). 


\section{6 - A influência da embalagem na lealdade à marca}

Segundo Aaker (1998, p.40), a lealdade à marca é o cerne do Brand equity e representa o nível de ligação do consumidor com a marca, refletindo uma baixa probabilidade do consumidor deixar a marca pela concorrência. Assim, à medida que a lealdade aumenta, a vulnerabilidade da base de consumidores às ações da concorrência diminui.

As principais vantagens para as companhias em desenvolver a lealdade à marca são: sustentabilidade do negócio a longo prazo em função da geração de receitas "garantidas"; redução dos custos de marketing - é muito mais econômico manter um cliente antigo que conquistar um novo; alavancagem comercial, em especial junto aos canais de distribuição; atração de novos consumidores, principalmente pelo "boca-a-boca'; menor vulnerabilidade às ações da concorrência e maior tempo de reação; menor sensibilidade ao fator preço (AAKER, 1998; KELLER, 2003; KAPFERER, 2003; KOTLER, 2000).

O consumidor tem a necessidade de perceber o valor agregado de uma marca para permanecer fiel. Os principais fatores que influenciam a lealdade da marca são a qualidade percebida e os atributos e benefícios do produto. Assim, a lealdade à marca está estreitamente ligada à compra prévia, à experiência de uso do produto, à recompra do produto, à intensidade e à freqüência que essa recompra se dará ao longo do tempo. (AAKER, 1998).

Um dos objetivos fundamentais da embalagem é fazer com que o cliente experimente a marca pela primeira vez e/ou troque a marca que está habituado a comprar. Já no pós-venda, seu papel é gerar lealdade através da adição

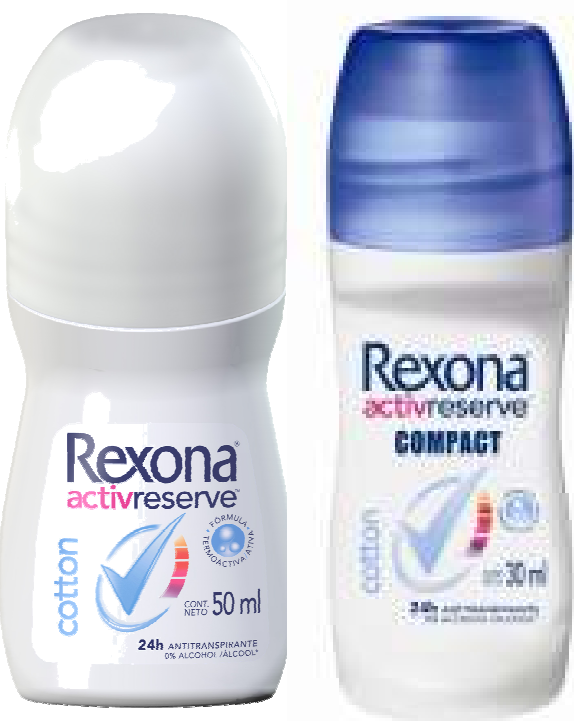

Figura 60: O lançamento do desodorante Rexona COMPACT buscou reduzir os custos de mudança através do desenvolvimento de uma embalagem compacta, menor que as demais embalagens, que além de poder ser carregada facilmente na bolsa, reduz o desembolso financeiro, motivando a experimentação: ao mesmo tempo em que traz novos consumidores para a marca, agrega valor para os usuários atuais, proporcionando-lhes mobilidade do produto, praticidade e conveniência para o usuário. 
de valor à experiência de uso do produto, propiciando sua recompra (ELWOOD, 2004).

Um design atrativo e diferente pode propiciar a experimentação do produto. Isso, segundo Mozota (2003, p.82), acontece porque o design como solução gráfico-formal tem a capacidade de induzir o comportamento do consumidor a partir do processo de percepção, seja através de suas propriedades cognitivas, emocionais, comunicativas e de relacionamento.

Se no pós-venda, entretanto, o produto não desenvolver bem sua função, dificilmente a embalagem poderá, isoladamente, contribuir para a recompra. Ao mesmo tempo, um mau desempenho da embalagem pode comprometer seriamente as chances da marca se estabelecer entre as opções de compra de um consumidor. A válvula entupida de um desodorante, um enlatado que pode ferir o consumidor durante a abertura, um bico dosador que não funciona, instruções de uso ilegíveis ou de difícil compreensão podem contribuir negativamente para a experiência com a marca e, conseqüentemente, para sua imagem, reduzindo as chances de ampliação de consumo do produto.

Convencer o consumidor a provar um novo produto pode ser uma tarefa bastante difícil, mesmo através de uma embalagem persuasiva.

De acordo com alguns autores, entre os quais Aaker (1998), Kapferer (2003) e Keller (2003), ser leal à marca constitui também uma questão de hábito, muitas vezes, alimentado pela necessidade que o consumidor tem de manter-se em uma zona de conforto de consumo, um porto-seguro, aonde o esforço e o risco atrelados ao processo de troca de marca ou de experimentação possam ser evitados, principalmente nos casos em que envolver prejuízo de imagem ou monetário.

Segundo Chetochine (1999), em categorias de alto risco a 
embalagem teria o papel essencial de transmissão da imagem de marca, contribuindo na construção de confiança junto ao consumidor. Já em categorias de médio risco, a embalagem constituiria um dos elementos mais importantes do composto de marketing, visto que nesse mercado o combate se exerce na prateleira, dependendo fortemente do poder persuasivo da embalagem; em categorias de baixo risco a embalagem teria um papel de junto à disposição na gôndola e ao preço, chamar a atenção do consumidor através do impacto.

Produtos categorizados segundo possível prejuízo de imagem ao consumidor:

1) Detergentes em pó: constituem uma categoria de alto risco, pois o resultado depõe a favor ou contra a dona-de-casa - uma família com roupas brancas e limpas são índices de uma mãe zelosa. A embalagem, nesta categoria, deve trabalhar a imagem da marca, gerar identificação e estabelecer uma relação de confiança com o público alvo para poder ser minimamente considerada;

2) Xampus: os consumidores desta categoria têm forte tendência à experimentação, sendo fortemente influenciados pela comunicação da marca e pela embalagem do produto. Entretanto, por se tratar da categoria de beleza, os produtos podem comprometer a aparência dos usuários, constituindo uma categoria de médio risco. O design da embalagem deve ter como prioridade persuadir o comprador, através da comunicação clara dos atributos e benefícios do produto;

3) Papéis Absorventes: podem ser classificados com uma categoria de baixo risco dado o maior envolvimento que demandam por parte do consumidor. Não possuem grandes diferenciais e uma compra errada não implica em conseqüências que possam afetar negativamente a rotina ou a imagem do consumidor. Embalagens para esse tipo de produto devem optar por uma estratégia de visibilidade a fim de propiciar compra por impulso.

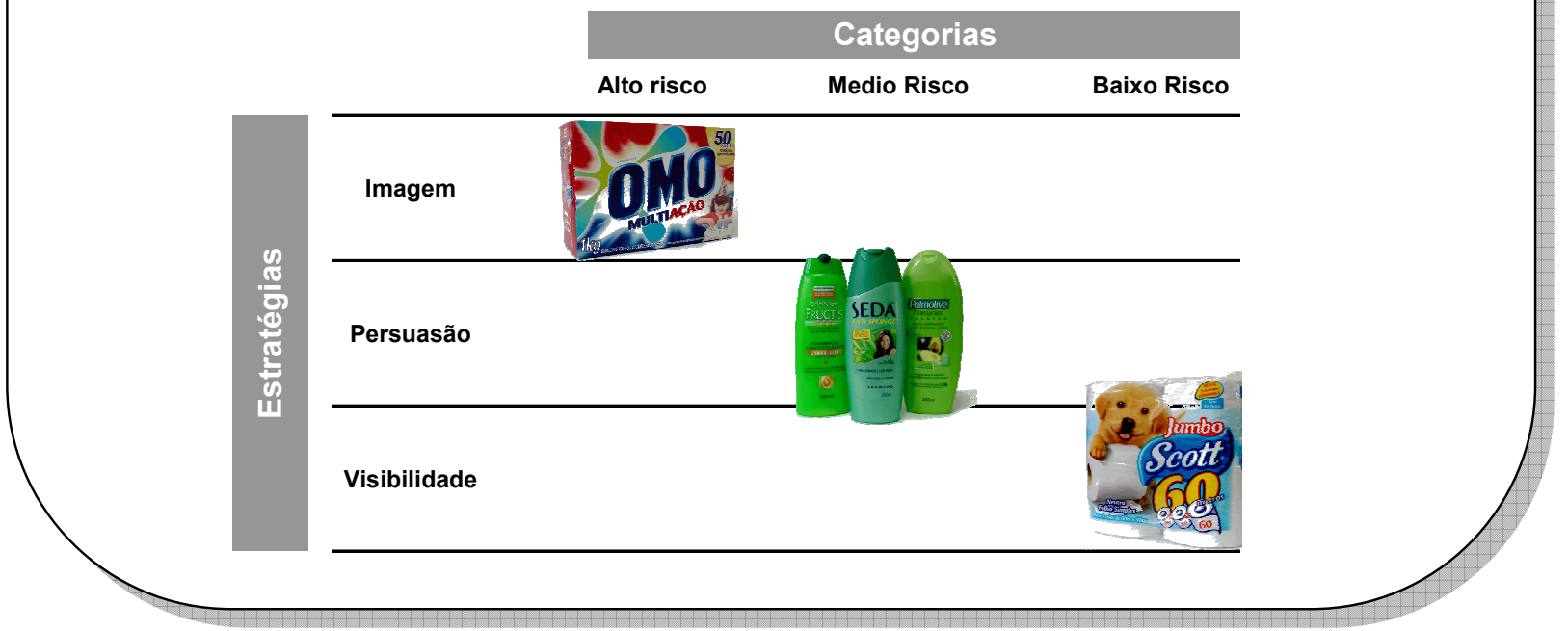

Figura 61: Produtos e riscos atrelados influencias no design de embalagens. 
A motivação à experimentação através da embalagem pode, portanto, ser obtida buscando-se reduzir os custos de mudanças ou proporcionando melhorias na compra, no uso, no manuseio, no armazenamento, no descarte, etc, que tragam um valor adicional para a compra, quebrando o hábito de consumo da marca concorrente.

Assim, ao mesmo tempo em que a embalagem pode motivar o consumidor fiel à outra marca a experimentar um novo produto, constitui uma importante ferramenta de estímulo à lealdade desde que esteja, constantemente, adaptando-se às necessidades do consumidor, evoluindo enquanto interface e gerando valor adicional de compra.

Obviamente que o cliente deverá encontrar valores adicionais que vão além de uma bela e funcional embalagem, para repetir uma compra após a experimentação, e que, necessariamente, estarão relacionados à qualidade percebida do produto, seus atributos, benefícios, seu desempenho, etc. De qualquer forma, a embalagem pode dar ignição não somente a um processo de adição de uma nova marca à cesta de compras do consumidor, mas também favorecer a troca de marcas, bem como contribuir para a recompra e lealdade, visto que impacta na percepção de qualidade e performance do produto.

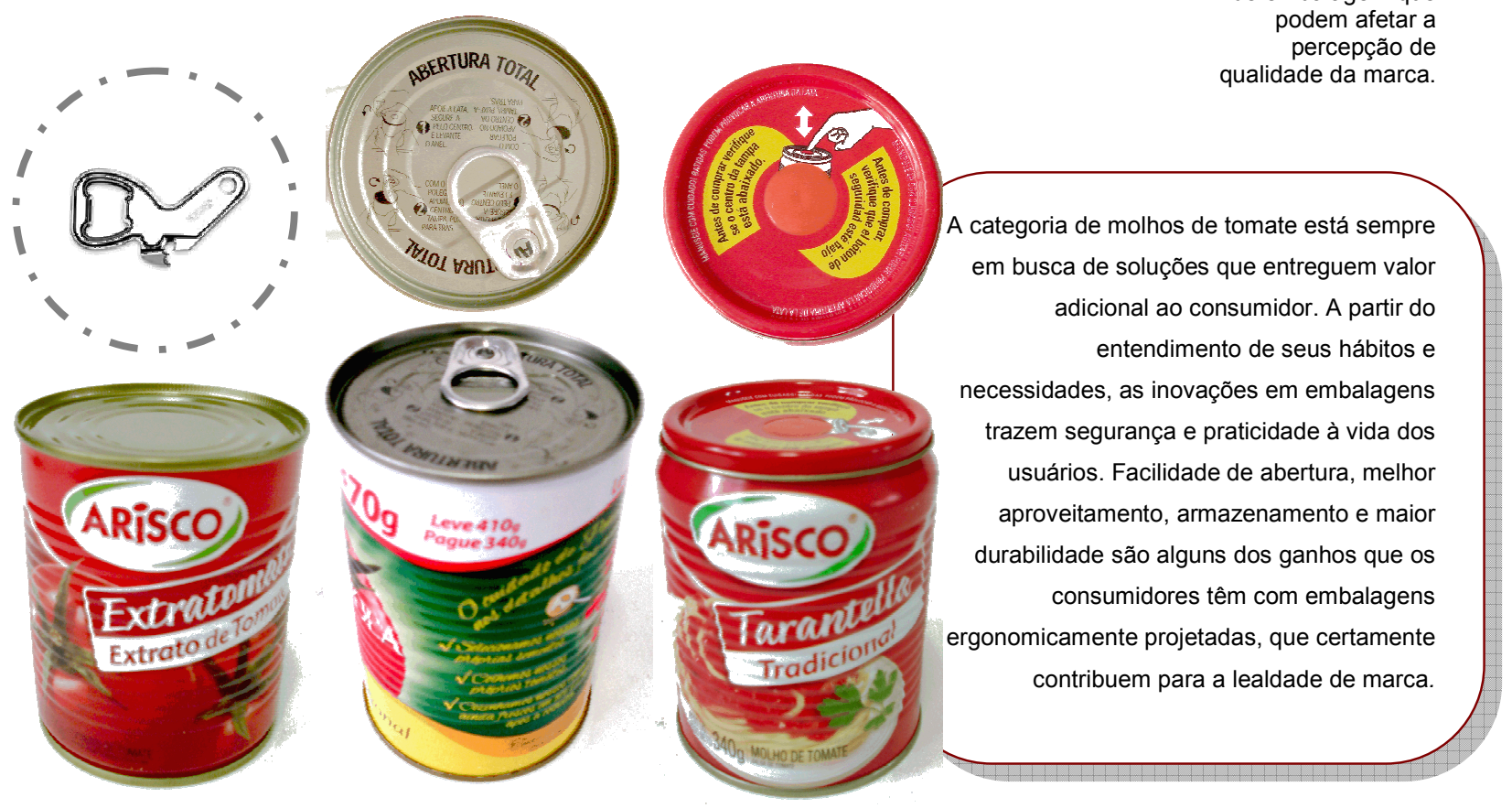

Figura 62: Melhorias de embalagem que podem afetar a percepção de alidade da marca. 
As embalagens são capazes de criar associações para marca o tempo todo e a fortalecer seu Equity: quando expostas no ponto de venda, na interação junto ao consumidor, durante o uso, ou quando armazenadas no lar, contribuindo, assim, para gerar conhecimento, comunicar o posicionamento, para aumentar a percepção de qualidade e influenciar a lealdade de marca, o que se reflete em valor tanto para a companhia quanto para o consumidor.

Mas as embalagens só serão capazes de desempenhar esse papel se seu caráter comunicativo for devidamente manipulado. Se forem geridas como elemento de informação-persuasão dentro de uma mentalidade de gestão estratégica de design, tema a ser tratado no capítulo III. 


\section{Gapítulo 3}

Gerenciamento de Design de Embalagens

As embalagens constituem uma importante ferramenta de comunicação da marca, auxiliando na construção de seu equity. Entretanto, para que seu potencial comunicativo seja integralmente explorado, é necessário que sua gestão aconteça junto ao planejamento da marca, com base em uma abordagem projetual e estratégica.

\section{1 - Gestão Estratégica do Design de embalagens}

Gerenciar o design de embalagem de forma estratégica significa inserí-lo no programa de planejamento da marca, processo em que se definem os diferenciadores essenciais de uma marca no ambiente competitivo do mercado, com a finalidade de construir, medir e gerir seu patrimônio, garantindo sua sobrevivência e sustentabilidade. (ELWOOD, 2004; KELLER, 2003; MOZOTA, 2003).

Quando o design de embalagens é parte do programa de planejamento, todos os seus esforços e atividades estão focados no processo de materialização da estratégia da marca e no objetivo comum de fornecer um mix exclusivo de valor, tanto para a empresa quanto para o cliente, valor que se traduz em (MOZOTA, 2003, p.142):

- Um design memorável, exclusivo, favorável e estético que proporcione conhecimento, diferencie a oferta e que posicione competitivamente o produto;

- Um design que enderece as necessidades funcionais, simbólicas e estéticas do consumidor;

- Um design que comunique a personalidade, valores, a essência da marca, potencializando sua mensagem de modo a criar identificação junto aos consumidores;

- Um design que melhore o desempenho e a percepção da 
qualidade da marca;

- Um design que maximize o prazer resultante da compra e do uso do produto;

- Um design que contribua para a construção do Equity da marca.
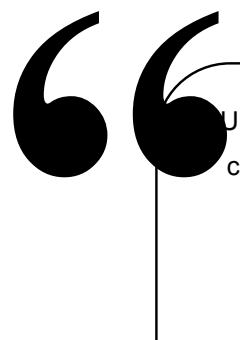

ma das funções da embalagem é propiciar, na medida do possível, prazer na

compra e no consumo. Nós temos prazer em conviver com marcas.Todos nós desenvolvemos uma relação de recompensa com os produtos e é aí que a embalagem pode agregar valor.

Acho que o papel sutilíssimo, mas muito nobre da embalagem é entender onde que essa recompensa. $\mathrm{O}$ design da embalagem ajuda o consumidor a se reencontrar com o seu desejo. Sergio Guardado da Seragini Farne Guardado Design ${ }^{14}$

E para que seja efetiva, a gestão estratégica do design de embalagens deve objetivar: 1) consistência entre a solução gráficoformal da embalagem e a identidade da marca; 2) consistência entre a solução gráfico-formal da embalagem e a estratégia de negócios e 3) coerência entre solução gráfico-formal da embalagem e o posicionamento do produto e/ou da marca, buscando maximizar uma imagem global (MOZOTA, 2003, p.247).

Logo, o sucesso de uma política de gestão estratégica de design de embalagens implica no gerenciamento da pesquisa, do planejamento, da organização, da avaliação e da comunicação visual de informações com o intuito de criar significado e ressonância para a marca, de modo que o design de embalagens se traduz, em sentido lato, em design de informação.

\footnotetext{
14 Informações concedidas à autora através de entrevista realizada em São Paulo, entre os meses de agosto e novembro de 2007, cujo conteúdo integral encontra-se na seção Anexos dessa dissertação.
} 


\begin{abstract}
Chamamos de design de informação a todos aquelas mensagens transmissoras de conteúdos complexos. (...) O design de informação abrange, de fato, todo o conjunto de recursos gráficos, bem como formas de linguagem visual, que são suscetíveis de serem aplicados e combinados na elaboração de uma classe de mensagens informacionais (COSTA, 1994, P.19).
\end{abstract}

Assim, muito mais do que senso estético, é necessário que os profissionais envolvidos nesse processo incorporem uma cultura projetual, ausente de subjetivismos e fundamentada em informações relevantes e consistentes, a fim de que a embalagem cumpra com suas funções.

De acordo com Panizza (2004) o processo projetual serve como um guia de referências na busca de soluções para um determinado problema, sendo que seu principal papel é "criar condições favoráveis para que o pensamento criativo encontre um terreno fértil e seguro para se desenvolver".

O processo projetual está intrinsecamente ligado ao binômio problema-solução, sendo composto das seguintes etapas: (1) delimitação do problema; (2) coleta geral de dados; (3) incubação e ideação (fase correspondente à busca de soluções) e (4) verificação ou análise crítica da idéia.

A gestão estratégica do design ${ }^{15}$ de embalagens consiste, portanto, na gestão do processo projetual ${ }^{16}$ do design de embalagens, de seus agentes e instrumentos de ação, de modo a maximizar o potencial comunicativo da embalagem, a serviço da marca e/ou do produto, e do consumidor.

\footnotetext{
${ }^{15}$ Para efeito de maior clareza de definições, usaremos o termo design para expressar tanto forma quanto processo.

16 Não considera a fase de viabilização e implementação da solução de design, normalmente liderada pelas áreas de pesquisa e desenvolvimento (P\&D), produção, logística e distribuição.
} 

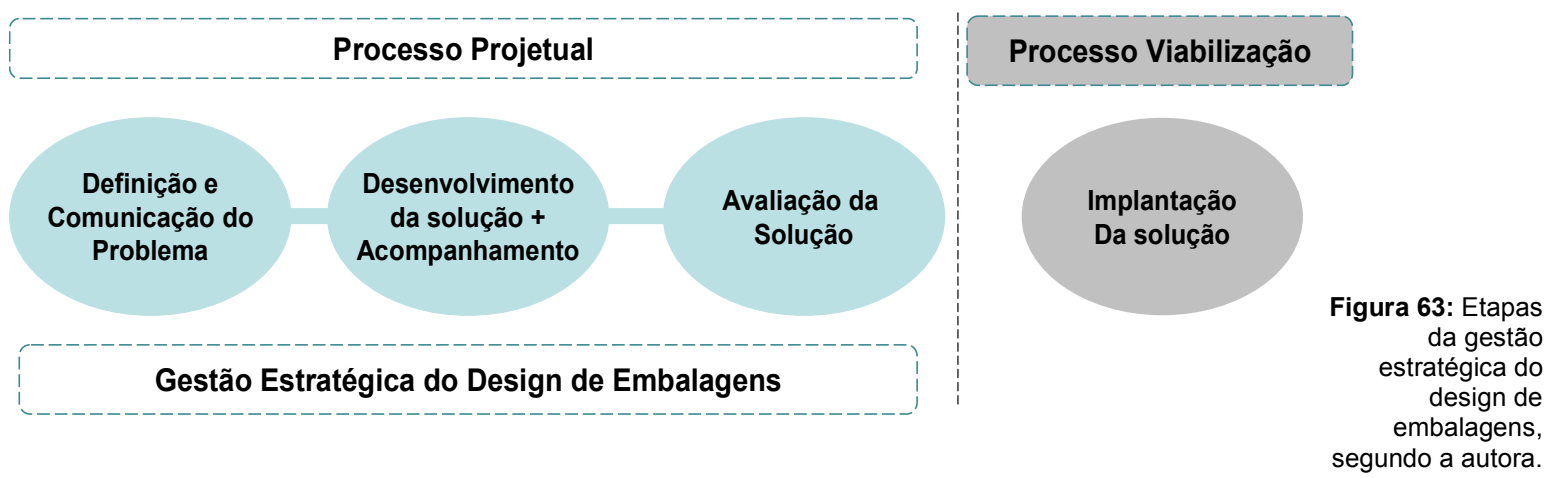

\section{2 - Processos, instrumentos e responsabilidades na gestão}

estratégica de design de embalagens.

O desenvolvimento de uma nova embalagem é um processo complexo dentro da estrutura organizacional, exigindo a participação de várias áreas no alcance de resultados favoráveis à marca e, conseqüentemente, à empresa.

Isso porque a embalagem possui um espectro amplo de atuação, caracterizado fundamentalmente pela interface com áreas que possuem escopos de atuação distintos como marketing, P\&D (pesquisa e desenvolvimento), jurídico, cadeia de suprimentos, logística e distribuição.

Devido à sua amplitude de funções, que vão da contenção do produto, passando pela comunicação no ponto de venda até o descarte responsável, o desenvolvimento de embalagens não caracteriza uma tarefa fácil, constituindo uma resultante da qualidade de integração e alinhamento entre as áreas de interface, assim como do atendimento dos diferentes objetivos existentes. 


\section{Áreas de Interface}

Marketing (Mkt)

Marca e Produtos

Pesquisa de Mercado

Design (interna ou terceirizada)

Agência de Publicidade

Vendas

Pesquisa e Desenvolvimento (P\&D)

Desenvolvimento de Produto

Desenvolvimento de Embalagens

Engenharia ou Tecnologia

Jurídico e Regulatório*

Cadeia de Suprimentos (CS)

Compras

Produção

Logística e Distribuição

(*) Areas de suporte de Pesquisa e Desenvolvimento
Objetivos

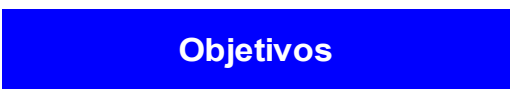

Motivação e Satisfação do Consumidor

Execução do produto com qualidade $\mathrm{e}$ geração de valor para a empresa

Qualidadade e efetividade de custos na produção, no fornecimento e na entrega do produto

Apesar de lidar com objetivos específicos diferentes, as áreas ${ }^{17}$ devem ter como objetivo comum:

- Trabalhar de maneira integrada e comprometida, propiciando um design de embalagens completo, no menor prazo possível;

- Estabelecer uma mentalidade de inovação, o que significa assumir uma postura crítica e desafiadora no processo, buscando viabilizar novas idéias e soluções;

- Fortalecer o relacionamento com os fornecedores e entre os fornecedores, sejam as agências de design, fornecedores de matérias-primas ou suprimentos de embalagem - com isso, os prazos e riscos de projeto e de implantação serão minimizados;

\footnotetext{
${ }^{17}$ As áreas foram aqui agrupadas e classificadas de acordo com os objetivos almejados no processo de design de embalagens e não em função das estruturas hierárquicas ou organogramas comumente utilizados no mercado. A área de design, se interna, não necessariamente está sob a direção de marketing, podendo também ser encontrada sob a área de P\&D ou como um núcleo distinto. O mesmo acontece com a área de vendas.
} 
- Almejar a melhor solução em design de embalagens, criando valor durante toda a "cadeia de embalagem" (ZELENISK apud MEYERS; GERSTMAN, 2005, p. 173).
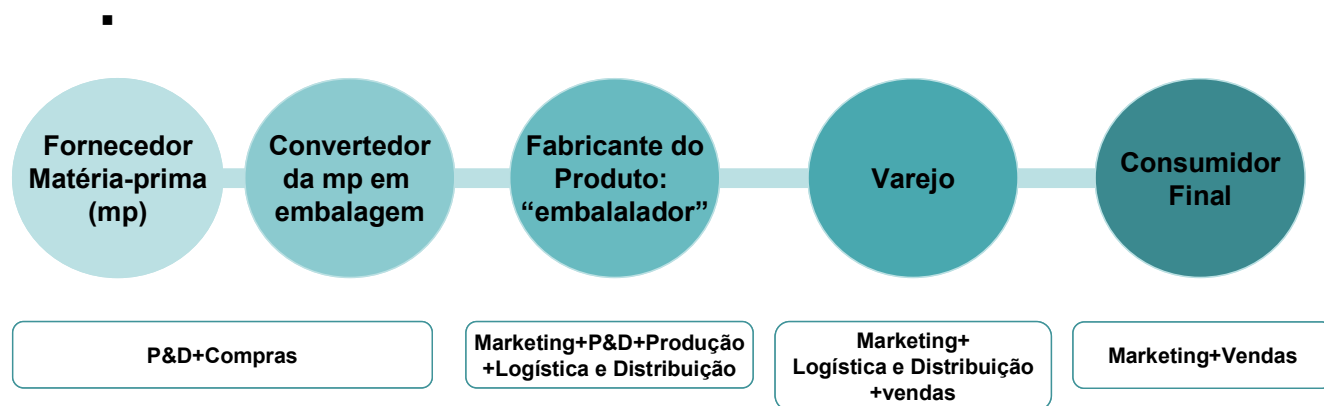

Figura 65:

Cadeia de valor da embalagem

e as áreas internas envolvidas

Por ser um processo extenso e complexo, a gestão de design de embalagens não funciona sem uma liderança claramente estabelecida. De acordo com as atuais práticas de mercado, a área de marketing é a responsável por liderar o processo de design de novas embalagens, o que inclui o desenvolvimento e apresentação do brief, a aprovação final da solução de design, sua validação, bem como o envolvimento das áreas pertinentes no processo.

Quanto ao grau hierárquico dessa liderança, não há uma posição claramente definida. No processo de briefing, encontram-se desde gerentes de produto até diretores de marketing desempenhando esse papel. De acordo com Baroni da Design Absoluto, o importante é que os profissionais responsáveis pela aprovação estejam envolvidos em todas as fases do processo, do briefing à entrega do projeto e à aprovação, de modo que o fluxo das atividades e a tomada de decisões sejam consistentes e coerentes.

O processo nasce na definição do problema de design de embalagens, cuja responsabilidade está a cargo da área de marketing, com o suporte das áreas de pesquisa e desenvolvimento e cadeia de suprimentos.

A definição do problema se materializa sob a forma de um

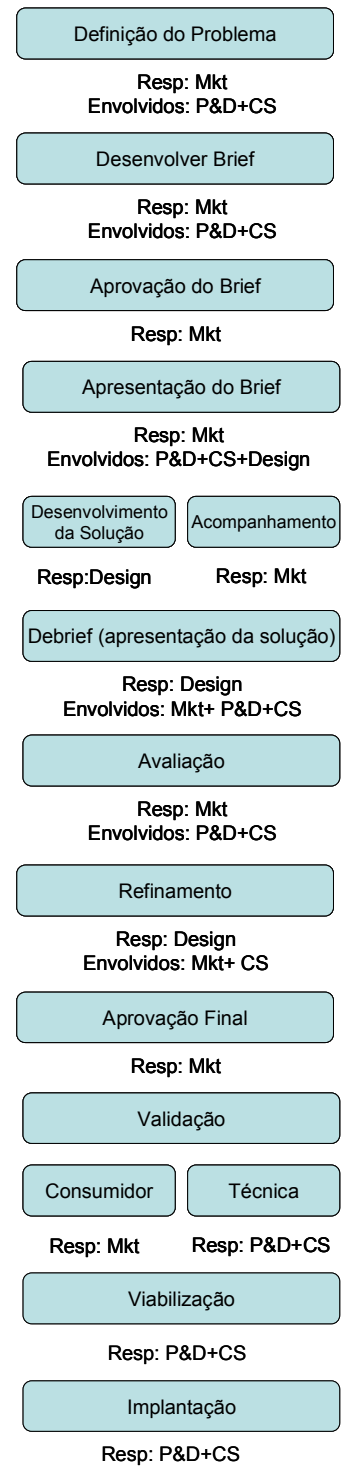

Figura 66: Processo de gestão estratégica do design de embalagens, áreas responsáveis e áreas envolvidas (segundo a autora). 
brief $f^{18}$, documento redigido pela área de marketing que contém as informações necessárias para o desenvolvimento da embalagem e que comunica à área de design, seja ela interna ou externa (escritório, agência...), quais as necessidades e expectativas com relação à nova embalagem.

Após a apresentação do brief, a área de design deve aprofundar a coleta de dados e informações e iniciar o processo criativo, caracterizado pela incubação e ideação, na busca de soluções que serão, posteriormente, apresentadas para o cliente - marketing. Durante a fase de criação, a área de design não necessariamente se isola do processo, podendo haver troca de informações junto á marketing, configurando uma etapa também de acompanhamento.

Após a apresentação das soluções de design de embalagens, a área de marketing avalia a embalagem em relação ao brief e, se necessário, solicita refinamentos. O grau de participação das áreas de P\&D e da cadeia de suprimentos na fase de avaliação varia de acordo com a complexidade técnica envolvida no novo design: alterações estruturais normalmente exigem um maior envolvimento técnico do que as alterações gráficas.

Uma vez aprovada, a embalagem deve ser validada tecnicamente. Já a validação com o consumidor é uma decisão que pode variar em função dos objetivos e riscos atrelados ao projeto.

É partir dessa visão de processo que o design ganha um escopo, uma função ampliada, não se restringindo somente ao processo criativo dentro da agência ou do departamento de design. O design passa a desempenhar um papel de mediador entre as funções de marketing ligadas ao desenvolvimento de embalagens, sendo, nesse contexto, plenamente afetado não somente pela qualidade da

\footnotetext{
${ }^{18}$ Para efeito de maior clareza de conceitos, considera-se brief o documento escrito e briefing, o processo.
} 
delimitação da problemática, materializada no brief, mas também pela qualidade de avaliação, que vai determinar sua aprovação. $O$ design começa, portanto, com o processo de planejamento da marca e termina em uma avaliação que deve ir além de requisitos estéticos; o design de embalagens começa e termina no marketing.

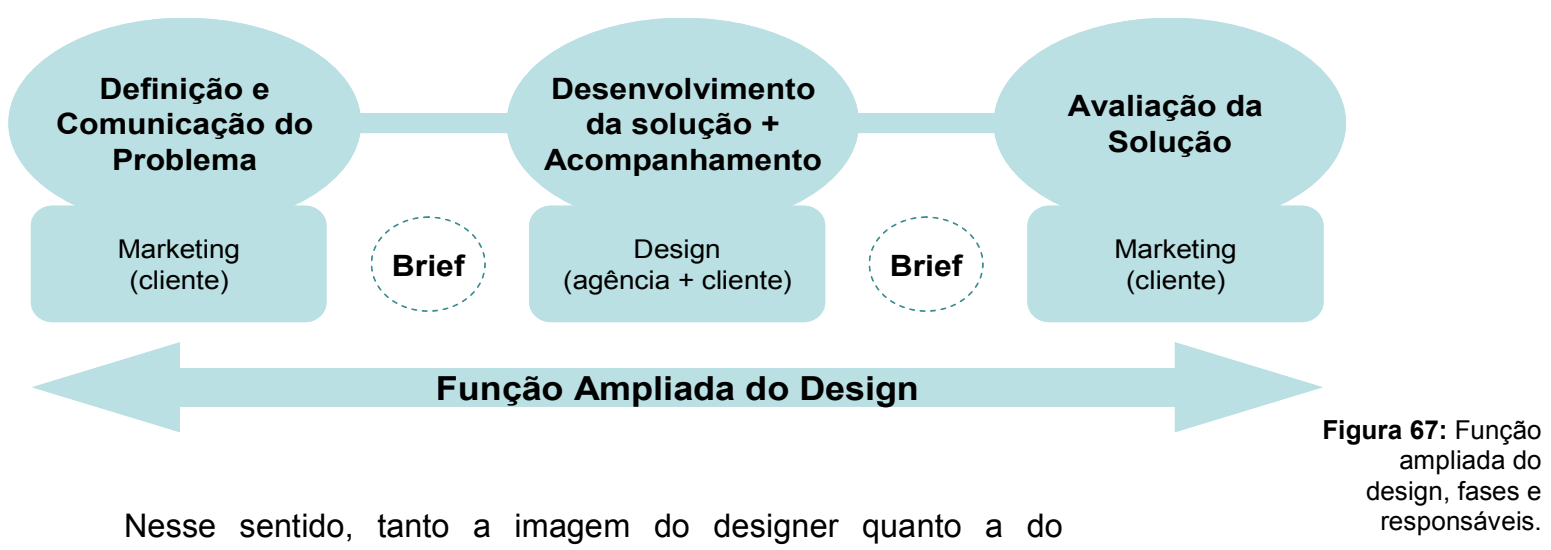

profissional de marketing ganham novas dimensões. O designer, mais do que talento artístico, deve ser capaz de compreender as abordagens de marketing, transformando as informações mercadológicas, marcárias, técnicas e orçamentárias do brief em design de embalagens, em design de informação; já o profissional de marketing também detém responsabilidade sobre o resultado do design, devendo ser capaz de desenvolver um brief de qualidade, fornecendo as informações relevantes ao designer, e de proceder uma análise focada e objetiva.

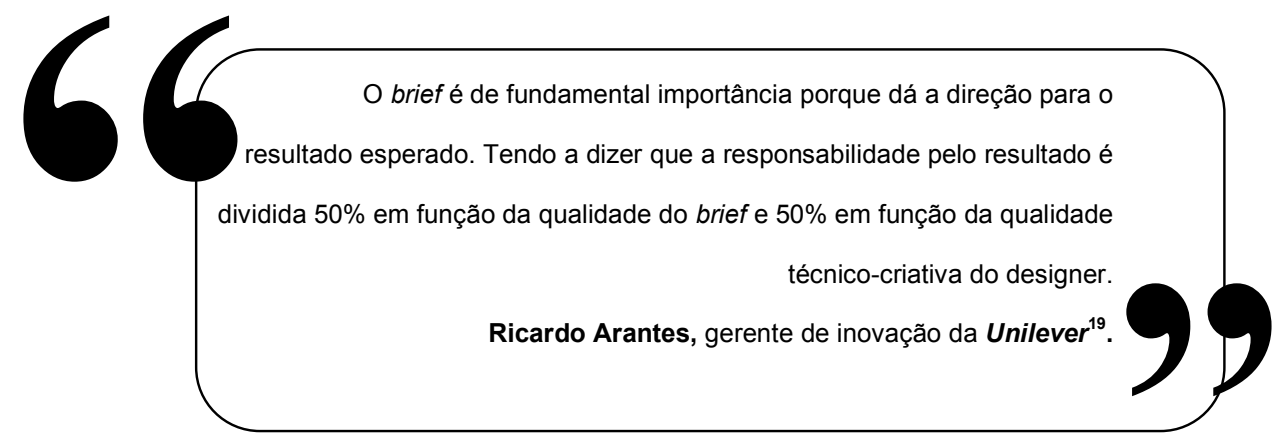

\footnotetext{
19 Informações concedidas à autora através de entrevista realizada em São Paulo, entre os meses de agosto e novembro de 2007, cujo conteúdo integral encontra-se na seção Anexos dessa dissertação.
} 
É imprescindível, portanto, compreender a importância do brief no design de embalagens, quais informações devem ser consideradas, como deve ser transmitido e como as informações se conectam aos elementos gráfico-formais, influenciando o resultado final do processo.

\section{3 - Definição do Problema - Brief para design de embalagens}

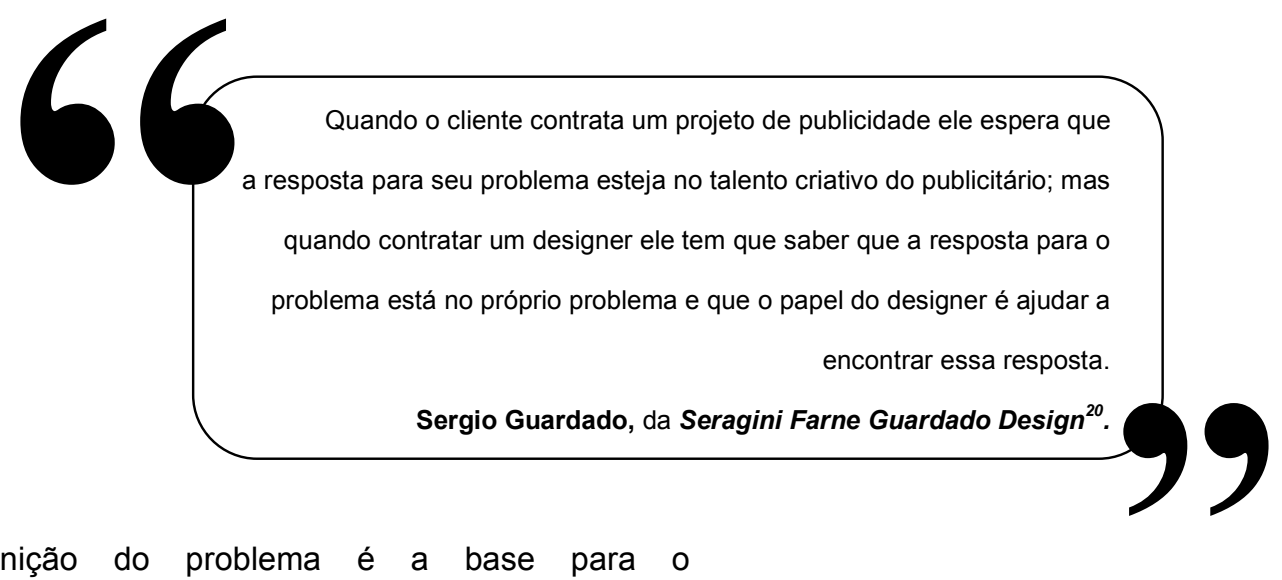

desenvolvimento de um design de embalagens efetivo, afinal, o design é, por natureza, uma disciplina focada no binômio problema-solução, e um brief completo é aquele que consegue determinar com profundidade e riqueza as nuances do problema em questão e o caminho aonde se quer chegar.

De acordo com Baxter (1998, p.60-62), o processo criativo de design está intimamente ligado à determinação de um mapa do problema, a partir do qual é possível determinar seus objetivos, suas fronteiras e metas, bem como à avaliação de soluções que melhor se encaixem no espaço de definição da problemática.

Logo, a solução para um problema de design, na maioria das

\footnotetext{
20 Informações concedidas à autora através de entrevista realizada em São Paulo, entre os meses de agosto e novembro de 2007, cujo conteúdo integral encontra-se na seção Anexos dessa dissertação.
} 
vezes, revela-se no próprio conteúdo do brief. De modo que, se os limites do problema não forem bem estabelecidos, a solução encontrada pode não ser a mais efetiva dentre as possibilidades existentes.

O brief constitui definitivamente o instrumento fundamental na realização bem sucedida do processo projetual. De modo geral, muitas empresas, pressionadas por prazos, acabam enviando o documento por e-mail quando não reduzindo o brief a uma conversa telefônica. Por tratar-se de um processo bastante sensível, propenso a falhas de comunicação, é importante que a apresentação do brief seja feita através de uma reunião com a agência e com o time multifuncional de projeto, garantindo, assim, clareza e objetividade nas informações prestadas.

Para Zeuner Fraissat, da Design com $Z^{21}$, o brief, para ser efetivo, deve ser fruto de uma grande conversa, aonde o cliente e a agência possam se conhecer profundamente, iniciar um relacionamento e compreender como, juntos, poderão desenvolver uma embalagem que acrescente algum valor à marca.

Para vários profissionais, a qualidade do brief de design de embalagens vem piorando ao longo do tempo, o que tem trazido inúmeros inconvenientes no processo criativo. Isso se deve, principalmente, a um movimento de "juniorização" dos gerentes de marketing, atrelado a um contexto mais competitivo de mercado em que se reduzem os prazos disponíveis para desenvolvimento dos projetos.

Apesar do design de embalagens dar mostras de que vem conquistando espaço no território de marketing, deixando de ser considerado como um artifício meramente decorativo para muitas empresas, poucos são os gestores de marketing que sabem como

\footnotetext{
21 Informações concedidas à autora através de entrevista realizada em São Paulo, entre os meses de agosto e novembro de 2007, cujo conteúdo integral encontra-se na seção Anexos dessa dissertação.
} 
contribuir no processo de design de maneira efetiva; poucos são os gestores que conseguem delimitar os problemas com a clareza e acuracidade necessárias ao processo de briefing.

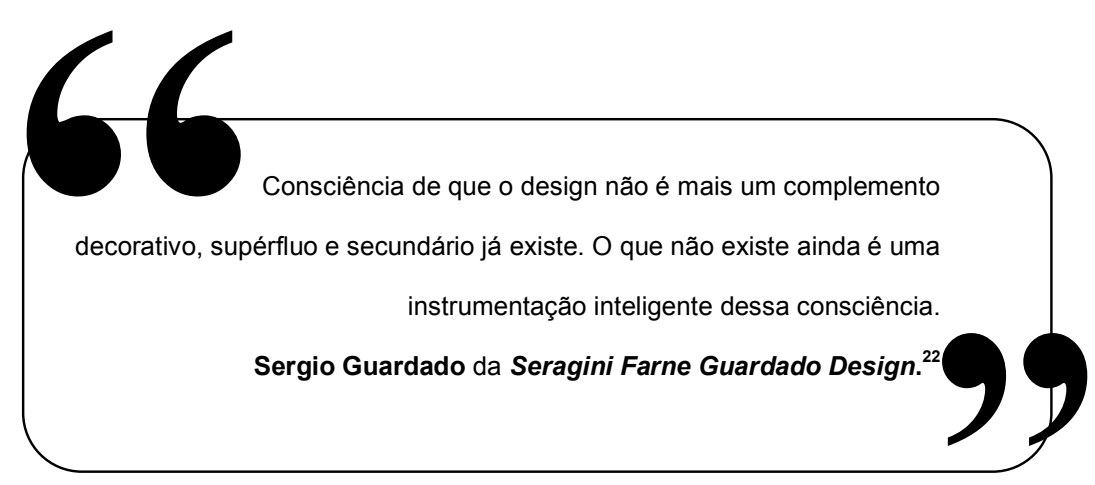

A maior dificuldade para esses gerentes está no entendimento de que o design é um processo projetual, metodológico, que demanda mais de que senso estético e dom artístico. De qualquer forma, o cenário como um todo vem contribuindo para o fortalecimento da figura do designer, cada vez mais presente no processo e que sai da esfera criativa-operacional para envolver-se em uma esfera de planejamentoestratégia, a partir de uma postura questionadora e voltada para o pleno entendimento das necessidades do cliente final - o consumidor. Inúmeros autores sugerem conjuntos de informações que devem estar presentes em um brief de embalagens de modo a melhor qualificar a problemática e a fornecer subsídios sólidos que contribuam no processo de design.

Para Mestriner (2005), é imprescindível considerar no brief os seguintes elementos que garantirão o sucesso de uma embalagem: (1) produto, suas características, diferenciais, qualidade, principais atributos e processos de fabricação; (2) consumidor; (3) mercado; (4) linguagem

\footnotetext{
22 Informações concedidas à autora através de entrevista realizada em São Paulo, entre os meses de agosto e novembro de 2007, cujo conteúdo integral encontra-se na seção Anexos dessa dissertação.
} 
visual da concorrência; (5) limitações técnicas de projeto; (6) objetivos mercadológicos; (7) estratégia de design - qual o papel que se espera que a embalagem cumpra.

Na visão de Keller (2003), um design de embalagem efetivo deveria se basear em 1) um profundo conhecimento do consumidor; 2) o que motiva sua compra; 3) o que ele espera das marcas e produtos; 4) um amplo conhecimento dos canais de distribuição e do que acontece neles - como os clientes vêem a embalagem; qual a dinâmica do canal; como os concorrentes se comportam, etc.

Strehlau (1996) revela que as principais informações utilizadas para o desenvolvimento do design de embalagens são: (1) dados referentes ao consumidor, como perfil demográfico e psicográfico; (2) dados do produto como benefícios e posicionamento de preço; (3) dados da concorrência; (4) métodos de fabricação.

De modo geral, todas as referências anteriores falaram da necessidade de se conhecer o produto, seus benefícios, seus consumidores, o mercado, a concorrência, os canais de distribuição, métodos de fabricação e aspectos legais. Entretanto, é interessante observar que alguns conteúdos imprescindíveis no desenvolvimento de embalagens efetivas não estão normalmente presentes nos briefs, a citar: a compreensão do universo simbólico da marca, sua identidade, personalidade e como as embalagens devem se relacionar com essas questões; qual o papel daquela embalagem como mídia da marca, que objetivos de comunicação deve atender, que objetivos de negócio deve endereçar.

Além disso, algumas tendências apontam uma nova direção no processo de briefing, muito mais interativo, experencial e voltado para uma maior integração com o universo das marcas e do consumidor. 
Para Alessandra Baroni, da Design Absoluto $^{23}$, o brief é o documento que vai nortear o planejamento e a criação do design da embalagem, com o qual se confrontam todas as rotas criativas; para tanto, ele precisa ser inspirador, o que significa ir além das palavras: ir ao supermercado junto com o cliente, acompanhar o processo de compra junto ao consumidor, participar de uma experiência de uso do produto na residência do usuário, entender a percepção que o público tem de determinada marca e quais relações se estabelecem entre ambos (marca e consumidor), são formas de vivenciar o problema de maneira mais aprofundada e que certamente influenciarão positivamente os resultados.

Zeuner Fraissat, da Design com $Z^{24}$, ressalta a importância da cumplicidade entre cliente e agência, bem como de um profundo entendimento do universo da marca como ferramentas essenciais no design de embalagens efetivas. Ou seja, adicionalmente ao conteúdo, é importante pensar como o brief pode tornar-se um documento vivo, experencial, ou seja, como pode ser inspirador no que tange à forma e

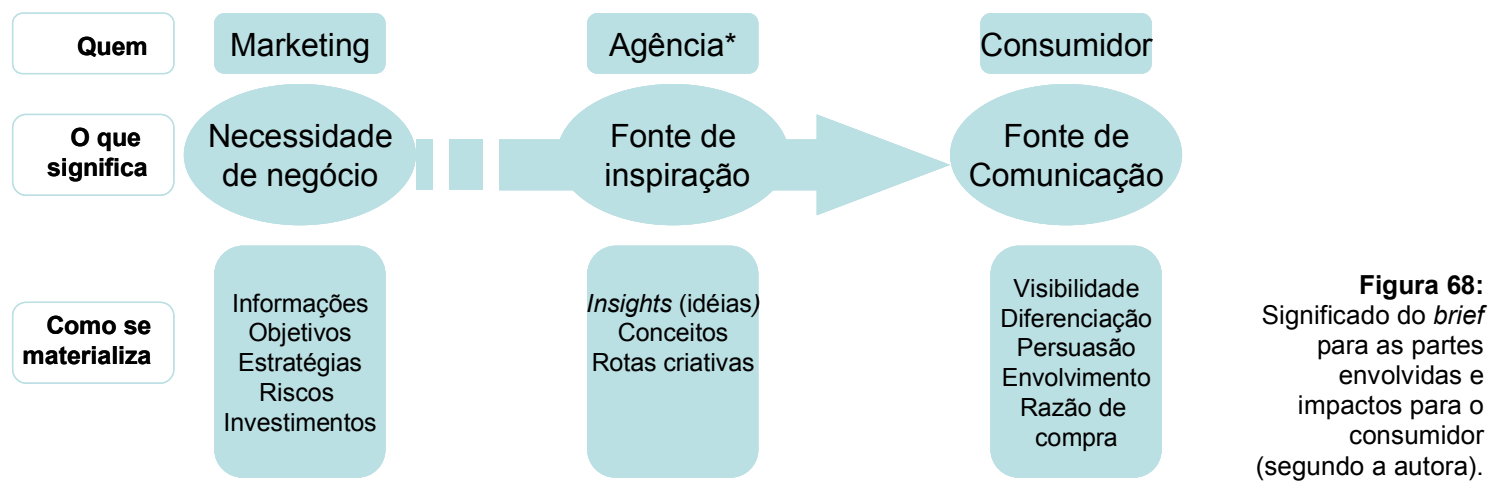

(*) Agencia, escritório, departamento interno ou organizações responsáveis pelo design.

23 Informações concedidas à autora através de entrevista realizada em São Paulo, entre os meses de agosto e novembro de 2007, cujo conteúdo integral encontra-se na seção Anexos dessa dissertação.

24 Informações concedidas à autora através de entrevista realizada em São Paulo, entre os meses de agosto e novembro de 2007, cujo conteúdo integral encontra-se na seção Anexos dessa dissertação. 
como pode colaborar para a sensibilização dos profissionais envolvidos no processo de design.

Ao mesmo tempo em que o brief significa, para á área de marketing, um sumário das necessidades de negócio da marca, ele deve ser capaz de significar, para a agência de design, uma fonte de inspiração, de onde seja possível extrair insights e conceitos criativos que resultarão no design da embalagem, uma fonte de comunicação da marca junto ao consumidor - daí a importância da qualidade do brief no resultado final do design.

A qualidade de um brief de embalagem está, portanto, diretamente relacionada aos seguintes aspectos:

- Profundidade e acuracidade do conteúdo: o brief deve ser instrutivo e informativo de modo a evitar subjetividades e empirismos no processo criativo;

- Conteúdo Focado: as informações, dados e análises apresentados devem ser aqueles relevantes para o design das novas embalagens;

- Conteúdo e forma inspiradores: a maneira, assim como as informações prestadas, pode fazer toda a diferença em um brief de embalagens. Instigar a área de design ou a agência durante a apresentação do brief, de maneira criativa e marcante, pode trazer bons resultados.

Mas, afinal, quais informações devem ser abordadas? Quais as dimensões relevantes para o design da embalagem? O que realmente deve ser levado em conta no desenvolvimento de um brief de modo a resultar em um design de embalagens efetivo?

\subsection{1 - Elementos do brief de design de embalagens}

Com base nas entrevistas realizadas e considerando-se os 
materiais teóricos disponíveis sobre o tema, é possível traçar uma referência de brief, calcada em oito grandes pilares, visando contribuir com o design de embalagens:

- Contextos e objetivos: qual o objetivo do brief e sua razão de ser, quais os resultados esperados?

- Mercado: quais as particularidades da categoria na qual o produto se insere; o cenário competitivo, as características e desempenho das marcas presente nesse mercado?

- Marca: quais os aspectos que determinam e caracterizam a marca e como a embalagem deve se relacionar com estes aspectos:

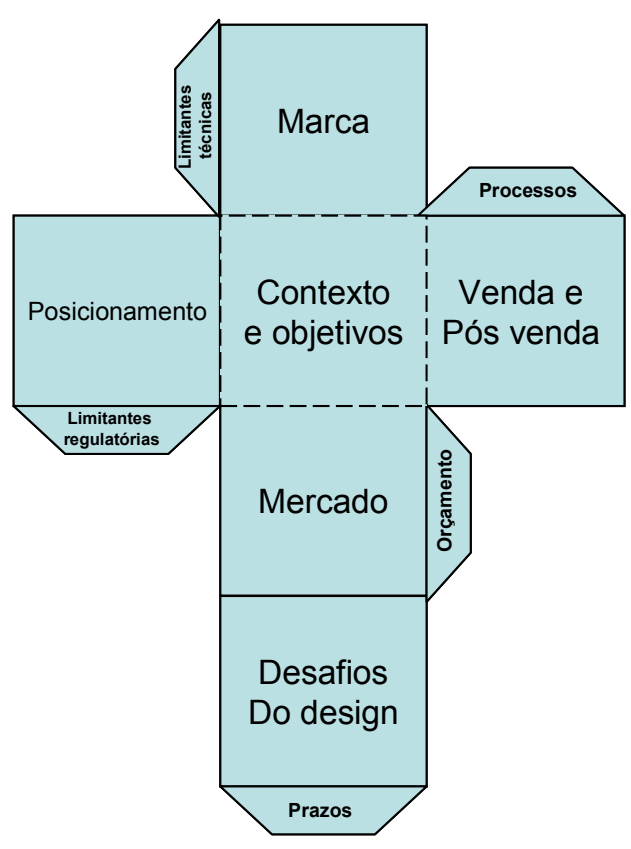

- Posicionamento: qual o posicionamento do produto, quais os atributos e benefícios exclusivos que a embalagem

Figura 69: Pilares do brief de design de embalagens (segundo a autora) necessita transmitir, quem é o público-alvo, perfil, hábitos, atitudes, suas demandas simbólicas e funcionais?

- Venda e pós-venda: como o produto está inserido na dinâmica do varejo e como continua a promover a marca após a compra?

- Desafios para o design de embalagens: qual o papel da embalagem desempenhado atualmente no composto de marketing e quais são as expectativas em relação à embalagem nesse novo contexto?

- Limitações técnicas e informações legais;

- Orçamento, prazos e processo.

\subsubsection{1 - Contexto e objetivos}

É fundamental que as partes envolvidas no processo de briefing e de desenvolvimento de embalagens tenham um entendimento claro no 
que consiste o projeto, em que contexto o projeto se insere, quais são seus principais objetivos, qual é a estratégia de negócio da marca e como o projeto se conecta a isso, quais são os aspectos críticos, os principais desafios, prioridades e oportunidades. Somente, dessa maneira, os resultados obtidos poderão estar plenamente alinhados às expectativas geradas.

Esse é um capítulo extremamente relevante no brief de embalagens, visto que define para o designer a problemática a ser resolvida, aponta possíveis rotas criativas para solucioná-lo, alinha as soluções à estratégia da empresa e delimita os resultados a partir das expectativas de negócios. Se a área de design não estiver a par das dinâmicas atuais do negócio e do modo como a companhia pretende alavancar seus resultados, não será capaz de criar soluções estratégicas de design de embalagens (PHILLIPS, 2004, p.37).

Qual é a estratégia da companhia para esse produto? Estratégia de baixo preço? De alta qualidade? De valor? Sustentabilidade ambiental? Estas informações, por exemplo, podem alterar completamente as rotas criativas de design de embalagem, de modo que compartilhá-las com o time de design é fundamental.

A deficiência de muitos briefs de design está em configurar um compêndio de informações que não são, necessariamente, relevantes para o desenvolvimento de um design efetivo de embalagens. Além disso, muitos se perdem na quantidade de dados, não determinando o que se pretende alcançar com o brief. Daí a importância do profissional de marketing em saber colher, analisar e organizar as informações de modo a facilitar o pleno entendimento por parte do designer do que trata o brief e por que ele está sendo proposto para a área ou agência de design. A qualidade do design da embalagem estará diretamente relacionada a essa clareza de intenções. 
Para uma solução de design ser realmente efetiva, ela deve resolver um problema. [...] O problema deve ser claramente apresentado ao mesmo tempo em que os objetivos de marketing relacionados ao problema devem ser bem articulados. Uma vez que haja um claro entendimento do problema de marketing e de seus objetivos, a estratégia de design poderá ser desenvolvida (PHILLIPS, 2004, p.41, tradução nossa).

A definição dos objetivos do projeto deve estar relacionada aos resultados de negócio, preferencialmente mensuráveis, e não a resultados estéticos. Ao invés de solicitar a criação de uma embalagem mais atrativa e colorida, é importante determinar porque isso é necessário, porque isso pode fazer a diferença e o que a empresa tem deixado de ganhar pelo fato da embalagem não ter essa característica.

Objetivos determinam as necessidades do cliente, mas não as soluções. Um mesmo objetivo pode ter inúmeras maneiras de ser alcançado e é papel do designer recomendar qual a melhor solução de design que se adequa ao problema traçado: melhorar a percepção de qualidade da marca ou de algum atributo peculiar à categoria, reposicionar o produto, aumentar a participação de mercado através de aumento da penetração do produto com determinado público alvo, criar diferenciação e visibilidade no ponto de venda e melhorar o desempenho do produto, são alguns exemplos de objetivos que podem estar presentes em um brief de design de embalagens.

É importante também contextualizar esses objetivos. Aumentar a participação de mercado é um objetivo que pode adotar nuances totalmente diferentes, dependendo do contexto em que esteja inserido um contexto de alta competitividade, de uma nova marca entrando no mercado, de estabilidade nas vendas, de liderança de mercado, etc.

Além disso, deve-se orientar a agência para abrangência que o projeto de design deve tomar - criação de novo lay-out, modernização da linha atual, desenvolvimento estrutural, sugestão de novos materiais, 
etc.

Quando os objetivos são muitos, é importante priorizá-los já que pode não ser possível atender a tudo em uma mesma solução de design. Se os objetivos não forem priorizados pelo cliente, provavelmente o designer irá fazê-los, mas não necessariamente da maneira que o cliente espera.

Ressaltar as oportunidades e desafios do projeto constitui outro grande trunfo dos briefs de qualidade - essas são informações que expandem as possibilidades criativas, ao mesmo tempo em que apontam os caminhos mais seguros, reduzindo tempo e desgaste de energia por parte do time de design.

\begin{tabular}{|c|c|c|}
\hline Objetivo de Negócio & Estratégias de design & Possível aplicação \\
\hline \multirow{4}{*}{$\begin{array}{l}\text { Restaurar a coerência e } \\
\text { clareza do portfólio atual de } \\
\text { produtos através de um } \\
\text { novo design de } \\
\text { embalagens, de modo a } \\
\text { fortalecer o conhecimento } \\
\text { da marca entre os } \\
\text { consumidores }\end{array}$} & $\begin{array}{l}\text { Desenvolver uma palheta de } \\
\text { cores que será usada } \\
\text { consistentemente entre todos } \\
\text { os produtos criando } \\
\text { consistência de linha }\end{array}$ & \multirow{4}{*}{$\begin{array}{c}\text { Embalagens da linha Knorr de caldos - unidade visual } \\
\text { entre os produtos da linha }\end{array}$} \\
\hline & $\begin{array}{c}\text { Criar um código de cores } \\
\text { específico para cada variante } \\
\text { que reforce a arquitetura de } \\
\text { marca } \\
\end{array}$ & \\
\hline & $\begin{array}{c}\text { Desenvolver um sistema } \\
\text { tipográfico novo que possa ser } \\
\text { usado consistentemente em } \\
\text { cada versão }\end{array}$ & \\
\hline & $\begin{array}{l}\text { Desenvolver um novo formato } \\
\text { de embalagens que seja de } \\
\text { propriedade exclusiva da marca }\end{array}$ & \\
\hline
\end{tabular}

\subsubsection{2 - Mercado}

Figura 70: 70 Objetivos de Negócio e estratégias de design possíveis. Adaptado de Phillips (2004, p.147).

A determinação do mercado em que a marca atua é um ponto fundamental no desenvolvimento do brief, visto que pode trazer profundas implicações na efetividade do design da embalagem. 
De acordo com Phillips (2004, p.33), a delimitação do mercado de atuação no brief de design implica em um olhar holístico sobre o negócio e a indicação precisa da indústria na qual o produto ou serviço está envolvido, de modo que pode haver uma considerável diferença entre soluções de design de embalagem criadas para endereçar necessidades de uma empresa que atua na categoria de cosméticos, ou de uma empresa que atua na categoria de bem estar pessoal, embora ambas vendam produtos de beleza.

Além disso, é importante especificar a dinâmica do mercado, provendo ao designer um diagnóstico do cenário em que o produto atua e em que condições o faz:

\section{1) Particularidades do mercado:}

Conhecer as especificidades de um mercado auxilia na elaboração de um design de embalagens estratégico, uma vez que centraliza os esforços de comunicação e de desempenho da embalagem naquilo que é mais relevante e valorizado por esse mercado

Conhecer o ciclo de vida da categoria, por exemplo, pode influenciar na definição da estratégia de design e, conseqüentemente, no projeto final da embalagem. Considere a relação entre design e ciclo de vida proposta por Lidwell, Holden e Butler (2003, p.127): 
Introdução Crescimento Maturidade Declínio

\begin{tabular}{|c|c|c|c|c|}
\hline $\begin{array}{l}\text { vendas altas } \\
\text { vendas médias } \\
\text { vendas baixas }\end{array}$ & & 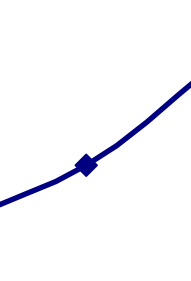 & & \\
\hline Público* & Adotantes Iniciais & Maioria inicial & $\begin{array}{c}\text { Maioria } \\
\text { Posterior }\end{array}$ & Retardatários \\
\hline Mercado & Pequeno & Em crescimento & Grande & Em retração \\
\hline Vendas & Baixas & Altas & Estáveis & Moderadas \\
\hline Concorrência & Baixas & Moderada & Alta & Moderada \\
\hline Foco do Negócio & Conhecimento & $\begin{array}{c}\text { Participação de } \\
\text { Mercado }\end{array}$ & $\begin{array}{c}\text { Retenção de } \\
\text { Usuários }\end{array}$ & Transição \\
\hline Foco do Design & Ajuste & Ampliação & Suporte & Transição \\
\hline
\end{tabular}

(*) Em inglês, respectivamente, Early adopters, Mainstream, Late Adopters, Laggards

Figura 71: Ciclo de vida dos produtos e estratégias de design recomendadas segundo Lidwell, Holden e Butler (2003, p.127):

O foco de design de embalagem em produtos que ainda estão na fase de introdução deve ser o de garantir um desempenho apropriado ao produto, avaliando de perto a interação com o consumidor e propiciando ajustes finos de comunicação, de ergonomia, de manuseio, se necessário. Já no caso de produto na fase de maturidade, deve-se buscar melhorar e redefinir o produto e sua embalagem, de modo a maximizar a satisfação e a retenção de usuários.

Outros fatores a se considerar se referem à relação dos consumidores com o mercado: trata-se de compra planejada ou por impulso? É uma categoria de alto ou baixo envolvimento? Que tipos de risco podem ser observados (econômicos, de imagem, de saúde, etc)? Como é a linguagem visual da categoria? Quais os atributos, benefícios e imaginário básicos, inerentes da categoria? Que características constituem condições de entrada na categoria?

\section{2) Estrutura competitiva de referência:}

Conhecer a concorrência permite ao designer determinar como as marcas conseguiram alcançar o sucesso e onde fracassaram, bem 
como antecipar os próximos passos dos concorrentes de modo a desenvolver uma estratégia de design de embalagens mais competitiva. (BAXTER, 1998, p.119).

É interessante que o brief de embalagens forneça um mapa contemplando as principais marcas atuantes no mercado, os produtos e embalagens ofertados por essas marcas, suas características e benefícios, como se configura a equação de valor e quais os níveis de participação de mercado.

Essas informações devem servir como base para uma análise que permita a identificação das deficiências e fortalezas da concorrência, da percepção do consumidor a respeito desses produtos e das prováveis razões para seu desempenho no mercado, de forma a criar uma estratégia de design mais competitiva.

Outra consideração importante trazida por Mestriner (2005, p.21-22) que deve constar no brief, é a postura que o produto deve adotar frente à concorrência, fator que influencia diretamente a estratégia de design a ser adotada no desenvolvimento da embalagem.

Se o produto compete na posição de liderança, por exemplo, o design da embalagem deve evoluir, mas não mudar drasticamente, principalmente em função do patrimônio visual e do significado de referência segura e confiável que essa marca líder construiu ao longo do tempo.

Por outro lado, se o intuito é que marca concorra diretamente com o líder, a estratégia de design estará focada em oferecer, através da embalagem, algo que o líder não ofereça - inovação em design: materiais melhores ou mais resistentes, novos recursos de impressão e rotulagem, sistemas de abertura, fechamento e dosagem mais eficientes, formatos diferenciados, reutilizáveis, etc.

Já para marcas cujo objetivo é se lançar no mercado, inserindose no ambiente competitivo, a estratégia provavelmente será voltada a 
introduzir a marca na categoria, utilizando-se, principalmente, dos códigos indicativos de categoria já estabelecidos, de modo a ampliar as chances do produto ser considerado para uma experimentação.

\section{3) $O$ produto em relação ao mercado:}

Além de conhecer as particularidades do mercado e o posicionamento dos principais concorrentes, é importante compreender a situação atual do produto, fornecendo uma análise de suas principais características, propriedades e benefícios; como se compara à média da categoria em questão; quais suas debilidade e fortalezas; qual sua imagem perante o consumidor; como vem evoluindo seu desempenho no mercado e por quais razões, bem como suas principais oportunidades e desafio nesse contexto.

Todas essas informações podem fornecer preciosos insights para o desenvolvimento de inovações e/ou melhorias no design das embalagens, incrementando a competitividade.

\section{4) Dinâmica de preço e promoção:}

Como se estabelecem os segmentos de preço da categoria? Como se posicionam as marcas nesses segmentos? Quais as percepções dos consumidores a respeito dos produtos em cada segmento de preço? Como é a relação de valor em cada segmento? Quem são os consumidores em cada segmento?

O posicionamento de preço é outra informação bastante relevante para o desenvolvimento de embalagens efetivas, uma vez que o design da embalagem tem uma influência direta na percepção de preço e valor do produto.

O posicionamento de preço pode ser avaliado também em função do nível de atividades promocionais que a categoria ou o produto praticam. É importante determinar, portanto, se a embalagem, alvo do 
brief, deve ou não ser pensada em função da necessidade de promoções freqüentes.

Há mercados cujos segmentos de preço são bem delimitados e claramente perceptíveis ao consumidor, e outras em que as diferenças são pouco visíveis.

É importante que o designer tenha clareza para qual segmento de preço está desenvolvendo a embalagem, de forma a avaliar quais características refletem os produtos daquele segmento e quais se aplicam ao novo projeto em questão.

O objetivo em dividir esse tipo de informação no brief é evitar que o design seja "superdimensionado" para o posicionamento de preço que o produto pratica.

\section{5) Tendências:}

O brief também deve contemplar, quando possível, as tendências que estão despontando para a categoria de produtos e que poderiam afetar o design da embalagem. Tendências constituem excelentes oportunidades de inovar e de agregar valor através da embalagem

\subsubsection{3 - Marca}

As informações sobre a marca são extremamente relevantes em qualquer brief de comunicação, mas nem por isso são normalmente abordadas, o que constitui um grande empecilho à estratégia de Branding, bem como ao desenvolvimento de embalagens alinhadas ao discurso da marca.

Compreender o universo da marca possibilita ao designer colocar a embalagem em ressonância com a marca, comunicando uma mensagem coesa e complementar ás demais expressões marcárias, de

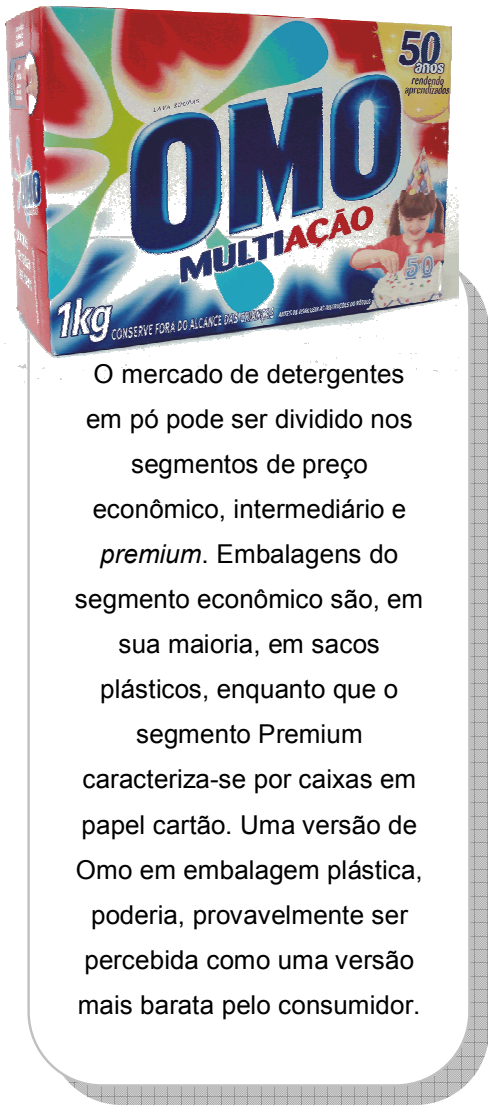

Figura 72:

Influência da embalagem na percepção de preço e valor

do produto

(AINDA) FEITO AQUI:Essa tendência engloba oportunidades para novos e tradicionais fabricantes locais. Em um mundo regrado pela globalização, pela produção de massa e pela guerra de preços, um crescente número de consumidores tem buscado produtos com apelos mais autênticos, que tenham uma história local com a qual se identifiquem e que sejam ecoresponsáveis. Essa poderia ser uma grande oportunidade para desenvolver designs de embalagens com apelo regionalizado ou artesanal!

Still made here. Disponível em: $<$ http://www.trendwatching.com/tre nds>Acesso em 09/12/2007.

Figura 73: Tendências como fontes de inovação em design de embalagens 
modo a potencializar a

comunicação e a gerar uma

imagem de marca consistente

(KAPFERER, 2003, p.83).

Quais os valores da marca?

Em que se resume sua essência?

Como se define sua personalidade?

E a empresa? Qual sua missão?

Sua visão? Sua cultura? Essas são

informações que devem constar no

brief de embalagens para criar um

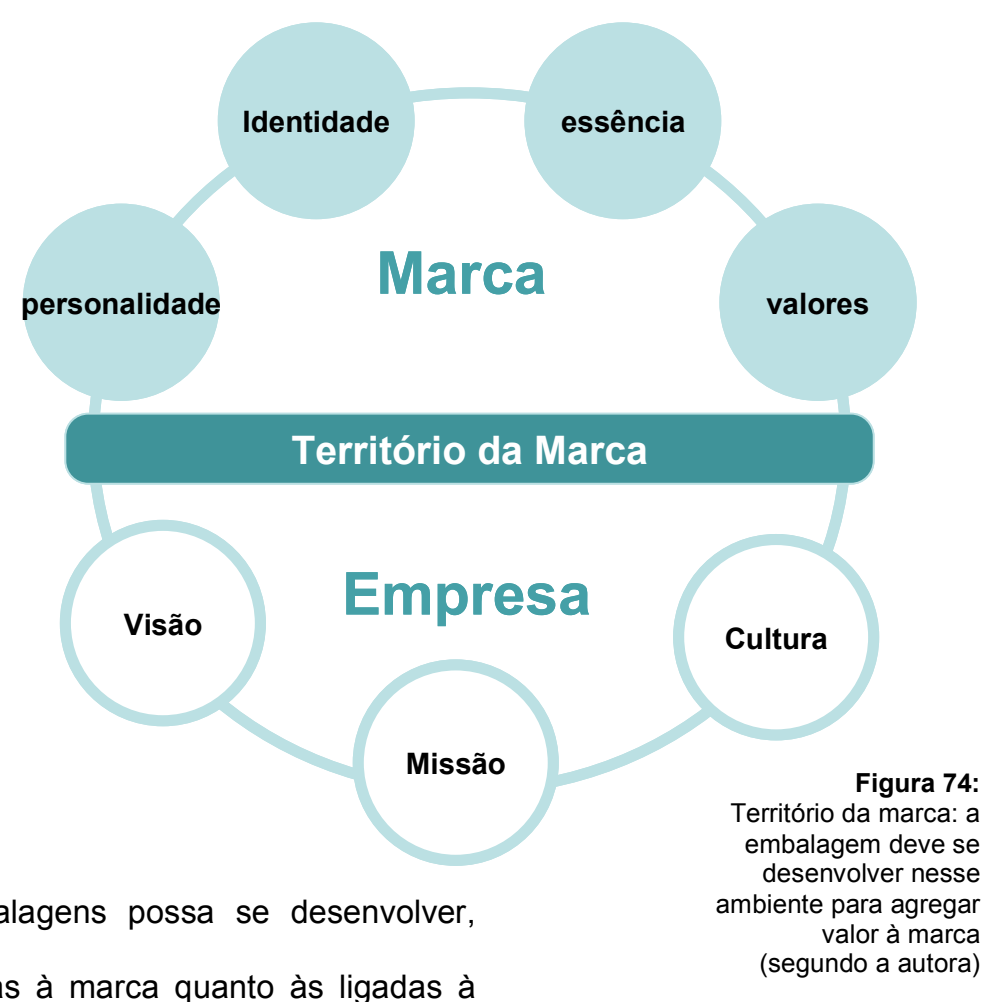

considerando tanto as questões ligadas à marca quanto às ligadas à

empresa, reduzindo-se, portanto, os riscos de execuções equivocadas

que possam implicar em danos de imagem.

As embalagens da linha Ekos da Natura vendem mais do que cosméticos, vendem um estilo de vida, calcado na sustentabilidade, na importância de viver bem consigo e com o mundo para viver melhor. É interessante notar como cada elemento da embalagem transpira essa filosofia: a utilização de materiais reciclados no frasco, no cartucho, tabelas informativas que valorizam a composição de matérias-primas, gastos com energia, processos de reciclagem, refis que se propõem a reduzir o consumo de materiais, design minimalista que se alinha a uma proposta de viver a vida de uma maneira mais simples, saudável e natural. As embalagens podem ser inseridas dentro do território da marca onde questões corporativas, de marca e de produto se unem para materializar embalagens politicamente corretas. 
Zeuner Fraissat, da Design com $Z^{25}$, responsável por vários projetos de design de embalagens para a Natura, coloca que esse tipo de trabalho só é possível quando se conhece claramente a visão, a missão da empresa bem como a marca em essência: "como um ponto de contato, a embalagem deve construir mais do que identidade visual, deve construir uma identidade, linguagem e tom de voz bem como levar a mensagem da marca para os consumidores."

Adicionalmente, é importante compreender o estágio de desenvolvimento que a marca ocupa, já que o design de embalagens pode assumir formas completamente diferentes. Nesse sentido, se a marca está construindo presença no mercado, por exemplo, o design da embalagem poderia ser definido de modo a gerar um maior conhecimento; se precisa aumentar a consideração de uso, a embalagem pode reforçar os atributos de qualidade da marca, melhorar a percepção de desempenho do produto, etc.

Outro fator importante a ser considerado é a imagem da marca - como é percebida atualmente pelos consumidores no que diz respeito a seus atributos emocionais e funcionais? E no que diz respeito à sua personalidade? Existem oportunidades de melhoria? Se parecer parceira e próxima são características importantes para a marca, por exemplo, como a embalagem pode contribuir nesse sentido?

É importante também determinar como a nova embalagem deve integrar-se à arquitetura de marca e ao portifólio de produtos:

- Arquitetura de marca: cada produto detém uma função no portifólio que comunica algo para a marca. É importante determinar como a embalagem vai distinguir esses produtos

\footnotetext{
${ }^{25}$ Informações concedidas à autora através de entrevista realizada em São Paulo, entre os meses de agosto e novembro de 2007, cujo conteúdo integral encontra-se na seção Anexos dessa dissertação.
} 
e, ao mesmo tempo, indicar sua origem única. Como expressar a marca, a submarca, o descritivo de produto, os códigos específicos das versões através da embalagem (KAPFERER, 2003, pg.190);

- Portifólio de produtos: informar quais as versões atuais de produtos, se estão previstas novas extensões de linha e como a nova embalagem deve se integrar à essas estruturas. Uma criação de design para uma versão adicional à linha já existente deve manter a mesma linguagem, tom e personalidade de modo a propiciar unidade à linha, ao mesmo tempo em que deve favorecer os atributos e benefícios específicos daquela versão para minimizar a canibalização da linha, por exemplo.

É importante que o gestor de marketing tenha uma postura próativa no desenvolvimento do briefing, buscando antecipar as necessidades do designer mediante o fornecimento de informações relevantes ao design de embalagens eficazes.

\subsubsection{4 - Posicionamento}

O design da embalagem freqüentemente resume e comunica o posicionamento total da marca, de modo que é imprescindível definir no brief de design o público para o qual o produto se destina; a promessa que envolve essa oferta, seus atributos e benefícios; em que ocasiões seu uso é recomendado.

Há casos, porém, em que não há a necessidade do design da embalagem representar o posicionamento por completo, mas sim enfatizar um aspecto particular, enquanto outras mídias vão divulgar outros diferenciais que se complementam como um todo em um mesmo plano de comunicação (UNILEVER EFFECTIVE PACKAGING, p.14). 
Alessandra Baroni, da Design Absoluto $^{26}$, acredita que o design da embalagem é mais efetivo quando privilegia somente uma informação. Isso porque todos os recursos visuais estarão concentrados em destacar e reforçar aquela mensagem no conceito visual, o que tende a promover um maior impacto e clareza na comunicação, atraindo o consumidor mais rapidamente.

Desse modo, ao mesmo tempo em que a declaração do posicionamento no brief provê um ponto de partida para a avaliação do papel que a embalagem vai desempenhar no plano de comunicação da marca, é importante determinar se a solução de design deve refletir o posicionamento do produto integralmente ou em partes, sob a forma de atributos e benefícios discriminadores da oferta.

Todas as informações fornecidas serão redefinidas pelo designer a partir de um conceito visual obtido através da sintetização das informações em símbolos fortes e concisos, expressos através de uma linguagem memorável, favorável, exclusiva e estética, alinhada à personalidade da marca e do público ao qual o produto se destina e organizados de acordo com uma hierarquia comunicativa.

E à medida que o conceito visual da embalagem for capaz de "contar uma história" ao consumidor, ou seja, de comunicar o conceito do próprio produto e de transmitir uma equação de valor relevante, ele estará contribuindo para construir conhecimento sobre o produto, para posicionar a marca na mente do consumidor, argumentando sobre a promessa e persuadindo à compra.

Dessa forma, cabe ao profissional de marketing informar sobre o posicionamento, determinar quais informações são as mais relevantes e discriminadoras para a marca, e, se necessário, priorizar as informações

\footnotetext{
${ }^{26}$ Informações concedidas à autora através de entrevista realizada em São Paulo, entre os meses de agosto e novembro de 2007, cujo conteúdo integral encontra-se na seção Anexos dessa dissertação.
} 
visto que as soluções de design podem variar completamente de acordo com a qualidade e clareza do conteúdo prestado no brief.

O público alvo, a situação e a razão de uso são importantes tópicos do brief de design, afinal, a embalagem de um produto deve ser desenvolvida para atrair o consumidor e para viabilizar o pleno atendimento às suas necessidades.

A maioria dos briefs de design não denota em detalhes o perfil, as características, hábitos e atitudes dos consumidores, fatores que têm uma influência direta sobre a qualidade da solução de design, podendo até mesmo propiciar a criação de novas formas de apresentação visual, melhorias e/ou inovações de uso, consumo, armazenamento e descarte de produto.

As companhias que não detêm um profundo entendimento do consumidor estão em desvantagem e, como conseqüência, cometem erros freqüentes que poderiam ser evitados. Determinar somente o perfil demográfico e sociográfico de um público alvo é desprezar oportunidades de inovar e de desenvolver embalagem que tenham maior afinidade com esse público.

Entrevistas com o consumidor constituem preciosas fontes de dados e informações no design de novas embalagens. Ir às compras com o consumidor, entender quais são suas motivações de compra, o que chama sua atenção, como ele utiliza o produto, quais características ou benefícios valoriza e como se relaciona com a marca, são algumas das inúmeras possibilidades de contato e de entendimento de suas necessidades, de seu estilo de vida, de seus valores, crenças, etc.

Observar os hábitos das donas-de-casa em relação ao cuidado com as roupas, por exemplo, pode fornecer dicas relevantes para o desenvolvimento de uma nova linha de comunicação visual nas embalagens: o modo como a mãe cuida da roupa dos filhos, o orgulho que sente ao vê-los com roupas limpas, perfumadas e macias, os laços 
de carinho que se fortalecem no ato da limpeza e do cuidado com as roupas poderiam resultar em um conceito criativo que priorizasse a afetividade, a maternidade, a delicadeza em detrimento, por exemplo, da iconologia científica, de força, poder, eficácia.

Além disso, para que o consumidor alvo se identifique com a linguagem da embalagem, logo, com o universo da marca, é preciso entender suas necessidades simbólicas e traduzí-las no produto, traduzí-las na embalagem. Quais seus desejos? Seu estilo de vida? Como projeta sua auto-imagem? A que grupo pertence? Quais seus valores?

O design da embalagem pode dotar o produto da capacidade de transmitir imagens por si próprio ou simbolizar certos traços pessoais de seus usuários. "O simbolismo do produto descreve os valores pessoais e sociais incorporados à aparência do produto" (BAXTER, 1998, p. 151152), de modo que, o design resulta em uma ferramenta fundamental no processo de identificação, ou seja, na projeção da auto-imagem do consumidor e na construção de sua imagem perante a sociedade.

Do ponto de vista estrutural, as possibilidades de melhoria e inovação são ainda maiores - como o consumidor manuseia o produto, como transporta, como armazena, como descarta, podendo resultar em melhores configurações ergonômicas, tamanhos mais adequados, que propiciem mobilidade e reutilização.

A embalagem deve, portanto, comunicar para quem o produto se destina, para qual ocasião de uso e, por fim, qual o benefício que justifica a compra e uso do produto. Para tanto, os seguintes pontos deverão ser considerados no brief: quais são os benefícios mais importantes que justificariam a compra e como eles se apresentam? Quais as razões ou atributos de produto que dão credibilidade a esses benefícios? Existem especificidades de uso e consumo que devam ser comunicadas? Está clara a utilidade do produto, especialmente em 
categorias muito segmentadas?

\subsubsection{5 - Venda e pós-venda}

É importante que o brief reflita qual a expectativa da marca no que tange à exposição no ponto de venda, fornecendo informações que possam ajudar o time de design a desenvolver uma solução apropriada às particularidades da categoria de produtos em questão.

De fato, faz parte das atividades de pesquisa do designer ir ao ponto de venda e compreender como a embalagem se comporta na gôndola, de forma isolada ou comparativa, bem como propor soluções que melhorem sua visibilidade e que estimulem a compra. Entretanto, quando possível, o brief deve contemplar informações como:

- Existe algum tipo de requerimento especial para a exposição na gôndola? De que forma a embalagem é disposta no ponto de venda?

- Qual o nível de material de merchandising na categoria?

- Como funciona a lógica de decisão do consumidor no ponto de venda?

- Trata-se de uma categoria de alto ou baixo envolvimento de compra?

- Como é tamanho aparente da embalagem?

- Qual a ordem de leitura da embalagem?

- Há práticas de picking ${ }^{27}$ que podem comprometer a identificação do produto?

Normalmente, os produtos líderes de vendas ou geradores de tráfego de consumidores na loja são os que detêm os maiores espaços

\footnotetext{
27 Muitas embalagem podem vir a ser abertas no varejo para venda do produto em unidades menores, o que convencionou-se denominar por picking, do inglês, escolher, pinçar.
} 
e melhores posições na gôndola. Já para os demais produtos, os espaços dedicados acabam não sendo os mais visíveis, o que reforça o papel da embalagem em aumentar a visibilidade do produto, ou seja, fazer com que o produto seja percebido pelo consumidor entre os concorrentes (BLESSA, 2005, pg.20).

Com base nesse tipo de informação, o designer poderia, por exemplo, sugerir um novo formato de embalagem, aumentando o tamanho aparente do produto e, em conseqüência,

o facing ${ }^{28}$, desenvolver embalagens display que criem pontos extras de

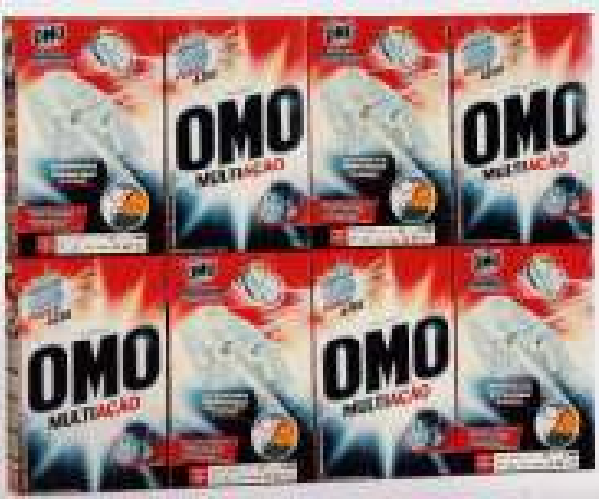

Figura 75: Embalagem venda, ou ainda usar a cor ou a própria arte para criar painéis ou blocos de marca.

Em alguns pontos de varejo, a própria embalagem de despacho pode criar uma oportunidade de comunicação da marca com o consumidor. De posse desse tipo de informação, o designer pode desenvolver, por exemplo, embalagens display que facilitem a exposição do produto.

\subsubsection{6 - Desafios para o design de embalagens}

Essa seção do brief provê ao designer um resumo das expectativas do cliente em relação aos resultados que a embalagem, como mídia de comunicação e interface da marca, deve alcançar junto ao consumidor. Trata-se de uma análise crítica daquilo que está sendo pedido, da real finalidade do novo design solicitado e da viabilidade de alcançar os objetivos estabelecidos.

Como a embalagem é vista atualmente e o que se espera que o consumidor pense ou faça em resposta ao novo design? Se o profissional de marketing for capaz de responder essa pergunta com

\footnotetext{
${ }^{28}$ Participação visual do produto na gôndola ou share of shelf.
} 
clareza no brief, muito dificilmente terá decepções na execução do design da embalagem. Por outro lado, se não for capaz de responder, é melhor revisar o brief e redefinir a problemática.

\subsubsection{7 - Limitações técnicas e informações legais}

É importante relacionar todos os aspectos referentes à produção industrial da embalagem, bem como ao processo de envase, de modo a alcançar resultados de melhor qualidade.

Mestriner (2005, p.45) sugere um checklist de informações imprescindíveis à embalagem que vai ser desenhada. É importante que essa seção do brief seja desenvolvida em conjunto com o engenheiro ou técnico responsável pela área de pesquisa e desenvolvimento em embalagem e em produto, assim como com a área jurídica ou regulatória com o objetivo de constituir um quadro útil e preciso para o time de design.

Embalagem existente

material/características

desenhos técnicos

técnicas de impressão, decoração, rotulagem

número de cores

vernizes e recursos especiais de acabamento

relevos

código de barras, posição, magnitude

fotocélula

lote de fabricação

data/validade

tipo de envase/fechamento

lacre/indicação de abertura

fitilhos/selos/lacres

indicação do fabricante da embalagem/contato

textos legais/tabelas nutricionais

outras informações do cliente

Amostras de embalagem

\section{Nova Embalagem}

Amostras/protótipos do fabricante da embalagem contato do fornecedor da embalagem todos os demais itens da embalagem existente

Figura 77: Checklist da embalagem a ser desenhada (MESTRINER, 2005, p.45). 


\title{
3.3.1.8 - Orçamento, prazos e processo
}

\begin{abstract}
Essa parte do brief fornece detalhes críticos necessários à realização de um processo de design bem estruturado e, conseqüentemente, bem sucedido. Garante que os profissionais envolvidos tenham um entendimento claro de todos os aspectos do projeto e estejam em concordância. Para tanto, é importante (PHILLIPS,
\end{abstract} 2004, p.44):

- Estabelecer atividades e responsáveis no fluxo de desenvolvimento da nova embalagem, do brief à pesquisa de validação do design, se for o caso;

- Fornecer prazos claros e razoáveis para desenvolvimento das tarefas e acordar o cronograma com a agência;

- Informar como se dará o processo de aprovação durante as fases do projeto;

- Delimitar o orçamento disponível para o projeto de design da embalagem.

Assim, o brief constitui um documento de elevada importância no desenvolvimento de designs de embalagens efetivos. A má qualidade do brief certamente influenciará de modo negativo os resultados esperados para o design. O brief deve ser entendido como mais que mera formalidade ou burocracia, deve ser entendido como um instrumento fundamental na gestão estratégica do design de embalagens.

\section{4 - Avaliação de rotas criativas}

Após o briefing, a agência de design se utilizará de metodologias criativo-projetuais para desenvolver uma solução que atenda aos objetivos e às especificidades demandadas pelo cliente. 
O processo de avaliação da solução constitui uma fase crítica do gerenciamento estratégico de design de embalagens, visto que serão tomadas decisões que afetarão diretamente o design da embalagem, e que podem comprometer ou elevar as possibilidades de sucesso no lançamento ou relançamento do produto.

A fase de avaliação compreende não só a avaliação do design da embalagem enquanto objeto de comunicação de marketing, mas enquanto objeto de contenção, de armazenamento, de proteção, de conservação, de transporte, de informação e de uso do produto.

Para tanto, todas as áreas de interface, envolvidas durante a etapa de desenvolvimento do brief - marketing, P\&D e cadeia de suprimentos, devem ser acionadas durante o processo de aprovação da nova embalagem para que, de acordo com seus objetivos específicos, possam aprovar ou reprovar o design apresentado.

Enquanto a avaliação realizada pelas áreas de $P \& D$ e de suprimentos está muito mais centrada em critérios funcionais e econômicos, o que elimina comportamentos subjetivos no processo, a avaliação de marketing, ainda hoje, se apóia em julgamentos pessoais estimulados por uma falta de conhecimento técnico no que tange à comunicação visual, e de priorização entre o que o executivo de marketing pessoalmente acredita ser ideal e o que efetivamente é ideal para o público alvo ao qual o produto se destina bem como para a marca.

Para Sergio Guardado ${ }^{29}$, da Seragini Farne Guardado Design, apesar de uma visível evolução nos critérios de avaliação de design, grande parte dos profissionais de marketing envolvidos nessa dinâmica acaba considerando premissas subjetivas na ponderação do que seja

\footnotetext{
29 Informações concedidas à autora através de entrevista realizada em São Paulo, entre os meses de agosto e novembro de 2007, cujo conteúdo integral encontra-se na seção Anexos dessa dissertação.
} 
um bom ou um mau design de embalagens, aprovando ou reprovando uma idéia baseada no gosto pessoal, desconsiderando a afinidade do público alvo com a proposta, bem como a problemática definida no brief.

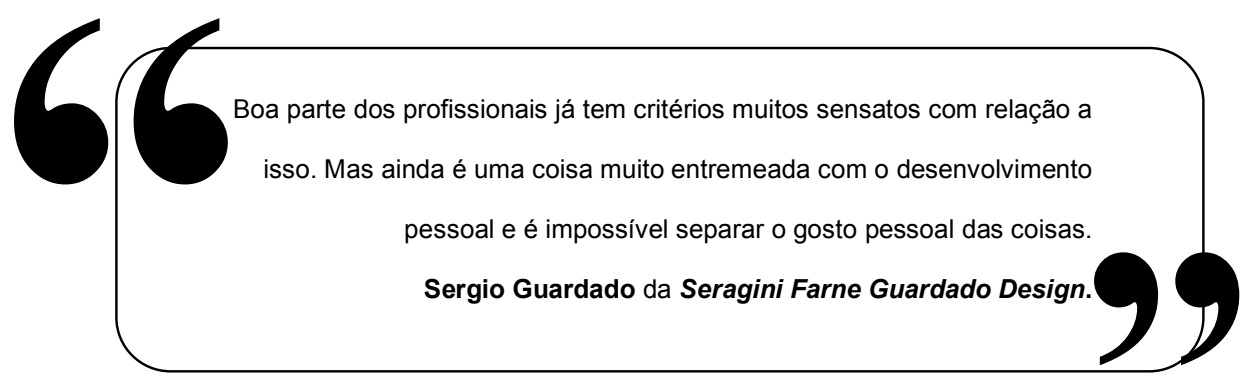

Em linha com a visão de Guardado, Alessandra Baroni, da Design Absoluto $^{30}$ acredita que em muitos casos o consumidor acaba ficando em segundo plano em detrimento de uma visão pessoal do profissional de marketing ou do executivo responsável pela aprovação do projeto de design.

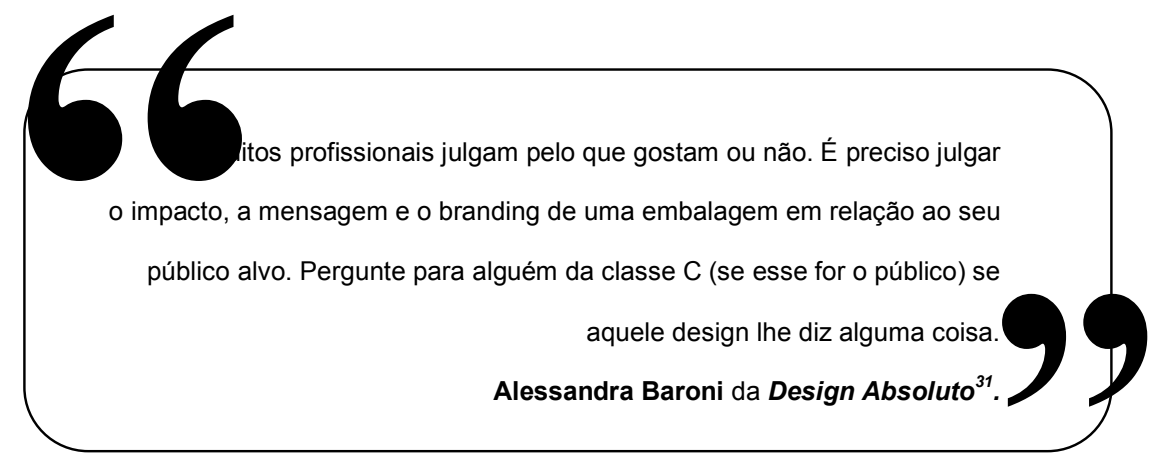

De acordo com Schmitt (2002, p.205-206), a avaliação subjetiva pode levar à soluções de design insatisfatórias por três principais

\footnotetext{
30 Informações concedidas à autora através de entrevista realizada em São Paulo, entre os meses de agosto e novembro de 2007, cujo conteúdo integral encontra-se na seção Anexos dessa dissertação.

31 Informações concedidas à autora através de entrevista realizada em São Paulo, entre os meses de agosto e novembro de 2007, cujo conteúdo integral encontra-se na seção Anexos dessa dissertação.
} 
motivos:

- É limitada e, conseqüentemente, sofre distorções visto que não é abrangente e representativa. Geralmente não envolve muitos exemplos para favorecer uma determinada posição;

- É auto-sustentada, portanto, de confiabilidade questionável uma vez que considera, para sustentação, casos que normalmente foram bem sucedidos;

- É subjetiva, representando a opinião e a intuição de uma única pessoa, sem avaliação e consenso.

Nesse contexto, muitos autores apontam caminhos na direção de uma avaliação mais concreta e coerente do design da embalagem.

Na visão de Keller (2003), por exemplo, a embalagem constitui um elemento de identidade da marca e, assim sendo, seu design deveria ser avaliado em função da sua capacidade de (1) ser facilmente lembrado; (2) transmitir uma mensagem relevante, capaz de gerar associações positivas; (3) propiciar empatia e encantamento através de apelo verbal e visual; (4) ser facilmente adaptável para outros formatos, materiais e tamanhos; (5) ser patenteável ou dificultar cópias, gerando uma diferença tangível e competitiva.

Aaker (1998) considera que qualquer ativo da marca, incluindo a embalagem, deve ser avaliado em função da sua capacidade de 1) gerar lealdade de marca; 2) gerar uma percepção de qualidade superior e 3) criar associações relevantes de marca.

No discurso de Gobé (2002), como ferramenta final de comunicação, a embalagem deveria não só ser capaz de gerar impacto nas gôndolas, mas sim criar um contato emocional com os consumidores para poder ser escolhida e apreciada, devendo ser avaliada em função 1) da clareza com que define o propósito do produto; 2) da adequação da expressão visual à marca e 3) da conexão emocional que cria através de uma mensagem sensorial ou de elemento 
surpresa.

$\mathrm{Na}$ prática, porém, estas considerações ainda reforçam as condutas subjetivas pois é difícil definir o que representa uma embalagem "adequada”, "emocional”, "empática”, "encantadora”.

Por outro lado, Schimitt (2002) pontua a necessidade da aprovação dos elementos de identidade de marca, entre os quais, a embalagem, através de pesquisas com o consumidor. Mas deve caber ao consumidor a árdua tarefa de tomar essa decisão para os profissionais de marketing e de design?

Para muitas empresas, esta acaba sendo, infelizmente, a rota escolhida. Enquanto o papel da pesquisa de design deveria ser o de assistir o processo de desenvolvimento de embalagens, enriquecendo o julgamento e provendo informações adicionais na tomada de decisão, acaba sendo utilizada como um substituto a um processo avaliativo bem estruturado e embasado (UNILEVER EFFECTIVE PACKAGING, p.148).

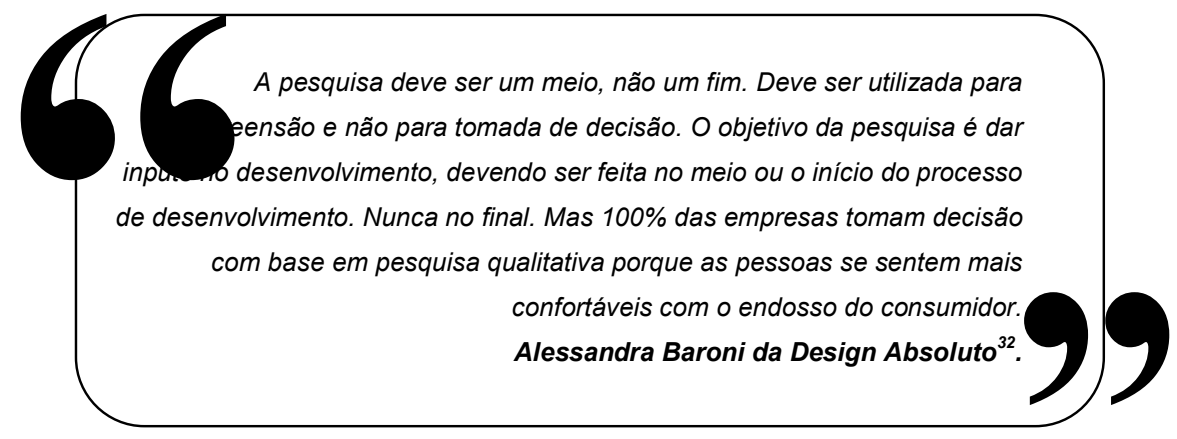

Pesquisas tradicionais de levantamento de dados e opiniões junto a consumidores como os focus groups ou estudos quantitativos, não são indicadas como ferramenta definitiva na avaliação de um novo design de embalagem porque (LOJACONO; ZACCAI, 2004, pg.98-127):

\footnotetext{
32 Informações concedidas à autora através de entrevista realizada em São Paulo, entre os meses de agosto e novembro de 2007, cujo conteúdo integral encontra-se na seção Anexos dessa dissertação.
} 
- Podem não vislumbrar necessidades e desejos inconscientes, fornecendo informações inadequadas que tendem a resultar na rejeição de novos rumos criativos;

- Podem gerar vieses nos resultados no caso de soluções inovadoras, visto que essas geralmente causam estranheza por não fazerem parte da rotina das pessoas, gerando ruídos em sua área de conforto;

- Os consumidores normalmente têm dificuldade de expressar seus sentimentos em relação a determinado objeto de estudo e a pesquisa pode ficar em uma esfera muito superficial de avaliação :gosto, não gosto, legal, bonito;

- Discussões em grupo tendem a influenciar a opinião individual, criando vieses nos resultados;

- As pessoas precisam de tempo para se envolver e avaliar o objeto de estudo - a convivência pode alterar completamente sua percepção;

- As pesquisas devem ser usadas para entender o que está por trás da reação do consumidor quanto ao objeto pesquisado, e não para fazer mudanças diretas ou correções na embalagem. Devem estar focadas na compreensão dos comportamentos e sentimentos inconscientes dos consumidores, logo, das necessidades e dos desejos não expressos verbalmente pelos clientes, para depois criar e testar novas formas de atendê-los. 


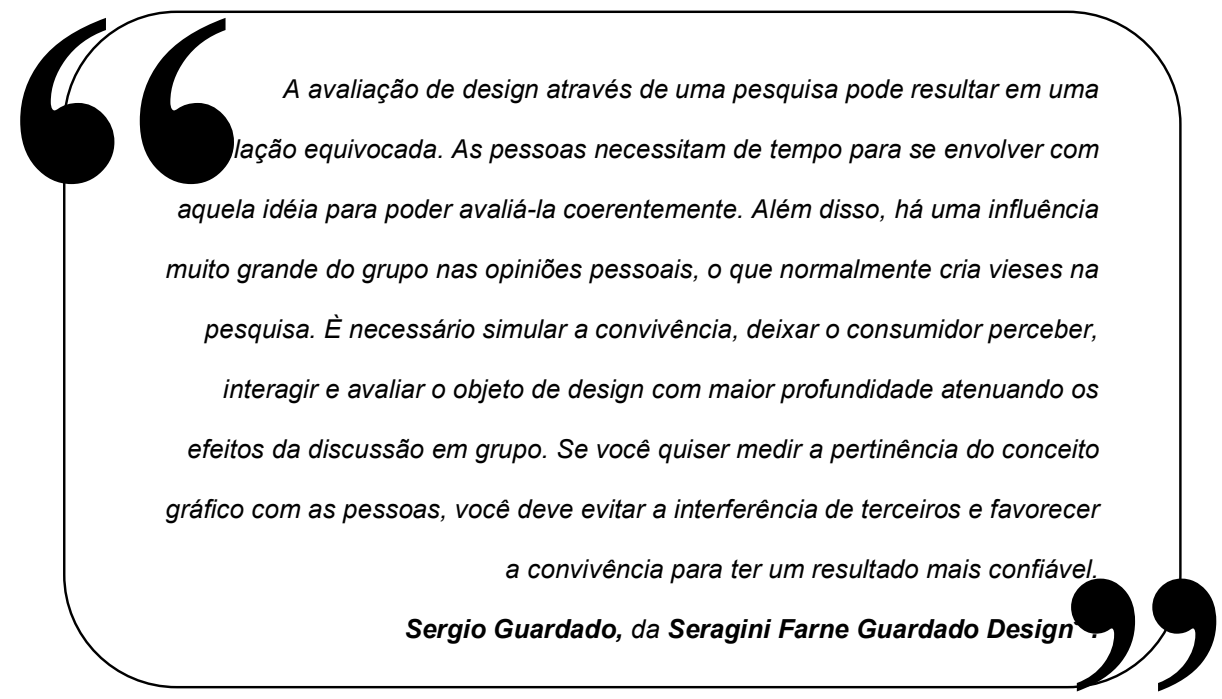

Assim, a pesquisa é uma grande aliada no desenvolvimento de embalagens quando utilizada com a finalidade de compreender o universo da marca e do consumidor, gerando idéias que irão alimentar o processo, ou como ferramenta de validação ou refinamento de conceitos criativos. Porém, sua utilização para aprovação de um determinado design deve evitada.

Adicionalmente, por constituir um recurso caro e complexo, muitas empresas acabam abrindo mão de seu uso. Nesse contexto, como reduzir as subjetividades na avaliação do design da embalagem pela equipe de marketing, para desempenhar uma análise mais consistente e coerente?

Para que o design de embalagens seja efetivo ${ }^{34}$ no processo de comunicação é imprescindível avaliá-lo a partir de critérios vinculados aos objetivos, às premissas e às especificidades estabelecidas no brief de embalagens. Ao considerar essas questões, as subjetividades são reduzidas, fazendo do processo avaliativo algo mais concreto e

\footnotetext{
33 Informações concedidas à autora através de entrevista realizada em São Paulo, entre os meses de agosto e novembro de 2007, cujo conteúdo integral encontra-se na seção Anexos dessa dissertação.

${ }^{34}$ Efetividade de emissão no processo comunicativo
} 
sustentado.

Para tanto, o responsável pela aprovação do projeto de design do ponto de vista mercadológico, seja este um gerente de produto ou um executivo de marketing, deve ter sido responsável ou, ao menos, parte integrante de todo o processo de briefing, garantindo o foco, objetividade e alinhamento na fase de aprovação da nova embalagem.

A avaliação do design deve ser realizada em função da resposta, ou não, aos objetivos previamente estabelecidos. Pouco importa se o produto de design tem uma composição de cores sofisticadas e estilo contemporâneo, se o objetivo inicial era posicionar a marca como uma opção de valor e atrair a atenção do público de classe sócio-econômica C.

Ao avaliar o design de embalagem é importante verificar como cada elemento formal, seja esse verbal ou gráfico, se relaciona com as questões abordadas no brief. Tal procedimento não constitui uma tarefa fácil, mas certamente trará uma maior racionalidade e solidez no julgamento.

Dado que não foram encontrados, até o presente momento, literaturas ou produções científicas que recomendem uma metodologia para avaliação do design de embalagem trazemos, adicionalmente ao aos objetivos traçados para essa dissertação, uma proposta de roteiro para análise, baseada na obra de Charles Morris (1985) sobre a questão da representação dos signos e do processo de significação, ou semiose.

Esse roteiro de avaliação é fruto de todo o aprendizado obtido durante a pesquisa para a dissertação e constitui um instrumento qualitativo de avaliação, sendo necessários maiores aprofundamentos e estudos para torná-lo em uma ferramenta quantitativa e, portanto, mais efetiva. Sua pretensão, portanto, está centrada em servir de guia aos profissionais envolvidos na dinâmica do design de embalagens; busca compartimentar e priorizar a análise do design de embalagens em 
relação às dimensões sintáticas, semânticas e pragmáticas do signo, defendidas por Morris (1985), com a finalidade de reduzir as subjetividades no processo de avaliação, reforçando o caráter estratégico do design.

A dimensão sintática abrange as qualidades materiais do signo em seu jeito particular de existir: forma, cor, textura, magnitude, intensidade, movimento, ritmo... A dimensão semântica abrange o signo em relação ao objeto que denota e a dimensão pragmática, as condições de interpretação ou compreensão da designação do signo. (SOUZA, 1992, pg. 68-83).

Aplicadas aos signos gráficos, cada uma dessas três dimensões se relacionam às seguintes questões-chave:

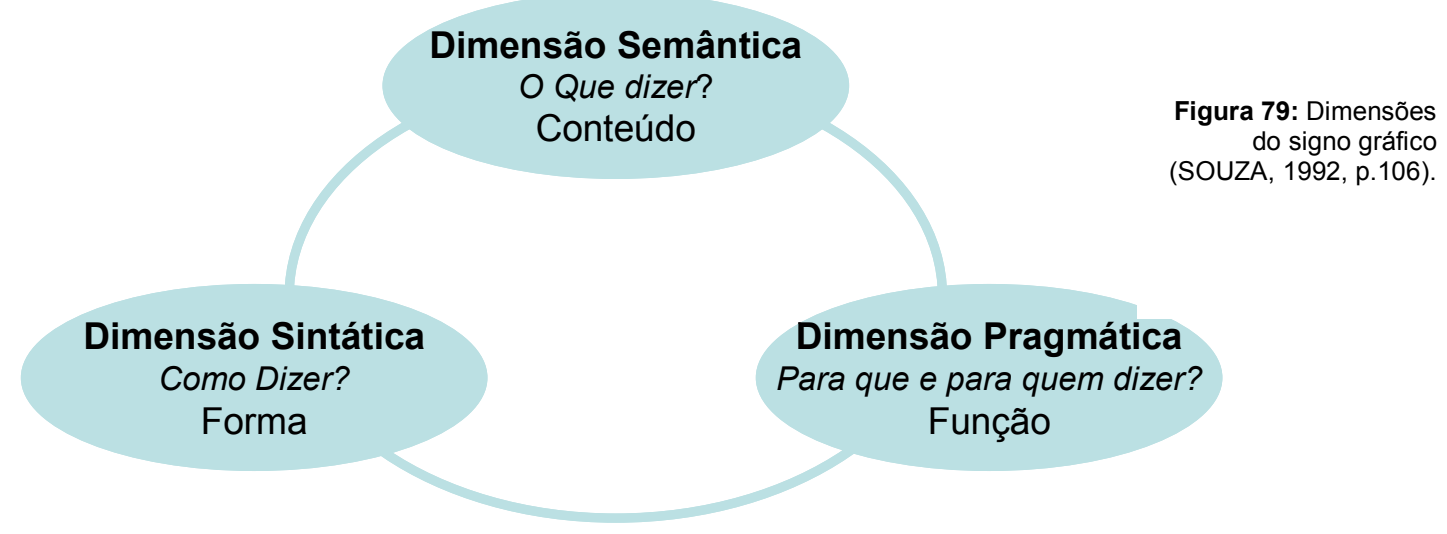

Ao relacionar essas três dimensões à embalagem, que também constitui um signo gráfico em essência, temos a correspondência com os seguintes aspectos:

- O ponto de vista semântico: relacionado aos elementos e temas visuais da embalagem que comunicam os valores, a essência, a personalidade, a identidade da marca e que a posicionam na mente do consumidor;

- O ponto de vista pragmático: relacionado às funções de 
comunicação e de uso da embalagem, compreendendo tanto os aspectos estruturais quanto gráficos, influenciando fortemente a percepção de qualidade da marca;

- O ponto de vista sintático: relacionado à estética da embalagem e como essa se destaca e se diferencia, bem como envolve e sensibiliza o consumidor no momento da compra. (sua forma, suas cores, texturas, tamanhos...).

As dimensões semântica e pragmática constituem aqueles fatores de avaliação diretamente relacionados ao brief, que respondem ao brief e que claramente carregam as informações ali prestadas, propiciando uma análise mais objetiva. Já a dimensão sintática se subordina às demais à medida que formai o suporte visual de significação utilizado para expressar as mais variadas finalidades de comunicação e altamente dependente de um conhecimento técnico, concentrado nas mãos do designer.

Figura 80: Sugestão de roteiro para avaliação do design de embalagens

\section{Roteiro esquematizado para avaliação do design da embalagem}

\begin{tabular}{|c|c|c|c|c|}
\hline \multirow{5}{*}{ Dimensão Semântica } & \multirow{5}{*}{$\begin{array}{l}\text { Marca } \\
\text { Conteudo }\end{array}$} & \multirow{4}{*}{ Posicionamento } & Temas Visuais & \begin{tabular}{|l} 
identidade de marca \\
personalidade de marca \\
valores de marca
\end{tabular} \\
\hline & & & Promessa & \begin{tabular}{|l|} 
Funcional \\
Social \\
Afetiva \\
Sensorial \\
\end{tabular} \\
\hline & & & Público Alvo & $\begin{array}{l}\text { qualificação (life style) } \\
\text { identificação (relevãncia, envolvimento) }\end{array}$ \\
\hline & & & \multicolumn{2}{|c|}{$\begin{array}{l}\text { Percepção de valor } \\
\text { (preço x valor) }\end{array}$} \\
\hline & & Conceito & \multicolumn{2}{|c|}{$\begin{array}{l}\text { Mensagem principal } \\
\text { Mensagem secundária } \\
\text { Informações complementares }\end{array}$} \\
\hline \multirow{3}{*}{ Dimensão Pragmática } & \multirow{3}{*}{$\begin{array}{l}\text { Consumidor } \\
\text { Função }\end{array}$} & $\begin{array}{l}\text { Reconhecimento } \\
\text { da marca }\end{array}$ & \multicolumn{2}{|c|}{$\begin{array}{l}\text { identificação/visibilidade } \\
\text { (grafico e estrutural) }\end{array}$} \\
\hline & & Qualidade de uso & \multicolumn{2}{|c|}{\begin{tabular}{|l|} 
Manuseio \\
Abertura/Fechamento \\
Desempenho \\
Armazenamento \\
Descarte \\
\end{tabular}} \\
\hline & & Indicações de Uso & \multicolumn{2}{|c|}{\begin{tabular}{|l} 
Instruções de uso (gráfico) \\
Sinalizações de uso (estrutural)
\end{tabular}} \\
\hline Dimensão Sintática & $\begin{array}{l}\text { Linguagem } \\
\text { Forma }\end{array}$ & Variáveis visuais** & \multicolumn{2}{|l|}{\begin{tabular}{|l|} 
formatos \\
cores \\
tons \\
texturas \\
orientação \\
tamanhos
\end{tabular}} \\
\hline Objetivos & \multicolumn{4}{|l|}{$\begin{array}{l}\text { marketing } \\
\text { comunicação }\end{array}$} \\
\hline
\end{tabular}


Do ponto de vista semântico, é importante avaliar se o design proposto responde ao posicionamento estabelecido para a marca e se as mensagens transmitidas se alinham ao conceito do produto. Alguns questionamentos para reflexão seriam:

- $\quad$ Temas: quais os temas visuais trazidos pelo design? Como eles se concectam à identidade, à personalidade e aos valores da marca descritos no brief?

- Promessa: a promessa da marca está clara? Que tipos de promessa são percebidas? Como a promessa percebida através do design se destaca perante a concorrência? A priorização de atributos e benefícios cria valor e diferenciação para o produto? A representação da promessa está alinhada à marca? É exagerada? É crível?

- Público alvo: O design remete ao estilo de vida do usuário? Possui elementos que criam identificação com o imaginário do público alvo? Possui mensagens relevantes, específicas para esse público que geram envolvimento?

- Percepção de valor: o produto parece caro? Barato? Denota qualidade? Como se posiciona frente à concorrência?

- Conceito: quais as mensagens transmitidas? Como se relacionam com o brief? As mensagens são fortes o suficiente para persuadir o usuário à compra?

Do ponto de vista pragmático, é importante avaliar se o design proposto favorece as funções de comunicação e de uso da embalagem, quando da interação com o consumidor:

- Reconhecimento da marca: o design propicia que a marca seja facilmente identificada pelo consumidor? É visível? A arquitetura de identificação do produto em uma linha de produtos é clara?

- Qualidade de uso: a embalagem é fácil de ser manuseada? 
Possibilita o fácil acesso ao produto? É fácil de ser armazenada? Descartada? Sua abertura e fechamento são claros?

- Indicações de uso: existem instruções de uso de produto? São claras? Facilitam o uso do produto? A estrutura física da embalagem proporciona entendimento de uso/manuseio? É instintivas ou alusivas (exemplo ranhuras ou texturas na superfície denotando a área de pega)?

Na dimensão sintática, a embalagem deve ser avaliada do ponto de vista formal, constitutivo. A dimensão sintática proporciona destaque e diferenciação estéticos, bem como sensibiliza o consumidor no momento da compra através de suas variáveis visuais. Essa dimensão é a mais difícil de ser julgada, visto que pode representar coisas diferentes para o usuário, variando de acordo com seu repertório simbólico, o que implica em subjetividade. Assim, a dimensão sintática deve ser, preferencialmente, suportada e justificada pelo designer, em função das técnicas de manipulação estética ou verificada junto ao público alvo, através de pesquisa.

É importante, contudo, atentar para os objetivos estabelecidos no brief e se a solução apresentada responde aos objetivos de marketing e de comunicação. Embora a avaliação real da efetividade da embalagem só possa ser mensurada a partir dos resultados obtidos em termos de incremento de participação de mercado, vendas, imagem de marca, redução de custo do produto, inovação, $\mathrm{ROI}^{35}$ e premiações (MOZOTA, p.195-196), a decisão de implementar ou não um determinado design deve considerar a probabilidade deste design responder a estes objetivos.

${ }^{35}$ ROI do Inglês Return on investment ou Retorno sobre o investimento 
Após a etapa de Avaliação do design, o executivo de marketing deve solicitar à agência de design as revisões necessárias até que a embalagem seja definitivamente aprovada. Se possível, a embalagem deve ser submetida à pesquisa junto ao consumidor para verificar se existem pontos negativos e se a recepção das mensagens se alinham às finalidades de comunicação pretendidas.

Paralelamente a essa fase de validação com o consumidor, deverão ser realizados os testes de validação técnica da proposta, ainda na forma de protótipos. Estando a embalagem aprovada sob ambos os aspectos - de consumo e técnico, deve iniciar-se o processo de viabilização produtiva e econômica da embalagem, liderado pelas áreas de P\&D e cadeia de suprimentos, culminando da implantação do novo design.

Assim, a embalagem deve estar inserida dentro do planejamento da marca e ser gerenciada livre de subjetivismos, com base em uma abordagem projetual associada às atividades de marketing e de marca, dentro de uma função ampliada do design, aonde a responsabilidade por seu desenvolvimento não se restringe às atividades de criação do designer, mas a uma única atividade que começa e termina no marketing, e cuja ferramenta essencial, da qual dependerá a qualidade da solução de design, é o brief.

Mas como relacionar as recomendações teóricas às praticas de mercado? Através de pesquisa junto aos profissionais da área, foi possível avaliar melhor o quadro atual do design de embalagens no Brasil, tema abordado no capítulo IV dessa dissertação. 


\section{Capítulo 4}

Realidades na Gestão estratégica do design de embalagens

De acordo com a pesquisa realizada com profissionais e especialistas diretamente envolvidos no design de embalagens, cujo detalhamento será abordado a seguir, é possível verificar que, ao mesmo tempo em que o mercado vem percebendo a importância do design de embalagens como ferramenta de comunicação de marca e como elemento motivador de compra, poucas são as empresas que vêm gerenciando com propriedade essa importante expressão marcária, maximizando seu potencial comunicativo e funcional a favor da empresa e do consumidor.

O processo de gestão, como um todo, detém inúmeras oportunidades de melhoria, uma vez que ainda favorece opiniões e critérios subjetivos de avaliação, bem como uma dinâmica desordenada, pouco focada e sistematizada, com algumas poucas exceções restritas às companhias multinacionais.

Assim, gerir o design de embalagens a partir de uma visão estratégica, alinhada ao planejamento de marca e voltada para uma função ampliada do design, que não se resume às questões estéticas, mas ao design como processo organizador de informações que se materializam no substrato visual da embalagem, constitui uma imensa oportunidade e um grande desafio para todos os profissionais envolvidos nesse processo.

\section{1 - Pesquisa: Metodologia}

A pesquisa foi realizada através de um estudo exploratório, buscando ampliar o conhecimento existente sobre o tema, visto que é 
uma área pouco estudada em termos mercadológicos. Para tanto, foram realizadas entrevistas em profundidade com profissionais envolvidos no processo de design de embalagens - designers e executivos de marketing, de modo a apontar as principais práticas, dificuldades e oportunidades encontradas nas relações atualmente existentes.

Foram selecionados profissionais com base na experiência e vivência do tema, tanto de agências de design quanto de empresas de consumo, sendo realizadas, no total, seis entrevistas em profundidade, entre os meses de agosto e novembro de 2007 :

- Design Absoluto: Alessandra Baroni, sócia-diretora, responsável pela área de planejamento. Agência de design especializada em design de embalagens, tendo como clientes grandes empresas multinacionais de consumo como Unilever, Danone, Hersheys e Reckitt Benckiser.

- Design com Z: Zeuner Fraissat sócio-diretor e designer. Agência de design especializada em identidade de marca, sendo responsável pela gestão de identidade visual e design de embalagens da Natura;

- Seragini Farne Guardado Design: Sergio Guardado, sóciodiretor, responsável pela área de pesquisa de design. A Seragini Farne Guardado é uma das maiores e mais antigas agências de design brasileiras e entre seus clientes estão Sucos Del Valle, Ypê, Perdigão, Dona Benta;

- Rex Design: Gustavo Piqueira, sócio-diretor e designer. Agência de design especializada em design de embalagens, tendo como clientes grandes empresas multinacionais de consumo como Unilever, Paulista, Danone, Kraft Foods;

- Ricardo Arantes, gerente global de inovação para a categoria de cuidados com o lar da Unilever. 


\section{2 - Módulos e questionamentos levantados}

A fim de tentar traçar uma visão geral junto aos entrevistados, foi desenvolvido um roteiro baseado em quatro pilares que englobam as principais nuances da temática - design de embalagens e comunicação de marca, abordadas na parte teórica desta dissertação, com um maior enfoque na questão da metodologia de desenvolvimento e avaliação do design de embalagens.

\section{1) Design de embalagens - importância e objetivos:}

Você considera a embalagem uma ferramenta estratégica?

Você acha que as empresas se utilizam integralmente do potencial comunicativo da embalagem, gerenciando com propriedade esse elemento de identidade de marca?

\section{2) Design de embalagens: metodologia de desenvolvimento:}

Existe, na sua empresa, um método projetual definido para o design de embalagens?

\section{3) Design de embalagens: critérios e processos de avaliação:}

Como se avalia o design de uma embalagem? Que critérios são levados em consideração?

Quem julga o design de embalagens? Deve-se validar o design desenvolvido através de pesquisas com o consumidor?

\section{4) Design de embalagens: potencialidades e futuro}

Quais os principais desafios para o Design de embalagens e tendências futuras? 
Na seqüência serão apresentadas as opiniões dos profissionais entrevistados. A estrutura de apresentação consiste na pergunta realizada ao entrevistado, seguida de uma conclusão geral das opiniões expressas por todos os especialistas consultados e, na seqüência, a transcrição resumida ${ }^{36}$ das respostas de cada um dos envolvidos.

\section{3 - Resultado da entrevistas realizadas junto à profissionais envolvidos no design de embalagens}

a) Você considera a embalagem uma ferramenta estratégica?

\section{Conclusões gerais}

Todos os entrevistados concordam que a embalagem é uma ferramenta estratégica da marca porque contribui diretamente na construção de imagem de marca, na diferenciação no ponto de venda, bem como na percepção que os consumidores têm dos produtos. Além disso, constitui uma ferramenta inevitável de comunicação da marca nem sempre uma marca pode contar com propaganda e promoção, mas a embalagem sempre estará no ponto de venda para persuadir o consumidor.

\section{Alessandra Baroni}

A embalagem é uma ferramenta estratégica e esse entendimento deve aumentar. Afinal, não existe mais televisão sem controle remoto, as pessoas não querem mais ver comerciais, outdoor é sinônimo de poluição visual e a decisão de compra cada vez mais é feita no ponto de venda. Ou a embalagem fala naquela hora, ou ela não vai falar mais. Ou você impacta o consumidor naquele exato momento, que

\footnotetext{
${ }^{36} \mathrm{Na}$ seção Anexos, encontra-se a transcrição integral das entrevistas realizadas.
} 
dependendo da categoria pode tomar alguns segundos, ou não vai adiantar nada a marca está bem posicionada, ou você querer comunicar algo a mais. Esse é o caráter estratégico da embalagem. Você pode perder vendas por causa dela, ou ganhar.

\section{Ricardo Arantes}

A embalagem é uma ferramenta estratégica porque consegue transmitir os valores da marca e gerar diferenciação no ponto de venda, onde, para a categoria de produtos de limpeza, acontecem as principais decisões. Trata-se de uma forte ferramenta de diferenciação e conquista do consumidor, visto que transmite os principais elementos de satisfação do produto, seus atributos e benefícios, auxiliando na tarefa de posicionamento da oferta. Além disso, contribui para o negócio tanto estrategicamente, ajudando na construção do Equity da marca, quanto no curto prazo, auxiliando nas vendas.

\section{Sergio Guardado}

Em muitos produtos a embalagem é a cara da marca. Se considerar o sabão em pó, a embalagem aparece mais que o próprio produto! Certos produtos são mais conhecidos pela embalagem do que pela própria essência física do produto. Seguramente a embalagem é, para muitos produtos, o grande formador da própria essência da marca. Ou seja, a construção da identidade das coisas se dá muito pela sua embalagem, principalmente, produtos de consumo de supermercado. Talvez uma bicicleta não dependa muito da embalagem, mas produtos de consumo de supermercado, sem dúvida, são identificados pela embalagem, ou seja, o primeiro território privilegiado de percepção e construção de personalidade de marca é a embalagem, mais do que a propaganda ou outras ferramentas, que nem todos os produtos têm. Nem todo produto tem propaganda: embalagem, no mínimo, o produto 
tem. Nem todos os produtos têm comunicação, nem todos têm promoção, nem todos usam largamente essas ferramentas de marketing, em resumo, a embalagem sempre estará lá. Daí ser valor estratégico.

\section{Zeuner Fraissat}

A embalagem é um ponto de contato importante para construir uma identidade de marca, não só uma identidade visual, identidade enquanto personalidade; um ponto de contato extremamente importante para levar as mensagens da marca, especialmente as que não têm mídia. Não que a embalagem consiga dizer tudo, mas ela tem que ser um parágrafo de um texto de marca formado por várias outras coisas. A marca deveria falar com o consumidor em três parágrafos: a embalagem, a mídia de massa e o relacionamento. $O$ design de embalagens, entretanto, ainda está muito centrado na comunicação dos benefícios, das habilidades do produto e em responder à briefs que pedem para "saltar da gôndola", para destacar a marca - a cultura dos splashes, extremamente americana. Acho que as pessoas cada vez mais vão se importar menos com os números de opções de produto na gôndola e mais com a marca, no sentido de quem está por traz da marca, o que essa marca pensa, o que ela tem de afinidade comigo, o que ela vende além do beneficio dos produtos. E a embalagem é extremamente importante para agregar este tipo de mensagem à marca, a embalagem é um dos elementos mais importantes na construção de um pensamento sobre a marca.

\section{Gustavo Piqueira}

A embalagem é uma ferramenta estratégica, afinal detém uma função na identidade primeira do objeto, porque por mais que você tenha uma campanha, por mais que você tenha outras estratégias de 
comunicação, a embalagem é o meio de comunicação inevitável. Ela pode até não ser a peça mais importante no seu plano de comunicação, mas ela é inevitável. Se você erra num filme, você pode torcer para que metade do público não assista, se você erra na embalagem, todos vêem.

b) Você acha que as empresas se utilizam integralmente do potencial comunicativo da embalagem, gerenciando com propriedade esse elemento de identidade de marca?

\section{Conclusões gerais:}

As empresas ainda estão se conscientizando da importância estratégica dessa mídia da marca. Hoje, os profissionais têm mais clara a sua importância, entretanto, a maneira que gerenciam o design de embalagens ainda demonstra que há grandes oportunidades para melhorias: muitas empresas consideram a embalagem como um custo adicional, não buscando desenvolver habilidades técnicas que promovam sua correta gestão; outras ainda optam por copiar a marca líder ao invés de criar valor para o consumidor e competitividade no mercado através de embalagens inovadoras; há aquelas que subutilizam o trabalho do designer, bem como as que delegam ao consumidor a responsabilidade de avaliação e aprovação de novos projetos, usando os resultados de pesquisa como justificativa à falta de preparo técnico. O potencial comunicativo das embalagens ainda é subutilizado e mal gerenciado e, portanto, pouco potencializado.

\section{Alessandra Baroni}

A embalagem desempenha algumas funções: a primeira é o impacto, porque sem ele você não consegue comunicar nada. A segunda é a mensagem que se quer transmitir, momento em que você 
vai fazer o consumidor se interessar ou não por aquilo que você está comunicando. A terceira é o Branding, porque se isso não reverter para a marca, você não adicionou valor e também não cumpriu o objetivo total da comunicação. Através da embalagem se comunica tudo, benefício funcional, valores emocionais, o posicionamento da marca, a personalidade: você comunica a própria marca, mesmo através de um design estrutural. Com a embalagem você constrói o Equity da marca em todos os sentidos, funcionais e emocionais. Mas todo esse potencial comunicativo ainda não está claro para todas as empresas. Afinal, existem muitos profissionais julgando um design pelo o que elas gostam ou o que elas não gostam. Muitas vezes os profissionais esquecem pra quem que elas estão trabalhando - o consumidor.

\section{Ricardo Arantes}

A embalagem é uma mídia visto que interage com o consumidor, transmitindo informações e mensagens. Embora a embalagem ainda não tenha alcançado o destaque que mereça dentro das organizações e, conseqüentemente, no mix de marketing e no mix de meios de comunicação, a tendência é que a embalagem ganhe cada vez mais espaço. Hoje a similaridade entre marcas e produtos é muito grande e a decisão de compra se faz cada vez mais no ponto de venda, onde a embalagem é o meio mais eficaz de gerar diferenciação para o consumidor. É, nesse sentido também, que o design ganha importância, promovendo diferenciação e visibilidade para a marca.

A maioria das empresas exploram muito pouco esta importante ferramenta da marca. O trabalho acaba sendo muito limitado, já que é visto como um custo adicional. Em outros mercados, como na Europa e no Japão, o potencial comunicativo da embalagem é amplamente explorado, configurando uma mentalidade muito mais desenvolvida. Algumas empresas até têm consciência da importância da embalagem 
na comunicação de marca, mas ainda têm uma visão extremamente voltada para custos e lucratividade no curto prazo. Isso acontece porque partem de uma cultura, de uma visão estritamente "financeira" do negócio, e não uma visão de marca, uma visão holística do consumidor. Logo, não possuem e não buscam desenvolver habilidades técnicas para o gerenciamento do design de embalagens, visto que não é foco de atenção. Poucas são as empresas que empregam designers, e, quando sim, o foco de suas atividades e ações está mais concentrado nas atribuições de resistência e proteção da embalagem. Para um gerenciamento ideal, deveriam ser criados times multifuncionais com profissionais de Design e Marketing liderando o tema - isso certamente faria toda a diferença.

\section{Sergio Guardado}

As empresas cada vez mais estão se convencendo da importância estratégica da embalagem. A Seragini existe há 26 anos, e se compararmos os anos 80 com os dias atuais, vamos ver que tudo era muito diferente. Existia uma idéia da embalagem como uma espécie de adereço cosmético e inútil, uma certa visão puramente estética, de um complemento decorativo e secundário, supérfluo. Hoje qualquer profissional de marketing sabe que se a embalagem dele for ruim, a chance dele vender menos é muito alta. Hoje é voz corrente que se você não prestar atenção na embalagem, você perde dinheiro. Mas ainda é possível melhorar muita coisa. Consciência da importância já existe, o que ainda não existe é instrumentação inteligente desta consciência.

No Brasil, existe a idéia de que se o líder construiu uma certa notoriedade em função de alguns sinais gráficos, todo mundo, bem ou mal, necessita usurpar um pouco dessa propriedade que a marca original criou. Isso é um equívoco muito grande e o potencial 
comunicativo da embalagem acaba sendo subutilizado. Acho que falta ainda uma postura mais empreendedorista. Acho ainda que falta, nas empresas, a ousadia de entender que, se uma marca se estabeleceu com uma certa linguagem, você pode buscar outros temas relativos àquele produto, outras facetas do imaginário ligado a aquele produto. Alguém colocou pudim de leite condensado na embalagem de leite condensado e todos repetem a mesma fórmula. Deve ter alguma outra utilização para esse produto que ainda não foi explorada! Ou seja, existe uma certa mediocridade de todo mundo querer ser mediano, de todo mundo querer ser meio previsível para que não seja preciso arriscar, e o mercado acaba se "comoditizando".

\section{Zeuner Fraissat}

As empresas ainda estão numa cultura muito de olhar para o mercado e não à procura de inovações alinhadas com sua própria gênesis. A embalagem potencializa a comunicação quando faz parte de um todo que coincide na transmissão de um pensamento de marca. Daí sim ela convence as pessoas, porque vai além do produto, porque comunica a causa da marca, como a Natura. Não adianta só uma embalagem bonita, encantadora. Você pode até ser convencido a comprar, a experimentar, mas você só vai ficar com esse produto se ele funcionar, se entregar o que prometeu - seja uma ação, um beneficio claro ou uma causa. A embalagem é importante pois encanta e motiva a compra, mas não é suficiente para fazer os consumidores permanecerem na marca, afinal, eles estão cada vez mais atrás de questões como mercados justos, biodiversidade, ecologia, de modo que a embalagem deve ser parte do programa da marca.

Eu acho que ela tem coisas básicas que o consumidor já está se importando, como o consumo, o próprio de material e que as empresas deveriam atentar: o quanto essa embalagem tem de plástico, tem de 
papel demais, se isso é demais, se não podia ser menor... Então, o designer e as empresas devem se preocupar com isso, redução do material, redução do impacto ambiental dessa embalagem. Outro ponto importante é que as embalagens devem, mais do que "gritar" no ponto de venda, chamar as pessoas para perto, instigar, convidar para uma interação. Eu acho que as pessoas gostariam de ser menos bombardeadas pelas embalagens, menos açoitadas quando vão fazer compras - as embalagens e as marcas deviam cuidar para que os consumidores queiram chegar perto delas e tirá-las da gôndola, deviam cativar o consumidor a conhecer o produto.

\section{Gustavo Piqueira}

A noção da embalagem como um elemento estratégico e não como material de ponto de venda é algo que ainda está surgindo, se consolidando.

Reconheço que melhorou muito, tanto é que surgiram dezenas de empresas de design de embalagens, mas ainda tem muita empresa que o trabalho é ruim, o que é sinal de que a questão de embalagem ainda não está super amadurecida. Existe um nível de competência e não excelência.

Ainda existem muitos vícios como os códigos de categoria, que ninguém sabe onde e porque começou, mas é uma mecânica usual você é obrigado a fazer mesmo sem saber exatamente se isso é algo relevante para o consumidor.

Para um creme dental, por exemplo, um clássico de categoria, sempre se utiliza a mesma diagramação: divide-se a embalagem em três, os dois terços da esquerda vão para o logo, e o terço que sobra na direita para o benefício, sabor, etc. Todos têm a mesma estrutura, mas não acredito que a base disso seja algo inerente ao consumidor; imagino que foi se estabelecendo a partir da marca líder, que foi ditando 
o comportamento dos concorrentes, e fazendo o consumidor se acostumar até chegar a um ponto que isso não mudou mais, virando uma verdade natural, originando os vícios de cada categoria.

Quanto maior a estrutura de uma empresa, maiores são os vícios. Infelizmente, vejo que em muitos projetos que faço, os resultados acabam se diluindo nos códigos de categoria, virando quase um design genérico.

Outro vício é envolver o designer somente em algumas etapas do projeto. Em alguns, o envolvimento inicia antes da solução gráfica em geral estes saem melhor - em outros, o envolvimento inicia-se apenas no final, como uma espécie de decorador, nestes é mais fácil que as coisas se diluam.

E ainda há o vício da pesquisa. A atuação do designer fica limitada, muito em razão das pesquisas, pois, em muitos casos, a pesquisa é "tomada ao pé da letra": se saiu na pesquisa é porque o consumidor quer.

c) Existe, na sua empresa, um método projetual definido para o design de embalagens?

\section{Conclusões Gerais}

De modo geral o brief é desenvolvido pela área de marketing (com o suporte das áreas de P\&D, engenharia, etc). Após receber o brief, as agências de design aprofundam as informações recebidas através do brief e mediante pesquisas sobre o consumidor, sobre o mercado, sobre a concorrência, de modo a encontrar um tema criativo que alimente o time de criação, ou seja, os designers. Uma vez desenvolvidas as embalagens, que em uma primeira etapa constituem conceitos criativos, apresenta-se para o cliente. O conceito escolhido pelo cliente será detalhado, refinado graficamente e após nova 
submissão, se aprovado, será finalizado.

\section{Alessandra Baroni}

A metodologia é a seguinte: recebemos o brief do cliente. A área de planejamento pesquisa tendências, competidores, outras categorias, até encontrar um ou mais temas para a criação. A partir disso criamos alguns conceitos de comunicação. Discutimos os conceitos com a área de criação que começa a trabalhar no desenvolvimento. Além disso, acreditamos que deve haver uma informação privilegiada na embalagem, de modo que seja mais fácil para o consumidor compreender a mensagem. Então, criamos três embalagens dentro do mesmo tema que comuniquem, por exemplo, três diferentes mensagens e apresentamos para o cliente.

\section{Ricardo Arantes}

Hoje não há um processo definido, mas estamos trabalhando para isso. $\mathrm{O}$ time de Marketing desenvolve o brief juntamente com a área técnica de P\&D e Embalagens, responsável pelas questões de viabilidade, e apresenta para a agência de design de embalagem.

\section{Sergio Guardado}

O primeiro passo é entender o brief que o cliente apresentou e isso envolve pesquisa e planejamento. Então traçamos um mapa de onde estamos e aonde pretendemos chegar. A primeira ação concreta é o trabalho de pesquisa que pode envolver uma relação direta com o consumidor, uma discussão em grupo, uma pesquisa na Internet, uma entrevista por telefone, visitar o ponto de venda, avaliar a concorrência, até a criação de uma primeira plataforma estratégica. A partir daí, iniciase um processo de brainstorming, seguido da criação de conceitos que vão para as mãos de um ou mais designers. Ao desenvolver as 
primeiras embalagens, realizamos um check-list estratégico para avaliar se o design responde às necessidades mercadológicas apresentadas no brief e um check-list técnico, para ver se o design é viável. Se o design for internamente aprovado, montamos uma apresentação detalhando todo o processo de desenvolvimento. Depois da apresentação, segue o processo de refinamento conceitual e estético e a etapa de finalização.

\section{Zeuner Fraissat}

Todo designer tem seu momento criativo, introspectivo, aonde tem que mergulhar nas informações e nas suas experiências para descobrir quais são as respostas. Depois deve haver pontos de diálogos com o cliente; não a apresentação da embalagem, mas sim um primeiro diálogo, um segundo diálogo... e, então, à medida que o design vai se materializando a gente ajusta o brief de modo a ter um alinhamento de expectativas entre ambas as partes, até chegar em uma solução que seja ideal para a marca.

\section{Gustavo Piqueira}

Você tem que ter métodos criativos diferentes para cada projeto. Para definição do método é necessário ter um estudo do entorno: avaliar o público, a concorrência e o ambiente, e priorizar com diferentes pesos. Isso porque cada projeto tem seus elementos-chave, suas variáveis, como o público, o produto, o objeto, aonde ele vai aparecer, quem são os competidores, e como se relacionam com esse produto ou marca.

d) Qual a importância do brief no design de embalagens? Existe um formato Ideal? Quem está envolvido no processo?

\section{Conclusões gerais:}

O brief é o documento que norteia todo o processo de design de 
uma nova embalagem - a qualidade do resultado do design está intimamente ligada à qualidade do brief. Mas o brief deve ir além de um simples documento em papel: deve ser fonte de informações relevantes ao desenvolvimento, instrumento de inspiração e estímulo ao designer e base de profundo conhecimento sobre o público alvo. Deve, minimamente, constar no brief: panorama de mercado e da concorrência, informações sobre o público alvo, histórico da marca, posicionamento da marca, objetivos bem definidos.

\section{Alessandra Baroni}

O brief é que vai nortear o planejamento da marca e depois a criação. Ele é o documento com o qual confrontamos todas as artes. Ele tem que ter todas as informações relevantes à criação, bem como inspiração suficiente para colocar o cliente como top of mind na cabeça da agência. As informações não necessitam estar escritas - há marcas que nos levam à casa do consumidor, por exemplo, o que é extremamente inspirador e informativo. Ou seja, é importante ir além das palavras, passear no supermercado, discutir junto com o cliente para se obter bons resultados.

Entretanto, poucos são os profissionais que sabem da importância do brief no processo criativo. Os profissionais, especialmente os mais jovens, não têm nem experiência em desenvolvimento de embalagem e tratam a embalagem como um invólucro, e não como uma ferramenta de comunicação. É preciso profundidade, conhecimento para poder transmitir as informações de forma correta e inspiradora em um brief, bem como definir o que se quer comunicar através da embalagem. Além disso, é importante que o responsável pela aprovação esteja envolvido durante todo o processo, bem como na entrega dos trabalhos criativos, propiciando um maior alinhamento entre os envolvidos. 


\section{Ricardo Arantes}

O brief é de fundamental importância porque dá a direção para o resultado gráfico esperado. Tendo a dizer que a responsabilidade pelo resultado é dividida $50 \%$ em função da qualidade do brief e $50 \%$ em função da qualidade técnico-criativa do designer. $O$ formato ideal de brief seria: resumo sobre a marca, seus valores; resumo sobre o público alvo e o que este valoriza; atributos e benefícios do produto que a embalagem quer transmitir; objetivos. O brief deve ser desenvolvido por marketing com o suporte da área técnica de embalagens e da área interna de design, se houver. O importante é que as pessoas que estejam envolvidas no processo de briefing e, posteriormente, de criação, tenham um profundo conhecimento da marca, do consumidor, das implicâncias técnico-produtivas bem como um perfil criativo.

\section{Sergio Guardado}

Quando eu comecei a trabalhar, o brief era uma verdadeira divindade, diante do projeto do qual ele girava. Hoje, o cliente apresenta o produto, o problema e uma questão pra você resolver. O brief, nas empresas de ponta, é, hoje, um estímulo para um designer que detém uma postura muito mais estratégica e questionadora. Questionadora não no sentido de contrapor-se ao brief, mas no sentido de crescer, de colocar-se no lugar da verdadeira divindade que é o consumidor. Acho que atualmente há um deslocamento de uma soberania absoluta do cliente-brief, para uma negociação entre esses três atores: cliente, consumidor e designer. Isso porque o designer cresceu, deixando de ser um desenhista executador de serviços, para ser um interlocutor de branding.

Minimamente, o brief deveria estabelecer o que o cliente quer e porquê. E a partir disso é necessário avaliar com quem você quer falar, 
qual seu perfil, qual sua demanda simbólica, quais as principais dinâmicas da categoria desse produto, quais são as alternativas de consumo àquele produto e qual a história dessa marca. A rigor, quanto mais informação, melhor. Além disso, é importante também que sejam informados no brief os pré-requisitos técnicos que viabilizam o lançamento da embalagem.

\section{Zeuner Fraissat}

Ele tem que ser fruto de uma grande conversa. Eu não acredito no brief que vem pronto e a gente já leva a embalagem pronta. Não acho que a gente faz design sozinho. Me frustro muito quando fazemos um contrato e o cliente tem uma visão de que eu tenho que dar todas as respostas. O design é fruto do trabalho do cliente e do designer: precisamos nos reunir, conversar, nos aprofundar no universo dessa marca para que o trabalho valha à pena. $E$, uma vez que o cliente me contou tudo, me deu a sua contribuição, eu enquanto designer decodifico, entro na história de saber que temperatura tem isso, que cor tem isso, que signo é esse. Mas para isso é importante estabelecer um relacionamento, porque para mim só funciona se eu puder conhecer essa marca em profundidade. Por isso, quanto mais tempo durar esse relacionamento, melhor. Tem marca que a gente trabalha há mais de quatro anos e, por isso, vamos aprendendo a conhecer os defeitos, as virtudes, como em um casamento, só que usamos essa inteligência do relacionamento para as marcas.

\section{Gustavo Piqueira}

Um bom brief é um panorama geral do produto e do ambiente no qual este se insere: objetivos claros e bem definidos.

É muito comum encontrar nos briefs, como objetivo, ter impacto e tornar a marca mais moderna. Mas o que é ser moderno, afinal? 
Impacto também é algo muito associado à visibilidade no ponto de venda, quando deveria ser considerado em um sentido mais amplo, como chamar a atenção de alguém por algum motivo relevante, sem necessariamente ter que gritar. O impacto é um dos vícios dos briefs, ainda que a percepção do produto no ponto de venda seja algo importante.

Ou seja, muitos profissionais não sabem muito bem o que exatamente necessitam, não sabem o que pedir para o designer. Logo, é fundamental saber identificar quais são os dados relevantes para aquele projeto de design e saber transmiti-los ao designer. Não basta dizer que a embalagem tem que ter impacto ou outras obviedades.

DESIGN DE EMBALAGENS - CRITÉRIOS E PROCESSO DE AVALIAÇÃO

e) Como se avalia o design de uma embalagem? Que critérios são levados em consideração?

\section{Conclusões gerais}

Ainda hoje os critérios de avaliação de design são bastante subjetivos. Embora muitos profissionais busquem melhorar o processo de avaliação usando como base o brief e procurem se colocar no lugar do público alvo, as questões estéticas normalmente são avaliadas de acordo com o gosto pessoal do cliente.

\footnotetext{
Alessandra Baroni

O mais importante é que o cliente avalie o conceito criativo apresentado e escolha um dos conceitos para que a agência possa, a partir daí, determinar o detalhamento estético e técnico. O objetivo é ter, primeiramente, o conceito de comunicação aprovado junto ao cliente, e
} 
não a embalagem como um todo. Os critérios de avaliação devem estar relacionados ao brief e ao público alvo, centrando-se em questões conceituais e não em questões de linguagem: a linguagem deve estar a cargo da agência que entende tecnicamente de estética, de linguagem e comunicação gráfica. A agência é que deve recomendar qual a melhor forma de comunicar aquilo que o cliente aprovou como conceito de comunicação.

Além disso, os profissionais não podem esquecer, durante a avaliação, para quem eles estão trabalhando.

\section{Ricardo Arantes}

Para avaliar o design de embalagem, são levados em consideração os seguintes critérios: alinhamento com o brief, aspectos estéticos, aspectos técnicos e funcionais, entendimento do consumidor. Sempre que possível buscamos validar a embalagem com o consumidor, mas, durante o processo ou mesmo quando não é possível submetê-la ao público alvo, buscamos "enxergar" a embalagem do ponto de vista do consumidor para um melhor julgamento. A avaliação, entretanto, é muito subjetiva, uma questão intuitiva como a maioria das avaliações de conceito e comunicação de marca.

Já a validação é feita conjuntamente entre a área de marketing e de pesquisa e desenvolvimento, considerando os resultados de pesquisa junto ao consumidor.

\section{Sergio Guardado}

A avaliação de design ainda é muito irregular. Há profissionais que fazem avaliações estratégicas, assim como há profissionais que julgam baseados em critérios pessoais. As pessoas esquecem que aquela embalagem deve agradar ao consumidor, que normalmente tem um gosto específico, freqüenta lugares específicos e tem necessidades 
específicas, distintas das do cliente. Com honrosas exceções, normalmente o processo de avaliação é melhor nas grandes empresas, mas, de modo geral, trata-se de critérios subjetivos. O que temos feito para minimizar esse problema é referendar o projeto diretamente com o público alvo.

\section{Zeuner Fraissat}

Ser subjetivo não é um problema porque não quero me relacionar com máquinas. Só as máquinas não têm atitudes próprias, não têm pensamento, não têm gosto pessoal... Só não se pode confundir isso com "juniorização". Acho que esse é o mal do século. As pessoas estão saindo muito cedo da faculdade, estão indo muito rapidamente para o MBA, para a Pós e estão perdendo uma coisa que é a experiência, a sensibilidade, a flexibilidade, a capacidade de opinar baseada em vivência profissional e com a marca. O que deve ocorrer é as pessoas avaliarem através de suas próprias visões, afinal, o trabalho é para a empresa, para a marca, para o CNPJ e não para o CPF.

\section{Gustavo Piqueira}

Eu acho que a avaliação de design ainda é muito subjetiva, é discutível. Os critérios se misturam entre pessoais e profissionais, dependendo da experiência do profissional. Mas duas coisas são fundamentais no processo de avaliação: que o feedback venha diretamente da pessoa que fez a avaliação, para que haja diálogo e discussão técnica e que o design seja avaliado em função do objetivo colocado no brief - se o objetivo for ser uma cópia da marca líder, o design da embalagem tem que atender.

\section{f) Quem julga o design de embalagens? Deve-se validar o design} desenvolvido através de pesquisas com o consumidor? 


\section{Conclusões gerais}

Quem normalmente aprova o design de embalagens é a área de marketing, mas muitas empresas acabam utilizando pesquisas com o consumidor para tomar decisões, enquanto que a pesquisa deveria ser utilizada para enriquecer o processo de desenvolvimento. Validar designs a partir de pesquisas com consumidor não é recomendável, visto que podem surgir vieses de interpretação - seja porque o consumidor é influenciado pelo grupo, seja porque não teve tempo de interagir com a proposta ou porque prefere as soluções que the parecem mais familiares, mais comuns.

\section{Alessandra Baroni}

A aprovação final deveria ser dada pela área de marketing, preferencialmente por alguém que tenha participado de todo o processo de briefing e de criação. Se não for possível, é importante que o aprovador esteja alinhado com o profissional que gerenciou todas as atividades para evitar desgastes no processo.

A validação junto ao consumidor depende da estratégia da marca. Acredito que validação, via pesquisa, deva ser utilizada quando há uma preocupação em não perder share, em manter seus consumidores, em não gerar polêmica. Mas se a estratégia pretendida é uma grande virada de marca e o conceito é muito inovador, o consumidor pode avaliar negativamente o design porque não the é familiar, porque está fora de sua área de conforto.

Logo, a pesquisa deve ser um meio, não um fim. Deve ser utilizada para compreensão e não para tomada de decisão. O objetivo da pesquisa é dar inputs no desenvolvimento, devendo ser feita no meio ou o início do processo de desenvolvimento. Nunca no final. Mas, $100 \%$ das empresas tomam decisão com base em pesquisa qualitativa. 


\section{Ricardo Arantes}

Respondido na questão anterior.

\section{Sergio Guardado}

O responsável pela aprovação deve ser um profissional de marketing. Acredito que boa parte desses profissionais já tem critérios muito sensatos com relação à avaliação de design. Entretanto, ainda é um processo muito entremeado com o desenvolvimento pessoal e é impossível separar o gosto pessoal das coisas.

Validação através de pesquisa com consumidor definitivamente é um tema dramático. Não se pode passar a decisão para o consumidor como se fosse concurso de beleza. A avaliação de design através de uma pesquisa pode resultar em uma simulação equivocada. As pessoas necessitam de tempo para se envolver com aquela idéia para poder avaliá-la coerentemente. Além disso, há uma influência muito grande do grupo nas opiniões pessoas, o que normalmente cria vieses na pesquisa. É necessário simular a convivência, deixar o consumidor perceber, interagir e avaliar o objeto de design com maior profundidade atenuando os defeitos da discussão em grupo. Se você quiser medir a pertinência do conceito gráfico com as pessoas, você deve evitar a interferência de terceiros e favorecer a convivência para ter um resultado mais confiável.

\section{Zeuner Fraissat}

Pesquisa com o consumidor é importante para dar inputs antes da embalagem estar pronta, porque o consumidor não é técnico. A pesquisa simula um espaço super recortado da realidade aonde as pessoas não são $100 \%$ autênticas, elas atuam muitas vezes pois sabem que estão sendo gravadas, respondem de acordo com a condução da 
mediadora... Eu não acho que tenha verdade, que tenha valor na decisão. O ideal é ter coragem para colocar na embalagem o que realmente você realmente acredita, ter certeza ou estar convencido de que todos os atributos da tua marca estão representados naquelas cores, naquela tipologia, naquele desenho e ter isso compartilhado com área criativa e com a área de planejamento, como todo o time envolvido. Acho que os profissionais devem conhecer tão bem o consumidor a ponto de não precisar que ele diga que está bom. Pesquisa tem que ser feita o tempo inteiro, para inovar, para dar inputs, para que a marca possa criar algo para o consumidor que ele jamais sonhou que ia precisar.

\section{Gustavo Piqueira}

O problema da pesquisa é que os resultados, muitas vezes, acabam sendo "tomados ao pé da letra" - se deu na pesquisa é isso que o consumidor quer. A impressão que tenho em pesquisa qualitativa de embalagens é de que o consumidor, em geral, é avesso a coisas muito diferentes. $O$ consumidor se assusta muito na hora, o que não quer dizer que isso não possa ser construído e lançado. Não sou contra a pesquisa, mas acho que, às vezes, existe um exagero em não questionar os resultados.

DESIGN DE EMBALAGENS - POTENCIALIDADES E FUTURO.

g) Quais os principais desafios para o Design de embalagens e tendências futuras?

\section{Conclusões gerais:}

O grande desafio da embalagem é difundir sua importância e estimular investimentos, especialmente no design estrutural. Como 
tendências, os profissionais apontam: embalagens ecologicamente corretas, mais envolventes e cativantes, que simplifiquem, via tecnologia, a vida dos usuários; embalagens virtuais.

\section{Alessandra Baroni}

O grande desafio é fazer com que a embalagem seja vista como uma verdadeira peça de comunicação, recebendo a devida importância e atenção que merece. Além disso, é importante desenvolver o design estrutural, que ainda está começando no Brasil, visto que implica em investimentos. Na Europa é impossível resistir às embalagens de água, mesmo tendo filtro de água em casa. Você se depara com a embalagem de Evian e acredita que aquela água vai te transformar na pessoa mais pura do mundo. O dia que uma categoria tão commodity como água fizer um consumidor sonhar aqui no Brasil, acho que teremos vencido um desafio de mostrar que uma embalagem pode fazer toda a diferença.

\section{Ricardo Arantes}

Acredito que o design de embalagens ainda tem muito a desenvolver, principalmente no que diz respeito a criar embalagens mais eficientes e ecologicamente corretas; prolongar a interação com o consumidor, do ponto de venda para uma maior participação na vida das pessoas; embalagens menores, mas muito mais ricas em mensagens da marca, mais eficientes como mídias, mais envolventes e cativantes; embalagens mais inteligentes: com custos menores, tamanhos mais adequados, materiais ecologicamente corretos, mais emocionais e funcionais.

\section{Sergio Guardado}

Eu acho que a grande ameaça para o design de embalagem ou 
talvez o grande modificador da relação é a Internet. Todo design de embalagem se baseia numa coisa só - no auto-serviço que, aos poucos, está migrando pra Internet. Outro desafio é o design estrutural. Ele precisa se repensar, de uma maneira muito mais radical; os tipos de embalagens, as tecnologias, os formatos. $E$ a questão de conscientização ecológica. O lixo que a embalagem produz, o poder reciclável, o desperdício de material.

\section{Gustavo Piqueira}

Espero que comecem a aparecer coisas mais break through. $\mathrm{O}$ mercado precisa desenvolver mais a avaliação estética. 


\section{Conclusões}

Mais do que um instrumento de comercialização de produtos, as embalagens sempre desempenharam, em maior ou em menor nível, uma função comunicativa a serviço da marca e dos consumidores.

Até 1950 as embalagens detinham, de modo geral, um caráter de proteção e de identificação do produto, sendo responsáveis por proteger o conteúdo bem como identificar o fabricante, fornecendo informações mínimas sobre sua procedência. Alguns fabricantes, vislumbrando um futuro não tão distante, já utilizavam a embalagem para, mais que identificar, refletir os atributos e benefícios do produto, prática que viria a se consolidar com o advento do auto-serviço, onde a embalagem passaria a desempenhar a função de vendedor silencioso.

Informação, conservação, uso ergonômico, apelo, promoção e transmissão do posicionamento foram algumas das funções que as embalagens passaram a contemplar a partir de 1950.

Influenciadas pelo rápido desenvolvimento dos supermercados, pelo advento da TV bem como pelas crises econômicas, as embalagens driblaram acontecimentos, evoluíram, se reinventaram e hoje, na era das marcas fortes, constituem uma grande oportunidade de comunicação e construção de valor para as marcas, afinal, a concorrência demonstra-se cada vez mais acirrada, o consumidor cada vez mais exigente e a mídia tradicional cada vez mais diluída e cara.

Seu maior desafio, na atualidade, reside em edificar uma roupagem exclusiva e de propriedade da marca, um design que promova uma diferença tangível frente aos concorrentes e que se comunique de maneira poderosa com o consumidor alvo. As empresas que se conscientizarem dessa oportunidade, terão em mãos uma poderosa, acessível e efetiva ferramenta de comunicação de marca, com a qual poderão garantir uma real vantagem competitiva. 
Isso porque a embalagem é capaz de criar associações para marca o tempo todo: seja quando exposta no ponto de venda, seja na interação junto ao consumidor, seja durante o uso, ou quando armazenada no lar. Associações essas que se revertem para a marca através da viabilização da venda ou do fortalecimento do Equity.

Fortalecer o Equity demanda um trabalho consistente e de longo prazo, apoiado na construção de conhecimento de marca, na criação de significado e relevância através de um posicionamento exclusivo, na criação de imagem, reações e sentimentos favoráveis à marca bem como no fortalecimento do relacionamento junto ao consumidor.

O design pode influenciar cada uma dessas etapas através do uso de recursos visuais que façam da embalagem um elemento de identidade e de comunicação memorável, exclusivo, favorável e estético, promovendo, assim, a produção de mensagens visuais com o propósito de afetar a percepção, a atitude e o comportamento das pessoas em prol da marca.

A embalagem pode tornar uma marca conhecida; pode estimular sua experimentação através da comunicação persuasiva de atributos e benefícios do produto, pode contribuir na diferenciação da marca, reforçar a percepção de qualidade do produto, pode gerar identificação junto ao público alvo através da expressão da personalidade da marca, facilitar o uso, propiciar novas e prazerosas experiências de consumo, estimular a empatia e o relacionamento junto ao consumidor e até mesmo influenciar na lealdade de marca.

Mas as embalagens só são capazes de desempenhar esse papel se seu caráter comunicativo for devidamente manipulado, se forem geridas como elemento de informação, persuasão e de formação de imagem, dentro de uma mentalidade de gestão estratégica de design, cujo foco deverá ser a inserção da embalagem no programa de planejamento da marca, definindo-a como um diferenciador essencial da 
mesma.

Quando o design de embalagens é parte do programa de planejamento, todos os seus esforços e atividades estão focados no processo de materialização da estratégia da marca e no objetivo comum de fornecer um mix exclusivo de valor, tanto para a empresa quanto para o cliente, seja através da consistência entre a solução gráficoformal da embalagem e a identidade da marca; da consistência entre a solução gráfico-formal da embalagem e a estratégia de negócios ou da coerência entre solução gráfico-formal da embalagem e o posicionamento do produto.

Logo, o sucesso de uma política de gestão estratégica de design de embalagens implica no gerenciamento da pesquisa, do planejamento, da organização, da avaliação e da comunicação visual de informações com o intuito de criar significado e ressonância para a marca, de modo que o design de embalagens se traduz, em sentido lato, em design de informação.

É partir dessa visão de processo que o design ganha um escopo, uma função ampliada, não se restringindo somente ao processo criativo dentro da agência ou do departamento de design. $O$ design passa a desempenhar um papel de mediador entre as funções de marketing ligadas ao desenvolvimento de embalagens, sendo, nesse contexto, plenamente afetado não somente pela qualidade da delimitação da problemática, materializada no brief, mas também pela qualidade de avaliação, que vai determinar sua implementação. O design começa, portanto, com o processo de planejamento da marca e termina em uma avaliação que deve ir além de requisitos estéticos; o design de embalagens começa e termina no marketing e se expressa por meio da comunicação visual.

Nesse sentido, tanto a imagem do designer quanto a do profissional de marketing ganham novas dimensões. O designer, mais 
do que talento artístico deve ser capaz de compreender as abordagens de marketing, transformando as informações mercadológicas, marcárias, técnicas e orçamentárias do brief em design de embalagens, em design de informação; já o profissional de marketing também detém responsabilidade sobre o resultado do design, devendo ser capaz de desenvolver um brief de qualidade, de fornecer as informações relevantes ao designer e de proceder a uma análise focada e objetiva, baseada no atendimento do brief e excluída de subjetivismos, tornando o processo avaliativo, mais concreto e sustentado.

Assim, "Gestão estratégica do design de embalagens: A comunicação visual a serviço da marca" resgata a importância do design de embalagens como mídia fundamental na comunicação de marca, explora suas potencialidades e limites a partir de uma abordagem estratégica, onde o design ganha um escopo de atuação ampliado não restrito à manipulação de recursos visuais, a uma função exclusiva do designer ou ao senso estético do profissional de marketing, mas a uma única atividade que implica na gestão de informações que se materializam sob a forma de uma solução visual com o intuito de criar significado e ressonância para a marca. 


\section{Referências Bibliográficas}

AAKER, David. Marcas: Brand Equity Gerenciando o Valor da Marca. 10. ed. São Paulo: Elsevier Editora, 1998.

ARNHEIM, Rudolf. Arte e percepção visual: Uma psicologia da visão criadora. São Paulo: Pioneira Thomson Learning, 2005.

BAXTER, Mike. Projeto de Produto: Guia Prático para o desenvolvimento de novos produtos. São Paulo: Editora Edgard Blucher, 1998.

BLESSA, Regina. Merchandising no Ponto de Venda. 3. ed. São Paulo: Atlas, 2005.

BONSIEPE, Gui. Design: do material ao digital. Florianópolis: FIESC/IEL, 1997.

CASTRO, Virgínia. Visão Sistêmica da Embalagem de Alimento no Processo de Comunicação: um estudo exploratório sobre a visão empresarial e a do consumidor. São Paulo, 1994. Originalmente apresentada como dissertação de mestrado, Universidade de São Paulo, FEA/USP.

CAVALCANTI, Pedro. História da Embalagem no Brasil. São Paulo: Grifo Projetos Históricos e Editoriais, 2006.

CHETOCHINE, Georges. A Derrota das Marcas: Como evitá-las. São Paulo: Makron Books, 1999.

CINQUENTA ANOS DE SUPERMERCADO NO BRASIL. Fundação Abras. São Paulo: Informe Comunicação, 2002.

COSTA, Joan. Imagem Global: Evolucion Del Diseño de Identidad. 3. ed. Barcelona: Grupo Editorial Ceac, 1994.

DONDIS, Donis. A Sintaxe da Linguagem Visual. 4. ed. São Paulo: Martins Fontes, 2003. 
DORMER, Peter. Design since 1945. New York: Thames and Hudson, 1993.

ELLWOOD, lain. O livro Essencial das Marcas. São Paulo: Clio Editora, 2004.

EXAME. Prestação de contas na embalagem. São Paulo: Ed. Abril, 16 mar. 2007.

FRASCARA, Jorge. Diseño Gráfico y Comunicación. Buenos Aires: Infinito, 2000.

Diseño Gráfico para la gente. Buenos Aires:

Infinito, 2004.

GESSY Lever: História e histórias de intimidade com o consumidor brasileiro. São Paulo: Unilever, 2001.

GOBÉ, Marc. A Emoção das Marcas. Rio de Janeiro: Editora Campus, 2002.

GOMES FILHO, João. Gestalt do objeto: Sistema de leitura visual da forma. 5. ed. São Paulo: Escrituras Editora, 2003.

HESKETT, John. Desenho Industrial. Rio de Janeiro: José Olympio, 1997.

KAPFERER, Jean-Noël. As marcas, capital da empresa: Criar e Desenvolver marcas fortes. 3. ed. São Paulo: Artmed Editora, 2003.

KELLER, Kevin Lane. Strategic Brand Management: Building, Measuring and Managing Brand Equity. 2. ed. New Jersey: Prentice Hall, 2003.

KOTLER, Philip. Administração de Marketing. 10. ed. São Paulo: Prentice Hall, 2000.

. Marketing para o Século XXI: Como criar, conquistar e dominar mercados. São Paulo: Futura, 1999. 
LENCASTRE, Paulo de. Gestão de Marca. São Paulo, 2004. Seminário apresentado à Escola de Comunicação e Artes/USP, CD-ROM.

LEWIS, David; BRIDGES, Darren. A Alma do Novo Consumidor. São Paulo: Makron Books, 2004.

LIDWELL, Willian; HOLDEN, Kitrina; BUTLER, Jill. Universal Principles of Design. Massachusetts: Rockport Publishers, 2003.

LOJACONO Gabriella; ZACCAI, Gianfranco. Dossiê Design. HSM Management, São Paulo. Disponível em: <http://www.hsmmanagement.com.br>. Acesso em: jan-2006.

KLIMCHUCK, Marianne Rosner; KRASOVEC, Sandra A. Packaging Design: successful product branding from concept to shelf. New Jersey: John Wiley \& Sons Inc., 2006.

MACHADO, Marcos. Curso de Branding. abr/06. Apostila oferecida pela Associação brasileira de Anunciantes, 2006.

MARTINS, J. R; BLECHER, Nelson. O Império das Marcas: Como Alavancar o Maior Patrimônio da Economia Global. 2. ed. São Paulo: Negócio Editora, 1997.

MATTAR, Fauze Najib; SANTOS, Dílson Gabriel dos. Gerência de Produtos: Como tornar seu produto em sucesso. 2. ed. São Paulo: Atlas, 2003.

MESTRINER, Fábio. Design de Embalagens: Curso Avançado. 2. ed. São Paulo: Prentice Hall, 2005.

MEYERS, Herbert; GERSTMAN, Richard. The visionary Package: Using pachage to build effective brands. New York: Palgrave Macmillan, 2005.

MOLES. Abraham; COSTA, Joan. Publicidad y Diseño. Buenos Aires: Ediciones Infinito, 1999.

MORAES, Regina Lucia de Oliveira. Interfaces Humano Computador, 
2006. CD-ROM.

MORRIS, Charles. Fundamentos de la teoría de los signos. Buenos Aires: Editorial Paidós, 1985.

MOZOTA, Brigitte Borja de. Design management: Using design to build brand value and corporate innovation. New York: Allworth Press, 2003.

MUNARI, Bruno. Design e Comunicação Visual. Rio de Janeiro: Edições 70, 1968.

NARITA \& ASSOCIADOS DESIGN: Case Bubbaloo. 1 folder

NEUMEIER, Marty. The brand gap: How to Bridge the Distance Between Business Strategy and Design. United States of América: New Riders Publishing, 2003.

NORMAN, Donald A: Emotional Design: Why we love (or hate) everyday things. England: Basic Books, 2004.

OLHAR 100\% DESIGN: Perfil Estratégico: Case Torradas Bauducco. 1 folder.

PANIZZA, Janaína. Metodologia e o processo criativo em projetos de comunicação visual. São Paulo, 2004. Originalmente apresentada como dissertação de mestrado, Universidade de São Paulo, ECA/USP.

PEREZ, Clotilde. Signos da Marca: Expressividade e Sensorialidade. São Paulo: Pioneira Thomson Learning, 2004.

PETERS, Tom. Design: Innovate, Differentiate, Communicate. New York: DK Publishing, 2005.

PETERS, Tom. O circulo da Inovação. São Paulo: Harbra, 1998.

PHILLIPS, Peter L. Creating the perfect design brief: How to manage design for strategic advantage. New York: Allworth Press, 2004. 
PILDITCH, James. The silent salesman: How to develop packaging that sells. London: London Business Publications, 1961.

PROPAGANDA brasileira. ESPM. São Paulo: Referência, DVD.

REX DESIGN. Guia Prático: Case Omo. 2P. 1 folder

RIES, All; RIES, Laura. The 22 Immutable Laws of Branding. New York: Collins, 2002.

SAMARA, Beatriz Santos. Pesquisa de Marketing: Conceitos e Metodologia. 2. ed. São Paulo: Makron Books, 1997.

SAMARA, Beatriz Santos; MORSCH, Marco Aurélio. Comportamento do Consumidor: Conceitos e Casos. São Paulo: Prentice Hall, 2005.

SANTAELLA, Lucia. Semiótica Aplicada. São Paulo: Pioneira Thomson Learning, 2004.

SCHMITT, Bernd; SIMONSON, Alex. A Estética do Marketing. São Paulo: Nobel, 2002.

SOUZA, Sandra M. R. Souza de. Do conceito à imagem: Fundamentos do Design de Pictogramas. São Paulo, 1992. Originalmente apresentada como tese de doutorado, Universidade de São Paulo, ECA/USP.

\section{Design marketing Comunicação:}

particularidades e interseções. Revista Eca, $n^{\circ} 30$, p. 40-49, jan-abr. 1997.

Pictogramas: Imagens falantes.

Revista ADG - Revista da Associação dos Designers Gráficos do Brasil, $n^{\circ} 23$, p.30-33, out, 2001.

STREHLAU, Vivian lara. A embalagem e sua Influência na Imagem do Produto. São Paulo, 1996. Originalmente apresentada como dissertação de mestrado, Universidade de São Paulo.

STREHLAU, Vivian lara; BACHA, Maria de Lourdes. Design e 
Marketing. Revista da ESPM, São Paulo, p. 38-45, jul-ago, 2005.

SWAN, Allam. Design e Marketing. Oxford: Phaidon Press, 1990.

TAMBINI, Michael. O design do Século. São Paulo: Editora Ática, 1996.

THE POWER of packaging: brand disposition from pre-store to instor. Disponivel em <http://www.nielsen.com/consumer insight>. Acesso em: 03/12/2007.

THOMPSON, John B. A mídia e a modernidade: uma teoria social da mídia. Petrópolis: Vozes, 1998.

UNILEVER effective packaging. Apostila oferecida pela The Unilever Projects Group \& The Added value Company. Westerham Press Limited. St. Ives plc.

VÁSQUEZ, Ruth Peralta. Comunicação de Marca: Aportes da Publicidade Impressa na Comunicação da Identidade da Marca. São Paulo, 2006. Originalmente apresentada como dissertação de mestrado, Universidade de São Paulo, ECA/USP.

VENDRAMINI, Luiz Carlos. A influência da Embalagem e o Comportamento do Consumidor: aspectos e considerações do marketing e merchandising em ação. São Paulo, 1987. Originalmente apresentada como dissertação de mestrado, Universidade de São Paulo, ECA/USP.

WHITE, Alex W. The elements of graphic design. New York: Allworth Press, 2002.

WILLIAMS, Robin. Design para quem não é designer: Noções básicas de Planejamento Visual. 2. ed. São Paulo: Callis Editora, 2005.

WOODHAM, Jonathan M. Twentieth-Century Design. New Yok: Oxford University Press, 1997.

YANAZE, Mitsuro H. Gestão de marketing e comunicação: avanços e aplicações. São Paulo: Saraiva, 2007. 


\section{Indice de Figuras}

\begin{tabular}{|c|c|c|c|}
\hline Figura 1 & Sabonete Gessy & p. 15 & $\begin{array}{l}\text { Gessy Lever: História e Histórias de } \\
\text { Intimidade com o Consumidor Brasileiro }\end{array}$ \\
\hline Figura 2 & Anúncio Creme Dentral Gessy & p. 16 & $\begin{array}{l}\text { Gessy Lever: História e Histórias de } \\
\text { Intimidade com o Consumidor Brasileiro }\end{array}$ \\
\hline Figura 3 & Anúncios Sabonetes Gessy & p. 17 & $\begin{array}{l}\text { Gessy Lever: História e Histórias de } \\
\text { Intimidade com o Consumidor Brasileiro }\end{array}$ \\
\hline Figura 4 & Anúncios Sabonetes Lever & p. 18 & $\begin{array}{l}\text { Gessy Lever: História e Histórias de } \\
\text { Intimidade com o Consumidor Brasileiro }\end{array}$ \\
\hline Figura 5 & Sabonete Lever & p. 19 & $\begin{array}{l}\text { Gessy Lever: História e Histórias de } \\
\text { Intimidade com o Consumidor Brasileiro }\end{array}$ \\
\hline Figura 6 & Sabonete Ivorey Soap & p. 19 & O Design do Século \\
\hline Figura 7 & $\begin{array}{l}\text { Embalagens e Anúncios do } \\
\text { Sabonte Gessy }\end{array}$ & p. 20 & $\begin{array}{l}\text { Gessy Lever: História e Histórias de } \\
\text { Intimidade com o Consumidor Brasileiro }\end{array}$ \\
\hline Figura 8 & $\begin{array}{l}\text { Nova embalagem do Sabonete e } \\
\text { Creme Dental Gessy }\end{array}$ & p. 21 & $\begin{array}{l}\text { Gessy Lever: História e Histórias de } \\
\text { Intimidade com o Consumidor Brasileiro }\end{array}$ \\
\hline Figura 9 & $\begin{array}{l}\text { Chegada dos Supermercados ao } \\
\text { Brasil }\end{array}$ & p. 23 & 50 Anos de Supermercados no Brasil \\
\hline Figura 10 & Linha de Beleza Gessy & p. 24 & $\begin{array}{l}\text { Gessy Lever: História e Histórias de } \\
\text { Intimidade com o Consumidor Brasileiro }\end{array}$ \\
\hline Figura 11 & $\begin{array}{l}\text { Embalagem Display Sabonete } \\
\text { Lever }\end{array}$ & p. 24 & $\begin{array}{l}\text { Gessy Lever: História e Histórias de } \\
\text { Intimidade com o Consumidor Brasileiro }\end{array}$ \\
\hline Figura 12 & Creme Dental Pepsodent & p. 25 & 50 Anos de Supermercados no Brasil \\
\hline Figura 13 & $\begin{array}{l}\text { Embalagens Detergente em Pó } \\
\text { Rinso e Tide }\end{array}$ & p. 26 & O Design do Século \\
\hline Figura 14 & $\begin{array}{l}\text { Nova Tecnologia na Embalagem } \\
\text { Lever }\end{array}$ & p. 27 & $\begin{array}{l}\text { Gessy Lever: História e Histórias de } \\
\text { Intimidade com o Consumidor Brasileiro }\end{array}$ \\
\hline Figura 15 & $\begin{array}{l}\text { Anúncio e Embalagem Xampu } \\
\text { Seda }\end{array}$ & p. 30 & $\begin{array}{l}\text { Gessy Lever: História e Histórias de } \\
\text { Intimidade com o Consumidor Brasileiro }\end{array}$ \\
\hline Figura 16 & Linha de Xampu Seda & p. 32 & $\begin{array}{l}\text { Gessy Lever: História e Histórias de } \\
\text { Intimidade com o Consumidor Brasileiro }\end{array}$ \\
\hline Figura 17 & Embalagens Marcas Próprias & p. 34 & 50 Anos de Supermercados no Brasil \\
\hline Figura 17 & Linha Pão de Açucar & p. 34 & www.paodeacucar.com.br \\
\hline Figura 18 & Funções das Embalagens & p. 43 & Autoria própria \\
\hline Figura 19 & Formatos de Embalagem & p. 44 & Imagens da autora \\
\hline Figura 20 & Embalagem Vanish & p. 45 & Imagens da autora \\
\hline Figura 21 & Embalagem Pato Purific & p. 45 & Imagens da autora \\
\hline Figura 22 & $\begin{array}{l}\text { Snack Elma Chips - Sabores da } \\
\text { Terra }\end{array}$ & p. 46 & Imagens da autora \\
\hline Figura 23 & Ação Hellmann's & p. 47 & Imagens da autora \\
\hline Figura 24 & Linha de Águas Ouro Fino & p. 48 & $\underline{\text { www.aguasourofino.com.br }}$ \\
\hline Figura 25 & Embalagens Rexona & p. 49 & $\underline{\text { www.rexona.com.br }}$ \\
\hline Figura 26 & Edição Especial de Embalagens & p. 49 & www.evian.com \\
\hline
\end{tabular}


Evian

Figura 27 Snack Elma Chips - Sensações

Figura 28 Xampu Garnier Fructis

Figura 29

Embalagem de Detergente em Pó Omo

Figura 30

Identidade Visual dos Detergentes em Pó

Figura 31

Elementos de Identidade Omo e Veja

Figura 32 Embalagens Tetra Pack de Leite

Figura 33 Águas Ouro Fino

Figura 34

Indicativo de Compra Detergente em Pó Surf

Figura 35

Códigos Visuais da Catergoria de Detergente em Pó

Figura 36

Análise da Sintaxe Visual das Embalagens de Detergente em Pó

Figura 37

Análise do Posicionamento da Categoria de Xampus

Figura 38

Conceito de Seda através da Hierarquia Visual

Figura 39 Torradas Bauducco

Figura 40 Linha Knorr de Caldos

Figura 41 Leite Parmalat

Figura 42 Papel Higiênico Scott

Figura 43 Embalagem Seda Anti Spong

Figura 44 Cremes para o Corpo

Figura 45 Detergente em Pó Ala

Figura 46 Embalagens de Molho de Tomate

Figura 47 Achocolatado Taeq

Figura 48 Catchup Predilecta

Figura 49 Embalagem Detergente em Pó Surf - Contra rótulo

Figura 50 Embalagem de Limpador Multiuso

Figura 51 Instruções de Uso Surf e Omo

Figura 52 Sabonete Lux

Figura 53 Xampu L'Oreal Kids

Figura 54 Embalagem Água Plus Ouro Fino

Figura 55 Embalagem Leite de Colônia

Figura 56 Café Três Corações

Figura 57 Anúncios Desodorante Axe

Figura 58 Embalages Desodorante Axe p. 50 Imagens da autora

p. 50 Imagens da autora

p. 51 Imagens da autora

p. 53 Imagens da autora

p. 54 Imagens da autora

p. 55 Site corporativo das empresas

p. 55 www.aguasourofino.com.br

p. 59 Imagens da autora

p. 60 Imagens da autora

p. 61 Imagens da autora

p. 65 Imagens da autora

p. 68 Autoria própria

p. 69 Folder $100 \%$ Design

p. 70 Imagens da autora

p. 70 Imagens da autora

p. 71 Imagens da autora

p. 71 www.seda.com.br

p. 72 Imagens da autora

p. 73 Imagens da autora

p. 75 Imagens da autora

p. 76 Imagens da autora

p. 76 Imagens da autora

p. 77 Press Release Surf

p. 77 Imagens da autora

p. 78 Imagens da autora

p. 78 www.luxluxo.com.br

p. 79 Imagens da autora

p. 79 www.aguasourofino.com.br

p. 80 Imagens da autora

p. 80 Imagens da autora

p. 81 www.axe.com.br

p. 82 Imagens da autora 


\begin{tabular}{|c|c|c|c|}
\hline Figura 59 & Embalagens Linha Ekos Natura & p. 83 & Imagens da autora \\
\hline Figura 60 & Embalagens Roll On Rexona & p. 84 & www.rexona.com.br \\
\hline Figura 61 & $\begin{array}{l}\text { Análise de Risco do Design de } \\
\text { Embalagens }\end{array}$ & p. 86 & Autoria própria \\
\hline Figura 62 & $\begin{array}{l}\text { Percepção de Qualidade nas } \\
\text { Embalagens de Atomatados }\end{array}$ & p. 87 & Imagens da autora \\
\hline Figura 63 & $\begin{array}{l}\text { Etapas da Gestão Estratégia do } \\
\text { Design de Embalagens }\end{array}$ & p. 92 & Autoria própria \\
\hline Figura 64 & $\begin{array}{l}\text { Áreas de Interface no } \\
\text { Desenvolvimento de Embalagens }\end{array}$ & p. 93 & Autoria própria \\
\hline Figura 65 & Cadeia de Valor da Embalagem & p. 94 & Visionary Package \\
\hline Figura 66 & $\begin{array}{l}\text { Processo de Gestão Estratégica } \\
\text { do Design de Embalagens }\end{array}$ & p. 94 & Autoria própria \\
\hline Figura 67 & Função Ampliada do Design & p. 96 & Autoria própria \\
\hline Figura 68 & Significado do Brief & p. 101 & Autoria própria \\
\hline Figura 69 & $\begin{array}{l}\text { Pilares do Brief de Design de } \\
\text { Embalagens }\end{array}$ & p. 103 & Autoria própria \\
\hline Figura 70 & $\begin{array}{l}\text { Objetivos de Negócios e } \\
\text { Estratégias de Design }\end{array}$ & p. 106 & $\begin{array}{l}\text { Create de Perfect Design Brief: How to } \\
\text { manage design estrategic advantage }\end{array}$ \\
\hline Figura 71 & $\begin{array}{l}\text { Ciclo de Vida dos Produtos e o } \\
\text { Design }\end{array}$ & p. 108 & Universal principles of Design \\
\hline Figura 72 & $\begin{array}{l}\text { Influência da Embalagem na } \\
\text { Percepção de Preço-Omo }\end{array}$ & p. 111 & Imagens da autora \\
\hline Figura 73 & Tendências & p. 111 & www.trendwatching.com/trends \\
\hline Figura 74 & Território da Marca & p. 112 & Autoria própria \\
\hline Figura 75 & Painel de Embalagens - Omo & p. 119 & Folder Rex Design \\
\hline Figura 76 & Embalagem Display Bubbaloo & p. 119 & Folder Narita Design \\
\hline Figura 77 & $\begin{array}{l}\text { Check list de desenvolvimento de } \\
\text { embalagem }\end{array}$ & p. 120 & $\begin{array}{l}\text { Design de Embalagens: } \\
\text { Avançado }\end{array}$ \\
\hline Figura 78 & Tipos de Pesquisa & p. 128 & Dossiê Design - HSM Management \\
\hline Figura 79 & Dimensões do Signo Gráfico & p. 129 & $\begin{array}{l}\text { Do conceito à imagem: Fundamento do } \\
\text { Design de Pictogramas }\end{array}$ \\
\hline Figura 80 & $\begin{array}{l}\text { Roteiro para Avaliação do Design } \\
\text { de Embalagens }\end{array}$ & p. 130 & Autoria própria \\
\hline
\end{tabular}




\section{Anexos}

\section{Entrevistado: Alessandra Baroni}

Empresa: Design Absoluto

Cargo: Sócia-Diretora

\section{Você considera a embalagem uma ferramenta estratégica para a marca?}

A embalagem é uma ferramenta estratégica e esse entendimento deve aumentar. Afinal, não existe mais televisão sem controle remoto, as pessoas não querem mais ver comerciais, outdoor é sinônimo de poluição visual e a decisão de compra cada vez mais é feita no ponto de venda. Ou a embalagem fala naquela hora, ou ela não vai falar mais. Ou você impacta o consumidor naquele exato momento, que dependendo da categoria pode tomar alguns segundos, ou não vai adiantar nada a marca estar bem posicionada, ou você querer comunicar algo a mais. Esse é o caráter estratégico da embalagem. Você pode perder vendas por causa dela, ou ganhar.

Você acha que as empresas se utilizam do potencial comunicativo da embalagem gerenciando com propriedade esse elemento de identidade de marca?

A embalagem desempenha algumas funções: a primeira é o impacto, porque sem ele você não consegue comunicar nada. A segunda é a mensagem que se quer transmitir, momento em que você vai fazer o consumidor se interessar ou não por aquilo que você está comunicando Mensagem, eu não digo escrita. Mensagem visual que você está vendo lá na embalagem. A terceira é o branding, porque se isso não reverter para a marca, você não adicionou valor e também não cumpriu o objetivo total da comunicação.

Através da embalagem se comunica tudo, benefício funcional, valores emocionais, o posicionamento da marca, a personalidade: você comunica a própria marca, mesmo através de um design estrutural. Com a embalagem você constrói o Equity da marca em todos os sentidos, funcionais e emocionais.

Mas, todo esse potencial comunicativo ainda não está claro para todas as empresas. Afinal, existem muitos profissionais julgando um design pelo o que elas gostam ou o que eles não gostam. Muitas vezes os profissionais esquecem pra quem que eles estão trabalhando - o consumidor.

\section{Você acha que isso está claro para maioria das pessoas, das empresas?}

Não, nem nas grandes empresas isso não está claro. Hoje em dia eu escuto muito: "ai, eu não amei este lay out, esta embalagem. Não estou amando". Mas é pra classe C! Você não tem que amar, porque se fosse pra você, você deveria amar, mas você é classe A!. Então, existem muitos profissionais julgando um design pelo o que eles gostam ou o que eles não gostam. Muitas vezes os profissionais esquecem pra quem que eles estão trabalhando!. Se seu público é classe C, você tem que ir lá perguntar para a moça que trabalha na sua casa. Não cabe a você julgar. 


\section{E então porque você acha que isso acontece, falta de conhecimento?}

Eu acho que as pessoas esquecem pra quem que elas estão trabalhando. Por que o consumidor fica onde? Ele tem que ser o primeiro, é nele que a gente tem que pensar o tempo inteiro.

Um dia a gente estava fazendo um lay out de sabonete pra classe $C$, então pregamos todos as embalagens na parede e fomos julgar. Fizemos um julgamento de quais opções íamos levar para o cliente, o porquê e a estratégia baseada no que conhecíamos. Então chamamos uma pessoa que trabalhava aqui, que era o público alvo da marca e pedimos sua opinião. Ficamos na dúvida porque ela escolheu uma rota diferente da que acreditávamos. Aí decidimos levar o que a gente achava ideal para o cliente que teve a mesma avaliação que a nossa. Entretanto, ao levar para a pesquisa... A nossa opção não foi a escolhida. Ou seja...

\section{Qual é a importância do brief no processo de desenvolvimento de embalagem?}

O brief é que vai nortear o planejamento da marca e depois a criação. Ele é o documento com o qual confrontamos todas as artes. Ele tem que ter todas as informações relevantes à criação, bem como inspiração suficiente para colocar o cliente como top of mind na cabeça da agência. As informações não necessitam estar escritas - há marcas que nos levam à casa do consumidor, por exemplo, o que é extremamente inspirador e informativo. Ou seja, é importante ir além das palavras, passear no supermercado, discutir junto com o cliente para se obter bons resultados.

Entretanto, poucos são os profissionais que sabem da importância do brief no processo criativo. Os profissionais, especialmente os mais jovens, não tem nem experiência em desenvolvimento de embalagem e tratam a embalagem como um invólucro, e não como uma ferramenta de comunicação. É preciso profundidade, conhecimento para poder transmitir as informações de forma correta e inspiradora em um brief, bem como definir o que se quer comunicar através da embalagem. Além disso, é importante que o responsável pela aprovação esteja envolvido durante todo o processo, bem como na entrega dos trabalhos criativos, propiciando um maior alinhamento entre os envolvidos.

\section{E, normalmente, como vem um brief para vocês?}

Muitas vezes vem por telefone, ou, então, em um documento escrito só pra constar. Mas a reunião de briefing é mais importante, porque é de lá que tiramos inspiração. Eu acho que escrever faz parte, mas não adianta mandar por e-mail sem conversar. Depois será preciso investir mais tempo para retrabalhar.

\section{Existe uma metodologia projetual para o design de embalagens?}

A metodologia é a seguinte: recebemos o brief do cliente. A área de planejamento pesquisa tendências, competidores, outras categorias, até encontrar um ou mais temas para a criação. A partir disso, criamos alguns conceitos de comunicação. Discutimos os conceitos com a área de criação que começa a trabalhar no desenvolvimento. Além disso, acreditamos que deve haver uma informação privilegiada na embalagem, de modo que seja mais fácil para o consumidor 
compreender a mensagem. Então, criamos três embalagens, dentro do mesmo tema, que comuniquem, por exemplo, três diferentes mensagens e apresentamos para o cliente.

Apresentamos três opções porque acreditamos que é o número ideal. Apresentar "cinqüenta" lay outs significa que você tem um problema de julgamento interno e que quer repassar o trabalho para o cliente. Criamos várias rotas, mas o filtro é ter mais ou menos três.

\section{Como se avalia o design de uma embalagem? Quais os critérios considerados?}

O mais importante é que o cliente avalie o conceito criativo apresentado e escolha um dos conceitos para que a agência possa, a partir daí, determinar o detalhamento estético e técnico. $O$ objetivo é ter, primeiramente, o conceito de comunicação aprovado junto ao cliente, e não a embalagem como um todo, ou sair com o conceito de comunicação reprovado sabendo o que tem que ser feito. Muitas vezes o conceito é aprovado de primeira, só que a embalagem só vai ser totalmente definida um mês depois porque é necessário avaliar a cor do fundo, a área de código de barras, se está adequada à faca, etc. Assim, da primeira reunião, o que tem que voltar é uma retro-alimentação conceitual para refinar o nosso trabalho.

Os critérios de avaliação devem estar relacionados ao brief e ao público alvo, centrando-se em questões conceituais e não em questões de linguagem: a linguagem deve estar a cargo da agência que entende tecnicamente de estética, de linguagem e comunicação gráfica. A agência é que deve recomendar qual a melhor forma de comunicar aquilo que o cliente aprovou enquanto conceito de comunicação. Além disso, os profissionais não podem esquecer, durante a avaliação, para quem eles estão trabalhando.

\section{Quem julga ou aprova o design de embalagens?}

A aprovação final deveria ser dada pela área de marketing, preferencialmente por alguém que tenha participado de todo o processo de briefing e de criação. Se não for possível, é importante que o aprovador esteja alinhado com o profissional que gerenciou todas as atividades para evitar desgastes no processo. Muitas vezes levamos todo o processo com um gerente de produto e na hora que chega um diretor de marketing para a reunião de apresentação, você vê que eles não estão alinhados...

\section{Você acha que o consumidor sempre tem que dar o aval final sobre o design da embalagem através de pesquisas?}

A validação junto ao consumidor depende da estratégia da marca. Acredito que validação, via pesquisa, deva ser utilizada quando há uma preocupação em não perder share, em manter seus consumidores, em não gerar polêmica. Mas se a estratégia pretendida é uma grande virada de marca e o conceito é muito inovador, o consumidor pode avaliar negativamente o design porque não lhe é familiar, porque está fora de sua área de conforto. Logo, quando há ruído para o consumidor, significa que você está mudando alguma coisa naquela categoria, e não que aquele novo design não foi bem recebido. Mas isso é lido pelas empresas de maneira inversa: causou ruído, está reprovado. Será que não é hora de causar ruído? Será que não é hora de sair da área 
de conforto?

Logo, a pesquisa deve ser um meio, não um fim. Deve ser utilizada para compreensão e não para tomada de decisão. O objetivo da pesquisa é dar inputs no desenvolvimento, devendo ser feita no meio ou o início do processo de desenvolvimento. Nunca no final. Mas $100 \%$ das empresas tomam decisão com base em pesquisa qualitativa porque as pessoas se sentem mais confortáveis com o endosso do consumidor.

Então, para nós a pesquisa é frustrante por mais que eu entenda que existem horas em que a pesquisa é necessária para, por exemplo, verificar se eu não vou perder os meus consumidores. Marcas líderes não podem arriscar. O que está bem estabelecido está bem estabelecido em termos de negócio. Mas se você quer inovar, chamar a atenção e se destacar no mercado, às vezes é melhor não ter pesquisa.

Você acha que o mesmo tratamento que é dado pro desenvolvimento de embalagem é dado por exemplo a uma campanha na TV?

Não, para a TV é mais "glamuroso". As pessoas aparecem mais, é mais caro. Se o design de embalagens no Brasil fosse tão caro como é na Europa, talvez as pessoas valorizassem mais o design de embalagens. Mas, como é uma coisa corriqueira, e empresas ainda não perceberam a força que as embalagens têm, o processo acaba sendo conduzido por profissionais juniores e o patamar de qualidade fica baixo.

\section{A embalagem tem a capacidade de envolver o consumidor além de chamar a atenção e trabalhar a visibilidade?}

Em algumas categorias é possível, mas acredito que mais do que envolver, a embalagem deve convidar o consumidor a experimentar, a pegar, a olhar. Ser inviting. Envolvimento é difícil com uma peça de comunicação tão rápida como a embalagem.

\section{Quais os desafios e potencialidades do design de embalagens?}

O grande desafio é fazer com que a embalagem seja vista como uma verdadeira peça de comunicação, recebendo a devida importância e atenção que merece. Além disso, é importante desenvolver o design estrutural, que ainda está começando no Brasil, visto que implica em investimentos. Na Europa, é impossível resistir às embalagens de água, mesmo tendo filtro de água em casa. Você se depara com a embalagem de Evian e acredita que aquela água vai te transformar na pessoa mais pura do mundo. O dia que uma categoria tão commodity como água fizer um consumidor sonhar aqui no Brasil, acho que teremos vencido um desafio de mostrar que uma embalagem pode fazer toda a diferença. 


\section{Entrevistado: Gustavo Piqueira}

Empresa: Rex Design

Cargo: Sócio- Diretor

\section{Você acredita que a embalagem constitui um elemento estratégico da marca?}

Sim. Afinal, o que fazemos é construir identidades. A nossa expertise não é saber os macetes de sabonete, por exemplo, mas sim construir identidade, levando em consideração a personalidade e os valores daquele objeto, seja ele qual for, o mercado que ele está inserido e como ele deve pertencer aquele mercado.

Criar uma comunicação entre o objeto e o receptor, na medida em que tentamos definir como vai se dar esta comunicação entre o objeto e o receptor, reflete um processo estratégico, um pensamento estratégico. Em alguns casos, por exemplo, como capa de um livro, normalmente muito subjetivo, temos uma casca que envolve um conteúdo, que vai estar exposta em um ponto de venda, a embalagem e o conteúdo têm raciocínios diferentes, mas quando você consegue juntar o raciocínio dos dois é sempre mais produtivo para reflexão, porque senão você pode acabar caindo em vícios específicos de cada mercado.

A embalagem é uma ferramenta estratégica, afinal, a detém uma função na identidade primeira do objeto. Porque por mais que você tenha uma campanha, por mais que você tenha outras estratégias de comunicação, a embalagem é o meio de comunicação inevitável. Ela pode até não ser a peça mais importante no seu plano de comunicação, mas ela é inevitável. Se você erra num filme, você pode torcer para que metade do público não assista, se você erra na embalagem, todo todos vêem.

Você acha que as empresas se utilizam integralmente do potencial comunicativo da embalagem e gerenciam corretamente esse elemento de identidade?

A noção da embalagem como um elemento estratégico e não como material de ponto de venda é algo que ainda está surgindo, se consolidando.

Reconheço que melhorou muito, tanto é que surgiram dezenas de empresas de design de embalagens mas, ainda tem muita empresa em que o trabalho é ruim, o que é sinal de que a questão de embalagem ainda não está super amadurecida. Existe um nível de competência e não excelência.

Ainda existem muitos vícios, como os códigos de categoria, que ninguém sabe onde e porque começou, mas é uma mecânica usual - você é obrigado a fazer mesmo sem saber exatamente se isso é algo relevante para o consumidor.

Para um creme dental, por exemplo, um clássico de categoria, sempre utiliza-se a mesma diagramação: divide-se a embalagem em três, os dois terços da esquerda vão para o logo e o terço que sobra na direita para o benefício, sabor, etc. Todos têm a mesma estrutura, mas não acredito que a base disso seja algo inerente ao consumidor. Imagino que foi se estabelecendo a partir da marca líder, que foi ditando o comportamento dos concorrentes, e fazendo o consumidor se acostumar, até chegar a um ponto que isso não mudou mais, virando uma verdade natural, 
originando os vícios de cada categoria.

Quanto maior a estrutura de uma empresa, maiores são os vícios. Infelizmente vejo que em muitos projetos que faço, os resultados acabam se diluindo nos códigos de categoria, virando quase um design genérico.

Outro vício é envolver o designer somente em algumas etapas do projeto. Em alguns, o envolvimento inicia antes da solução gráfica - em geral estes se saem melhor - em outros, o envolvimento inicia-se apenas no final, como uma espécie de decorador, nestes é mais fácil que as coisas se diluam.

E ainda há o vício da pesquisa. A atuação do designer fica limitada, muito em razão das pesquisas, pois, em muitos casos, a pesquisa é "tomada ao pé da letra": se saiu na pesquisa é porque o consumidor quer.

\section{Qual a importância do brief? Existe um formato ideal? Quem deve estar envolvido no processo?}

Um bom brief é um panorama geral do produto e do ambiente no qual este se insere: objetivos claros e bem definidos.

É muito comum encontrar nos briefs, como objetivo, ter impacto e tornar a marca mais moderna. Mas o que é ser moderno, afinal? Impacto também é algo muito associado à visibilidade no ponto de venda, quando deveria ser considerado em um sentido mais amplo, como chamar a atenção de alguém por algum motivo relevante, sem necessariamente ter que gritar. O impacto é um dos vícios dos briefs, ainda que a percepção do produto no ponto de venda seja algo importante.

Ou seja, muitos profissionais não sabem muito bem o que exatamente necessitam, não sabem o que pedir para o designer. Logo, é fundamental saber identificar quais são os dados relevantes para aquele projeto de design e saber transmití-los ao designer. Não basta dizer que a embalagem tem que ter impacto ou outras obviedades.

\section{Existe algum método processual que vocês usam ou que seja ideal usar?}

Você tem que ter métodos criativos diferentes para cada projeto. Para definição do método é necessário ter um estudo do entorno: avaliar o público, a concorrência e o ambiente, e priorizar com diferentes pesos. Isso porque cada projeto tem seus elementos-chave, suas variáveis, como o público, o produto, o objeto, aonde ele vai aparecer, quem são os competidores e como se relacionam com esse produto ou marca.

\section{Como você avalia um design de embalagem? Que critérios devem ser levados em consideração?}

Eu acho que a avaliação de design ainda é muito subjetiva é discutível. Os critérios se misturam entre pessoais e profissionais, dependendo da experiência do profissional. Mas duas coisas são fundamentais no processo de avaliação: que o feedback venha diretamente da pessoa que fez a avaliação, para que haja diálogo e discussão técnica, e que o design seja avaliado em função do objetivo colocado no brief - se o objetivo for ser uma cópia da marca líder, o design da 
embalagem tem que atender. Além disso, acho que existe uma avaliação estética e que para o pessoal de marketing não faz a menor importância. Eu sinto que os profissionais de marketing são bem capacitados, mas existem exceções.

\section{Quem aprova o design de embalagens? Deve-se avaliá-lo através de pesquisas junto ao consumidor?}

O problema da pesquisa é que os resultados, muitas vezes, acabam sendo "tomados ao pé da letra" - se deu na pesquisa é isso que o consumidor quer. A impressão que tenho em pesquisa qualitativa de embalagens é de que o consumidor, em geral, é avesso a coisas muito diferentes. O consumidor se assusta muito na hora, o que não quer dizer que isso não possa ser construído e lançado. Não sou contra a pesquisa, mas acho que, às vezes, existe um exagero em não questionar os resultados.

\section{O que você vê de potencialidade para design de embalagens e futuras tendências?}

Eu espero que aqui pelo menos, comecem a aparecer coisas mais bacanas e coisas pequenas mais break through. Eu acho que o mercado precisa passar a avaliar melhor, os dois níveis de avaliação, a estética e mercadológica. Os dois são importantes. Mas é pela estética que você consegue evoluir para outros patamares. O mercado precisa desenvolver mais a avaliação estética. O design não é nem mercado, nem estética. Espero que isso aconteça, começando do menor fazendo coisas bacanas. O design viveu nos últimos dez anos um boom e eu acho que esse boom é bom, porque popularizou o termo, mas todo mundo fala, mas não sabe muito o que fazer e não tem muito como avaliar. 


\section{Entrevistado: Ricardo Arantes}

Empresa: Unilever do Brasil

Cargo: Gerente global de inovação para a categoria de cuidados com o lar da Unilever

\section{Você considera a embalagem uma ferramenta estratégica da marca?}

Sim porque ela consegue transmitir os valores da marca e gerar diferenciação no ponto de venda, onde, para a categoria de produtos de limpeza, acontecem as principais decisões. Trata-se de uma forte ferramenta de diferenciação e conquista do consumidor, visto que transmite os principais elementos de satisfação com o produto, seus atributos e benefícios, auxiliando na tarefa de posicionamento da oferta. Além disso, contribui para o negócio tanto estrategicamente, auxiliando na construção do Equity da marca, quanto no curto prazo, auxiliando nas vendas.

Você acha que as empresas se utilizam integralmente do potencial comunicativo da embalagem gerenciando com propriedade esse elemento de identidade de marca?

A embalagem é uma mídia visto que interage com o consumidor, transmitindo informações e mensagens. Embora a embalagem ainda não tenha alcançado o destaque que mereça dentro das organizações e, conseqüentemente, no mix de marketing e no mix de meios de comunicação, a tendência é que a embalagem ganhe cada vez mais espaço. Hoje a similaridade entre marcas $\mathrm{e}$ produtos é muito grande e a decisão de compra se faz cada vez mais no ponto de venda, onde a embalagem é o meio mais eficaz de gerar diferenciação para o consumidor. É nesse sentido também que o design ganha importância, promovendo diferenciação e visibilidade para a marca. A maioria das empresas exploram muito pouco esta importante ferramenta da marca. $\mathrm{O}$ trabalho acaba sendo muito limitado, já que é visto como um custo adicional. Em outros mercados como na Europa e no Japão, o potencial comunicativo da embalagem é amplamente explorado, configurando uma mentalidade muito mais desenvolvida. Algumas empresas até têm consciência da importância da embalagem na comunicação de marca, mas ainda têm uma visão extremamente voltada para custos e lucratividade no curto prazo. Isso acontece porque partem de uma cultura, de uma visão estritamente "financeira" do negócio, e não uma visão de marca, uma visão holística do consumidor. Logo, não possuem e não buscam desenvolver habilidades técnicas para o gerenciamento do design de embalagens, visto que não é foco de atenção. Poucas são as empresas que empregam designers, e, quando sim, o foco de suas atividades e ações está mais concentrado nas atribuições de resistência e proteção da embalagem. Para um gerenciamento ideal, deveriam ser criados times multifuncionais com profissionais de Design e Marketing liderando o tema - isso certamente faria toda a diferença.

\section{Existe, na sua empresa, um método projetual definido para o design de embalagens?}

Hoje não há um processo definido, mas estamos trabalhando para isso. $O$ time de Marketing desenvolve o brief juntamente com a área técnica de P\&D-Packaging, responsável pelas questões de viabilidade, e apresenta para a agência de design de embalagem. 
Qual a importância do brief no design de embalagens? Existe um formato Ideal? Quem deve estar envolvido nesse processo?

O brief é de fundamental importância porque dá a direção para o resultado gráfico esperado. Tendo a dizer que responsabilidade pelo resultado é dividida $50 \%$ em função da qualidade do brief e $50 \%$ em função da qualidade técnico e criativa do designer. O formato ideal de brief seria: resumo sobre a marca, seus valores; resumo sobre o público alvo e o que este valoriza; atributos e benefícios do produto que a embalagem quer transmitir; objetivos. O brief deve ser desenvolvido por marketing com o suporte da área técnica de embalagens e da área interna de design, se houver. $O$ importante é que as pessoas que estejam envolvidas no processo de briefing e, posteriormente, de criação, tenham um profundo conhecimento da marca, do consumidor, das implicações técnico-produtivas bem como um perfil criativo.

\section{Como se avalia o design de uma embalagem? Quais critérios devem ser avaliados?}

Para avaliar o design de embalagem, são levados em consideração os seguintes critérios: alinhamento com o brief, aspectos estéticos, aspectos técnicos e funcionais, entendimento do consumidor. Sempre que possível buscamos validar a embalagem com o consumidor mas, durante o processo ou mesmo quando não é possível submetê-la ao público alvo, buscamos "enxergar" a embalagem do ponto de vista do consumidor para um melhor julgamento. A avaliação, entretanto, é muito subjetiva, uma questão intuitiva como a maioria das avaliações de conceito e comunicação de marca.

Já a validação é feita conjuntamente entre a área de marketing e de pesquisa e desenvolvimento, considerando os resultados de pesquisa junto ao consumidor.

Quem julga o design de embalagens? Deve-se validar o design desenvolvido através de pesquisas com o consumidor?

Conforme item anterior.

\section{Quais os principais desafios e tendências para o Design de embalagens?}

Acredito que o design de embalagens ainda tem muito a desenvolver, principalmente no que diz respeito a criar embalagens mais eficientes e ecologicamente corretas; prolongar a interação com o consumidor, do ponto de venda para uma maior participação na vida das pessoas; embalagens menores mas muito mais ricas em mensagens da marca, mais eficientes como mídias, mais envolventes e cativantes; embalagens mais inteligentes: com custos menores, tamanhos mais adequados, materiais ecologicamente corretos, mais emocionais e funcionais. 


\section{Entrevistado: Sergio Guardado}

\section{Empresa: Seragini Farne Guardado Design}

\section{Cargo: Sócio-Diretor}

\section{Você acredita que a embalagem constitui uma ferramenta estratégica da marca? Por que?}

Em muitos produtos a embalagem é a cara da marca. Se considerar o sabão em pó, a embalagem aparece mais que o próprio produto. Certos produtos são mais conhecidos pela embalagem do que pela própria essência física do produto. Seguramente a embalagem é, para muitos produtos, o grande formador da própria essência da marca. Ou seja, a construção da identidade das coisas se dá muito pela sua embalagem, principalmente produtos de consumo de supermercado. Talvez uma bicicleta não dependa muito da embalagem, mas produtos de consumo de supermercado, sem dúvida, são identificados pela embalagem, ou seja, o primeiro território privilegiado de percepção e construção de personalidade de marca é a embalagem, mais do que propaganda ou outras ferramentas, que nem todos os produtos têm. Nem todo produto tem propaganda: embalagem, no mínimo, o produto tem. Nem todos os produtos têm comunicação, nem todos têm promoção, nem todos usam largamente essas ferramentas de marketing, em resumo, a embalagem sempre estará lá. Daí ser valor estratégico.

\section{Você acredita que as embalagens contribuem para compor o Equity da marca?}

O Equity de Coca-Cola, por exemplo, está muito centrado na forma, que é um property da marca. O amarelo de Bombril, o raio de Nescau são sinais que incorporaram significado à essência da marca, à sua natureza e, ao mesmo tempo, criaram diferenciadores e identificadores fantásticos numa situação de confronto visual. Você consegue isso com cor, a cor de Sonho de Valsa, a cor de Milka, você consegue através de elementos cromáticos, através de formas, através de personagens. Existem elementos diferenciadores fundamentais cuja embalagem é o grande suporte visível. O que constrói a personalidade de uma marca? Propaganda? Sim, mas definitivamente na embalagem, a identidade última do produto, aquela coisa que você pega e compra e leva para casa - identidade mais nuclear do produto está naquela embalagem. A embalagem é o núcleo final da experiência do produto.

\section{As empresas têm consciência da importância estratégica da embalagem?}

As empresas cada vez mais estão se convencendo da importância estratégica da embalagem. A Seragini existe há 26 anos, e se compararmos os anos $80 \mathrm{com}$ os dias atuais, vamos ver que tudo era muito diferente. Existia uma idéia da embalagem como uma espécie de adereço cosmético e inútil, uma certa visão puramente estética, de um complemento decorativo e secundário, supérfluo. Hoje qualquer profissional de marketing sabe que se a embalagem dele for ruim, a chance dele vender menos é muito alta. Hoje é voz corrente que se você não prestar atenção na embalagem, você perde dinheiro. Mas, ainda é possível melhorar muita coisa. Consciência da importância já existe, o que ainda não existe é instrumentação inteligente desta consciência. 


\section{As empresas se utilizam plenamente do potencial comunicativo da embalagem?}

Não. Acho que tem um equívoco muito grande no Brasil. No ano passado, eu fui num supermercado da Inglaterra e fiquei olhando uma série de categorias de produtos. Cada salgadinho, por exemplo, tem uma personalidade de marca. Um tem uma cena de deserto, outro tem uma moça, o outro tem uma cena de consumo, o outro tem uma cena abstrata. Cada produto constrói sua personalidade em cima de um motivo, de um tema. No Brasil, copia-se o que o líder faz.

No Brasil existe a idéia de que se o líder construiu uma certa notoriedade em função de alguns sinais gráficos, todo mundo, bem ou mal, necessita usurpar um pouco dessa propriedade que a marca original criou. Isso é um equívoco muito grande e o potencial comunicativo da embalagem acaba sendo subutilizado. Acho que ainda falta uma postura mais empreendedora. Acho ainda falta, nas empresas, a ousadia de entender que, se uma marca se estabeleceu com uma certa linguagem, você pode buscar outros temas relativos àquele produto, outras facetas do imaginário ligado a aquele produto. Alguém colocou pudim de leite condensado na embalagem de leite condensado e todos repetem a mesma fórmula. Deve ter alguma outra utilização para esse produto que ainda não foi explorada! Ou seja, existe uma certa mediocridade de todo mundo querer ser mediano, de todo mundo querer ser meio previsível, para que não seja preciso arriscar e o mercado acaba se "comoditizando".

\section{A embalagem traz resultados reais para o negócio? Como é possível mensurá-los?}

Nós fizemos uma mudança de Toddy nos anos 90, que rendeu um crescimento de quatro ou cindo pontos na participação de mercado apenas com uma mudança na embalagem. Você tem

centenas de exemplo assim, principalmente de marcas que estão no segmento de notoriedade média. Não sei se melhorar a embalagem de Dove, uma marca consagrada, aumentará as vendas, mas se você fizer uma embalagem terrível, ou deixar de atualizá-la ao longo dos anos, provavelmente você perderá participação de mercado.

Em contrapartida, para certas marcas mais intermediárias e de participação menos hegemônicas do que Dove, sem dúvida alterar a embalagem faz uma diferença brutal, até porque, apesar de tudo, ainda existe muita embalagem equivocada no mercado.

Existe um certo despreparo com relação à organização dos elementos da embalagem, resultando em dificuldade de compreensão. Quando o nosso olho não entende as coisas, quando capta uma síntese errada, você rejeita. Você interpreta e interage bem com aquilo que você entende.

\section{Muitas empresas acreditam que uma boa embalagem é aquela que tem um alto impacto ou visibilidade no ponto de venda. $O$ que você acha disso?}

A idéia de você sobrepor o impacto aos outros elementos que constroem uma boa embalagem, foi uma coisa muito marcante nos anos 90. A embalagem tem um certo poder de chamar a atenção e explicar pra que serve e construir personalidade de marca. Isso acontece em um cenário multi-povoado por outras embalagens, aonde é preciso construir seu espaço de 
percepção na gôndola.

O que o consumidor ganha com uma embalagem bem resolvida do ponto de vista funcional e gráfico?

A primeira coisa que a embalagem tem que fazer pelo consumidor, do ponto de vista do uso, é ser ergonômica e proteger bem o produto. Embalagem vende uma vez só! Se a embalagem for ruim e não proteger, não adianta. A outra, é propiciar, na medida do possível, prazer na compra e no consumo. Nós temos prazer em conviver com marcas. Todos nós temos, desenvolvemos uma relação de recompensa com os produtos e é aí que a embalagem pode agregar valor.

Acho que o papel sutilíssimo, mas muito nobre da embalagem é entender onde que está essa recompensa, que a pessoa espera encontrar, quando ela compra sucrilhos. Entender e fazer com que essa experiência de comprar e consumir sucrilhos seja gostosa. O design da embalagem ajuda o consumidor a se reencontrar com o seu desejo.

\section{Como é a metodologia projetual para o design de embalagens?}

O primeiro passo é entender o brief que o cliente apresentou e isso envolve pesquisa e planejamento. Então, traçamos um mapa de onde estamos e aonde pretendemos chegar. A primeira ação concreta é o trabalho de pesquisa que pode envolver uma relação direta com o consumidor, uma discussão em grupo, uma pesquisa na Internet, uma entrevista por telefone, visitar o ponto de venda, avaliar a concorrência, até a criação de uma primeira plataforma estratégica. A partir daí, inicia-se um processo de brainstorming, seguido da criação de conceitos que vão para as mãos de um ou mais designers. Ao desenvolver as primeiras embalagens, realizamos um check-list estratégico para avaliar se o design responde às necessidades mercadológicas apresentadas no brief, e um check-list técnico, para ver se o design é viável. Se o design for internamente aprovado, montamos uma apresentação detalhando todo o processo de desenvolvimento. Depois da apresentação, segue o processo de refinamento conceitual e estético e a etapa de finalização.

Qual a importância do brief no design de embalagens? Existe uma formato ideal? Quem está envolvido no processo?

Quando eu comecei a trabalhar, o brief era uma verdadeira divindade diante do projeto no qual ele girava. Hoje, o cliente apresenta o produto, o problema e uma questão pra você resolver. $\mathrm{O}$ brief, nas empresas de ponta, é, hoje, um estímulo para um designer que detém uma postura muito mais estratégica e questionadora. Questionadora não no sentido de contrapor-se ao brief, mas no sentido de crescer, de colocar-se no lugar da verdadeira divindade que é o consumidor. Acho que, atualmente, há um deslocamento de uma soberania absoluta do cliente-brief, para uma negociação entre esses três atores. Isso porque o designer cresceu como interlocutor, deixando de ser um desenhista executador de serviços para ser um interlocutor de Branding.

Mas, nem todas as empresas são de ponta e, nesse contexto, acredito que o brief piorou, por dois motivos: primeiro porque os profissionais de marketing envolvidos no brief de embalagem são 
mais "juniores" e, segundo, porque aumentaram as condições de pressão de resultado. Aí vem o papel também de um designer experiente de também relativizar essa situação.

O cenário competitivo é muito mais complexo, então, o nível de não saber coisas e tentar descobrir junto, aumentou muito. Então eu diria o seguinte: o fato de o brief deixar de ser soberano, é porque piorou de qualidade. Espera-se mais que o designer preencha os buracos disso, o que eu acho saudável, até porque se o designer não for capaz de preencher esses buracos, ele vira desenhista. $\mathrm{E}$ a diferença entre o desenhista e o designer é que ele consegue entender... aquela história que o Bob Lew fala que, para o designer o problema é "o problema' e fala assim: a diferença do designer e o publicitário é que quando você contrata o publicitário você espera que a resposta do seu problema esteja na barriga dele, no talento criativo do publicitário, e quando você contrata um designer você tem que esperar que a resposta do seu problema esteja no seu problema e que o papel do designer é ajudar a encontrar essa resposta.

A realidade é muito mais complexa, então num negócio como o brief, todas essas grandes formas lisas, elas racharam um pouco. Então, o brief vem, mas você precisa repensar o brief.

\section{0 que tem que ter no brief?}

Minimamente, o brief deveria estabelecer o que o cliente quer e porquê. E a partir disso, é necessário avaliar com quem você quer falar, qual seu perfil, qual sua demanda simbólica, quais as principais dinâmicas da categoria desse produto, quais são as alternativas de consumo àquele produto e qual a história dessa marca. A rigor, quanto mais informação, melhor. Além disso, é importante também que sejam informados no brief os pré-requisitos técnicos que viabilizam o lançamento da embalagem.

\section{Como se avalia o design de embalagens? Que critérios são levados em consideração?}

A avaliação de design ainda é muito irregular. Há profissionais que fazem avaliações estratégicas, assim como há profissionais que julgam baseados em critérios pessoais. As pessoas esquecem que aquela embalagem deve agradar ao consumidor, que normalmente tem um gosto específico, freqüenta lugares específicos e tem necessidades específicas, distintas das do cliente. Com honrosas exceções, normalmente o processo de avaliação é melhor nas grandes empresas, mas, de modo geral, trata-se de critérios subjetivos. O que temos feito para minimizar esse problema é referendar o projeto diretamente com o público alvo.

\section{Quem deveria julgar ou aprovar o design?}

O responsável pela aprovação deve ser um profissional de marketing. Acredito que boa parte desses profissionais já têm critérios muito sensatos com relação à avaliação de design. Entretanto, ainda é um processo muito entremeado com o desenvolvimento pessoal e é impossível separar o gosto pessoal das coisas.

\section{O design deve ser validado junto ao consumidor através de pesquisa?}

Validação através de pesquisa com consumidor definitivamente é um tema dramático. Não se 
pode passar a decisão para o consumidor como se fosse concurso de beleza. A avaliação de design através de uma pesquisa pode resultar em uma simulação equivocada. As pessoas necessitam de tempo para se envolver com aquela idéia para poder avaliá-la coerentemente. Além disso, há uma influência muito grande do grupo nas opiniões pessoas, o que normalmente cria vieses na pesquisa. É necessário simular a convivência, deixar o consumidor perceber, interagir e avaliar o objeto de design com maior profundidade, atenuando os defeitos da discussão em grupo. Se você quiser medir a pertinência do conceito gráfico com as pessoas, você deve evitar a interferência de terceiros e favorecer a convivência para ter um resultado mais confiável.

\section{Quais são os desafios para o design de embalagem, quais as tendências para o futuro?}

Eu acho que a grande ameaça para o design de embalagem ou talvez o grande modificador da relação é a Internet. Todo design de embalagem se baseia numa coisa só - no auto-serviço que, aos poucos, está migrando pra Internet. Como vai ser isso daqui a alguns anos? É o que temos que começar a pensar.Outro desafio é o design estrutural. Ele precisa se repensar, de uma maneira muito mais radical; os tipos de embalagens, as tecnologias, os formatos. Eu acho, que as coisas tem que ficar mais rápidas, o universo do design tem que ficar mais rico de possibilidades. Acredito também na conscientização da questão ecológica. Acho a questão da água e do biocombustível vão recolocar o Brasil dentro da discussão e a questão da embalagem vai passar por isso. O lixo que a embalagem produz, o poder reciclável, o desperdício de material. 


\section{Entrevistado: Zeuner Fraissat \\ Empresa: Design com Z \\ Cargo: Sócio- Diretor}

\section{Fale um pouco da sua experiência com a Natura em termos de design de embalagens.}

A Design com Z está há oito anos no mercado e há sete que estamos trabalhando com a Natura. Eu considero a Natura uma grande universidade, um grande centro do desenvolvimento do pensamento, e isso é instigante, é desafiador. Hoje fazemos quase $100 \%$ das embalagens que saem da Natura. Depois da Natura, passamos a mudar a forma de olhar para a embalagem. Começamos a desenvolver conceitos de linguagem de marca, isto é, como é que esta marca se posiciona, de que forma ela quer se mostrar, qual seu tom de voz. Começamos, então, a criar o que chamamos de ambiente de marca e a fazer um trabalho grande antes do desenvolvimento de embalagem, pensando como essa marca se veste, como essa marca se porta, quais são os ícones dessa marca, quais são os recursos gráficos, iconográficos, fotográficos que essa marca tem, porque a gente não tem só que pensar nos atributos que a gente quer trazer dessa marca mãe, mas também nas submarcas da Natura.

Ou seja, a Natura é pródiga nisso e a gente conseguiu nesse tempo todo contribuir bastante transformando significados em partidos gráficos, partidos cromáticos, desenhos de logotipos... Esse pensamento, antes de qualquer expressão é extremamente importante porque não só a embalagem ganha com isso, mas a marca a partir de uma coerência com o material de lançamento, com a comunicação, com a mídia, com o evento pra consultoras natura, etc. De modo que, a partir de um pensamento comum, que é o que a gente chama de linguagem, a gente começou a perceber que as coisas todas se alinhavam, apontando para uma mesma direção.

\section{Qual o papel da embalagem? Constitui uma ferramenta estratégica da marca?}

A embalagem é um ponto de contato importante para construir uma identidade de marca, não só uma identidade visual, identidade enquanto personalidade; um ponto de contato extremamente importante para levar as mensagens da marca, especialmente as que não têm mídia. Mesmo a embalagem da Natura, que se encontra em um ambiente de vendas diferente, aonde o concorrente não está competindo no espaço ao lado da gôndola, deve levar as mensagens da marca, chegar no consumidor final e resistir aos ruídos de comunicação gerados pela venda direta, contando a história daquela marca e daquele produto para o consumidor. Não que a embalagem consiga dizer tudo, mas ela tem que ser um parágrafo de um texto de marca formado por várias outras coisas. A marca deveria falar com o consumidor, em três parágrafos: a embalagem, a mídia de massa e o relacionamento.

O design de embalagens estava de costas para marca e de frente para o consumidor na gôndola, porém ainda muito centrado na comunicação dos benefícios, das habilidades do produto e em responder à briefs que pediam para "saltar da gôndola", para destacar a marca - a cultura dos splashes, extremamente americana. Acho que mais saudável a linha de pensamento europeu de 
design, mais preocupada com o conceitual.

Acho que as pessoas cada vez mais vão se importar menos com os números de opções de produto na gôndola e mais com a marca, no sentido de quem está por traz da marca, o que essa marca pensa, o que ela tem de afinidade comigo, o que ela vende além do beneficio do produtos. E a embalagem é extremamente importante para agregar este tipo de mensagem à marca; a embalagem é um dos elementos mais importantes na construção de um pensamento sobre a marca. A embalagem não deve focar somente em recursos pirotécnicos.

\section{Você acha que as empresas se utilizam bem do potencial comunicativo da embalagem?}

As empresas ainda estão numa cultura muito de olhar para o mercado e não a procura de inovações alinhadas com sua própria gênesis. A embalagem potencializa a comunicação quando faz parte de um todo que coincide na transmissão de um pensamento de marca. Daí sim ela convence as pessoas, porque vai além do produto, porque comunica a causa da marca, como a Natura. Não adianta só uma embalagem bonita, encantadora. Você pode até ser convencido a compra e a experimentar, mas você só vai ficar com esse produto se ele funcionar, se entregar o que prometeu - seja uma ação, um beneficio claro ou uma causa. A embalagem é importante pois encanta e motiva a compra, mas não é suficiente para fazer os consumidores permanecerem na marca, afinal, eles estão cada vez mais atrás de questões como mercados justos, biodiversidade, ecologia, de modo que a embalagem deve ser parte do programa da marca.

\section{Como você acha que as empresas deveriam gerenciar esse elemento de identidade de marca?}

Eu acho que ela tem coisas básicas que o consumidor já está se importando como o consumo, o próprio de material, e que as empresas deveriam atentar: o quanto essa embalagem tem de plástico, tem de papel demais, se isso é demais, se não podia ser menor... Então, o designer e as empresas devem se preocupar com isso, redução do material, redução do impacto ambiental dessa embalagem. Outro ponto importante é que as embalagens devem, mais do que "gritar" no ponto de venda, chamar as pessoas para perto, instigar, convidar para uma interação. Eu acho que as pessoas gostariam de ser menos bombardeadas pelas embalagens, menos açoitadas quando vão fazer compras - as embalagens e as marcas deviam cuidar para que os consumidores queiram chegar perto delas e tirá-las da gôndola, deviam cativar o consumidor a conhecer o produto. Será que eu preciso dos mesmos recursos pirotécnicos, gráficos, para contar a história daquele produto? Será que tem outra forma de contar no todo da embalagem, na composição completa, na escolha das cores, no jeito de fotografar as frutas? Será que tem outra forma de mostrar a personalidade, um jeito dialogar? As embalagens mais inteligentes dialogam com o consumidor, enquanto que as mais visuais ficam no palco, em um grande monólogo com um megafone, concorrendo com outras tantas marcas que tentam falar cada vez mais alto. Eu achei super corajosa uma embalagem de um suco que entrou no mercado que era branca, tinha 
só a metade de uma laranja na frente da embalagem. Entre todas as opções de sucos, um momento branco, de silêncio, que instigava a conhecer: quem é essa marca? Quem é essa empresa com essa coragem? Quem está por traz do nome de suco? Uma empresa corajosa que estar querendo mudar os códigos deste mercado!

\section{E os códigos de categoria esses são realmente importantes?}

Os códigos de categoria são. Há códigos que têm que ser mantidos porque embalagens de alimentos não podem ser confundidas com embalagens de cosméticos. Tem alguns códigos que eu acho que são uma questão de respeito com o consumidor. Mas o fundamental é olhar para a marca. Eu morro de inveja do designer que fez aquele suco branco, porque se ele olhasse para o consumidor ele não faria aquele em branco; provavelmente ele olhou para a marca e a marca sinalizou que estaria disposta a fazer algo diferente para essa categoria, que tinha personalidade para isso.

\section{Como deve ser o brief para você?}

Ele tem que ser fruto de uma grande conversa. Eu não acredito no brief que vem pronto e a gente já leva a embalagem pronta. Não acho que a gente faz design sozinho. Me frustro muito quando fazemos um contrato e o cliente tem uma visão de que eu tenho que dar todas as respostas. $O$ design é fruto do trabalho do cliente e do designer: precisamos nos reunir, conversar, nos aprofundar no universo dessa marca para que o trabalho valha à pena. E uma vez que o cliente me contou tudo, me deu a sua contribuição, eu, enquanto designe,r decodifico, entro na história de saber que temperatura tem isso, que cor tem isso, que signo é esse. Mas, para isso, é importante estabelecer um relacionamento, porque para mim só funciona se eu puder conhecer essa marca em profundidade. Por isso, quanto mais tempo durar esse relacionamento, melhor. Tem marca que a gente trabalha há mais de quatro anos e, por isso, vamos aprendendo a conhecer os defeitos, as virtudes, como em um casamento, só que usamos essa inteligência do relacionamento para as marcas.

\section{Como é o método de design da embalagem?}

Todo designer tem seu momento criativo, introspectivo, aonde tem que mergulhar nas informações e nas suas experiências para descobrir quais são as respostas. Depois deve haver pontos de diálogos com o cliente; não a apresentação da embalagem, mas sim um primeiro diálogo, um segundo diálogo... e, então, à medida que o design vai se materializando a gente ajusta o brief de modo a ter um alinhamento de expectativas entre ambas as partes, até chegar em uma solução que seja ideal para a marca.

Como são as avaliações de design? Existe muito subjetivismo? Que critérios devem ser levados em consideração? 
Ser subjetivo não é um problema porque não quero me relacionar com maquinas. Só as máquinas não têm atitudes próprias, não tem pensamento, não têm gosto pessoal... Só não se pode confundir isso com "juniorização". Acho que esse é o mal do século. As pessoas estão saindo muito cedo da faculdade, estão indo muito rapidamente para o MBA, para a Pós e estão perdendo uma coisa que é a experiência, a sensibilidade, a flexibilidade, a capacidade de opinar baseado em vivência profissional e com a marca. O que deve ocorrer é as pessoas avaliarem através de sua própria visão, afinal, o trabalho é para a empresa, para a marca, para o CNPJ e não para o CPF.

\section{Quem julga e aprova o design? Deve-se utilizar pesquisas com consumidor para validá-lo?}

Pesquisa com o consumidor é importante para dar inputs antes da embalagem estar pronta porque o consumidor não é técnico. A pesquisa simula um espaço super recortado da realidade aonde as pessoas não são $100 \%$ autênticas, elas atuam muitas vezes, pois sabem que estão sendo gravadas, respondem de acordo com a condução da mediadora... Eu não acho que tenha verdade, que tenha valor na decisão.

O ideal é ter coragem para colocar na embalagem o que realmente você realmente acredita, ter certeza ou estar convencido de que todos os atributos da tua marca estão representados naquelas cores, naquela tipologia, naquele desenho e ter isso compartilhado com a área criativa e com a área de planejamento, como todo o time envolvido. Acho que os profissionais devem conhecer tão bem o consumidor a ponto de não precisar que ele diga que está bom. Pesquisa tem que ser feita o tempo inteiro, para inovar, para dar inputs, para que a marca possa criar algo para o consumidor que ele jamais sonhou que ia precisar. 